\author{
Universidade de São Paulo \\ Instituto de Física
}

\title{
Uma abordagem de parâmetros da biomineralização em um sistema constituído por carbonato de cálcio
}

\author{
Silvia Maria de Paula
}

\section{Orientadora:}

Profa. Dra.Marina Amélia Pinto Viégas da Silveira Santos

Tese de doutorado apresentada ao Instituto de Física para a obtenção do título de Doutor em Ciências

\section{Banca examinadora}

Prof. Dr. Marcos Farina de Souza - UFRJ

Profa. Dra. Marilda da Cruz Fernandes - FFFCMPA

Profa. Dra. Rosângela Itri -IFUSP

Prof. Dr. Walter Maigon Pontuschka- IFUSP 
Dedico esta tese aos meus pais, que estão ao meu lado em todos os momentos e certamente sempre me acompanharão.

Aos meus queridos avós, in memoriam, pela doçura, amor e carinho que me dedicaram. 


\section{Agradecimentos}

No decorrer de meu trabalho no Laboratório de Microscopia Eletrônica tive a oportunidade de conviver com pessoas especiais, que contribuíram com o meu crescimento profissional e humano. Dentre essas pessoas, gostaria de abrir um parênteses ao querido colega Silvio L. Ferrari, in memoriam, responsável pela ampliação da maior parte das micrografias presentes nesta tese. Certamente sempre o terei em minha memória e coração.

À Prof $f^{a}$ Dra. Marina Silveira deixo o mais profundo sentimento de carinho e respeito. Sua gentileza, serenidade e ensinamentos foram importantes para a minha formação.

Ao Prof. Dr. Pedro K. Kiyohara e Prof ${ }^{a}$ Dra. Helena de Souza Santos pela utilização dos equipamentos, receptividade e por seus ensinamentos.

À querida colega Simone P. Toledo por sua paciência, disponibilidade e excelente suporte técnico.

Ao Prof. Dr. Carlos O Paiva Santos (Laboratório de Química Computacional de Análises Cristalográficas e Cristalinas, IQ-UNESP, Araraquara) pelas discussões e medidas de raios$\mathrm{X}$ feitas em seu laboratório. Certamente seu bom humor e atenção devem ser lembrados.

Aos senhores Maurício Keniti (Parque da água Branca) e Edson Marques Lopes que gentilmente forneceram os caramujos Physa utilizados como amostra nesta tese.

Ao Prof. Dr. Henrique E. Toma e Prof ${ }^{a}$ Dra. Anamaria Alexiou (Laboratório de Química Supramolecular e Nanotecnologia, IQ-USP) pela hospitalidade e utilização de equipamentos.

Ao colega Antonio Carlos Franco da Silveira (Laboratório de Cristalografia, IF-USP) pelas medidas de raios- $X$, por sua atenção e gentileza.

À Prof ${ }^{a}$ Dra. Márcia Carvalho de Abreu Fantini (Laboratório de Cristalografia, IF-USP) pelo uso dos equipamentos.

À Prof ${ }^{a}$ Dra. Mitiko Saiki (Laboratório de Análises por Ativação Neutrônica, IPEN, SP) pelos resultados das análises por ativação neutrônica.

Ao colega Isaac Jamil Sayeg (Laboratório de Microscopia Eletrônica de Varredura, IGCUSP) pelo uso dos equipamentos. 
À Prof ${ }^{a}$ Dra. Maria Terêsa M. Miranda e ao Prof. Dr. Cleber Wanderlei Liria (Laboratório de Química dos Peptídeos, IQ-USP) pelo uso dos equipamentos, pelas valiosas discussões e sugestões.

Ao amável colega Emerson Alves da Silva por sua amizade, atenção, paciência e pelas palavras de incentivo.

Às colegas Paula H. Filoy, Rita de Cássia C. Wagner e Flávia Cassiola, pelo carinho e atenção.

Ao colega Astrogildo de Carvalho Junqueira pelas discussões, atenção e coleguismo.

À Valquiria de Fátima Justo Kozievitch pelo coleguismo e simpatia.

À todas as pessoas da secretaria, da informática e da oficina mecânica, da Física Geral deste Instituto, que sempre apresentaram disponibilidade em me ajudar.

Aos membros da Comissão de Pós Graduação do IF-USP pela atenção e apoio nos assuntos burocráticos.

Ao Instituto de Física da USP, pela oportunidade de realização do curso de doutorado.

Ao CNPq (Processo 140929/2001-0) pela concessão da bolsa de doutorado e pelo apoio financeiro para a realização desta pesquisa.

Aos meus pais e irmãos pelo carinho, atenção, incentivo nos momentos mais difíceis de minha vida e por compreenderem minhas ausências. 


\section{SUMÁRIO}

Resumo

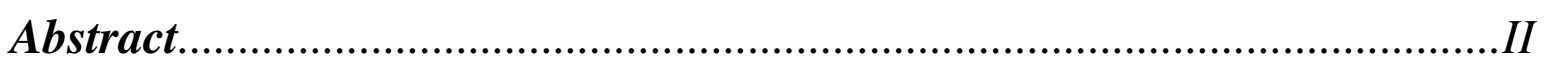

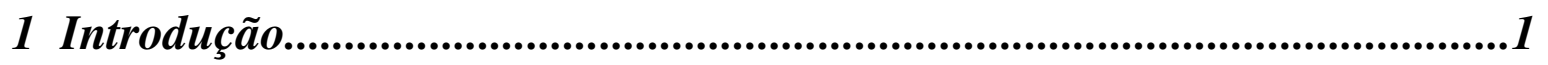

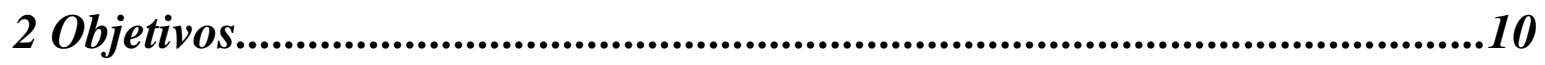

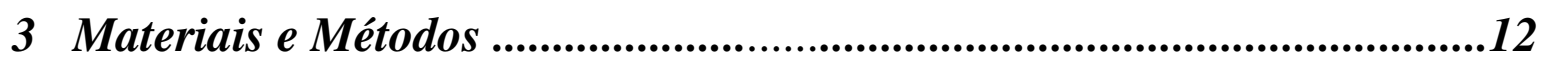

3.1 Parte I - Amostra - Physa sp. ..............................................................................................12

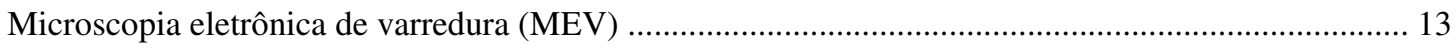

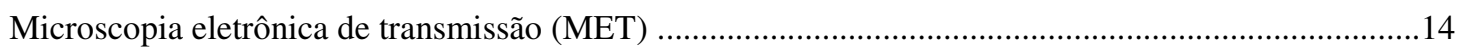

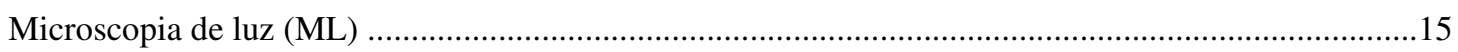

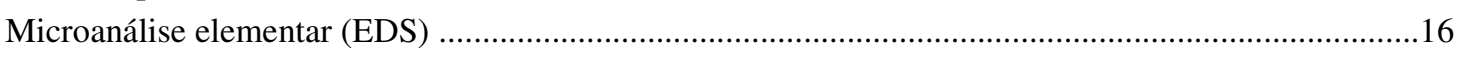

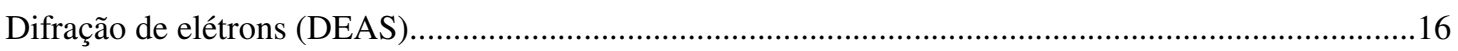

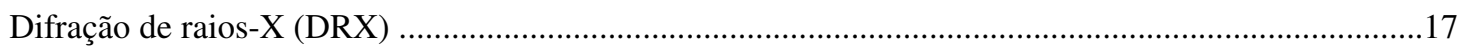

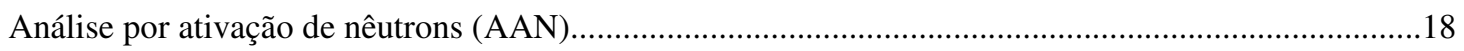

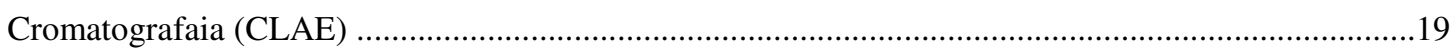

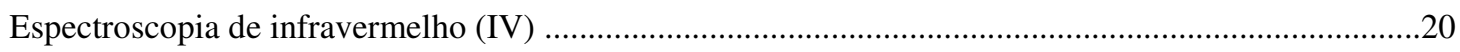

3.2 Parte II - Crescimento de cristais de $\mathrm{CaCO}_{3}$.......................................................... 21

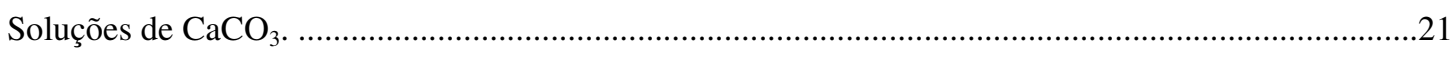

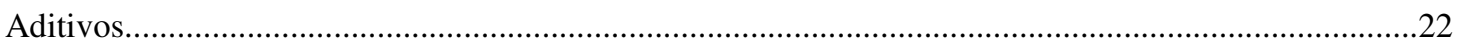

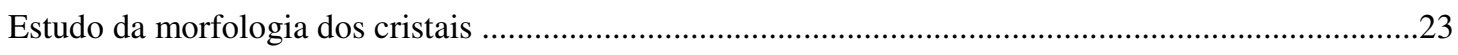

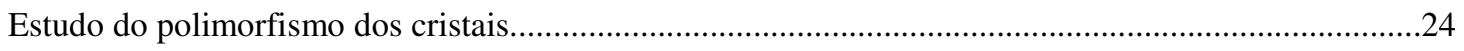




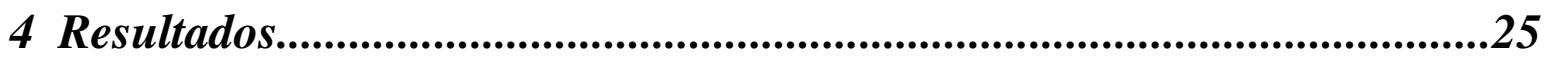

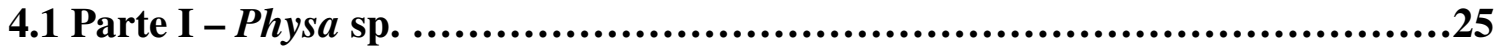

Morfologia dos componentes orgânicos e inorgânicos. .......................................................................25

Análises quantitativas e qualitativas das composições inorgânica e orgânica da concha do molusco....45

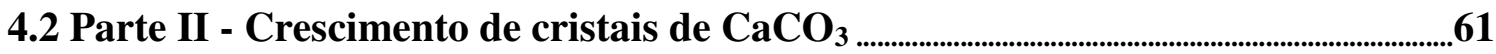

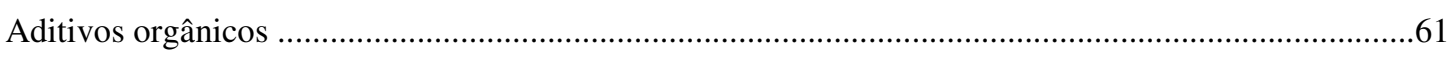

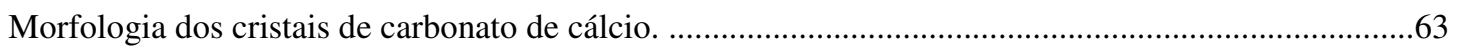

Análises quantitativas e qualitativas das fases cristalinas. .......................................................84

5 Discussão

5.1 Concha do molusco Physa sp. ...........................................................................................112

5.2 Cristalização do carbonato de cálcio. …………………………….....................................124

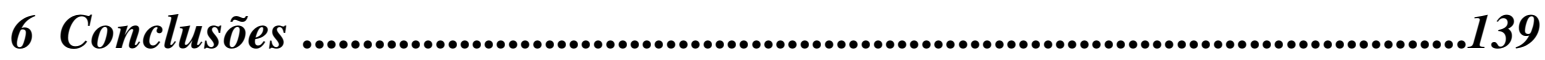

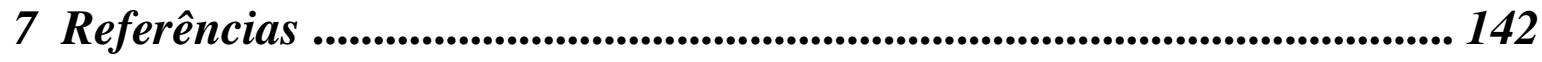

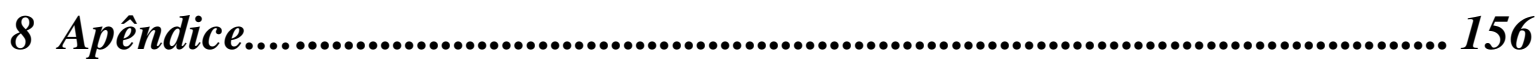




\section{RESUMO}

DE PAULA, S. M. Uma abordagem de parâmetros da biomineralização em um sistema constituído por carbonato de cálcio. 2006. Tese (Doutorado)- Instituto de Física, Universidade de São Paulo, São Paulo, 2006.

Conchas do molusco Physa sp., um gastrópode (caracol) comum de aquários de água doce, serviram como modelo para o estudo de alguns aspectos envolvidos na biomineralização. A concha calcária é constituída por cristais de carbonato de cálcio depositados em associação com uma matriz orgânica. Os componentes cristalinos e a matriz, foram estudados por microscopia eletrônica de transmissão e de varredura, e caracterizados por métodos espectroscópicos e analíticos. A constituição cristalina, em geral, assemelha-se àquela existente na maioria dos moluscos, enquanto a camada nacarada, interna da concha, apresenta comparativamente maiores variações. A matriz orgânica consta de um componente insolúvel, essencialmente constituído por polissacarídeos, enxofre e fósforo; e outro componente solúvel, com predominância de serina, glicina, ácido aspártico e ácido glutâmico. A análise feita por ativação de nêutrons demonstrou maior concentração de cálcio, sódio e estrôncio; estes elementos estão geralmente relacionados à presença de aragonita, em outras conchas de moluscos. $\mathrm{O}$ estudo qualitativo da fase cristalina foi realizado por difração eletrônica e por espectroscopia de infravermelho. Para análise quantitativa, usou-se a difração de raios-X, sendo os dados refinados pelo método de Rietveld. Os resultados obtidos demonstram a existência de dois polimorfos do carbonato de cálcio, aragonita e calcita, na concha da Physa. A caracterização qualitativa dos componentes inorgânico e orgânico do material estudado, mostrou semelhanças com relação a outros gêneros de moluscos. Experimentos de cristalização do carbonato de cálcio in vitro produziram aragonita e vaterita em presença de ácido aspártico ou glutâmico. Sob ação de glicina, serina ou quitina, houve formação de calcita. Em presença da matriz orgânica insolúvel, houve cristalização de calcita, enquanto a matriz solúvel induziu a cristalização da aragonita. Analisou-se quantitativamente todas as fases cristalinas obtidas nestes experimentos e estudou-se a morfologia dos cristais formados através da MEV e por MO luz. O resultado comparativo das investigações usando a concha natural, e dos cristais sintetizados, permitiu confirmar o papel fundamental da matriz orgânica no processo de cristalização do carbonato de cálcio.

Palavras-chave: Biomineralização. Physa sp. Carbonato de cálcio. 


\begin{abstract}
DE PAULA, S. M. Uma abordagem de parâmetros da biomineralização em um sistema constituído por carbonato de cálcio. 2006. Thesis (Doctoral)- Instituto de Física, Universidade de São Paulo, São Paulo, 2006.
\end{abstract}

Shells of Physa sp., a common freshwater gastropod snail, were used as a model for mineralization studies of calcium carbonate. The shell is a biomineral that consists of organized crystalline deposits associated to an organic matrix, both of which were studied by transmission and scanning electron microscopy; they were further characterized by means of spectroscopic and analytical methods. As a whole, its structural organization does not differ greatly from that found in other mollusc shells, except for the innermost, nacreous layer, that lines the shell. The organic matrix in Physa was found to consist of an insoluble fraction, essentially containing a polysaccharide, sulphur and phosphor. In addition, another (soluble) fraction is present, in which serine, glycine, aspartic acid and glutamic acid residues prevail. Neutronic activation analysis demonstrates a high concentration of calcium, sodium and strontium, elements known to be related to the presence of aragonite in other molluscan shells. A qualitative study of the crystalline phase was obtained through use of electron diffraction and FTIR spectroscopy. For quantitative analysis X-ray diffraction was used, as refined by the Rietveld method. Results obtained demonstrate the existence of two calcium carbonate polymorphs, aragonite and calcite in the shell of Physa, Qualitative evaluation of both organic and inorganic material from Physa showed similarities to those found in other mollusk shells. In vitro experiments performed at similar-to-natural conditions, on crystallization of calcium carbonate, did also crystallize aragonite and vaterite, provided aspartic acid or glutamic acid were present; whereas calcite was formed in solutions containing glycine, serine or chitin. Aragonite did crystallize when the soluble organic matrix was added to the solution. All these crystalline phases obtained were quantitatively evaluated, their morphologies being studied through light and electron microscopies. A comparative study of the natural crystals from the shell, and those obtained in laboratory experiments, stresses the fundamental role of the organic matrix on calcium carbonate crystallization.

Keywords: Biomineralization. Physa sp. Calcium carbonate. 


\section{Introdução}

\section{Aspectos Gerais da biomineralização}

O complexo processo que envolve a formação de cristais biogênicos tem sido estudado com crescente interesse como possibilidade de produção de novos materiais. Os biominerais são dotados de propriedades morfológicas, estruturais e mecânicas peculiares (CURREY, 1974). Tais características são manifestadas em condições ambientes de temperatura e pressão.

O estudo da biomineralização tem por objetivo central compreender a relação existente entre a matriz orgânica e o crescimento de cristais. $O$ depósito de substâncias minerais por organismos vivos envolve a nucleação e crescimento de um depósito geralmente cristalino, sob condições altamente controladas, constituindo uma interface entre macromoléculas orgânicas e íons inorgânicos.

Cerca de 60 diferentes minerais biogênicos podem ser encontrados em organismos vivos; dentre estes estão o carbonato de cálcio, os fosfatos de ferro e magnésio, os sulfatos de estrôncio, bário e potássio, citrato de cálcio, oxalatos de cobre, magnésio e cálcio (LOWENSTAM; WEINER, 1989). As bactérias, por exemplo, podem adsorver em suas paredes externas elementos como prata, ouro e urânio enquanto elementos como o bário e estrôncio são acumulados e depositados como minerais intracelulares. Outros tecidos mineralizantes como ossos, dentes, e conchas são compostos por fosfato de cálcio e minerais de carbonato, respectivamente (MANN, 1989).

As investigações sobre os aspectos que envolvem a mineralização remontam ao século 18. No século 19, a integração de pesquisadores de várias áreas do conhecimento, juntamente com o desenvolvimento de técnicas de análises químicas, de purificação e de 
métodos analíticos, aceleraram as pesquisas, trazendo novas contribuições para o preparo e análise de amostras. A matriz orgânica de ossos, por exemplo, foi descoberta por uma simples descalcificação em solução de ácido clorídrico (BOULIGAND, 2004).

Nas décadas de 60 e 70, houve um avanço no estudo da biomineralização. A aplicação das microscopias eletrônicas de varredura e transmissão proporcionaram informações sobre a microestrutura de materiais mineralizantes, encontrados em alguns animais, plantas e microorganismos (LOWENSTAM, 1981). O interesse em compreender os aspectos bioquímicos e a interação entre os componentes orgânicos e inorgânicos, acelerou as pesquisas.

Lutts, Gradjean e Grégorie (1960), investigaram por microscopia eletrônica a relação entre a microestrutura da matriz orgânica de conchiolina e a formação de prismas em conchas de moluscos. Foram analisadas dez espécies de moluscos, constatando-se que em alguns desses organismos, há fibrilas na constituição orgânica da concha. Para o conhecimento da fase cristalina, foram feitas análises por difração de raios-X, antes da descalcificação das amostras.

Aliadas às técnicas de observação por microscopia eletrônica e por microscopia de força atômica (CRUZ; WEISSMÜLLER, FARINA, 2003), incluem-se atualmente as análises por difração de raios-X, espectroscopia na região do infravermelho e cromatografia, que contribuem com informações sobre a constituição inorgânica e orgânica dos organismos estudados (BERMAN et al., 1993; BELCHER et al., 1996; AIZENBERG, et al., 1997; MARXEN; BECKER, 1997; FALINI; WEINER; ADDADI, 2003; BOSKEY, 2003). 


\section{Biomineralização em conchas de moluscos}

Dentre os vários organismos biomineralizantes, estão os moluscos pertencentes a várias classes e ordens, os quais, com grande versatilidade, produzem cerca de 26 estruturas mineralizadas e são capazes de depositar 20 minerais (SIMKISS; WILBUR, 1989). Estudos sobre o processo de formação das conchas de moluscos têm contribuído com informações sobre a relação entre a matriz orgânica, íons inorgânicos e o carbonato de cálcio.

Os moluscos possuem uma fina membrana denominada manto, que reveste a região interna da concha e limita o processo de separação das substâncias em mineral e protéica; os sais calcários são transportados à superfície do animal e as substâncias protéicas são conduzidas para os órgãos internos. Os detalhes anatômicos do manto presentes nos bivalves diferem significativamente daqueles dos gastrópodes. (LOWENSTAM; WEINER, 1989).

Entre o manto e a concha, está o fluido extrapalial; sua composição possui variações entre os moluscos, porém, de maneira geral é constituído por proteínas, glicoproteínas, carboidratos, aminoácidos, cátions $\mathrm{Na}^{+}, \mathrm{K}^{+}, \mathrm{Ca}^{2+}, \mathrm{Mg}^{2+}$ e anions $\mathrm{HCO}_{3}^{-}, \mathrm{Cl}^{-}$e $\mathrm{SO}_{4}^{2-} \cdot \mathrm{O}$ fluido possui $\mathrm{pH}$ entre 7 e 8,5, sendo responsável pela constituição química da matriz orgânica, pela taxa de crescimento dos cristais e, direta ou indiretamente, pelo polimorfismo dos cristais de carbonato de cálcio (WILBUR, 1964, TSUJII, 1980; WATABE, 1984).

Apesar de o fluido extrapalial exercer importante função no processo de cristalização do carbonato de cálcio, poucos autores investigaram sua ação (CRENSHAW, 1972; JOLLY et al., 2004; YIN et al., 2005), as pesquisas são voltadas principalmente para 
a relação entre a matriz orgânica e os componentes inorgânicos (ADDADI; WEINER, 1992; FALINI et al., 1996; FENG et al., 2000; ADDADI; WEINER; GEVA, 2001).

O processo de formação da matriz orgânica a partir do fluido extrapalial possui muitos aspectos a serem investigados; sabe-se apenas que a matriz é secretada no espaço extrapalial pelo manto, depositada em camadas na superfície interna da concha; precede portanto a formação dos cristais, sendo responsável pela orientação, nucleação e dimensão destes durante a formação da concha (WATABE, 1984; WILBUR, 1964).

A matriz orgânica é uma superfície organizada, que participa diretamente como mediadora do processo de mineralização. Nos moluscos apresenta-se dividida nas frações insolúvel e solúvel (SIMKISS, WILBUR, 1989). De acordo com ${ }^{1}$ Meenakshi et al. (1971 apud SIMKISS; WILBUIR, 1989, p. 238; WATABE, 1984, P. 462), a fração solúvel é formada principalmente por glicoproteínas, polipeptídeos e polissacarídeos. Em geral, nos moluscos, há alta concentração de resíduos dos ácidos aspártico e/ou glutâmico. A fração insolúvel é constituída por resíduos da glicina, presente em alta concentração, alanina , ácido aspártico, altas concentrações de fenil-alanina, tirosina, resíduos de grupos não polares e por conchiolina (substância rica em proteínas), originalmente caracterizada por ${ }^{2}$ Frémy (1855 apud WATABE, 1984, p 462) e analisada bioquimicamente por ${ }^{3}$ Grégorie, Duchâteau e Florkim (1956 apud MARIN; LUQUET, 2004, p. 476). A composição da fração insolúvel foi confirmada por Hare (1963).

\footnotetext{
${ }^{1}$ MEENAKSHI, V.R.; HARE, P.E., WILBUR, K. M.; Amino acids of the organic matrix of neogastropod shells. Comp. Bioch. Physiol. , v. 40B, p. 1037-1043, 1971

${ }_{2}^{2}$ FRÉMY, E. Recherches chimiques sur les os. Ann. Chem. Phys. , v. 43, p. 96, 1855.

${ }^{3}$ GREGÓIRE, C.; DUCHÂTEAU. , G.; FLORKIM, M. La trame protidique des nacre et des perles. Océanogr., Monaco, v. 31, p.1-36, 1955.
} 
A nucleação dos cristais pode ser facilitada por uma interação entre os íons minerais e as moléculas da matriz orgânica. As proteínas presentes na fração solúvel, podem inibir a cristalização, favorecendo o crescimento de um isomorfismo particular ou inibir o crescimento de certas faces cristalinas sendo possível favorecer o crescimento de um determinado cristal (HARE, 1963; WEINER, 1979; FRITZ et al., 1994).

Inúmeros autores apresentaram em seus trabalhos, a correlação entre a constituição da matriz orgânica e a cristalização da aragonita e/ou calcita (WATABE, 1960; GREGÓIRE, 1967; ALBECK et al., 1993; DAUPHIN; DENIS, 2000; FALINI et al., 2000). Wheeler, George e Evans (1981), verificaram que a adição da matriz orgânica à solução supersaturada de carbonato de cálcio inibe a formação de cristais. A adsorção da matriz orgânica em determinadas faces do cristal pode inibir completamente o seu desenvolvimento.

\section{Estrutura da concha}

A primeira concha formada pela larva dos gastrópodes corresponde ao ápice do futuro indivíduo adulto. Em continuação às voltas mais antigas e menores crescem as outras voltas, ou espiras, cada vez mais amplas, ao redor da columela, eixo central a que se vão fixando (figura 1). O animal fica preso à própria concha pelo manto e por um músculo inserido na columela e no pé.

Externamente, as conchas de moluscos são formadas por uma película de material orgânico, o perióstraco, que recobre a camada calcificada. Sua função é proteger a concha contra a corrosão que a acidez do meio pode provocar e possui importante função no depósito de cristais de carbonato de cálcio. É uma estrutura simples, mas de acordo com a 
espécie, existem variações estruturais significativas, como por exemplo, diferenças no número de camadas (SALEUDDIN; PETIT, 1983; WATABE, 1984; CHECA, 2000).

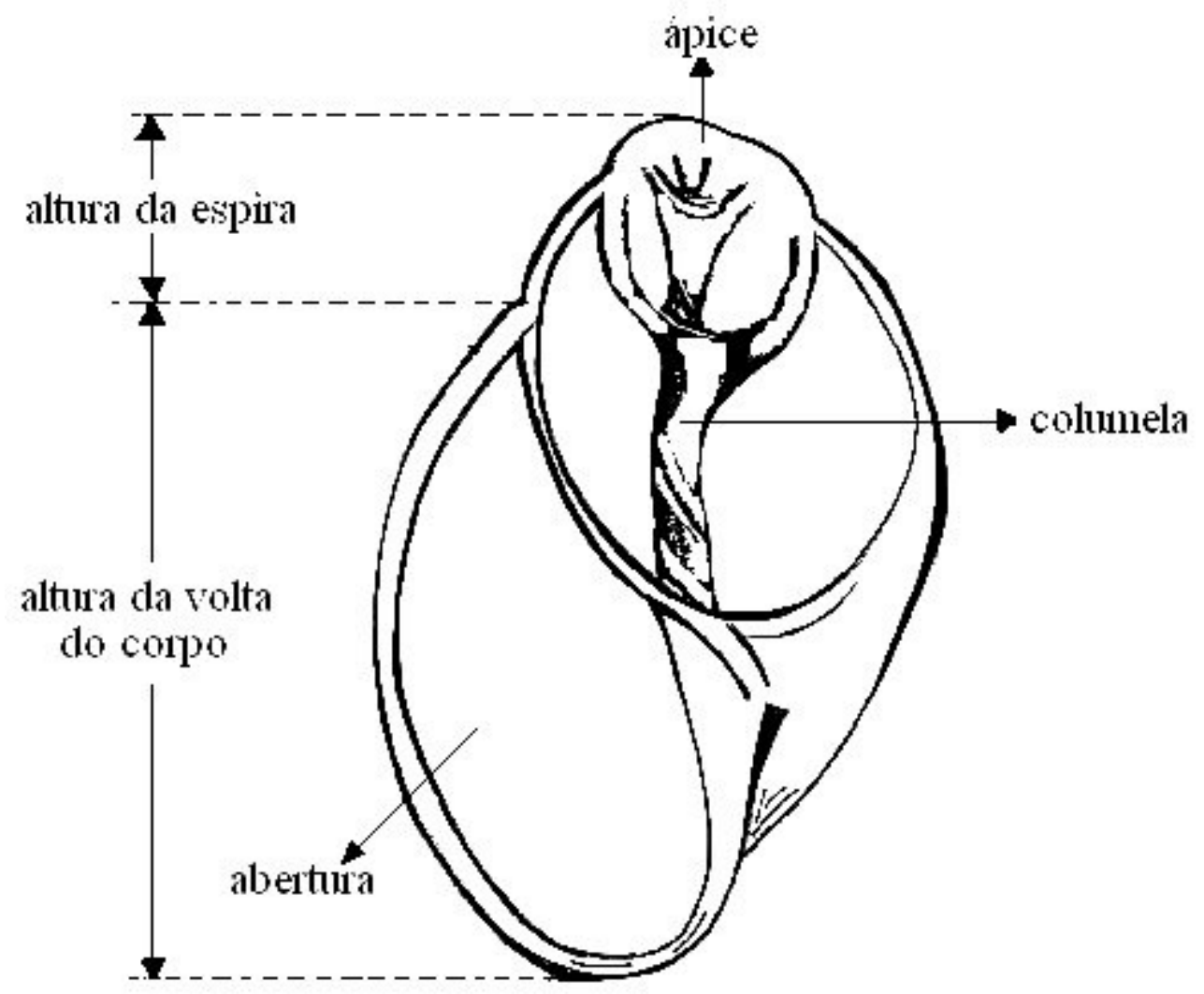

Figura 1 - Corte esquemático vertical da concha do molusco Physa sp

O perióstraco é constituído principalmente pelo aminoácido DOPA (dihidroxifenilalanina), proteínas e pouca quantidade de quitina (SALEUDDIN; PETIT, 1983; LOWENSTAM; WEINER, 1989). Apesar de sua natureza orgânica, em algumas espécies de moluscos foram encontrados ferro, cádmio (WATABE, 1984) e carbonato de cálcio (SALEUDDIN; PETIT, 1983).

Logo abaixo do perióstraco, inicia-se a camada calcificada, constituída por $90 \%$ de carbonato de cálcio e $10 \%$ de diferentes elementos inorgânicos, entre os quais, temos o 
magnésio, o estrôncio e o sódio. Pesquisas indicam que os íons inorgânicos, adicionados à solução de carbonato de cálcio, podem induzir a formação da aragonita, calcita ou vaterita (MEYER, 1984; REDDY; WANG, 1980; HAN; AIZENBERG, 2003; MAI et al., 2003; MELDRUM, 2003).

A estrutura e a organização dos depósitos cristalinos em conchas de moluscos, apresenta grande variabilidade. Esses arranjos podem ser agrupados em três categorias gerais:

- camada nacarada: é composta por agregados de placas de aragonita, depositados em lâminas ou colunas (WILBUR; SALEUDDIN, 1983).

- camada prismática : inicia-se logo abaixo do perióstraco (TEVESZ; CARTER, 1980). Dependendo da espécie de molusco, pode ser constituída por cristais de calcita ou aragonita. Possui orientação relativamente uniforme, porém, cada espécie de concha possui característica particular (SIMKISS, WILBUR, 1989).

- camada lamelar: o seu processo de formação não é claro; essa estrutura é localizada em contato com a camada prismática. É constituída por placas (SIMKISS, WILBUR, 1989).

Todas as formas cristalinas acima descritas, possuem intima relação com o depósito de material orgânico, os cristais desenvolvem-se mediados por uma matriz orgânica que lhes confere determinada estrutura arquitetônica.

Watabe (1963, 1965), estudou detalhadamente por microscopia eletrônica de transmissão, a microestrutura das carapaças de moluscos. As investigações feitas nos bivalves Pinctada martensii e Elliptio complanatus mostraram que os cristais de aragonita e calcita apresentam-se como blocos de lamelas orientadas, em conato com uma delicada matriz orgânica que circunda os cristais, e pode ser vista ainda como envelopes que se situam embaixo das organizações cristalinas; isto ocorre nas camadas nacarada e 
prismática. Saleuddin (1971), estudou por microscopia eletrônica de varredura e transmissão, a microestrutura da concha do molusco Helix e verificou que a parede da concha é composta por quatro camadas, uma nacarada, duas lamelares e uma prismática, e não por cinco, como descrito por ${ }^{4}$ Bǿggild em 1930. Saleuddin discute nesse trabalho, a íntima relação entre a matriz orgânica e os cristais de carbonato de cálcio, evidenciando sua função no processo de formação dos cristais.

Além da variedade de formas cristalinas, as carapaças de moluscos são dotadas de grande resistência mecânica. Currey (1974) investigou a resistência mecânica de 19 espécies de moluscos e constatou que as camadas nacarada e prismática são mais resistentes à fratura do que a camada lamelar. Esse resultado pode estar relacionado ao fato de essas camadas possuírem quantidade maior de material orgânico que a estrutura lamelar.

Os biominerais ocorrem nos moluscos como aragonita e/ou calcita. A vaterita é um polimorfo raro nesses organismos (HASSE et al, 2000; MELDRUM, 2003). Dauphin e Denis (2000), avaliaram qualitativamente o polimorfismo das conchas de três gastrópodes e três bivalves, e constataram somente a presença de aragonita nesses organismos. De maneira geral, as conchas dos gastrópodes são constituídas por aragonita porém, análises feitas por espectroscopia de infravermelho, indicaram a presença de aragonita e calcita na carapaça do gastrópode Concholepas concholepas (DAUPHIN et al., 2003).

Estudos recentes (WEINER; ADDADI, 1997; MELDRUM; HYDE, 2001; MANOLI et al., 2002), demonstraram a possibilidade de crescer in vitro, a partir das

\footnotetext{
${ }^{4}$ BǿGGILD, O. B. The Shell structure of the mollusks. Kgl. Danske Videnskab. Selskabs, Skrifier Naturvidenskab. Math Afdel. v.2, p.232-325, 1930.
} 
observações realizadas in vivo, cristais sintéticos, onde as faces e o polimorfismo são estabilizados pelo uso de aditivos orgânicos.

Baseados nos princípios da biomineralização, Yang et al. (2003), cristalizaram in vitro o carbonato de cálcio em presença de polissacarídeo e concluíram que existe uma interface molecular entre esses componentes que produz cristais com morfologia específica, possibilitando assim o crescimento de cristais que possam ter aplicações tecnológicas. Isso porém, somente será possível a partir da compreensão mais detalhada do processo de mineralização.

O conhecimento das leis que governam a biomineralização proporciona informações relevantes para a geração de novos materiais (CALVERT, 1994; MANN, 1988; MANN, 1993), visto que as conchas de moluscos sintetizam uma diversidade de formas cristalinas, com arquiteturas particulares, utilizando apenas o carbonato de cálcio, e tendo como substrato, a matriz orgânica.

O carbonato de cálcio é utilizado em vários setores tecnológicos, é amplamente utilizado em medicamentos, alimentos, produção de plásticos, etc. Sua aplicação é determinada pela pureza, dimensão das suas partículas, textura, estrutura e morfologia. O sucesso das aplicações depende do controle rigoroso do processo da cristalização (XIE et al., 2005). 


\section{Objetivos}

Os organismos biomineralizantes têm recebido a atenção de muitos pesquisadores, incluindo um número muito grande de espécies de moluscos. Havendo porém, várias questões em aberto, consideramos oportuno e conveniente trabalhar com o gastrópode Physa sp., pois não há na literatura investigações sobre o processo de mineralização neste organismo.

Propusemo-nos a investigar a concha desse molusco estabelecendo a correlação entre o desenvolvimento dos cristais de carbonato de cálcio, a matriz orgânica e os íons inorgânicos.

Para o melhor entendimento da biomineralização, investigamos paralelamente in vitro, a cristalização do carbonato de cálcio sob a ação de vários agentes: magnésio, serina, glicina, quitina, ácidos aspártico e glutâmico e matrizes orgânicas solúvel e insolúvel extraídas da própria concha da Physa sp.

O desenvolvimento do presente trabalho, envolveu as seguintes etapas:

- Avaliar as morfologias dos componentes inorgânicos e orgânicos por microscopia eletrônica de varredura (MEV) e microscopia eletrônica de transmissão (MET).

- Estudar qualitativamente os componentes inorgânicos e a matriz orgânica insolúvel presentes na concha do molusco, por espectroscopia de infravermelho, por análise elementar (EDS) tanto no microscópio eletrônico de varredura como no microscópio eletrônico de transmissão.

- Quantificar os elementos inorgânicos presentes na concha pela técnica da ativação de nêutrons (AAN). 
- Avaliar qualitativamente a fase mineral das conchas por difração de elétrons e quantitativamente, por difração de raios-X (DRX), com os dados ajustados pelo método de Rietveld.

- Investigar a composição orgânica da matriz insolúvel por método histoquímico.

- Crescer in vitro, cristais de carbonato de cálcio sob a ação de íons e aditivos orgânicos, caracterizando os cristais sintéticos formados por diferentes métodos disponíveis. 


\section{Materiais e Métodos}

\subsection{Parte I - Amostra - Physa sp.}

Como objeto de estudo, utilizamos a concha calcária do molusco de água doce Physa sp., espécie não identificada, pertencente ao filo Mollusca, classe Gastropoda, sub classe Pulmonata, grupo Basommatophora, família Physidae.

A concha é ovóide, espiralada em sentido anti-horário (levógira) ao redor de um eixo central denominado columela; na fase adulta, atinge cerca de $11 \mathrm{~mm}$ de altura, com diâmetro da ordem de 5mm (Figura 1). É de baixa resistência mecânica, mesmo na fase plenamente desenvolvida.

O organismo proveio da região de Ribeirão Pires (SP), sendo cultivado no laboratório em aquários de 3L contendo plantas do gênero Elodea, mantido arejado, sob iluminação natural. $\mathrm{O}$ pH do meio esteve controlado entre 7,5 e 8,5. O molusco é prolífero, os ovos são depositados dentro de pequenas bolsas gelatinosas que ficam aderidas às plantas. Após poucos dias, desenvolvem-se os caramujos medindo aproximadamente $0,5 \mathrm{~mm}$ de altura.

A alimentação consistiu de folhas de alface, flocos de alimento desidratado para peixes e algas que se desenvolvem no próprio ambiente.

A concha é essencialmente constituída por carbonato de cálcio e pequena proporção de matéria orgânica. Utilizou-se diferentes metodologias para a caracterização, descritas a seguir. 


\section{Microscopia eletrônica de varredura (MEV)}

Moluscos com carapaças medindo entre $0,5 \mathrm{~mm}$ e $10 \mathrm{~mm}$ foram anestesiados com mentol e então removidos destas com pinça. As conchas foram em seguida deixadas em $\mathrm{NaOCl} 40 \%$ (hipoclorito de sódio) por 2 horas e lavadas exaustivamente com água destilada e secas à temperatura ambiente. A morfologia foi avaliada por microscopia eletrônica de varredura.

Para acessar diferentes camadas da parede das conchas, procedeu-se a uma descalcificação parcial, usando $\mathrm{HCl}$ 0,1 mol.L $\mathrm{L}^{-1}$ (ácido clorídrico) ou EDTA 2\% (ácido etilenodiaminotetracético ) em intervalos de tempo de 1 a 5 minutos. A desproteinação foi obtida mergulhando-se as amostras em $\mathrm{NaOH}$ 1M (hidróxido de sódio ) por uma noite.

Para a observação da matriz orgânica insolúvel, fragmentos de outras amostras foram lavados com água destilada, secos à temperatura ambiente e fixados com glutaraldeído a 2,5\% em tampão cacodilato de sódio 0,05 M, pH 7,3 por 2h30min; a seguir lavou-se em solução tampão Sörensen $0,1 \mathrm{M}, \mathrm{pH} 7,3$ por uma noite, com três trocas no dia seguinte. Para a completa descalcificação mergulhou-se o material em HCl 1mol.L ${ }^{-1}$. Após várias lavagens com água destilada procedeu-se à secagem à temperatura ambiente. As amostras foram montadas nos suportes para microscopia eletrônica de varredura (MEV) usando-se cola de prata ou fita de carbono, cobertas com ouro por "sputtering" e observadas no microscópio eletrônico de varredura JEOL JSM - 840A, com tensão aceleradora de $15 \mathrm{kV}$ ou $25 \mathrm{kV}$. 


\section{Microscopia eletrônica de transmissão (MET)}

As carapaças dos moluscos foram fixadas como descrito anteriormente, mergulhadas em $\mathrm{OsO}_{4} 1 \%$ por 2 horas, lavadas em água destilada, desidratadas em concentrações crescentes de etanol $(50 \%, 70 \%, 80 \%, 95 \%$ e 100\%) e em óxido de propileno e incluídas em resina Spurr.

Pequenos fragmentos da amostra foram colocados em um recipiente contendo resina Spurr diluída em óxido de propileno puro por uma noite e submetidos a vácuo para promover a infiltração da resina. O material foi incluído na mesma resina Spurr e levado a polimerizar na estufa a $70^{\circ} \mathrm{C}$ por 4 dias. Cortes ultrafinos foram obtidos com o auxílio do ultramicrótomo Porter Blum MT-2B, usando-se uma navalha de diamante.

Cristais de carbonato de cálcio foram estudados fazendo-se réplica de $\mathrm{Pt} / \mathrm{C}$ da concha. Pequenos fragmentos da amostra foram fixados a uma lâmina de vidro com fita dupla face, posicionados no evaporador de alto vácuo modelo Kimney KSE-2 , usando ângulo de $30^{\circ}$ para a fonte de platina e $90^{\circ}$ para a fonte de carbono. A platina evaporada foi depositada e logo a seguir, depositou-se também uma camada de carbono. O material foi removido do evaporador, destacado do vidro e transferido para o $\mathrm{HCl}$ 1mol. $\mathrm{L}^{-1}$ com o auxílio de uma alça de fio de metal, para que o $\mathrm{CaCO}_{3}$ fosse dissolvido. O preparo foi finalizado após várias lavagens em água destilada e as réplicas assim obtidas, foram recolhidas sobre telas de cobre.

Para a observação da matéria orgânica, conchas de moluscos de aproximadamente 0,5mm foram fixadas com glutaraldeído a 2,5\% em tampão cacodilato de sódio $0,05 \mathrm{M}, \mathrm{pH}$ 7,3 por 2h; a seguir lavou-se em solução tampão Sörensen $0,1 \mathrm{M}, \mathrm{pH} 7,3$ por uma noite. As conchas foram completamente descalcificadas com $\mathrm{HCl}$ 0,1 mol. $\mathrm{L}^{-1}$, obtendo-se uma 
película de material orgânico; esta foi contrastada com acetato de uranila aquosa a $2 \%$ por 15 minutos, citrato de chumbo por 5 minutos e lavada com água destilada.

Todas as amostras foram coletadas em telas de cobre, secas à temperatura ambiente e observadas no microscópio eletrônico de transmissão PHILIPS CM 200, operado com tensão aceleradora de $160 \mathrm{kV}$.

\section{Microscopia de luz (ML)}

Películas da matéria orgânica obtidas como acima, foram submetidas à técnica histoquímica do PAS, para detecção de polissacarídeos, de acordo com o seguinte roteiro (SUMMER; SUMMER, 1969):

- Oxidação em ácido periódico 0,5\% (HIO) por 5 minutos.

- Lavagem com água destilada.

- Tratamento com o reativo de Schiff por 15 minutos.

- Três lavagens em banho sulfuroso recém-preparado.

- Lavagem em água destilada.

As peças foram coletadas em lamínulas, montadas em Entellan e observadas no microscópio óptico de luz modelo Axioplan 2- Zeiss (Laboratório de Microscopia Eletrônica de Varredura- Geociências - USP). O controle foi feito seguindo os passos descritos, omitindo-se a oxidação pelo ácido periódico. 


\section{Microanálise elementar - Espectroscopia de energia dispersiva (EDS) Preparo das amostras para MEV}

Fragmentos de conchas com $5 \mathrm{~mm}$ de altura e carapaças inteiras medindo $0,5 \mathrm{~mm}$ foram lavados, secos à temperatura ambiente, montados nos suportes para MEV e cobertos com carbono. A análise elementar qualitativa foi realizada a $25 \mathrm{kV}$, usando o sistema EDS, com distância de trabalho de $15 \mathrm{~mm}$.

Foram registradas imagens com elétrons secundários, das mesmas áreas analisadas por raios-X.

\section{Microanálise no MET.}

A matriz orgânica insolúvel obtida conforme já descrito, foi coletada sobre grades de cobre e submetida à análise elementar por espectroscopia de energia dispersiva (EDS) no ME Philips, operando com 160kV.

Juntamente com os espectros, foram registradas imagens das regiões analisadas.

\section{Difração de elétrons (DEAS)}

Uma pequena quantidade de conchas limpas foi triturada mecanicamente em almofariz, dispersa em água destilada e agitada manualmente até obter-se uma suspensão homogênea. Com o auxílio de uma pipeta, uma gota foi depositada sobre uma tela própria para microscopia eletrônica de transmissão, previamente recoberta com uma película de 
filme plástico recoberta com carbono. Após 5 minutos, o excesso de líquido (água) foi removido delicadamente com papel de filtro.

As telas com melhor dispersão das partículas foram previamente selecionadas sob o microscópio de luz e levadas para exame no MET usando $160 \mathrm{kV}$.

\section{Difração de raios-X (DRX)}

Para a identificação da fase mineral, conchas foram lavadas em água destilada, secas à temperatura ambiente, trituradas mecanicamente e transferidas para o portaamostras de vidro com $1 \mathrm{~cm}^{2}$ de área e analisadas por difração de raios-X. Usou-se o difratômetro Rigaku RINT 2000 de anodo rotatório com monocromador de cristal curvo de grafite. A tensão aceleradora foi de $42 \mathrm{kV}$, corrente de $120 \mathrm{~mA}$ e varredura passo a passo com incremento de $0,02^{\circ}$ (Laboratório de Química Computacional de Análises Cristalográficas e Cristalina - Instituto de Química - UNESP, Araraquara).

O refinamento da estrutura cristalina foi feito pelo método de Rietveld com o auxílio do programa GSAS (VON DREELE; LARSON, 2000; TOBY, 2001). Para a análise quantitativa de fases, foi utilizado como padrão o óxido de cério $\left(\mathrm{CeO}_{2}\right)$, preparado conforme descrito a seguir, processo desenvolvido por mim (DE PAULA; 2005).

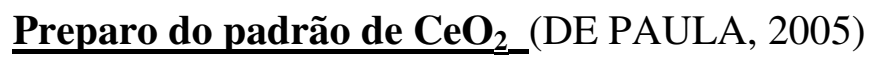

$\mathrm{O} \mathrm{CeO}_{2}$ (p.a.) foi aquecido até a temperatura de $1700^{\circ} \mathrm{C}$, em um forno e calcinado a essa temperatura durante 2 horas. Após esse período, o forno foi desligado e o resfriamento aguardado até a temperatura de aproximadamente $40^{\circ} \mathrm{C}$. Após o resfriamento, moeu-se 
mecanicamente a amostra e um novo aquecimento foi realizado, seguindo os mesmos procedimentos descritos anteriormente. Após o segundo resfriamento, o aglomerado formado pela amostra foi separado e conservado à temperatura ambiente.

O difratograma do padrão respeitou as condições de medidas descritas anteriormente.

\section{Análise por ativação de nêutrons (AAN)}

Para determinar a concentração dos elementos inorgânicos presentes na concha foi utilizada a técnica da ativação de nêutrons (SOETE; GIJBLES; HOSTE, 1972).

Cerca de 200mg de conchas foram triturados na forma de pó utilizando-se um almofariz de ágata. Alíquotas de amostras foram irradiadas de acordo com as condições indicadas na tabela que segue:

Tabela 1 - Condições de medida

\begin{tabular}{lll}
\hline Fluxo de nêutrons & Tempo de irradiação & Elementos identificados \\
\hline $5 \times 10^{11} \mathrm{n} \cdot \mathrm{cm}^{-2} \cdot \mathrm{s}^{-1}$ & $4 \mathrm{~min}$ & $\mathrm{Mn}, \mathrm{Na}$ \\
$5 \times 10^{12} \mathrm{n} \cdot \mathrm{cm}^{-2} \cdot \mathrm{s}^{-1}$ & $16 \mathrm{~h}$ & $\mathrm{Ba}, \mathrm{Br}, \mathrm{Ca}, \mathrm{Sr}$ e $\mathrm{Zn}$ \\
\hline
\end{tabular}

A aquisição dos dados foi realizada com o Sistema Canberra com detector GX2020 (Laboratório de Análise por Ativação Neutrônica - IPEN). 


\section{Cromatografia (CLAE)}

\section{Separação das matrizes orgânicas solúvel e insolúvel}

Cerca de $8 \mathrm{mg}$ de conchas (5mm a $10 \mathrm{~mm}$ de altura) foram imersas em $\mathrm{NaOCl} 20 \%$ para a remoção de detritos orgânicos; foram então extensivamente lavadas com água destilada, secas à temperatura ambiente e trituradas mecanicamente. A descalcificação foi iniciada pela adição de $30 \mathrm{~mL}$ de $\mathrm{HCl} 1 \mathrm{~mol}^{-1}$ ao pó obtido. Durante os 3 dias subseqüentes, o mesmo ácido foi adicionado em pequenas doses, até completar o volume final de $60 \mathrm{~mL}$ (amostra $+\mathrm{HCl}$ ). Após esse período, a amostra descalcificada foi submetida à diálise durante 7 dias e centrifugada para sedimentar a fração insolúvel.

A matriz solúvel foi submetida à análise de aminoácidos, enquanto que a matriz insolúvel foi avaliada no espectrofotômetro de infravermelho Shimadzu FTIR-8300 acoplado ao microscópio AIM-8800 (Laboratório de Química Supramolecular e Nanotecnologia, Instituto de Química - USP).

\section{Análise de aminoácidos da matriz solúvel (ARRIZON-LOPEZ et al., 1991)}

Esta análise foi realizada no Laboratório de Química de Peptídeos do IQ-USP. Resumidamente, a fração solúvel $(\sim 5 \mathrm{ml})$ foi seca a vácuo em uma estação de trabalho "Pico Tag” da Waters (Millipore, EUA). O resíduo sólido resultante foi submetido à hidrólise ácida gasosa - em presença de $\mathrm{HCl} 6 \mathrm{M}$ e de cristais de fenol - a $110^{\circ} \mathrm{C}$ por 24 horas. $\mathrm{O}$ hidrolisado total foi seco a vácuo na mesma estação de trabalho e posteriormente diluído para a determinação da composição de aminoácidos em um analisador automático modelo 7300 da Beckman Instruments, Inc. (EUA). 
Este sistema emprega o método de derivatização pós-coluna, no qual os aminoácidos provenientes de hidrólise ácida são separados por cromatografia líquida de alta eficiência em uma coluna de troca iônica sulfonada de poliestireno da Beckman Instruments, Inc. $(0,40 \mathrm{~cm}$ x $12,00 \mathrm{~cm})$. Os aminoácidos são detectados como produtos de reação com ninidrina a 440 ou 570nm. A quantidade de cada aminoácido pode ser calculada por comparação a uma mistura padrão contendo 19 aminoácidos usuais de concentração conhecida.

\section{Espectroscopia de infravermelho (IV)}

Aproximadamente $2 \mathrm{mg}$ de conchas foram triturados para a análise da composição carbonácea. O material orgânico insolúvel foi separado, conforme descrito anteriormente (protocolo para a separação das matrizes orgânicas solúvel e insolúvel) e preparado para análise.

Foram preparadas pastilhas de $\mathrm{KBr}$ (brometo de potássio) das amostras inorgânica e orgânica, e os espectros foram coletados de 4000 a $650 \mathrm{~cm}^{-1}$, com resolução de $4 \mathrm{~cm}^{-1} \mathrm{em}$ 64 varreduras. Usou-se um espectrofotômetro de infravermelho Shimadzu FTIR-8300 acoplado ao microscópio AIM-8800 (Laboratório de Química Supramolecular e Nanotecnologia, Instituto de Química - USP). 


\subsection{Parte II - Crescimento de cristais de $\mathrm{CaCO}_{3}$.}

\section{Soluções de $\mathrm{CaCO}_{3}$.}

\section{Solução A}

Misturou-se volumes iguais de $\mathrm{CaCl}_{2}(20 \mathrm{mM}) \mathrm{pH} 6,0, \mathrm{NaHCO}_{3}(20 \mathrm{mM}) \mathrm{pH} 9,5 \mathrm{e}$ $\mathrm{MgCl}_{2} \cdot \mathrm{H}_{2} \mathrm{O}(40 \mathrm{mM}) \mathrm{pH}$ 6,0 visando a cristalização da aragonita.

\section{Solução B}

Para a indução do crescimento de cristais de calcita, esta solução foi idêntica à solução A, porém omitindo-se o cloreto de magnésio.

Volumes iguais $(200 \mathrm{~mL}$ ) de cada solução (A e B) foram colocados em béqueres individuais, mantidos em banho-maria à temperatura de $27 \pm 0,5^{\circ} \mathrm{C}$ por 7 dias. Lamínulas depositadas na superfície de cada solução serviram como substrato para o crescimento de cristais.

Após o período de 7 dias, formaram-se cristais nas paredes dos béqueres, na superfície da solução e nas lamínulas flutuantes.

Ao fim de 7 dias, as lamínulas foram cuidadosamente recolhidas com o auxílio de uma pinça, lavadas com água destilada, depositadas sobre papel de filtro e secas à temperatura ambiente .

O excesso de solução foi removido dos béqueres; os cristais crescidos nas paredes foram lavados com água destilada, secos à temperatura ambiente, raspados e recolhidos. 


\section{Aditivos}

$\mathrm{Na}$ análise de aminoácidos da concha feita através de cromatografia líquida de alta eficiência (CLAE), constatou-se que o ácido aspártico, o ácido glutâmico, a glicina e serina são os componentes orgânicos encontrados em maior proporção na matriz orgânica solúvel da concha de Physa. Baseando-se nesse resultado, os quatro aminoácidos foram selecionados e adicionados às soluções A e B, nas concentrações de $0,1 \mathrm{mg}^{\mathrm{m}} \mathrm{mL}^{-1} \mathrm{e}$ 1mg.mL $L^{-1}$. A tabela 2 traz as especificações desses aminoácidos:

Tabela 2- Aditivos orgânicos

\begin{tabular}{llll}
\hline Aditivo & Fórmula & Pureza & Procedência \\
\hline L-aspártico & $\mathrm{C}_{4} \mathrm{H}_{7} \mathrm{NO}_{4}$ & $98 \%$ & Aldrich \\
L-glutâmico & $\mathrm{C}_{5} \mathrm{H}_{9} \mathrm{NO}_{4}$ & $99 \%$ & Aldrich \\
L- serina & $\mathrm{C}_{3} \mathrm{H}_{7} \mathrm{NO}_{3}$ & $99 \%$ & Aldrich \\
Glicina & $\mathrm{H}_{2} \mathrm{NCH}_{2} \mathrm{CO}_{2} \mathrm{H}$ & $99 \%$ & Aldrich \\
\hline
\end{tabular}

A fração orgânica insolúvel da concha, foi depositada em uma cubeta de aproximadamente $1,5 \mathrm{~cm}$ de diâmetro e seca à temperatura ambiente por evaporação. Obteve-se um aglomerado de matéria orgânica que foi cuidadosamente colocado na superfície das soluções A e B.

A fração orgânica solúvel extraída da concha foi adicionada às soluções A e B à razão de $15 \mathrm{~mL}$ de substância contendo matriz orgânica solúvel por litro.

A quitina utilizada como aditivo foi extraída do exoesqueleto de camarões que foram intensamente lavados com água corrente, enxaguados inúmeras vezes com água destilada e secos à temperatura ambiente; foram então moídos mecanicamente e 
desmineralizados com $\mathrm{HCl} 1$ mol. $\mathrm{L}^{-1}$ durante 5h; o material obtido foi lavado com água destilada e tratado com $\mathrm{NaOH} 1 \mathrm{~mol} . \mathrm{L}^{-1}$ durante $3 \mathrm{~h}$ para desproteinação. A quitina extraída foi lavada com água destilada, seca à temperatura ambiente, moída novamente e passada em uma peneira com 200 mesh de granulometria (adaptação do método descrito por PERCOT; VITON; DOMARD, 2003).

A pureza da quitina foi determinada por espectroscopia de infravermelho com os dados coletados de 4000 a $650 \mathrm{~cm}^{-1}$. A cristalinidade deste material foi avaliada por difração de raios-X empregando o difratômetro Rigaku RINT 2100 Ultima, com monocromador de cristal de grafite; usou-se tensão aceleradora de $40 \mathrm{kV}$, corrente de $30 \mathrm{~mA}$ e passo de $0.02^{\circ}$. A medida foi realizada no intervalo de $5^{\circ}-50^{\circ}$ (Laboratório de Cristalografia - Instituto de Física, USP).

A quitina foi adicionada às soluções $\mathrm{A}$ e $\mathrm{B}$ nas concentrações de $0,1 \mathrm{mg} \cdot \mathrm{mL}^{-1} \mathrm{e}$ $1 \mathrm{mg} \cdot \mathrm{mL}^{-1}$.

\section{Estudo da morfologia dos cristais.}

A morfologia e a distribuição dos cristais foi avaliada por MEV e por MO, respectivamente, nos microscópio JEOL JSM - 840A, com tensão aceleradora de 25kV e no microscópio óptico modelo Axioplan 2-Zeiss (Laboratório de Microscopia Eletrônica de Varredura- Geociências - USP).

A partir das imagens obtidas por MEV e MO, os cristais crescidos sob a ação dos diferentes aditivos, foram medidos (diâmetro ou comprimento) com o auxílio do programa de imagens Image $J$. 


\section{Estudo do polimorfismo dos cristais.}

O estudo do polimorfismo dos cristais por difração de elétrons e espectroscopia de infravermelho seguiu os procedimentos descritos anteriormente.

Para a análise por difração de raios-X, os cristais sintetizados de $\mathrm{CaCO}_{3}$ foram secos à temperatura ambiente e depositados sobre uma lamínula de vidro de aproximadamente $1 \mathrm{~cm}^{2}$ de área. As análises foram feitas utilizando-se os seguintes equipamentos e condições de medidas:

- Difratômetro Rigaku RINT 2000 de anodo rotatório com monocromador de cristal curvo de grafite. Tensão aceleradora de $42 \mathrm{kV}$, corrente de $120 \mathrm{~mA}$ e varredura passo a passo com incremento de $0,02^{\circ}$ (Laboratório de Química Computacional de Análises Cristalográficas e Cristalinas, Instituto de Química - UNESP, Araraquara).

- Difratômetro Rigaku com monocromador de grafite. Tensão aceleradora 40kV, corrente de $20 \mathrm{~mA}$ e passo de $0,05^{\circ}$ (Laboratório de Cristalografia, Instituto de Física - USP).

- Difratômetro Rigaku RINT 2100 Ultima com monocromador de cristal de grafite. Tensão aceleradora de $40 \mathrm{kV}$, corrente de $30 \mathrm{~mA}$ e passo de $0.02^{\circ}$ (Laboratório de Cristalografia , Instituto de Física - USP).

As fases foram quantificadas com o uso do programa GSAS. 


\section{Resultados}

\subsection{Parte I - Physa sp.}

\section{Morfologia dos componentes orgânicos e inorgânicos.}

A concha estudada é espiralada no sentido anti-horário, isto é, levógira. No estágio inicial do desenvolvimento da concha, com altura de aproximadamente $0,5 \mathrm{~mm}$, existe apenas a primeira protoconcha (Figura 2). A partir de $1 \mathrm{~mm}$ de altura apresenta uma segunda protoconcha e bandas de crescimento meridionais em toda sua superfície externa (Figura 3). A figura 4 é uma vista topográfica do ápice em detalhe correspondendo às regiões mais antigas da carapaça. A seta define o sentido da espiral, em torno do eixo vertical. A Figura 5 é uma imagem correspondente, da face interna, neste estágio.

Imagens ampliadas da superfície externa de conchas com altura de 0,5-2mm, mostram uma cobertura de placas circulares com diâmetro aproximado de 1,6 $\mu \mathrm{m}$ em toda sua extensão, e áreas, com aparência porosa (*), que podem ser de material orgânico (Figura 6). A Figura 7 é uma ampliação da Figura 6. Esse tipo de estrutura não foi encontrada em conchas maiores que $2 \mathrm{~mm}$.

Fraturas perpendiculares à parede de uma concha adulta (Figura 8) revelaram a presença de 5 camadas, a partir da superfície externa para interna. A superfície externa corresponde a uma delicada película orgânica, o perióstraco, que serve como matriz para a deposição de $\mathrm{CaCO}_{3}$. As demais camadas cristalinas estão organizadas como segue: 1) logo abaixo do perióstraco, observa-se a camada prismática, com prismas verticais de aproximadamente $1,5 \mu \mathrm{m}$ de altura; 2) camada lamelar formada por ripas arranjadas em dois eixos longitudinais a aproximadamente $120^{\circ}$; 3) camada com espessura entre $25-30 \mu \mathrm{m}$ 
formada por placas organizadas em colunas; 4) lamelas estreitas, com disposição dos cristais simétrica àquela da camada 2 ; e 5) camada nacarada, caracterizada por ter a superfície brilhante, com boa refletividade à luz; ela possui ondulações irregulares em conchas jovens de 0,5-2mm (Figura 10) e placas poligonais empilhadas, em conchas maiores (Figura 11). Tabletes isolados são apresentados em detalhes nas figuras 12 e 13 . Erodindo-se a camada nacarada com $\mathrm{HCl} 0,1 \mathrm{~mol} . \mathrm{L}^{-1}$ durante $5 \mathrm{~min}$, observam-se feixes de cristais superpostos, orientados em sentidos opostos (Figura 14).

A partir das observações morfológicas das camadas da concha, propomos para a carapaça de conchas adultas, o modelo representado na Figura 9.

Cristais de aragonita organizados em degraus de aproximadamente $0,8 \mu \mathrm{m}$ de altura recobrem externamente a abertura das conchas jovens (Figura 15), sendo menos evidentes em conchas adultas de $7-10 \mathrm{~mm}$ de altura.

Para acessar as regiões cristalinas internas, que recobrem a parede da concha, estas foram erodidas quimicamente com EDTA ou $\mathrm{HCl} 1$ mol.L $\mathrm{L}^{-1}$ durante 5 minutos. Tal procedimento revelou abaixo do perióstraco, cristais de aragonita em forma de agulhas, distribuídos randomicamente (Figura 16).

Na região do ápice, existe uma camada de aragonita lamelar (Figura 17) e ripas formando entre si, ângulo de aproximadamente $90^{\circ}$ (Figura 18). Nessa região, foram encontrados ainda, cristais poliédricos e romboédricos em contato com a matriz orgânica (Figuras 19 e 20). Romboedros foram localizados também, nas proximidades da abertura da concha. Ao longo da columela ocorrem cristais lamelares e romboédricos de calcita (Figuras 21, 22 e 23).

Esferas com diâmetro entre $0,5 \mu \mathrm{m}$ e $1 \mu \mathrm{m}$ são encontradas em toda a extensão da concha. Erodindo-se a camada nacarada observou-se a presença de esferas com diâmetro de 
aproximadamente $0,5 \mu \mathrm{m}$, depositadas entre as camadas nacarada e lamelar (Figura 24). Nota-se nessa região a presença de matéria orgânica (Figura 25); na região do ápice foram encontrados em grande quantidade, aglomerados de esferas (Figura 26).

Amostras desproteinadas com $\mathrm{NaOH}$ durante uma noite apresentaram lamelas organizadas em agregados esféricos (Figura 27 e 28) e depositadas sobre feixes prismáticos (Figura 29), por toda a extensão da concha.

Após fixação com glutaraldeído e descalcificação com $\mathrm{HCl}$ 0,1mol.L $\mathrm{L}^{-1}$ durante 1min, notou-se cristais recobertos por uma membrana orgânica (Figuras 30 e 31). Com a completa descalcificação, restaram apenas fibras em várias regiões da amostra (Figura 32). 

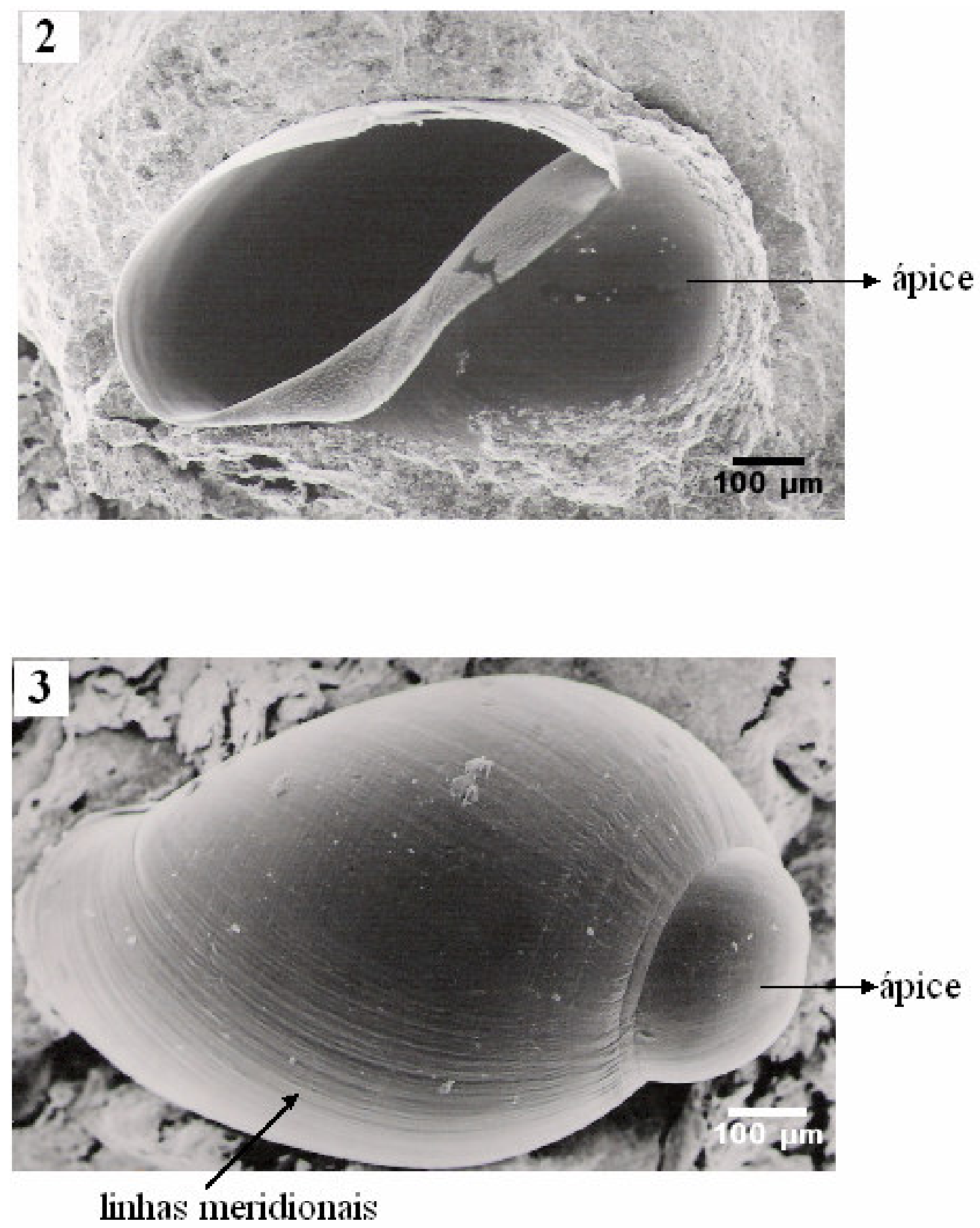

Figura 2 - Concha jovem com aproximadamente $0,8 \mathrm{~mm}$ de altura. Figura 3 - Concha com $1 \mathrm{~mm}$ de altura, com linhas de crescimento. 

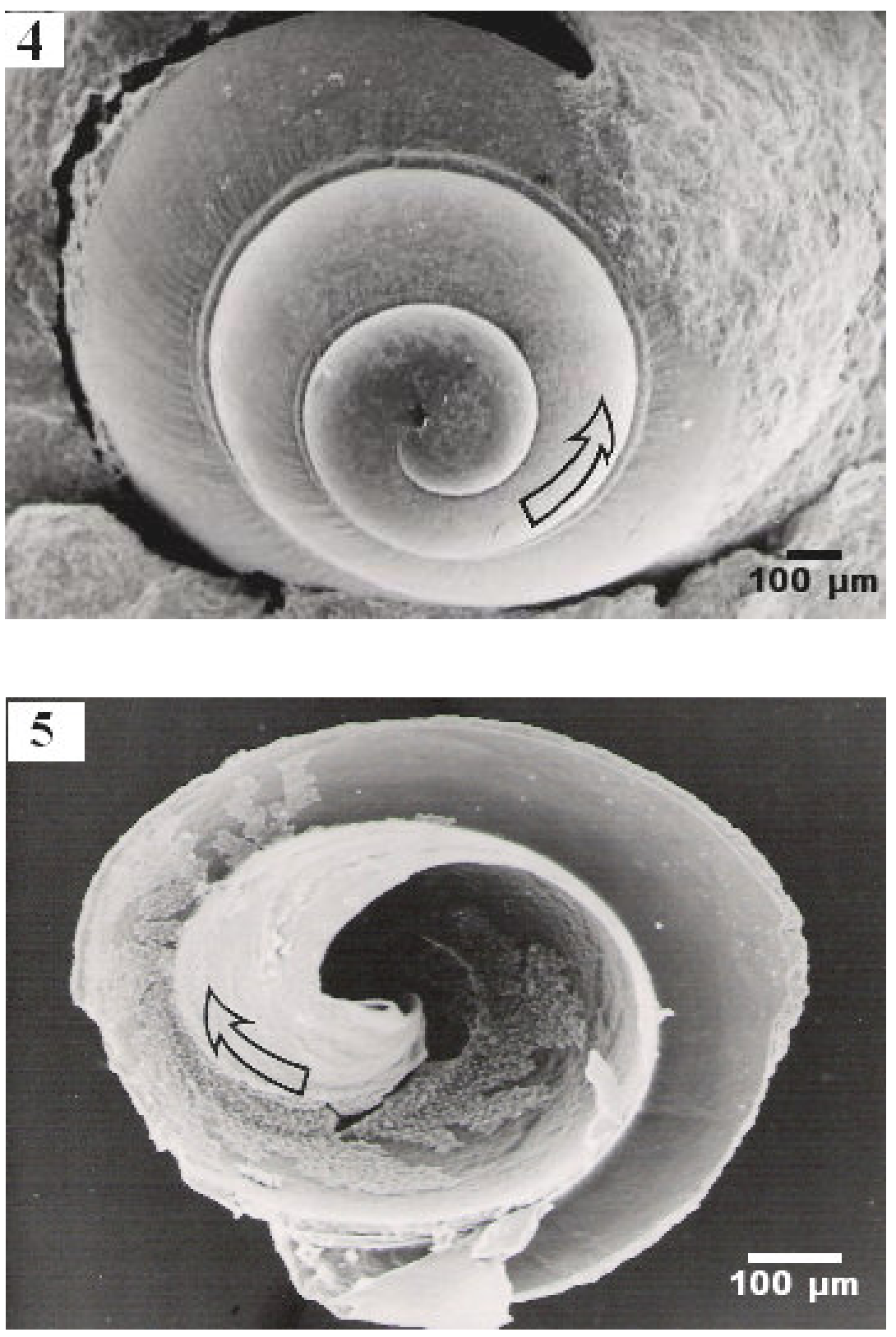

Figura 4 - Vista topográfica do ápice, espiralado no sentido anti-horário. Figura 5 - Face interna do ápice parcialmente descalcificado. 

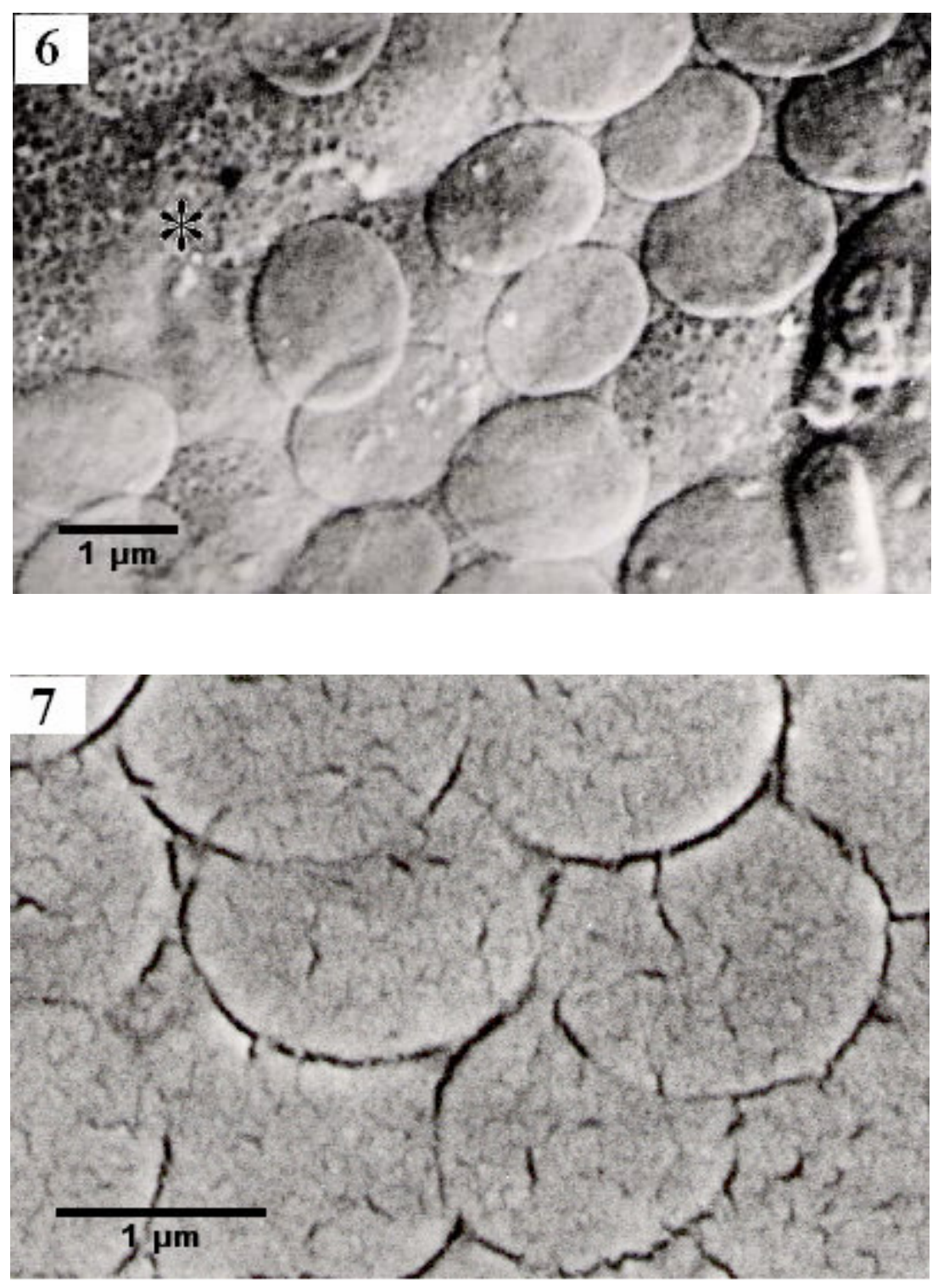

Figura 6 - Unidades circulares presentes na superfície externa de conchas com altura de 0,5-2mm. Figura 7 - Detalhes das unidades circulares vistas na Figura 6. 


\section{8}
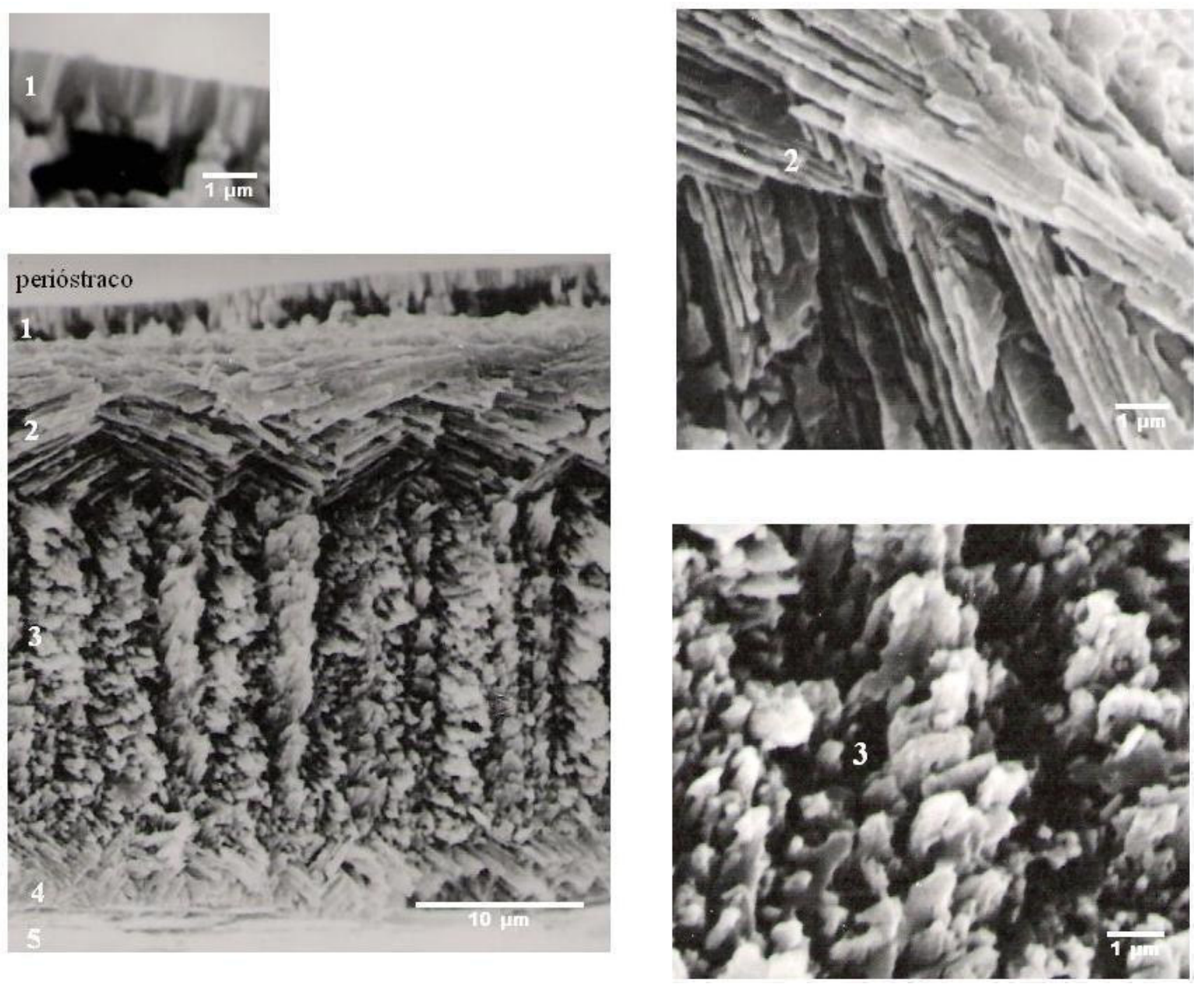

Figura 8 - Fratura perpendicular da concha com cerca de $4 \mathrm{~mm}$ de altura, ilustrando 5 camadas. O perióstraco representa a superfície externa e a camada nacarada, a mais interna da concha. 


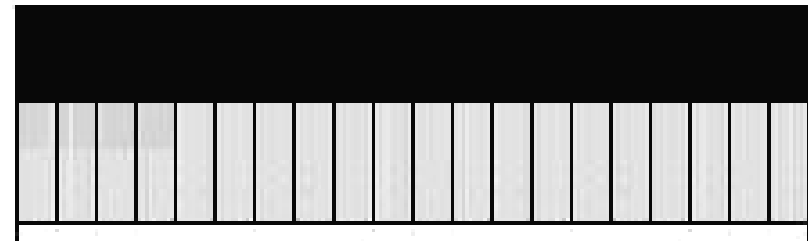

perióstraco

1- camada prismática

2- camada lamelar

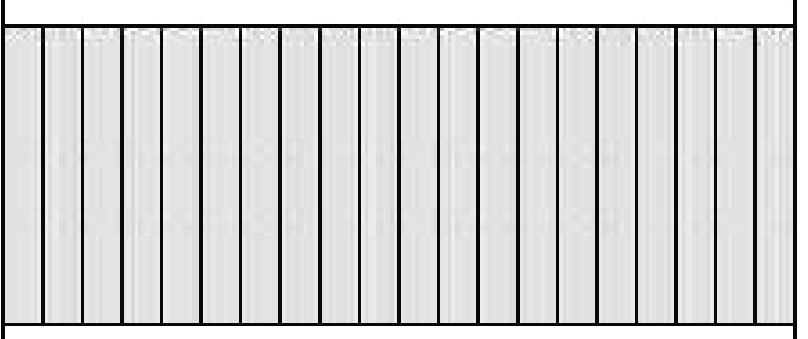

3- camada prismática

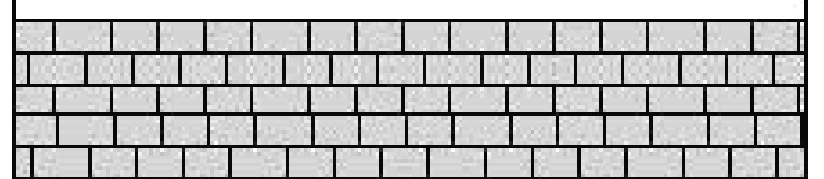

4- camada lamelar

5-camada nacarada

Figura 9 - Diagrama das camadas da concha. 

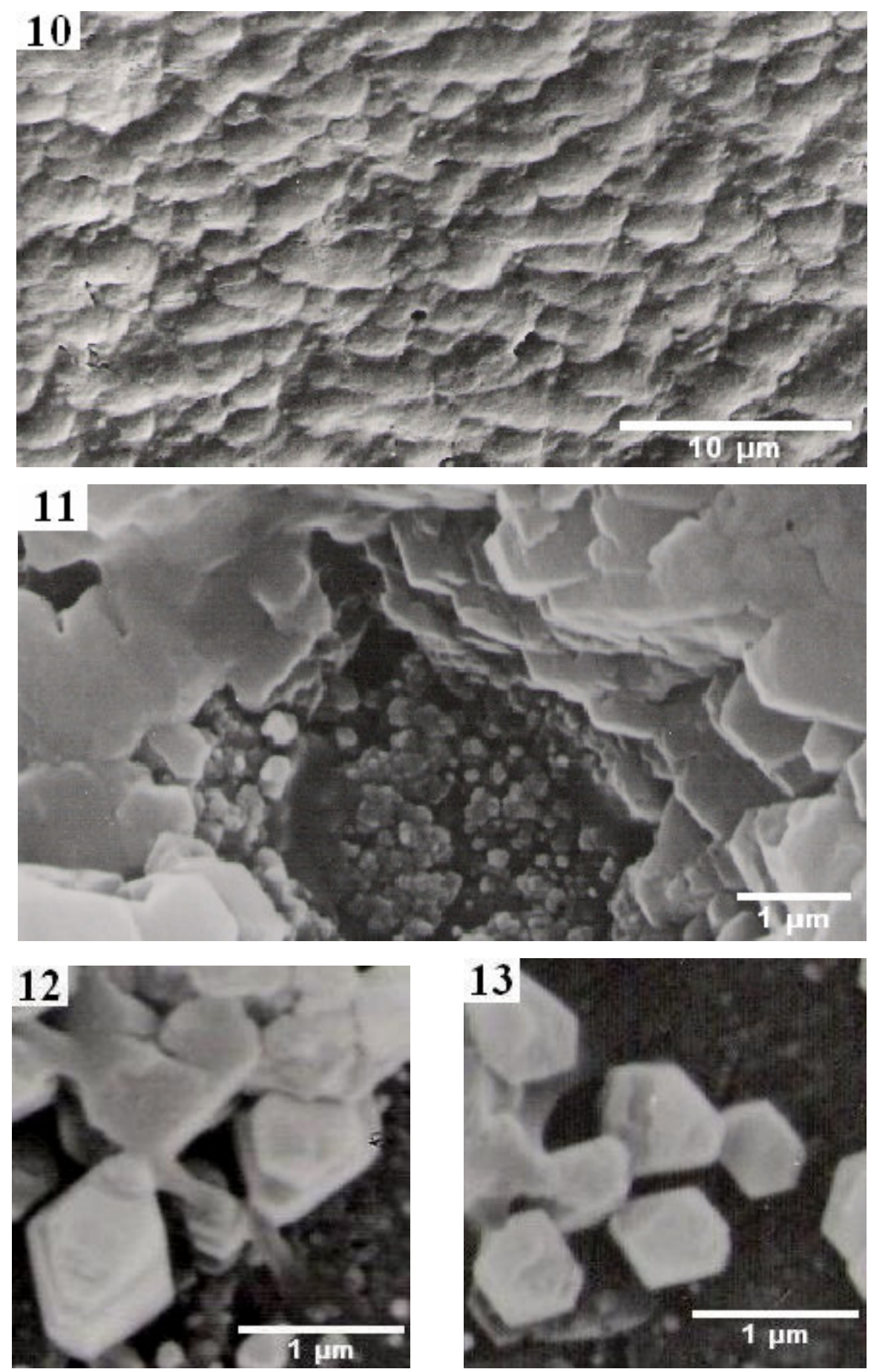

Figura 10 - Camada nacarada exibindo ondulações.

Figura 11- Camada nacarada exibindo tabletes poligonais empilhados. Figuras 12 e 13 - Tabletes poligonais em detalhe. 

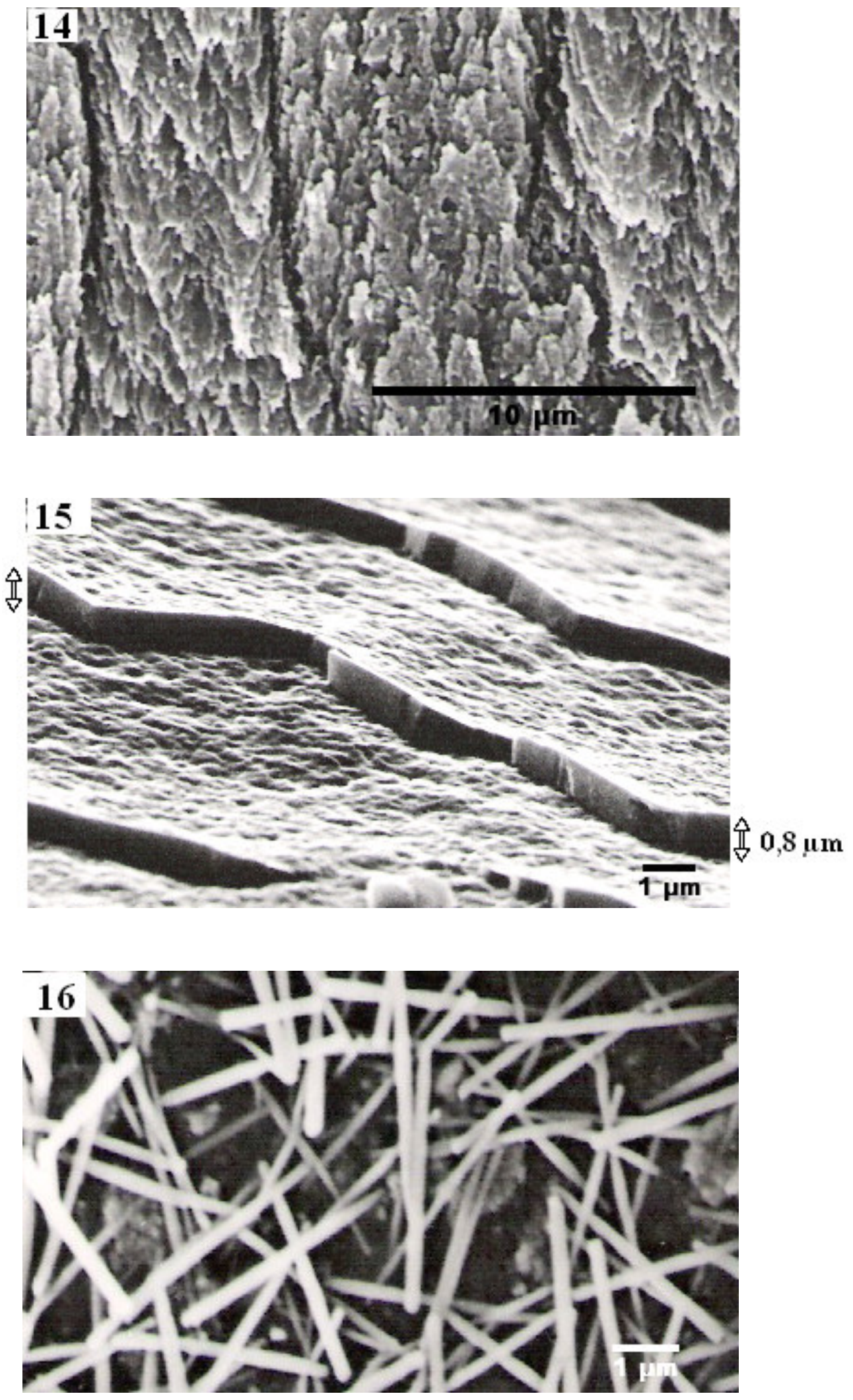

Figura 14 - Prismas orientados em dois sentidos na superfície interna da concha.

Figura 15 - Aragonita orientada em degraus ao longo da abertura.

Figura 16 - Agregados de prismas encontrados entre o perióstraco e a camada prismática. 

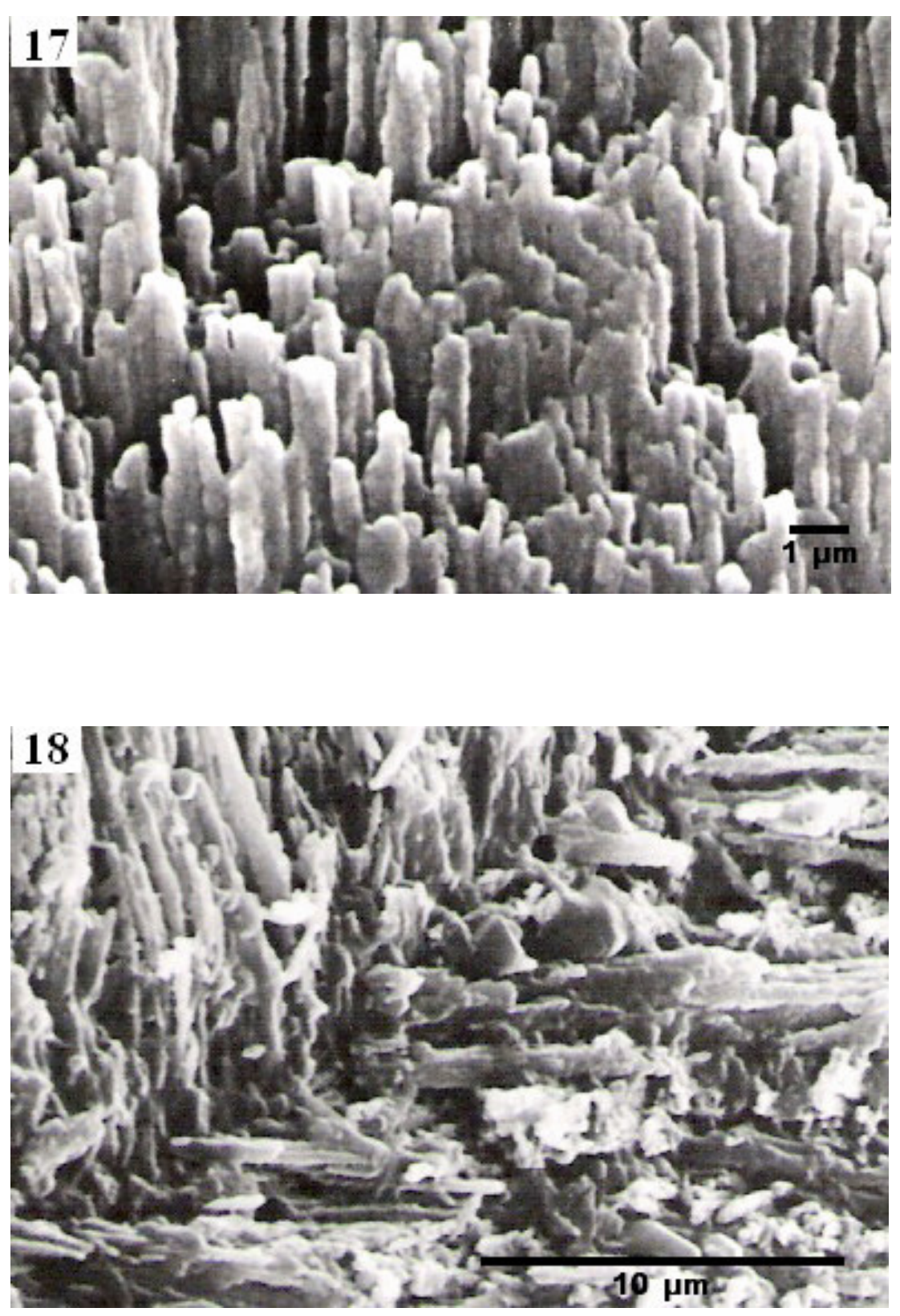

Figura 17 - Lamelas encontradas na região interna do ápice.

Figura 18 - Ripas de aragonita encontradas na região interna do ápice. 

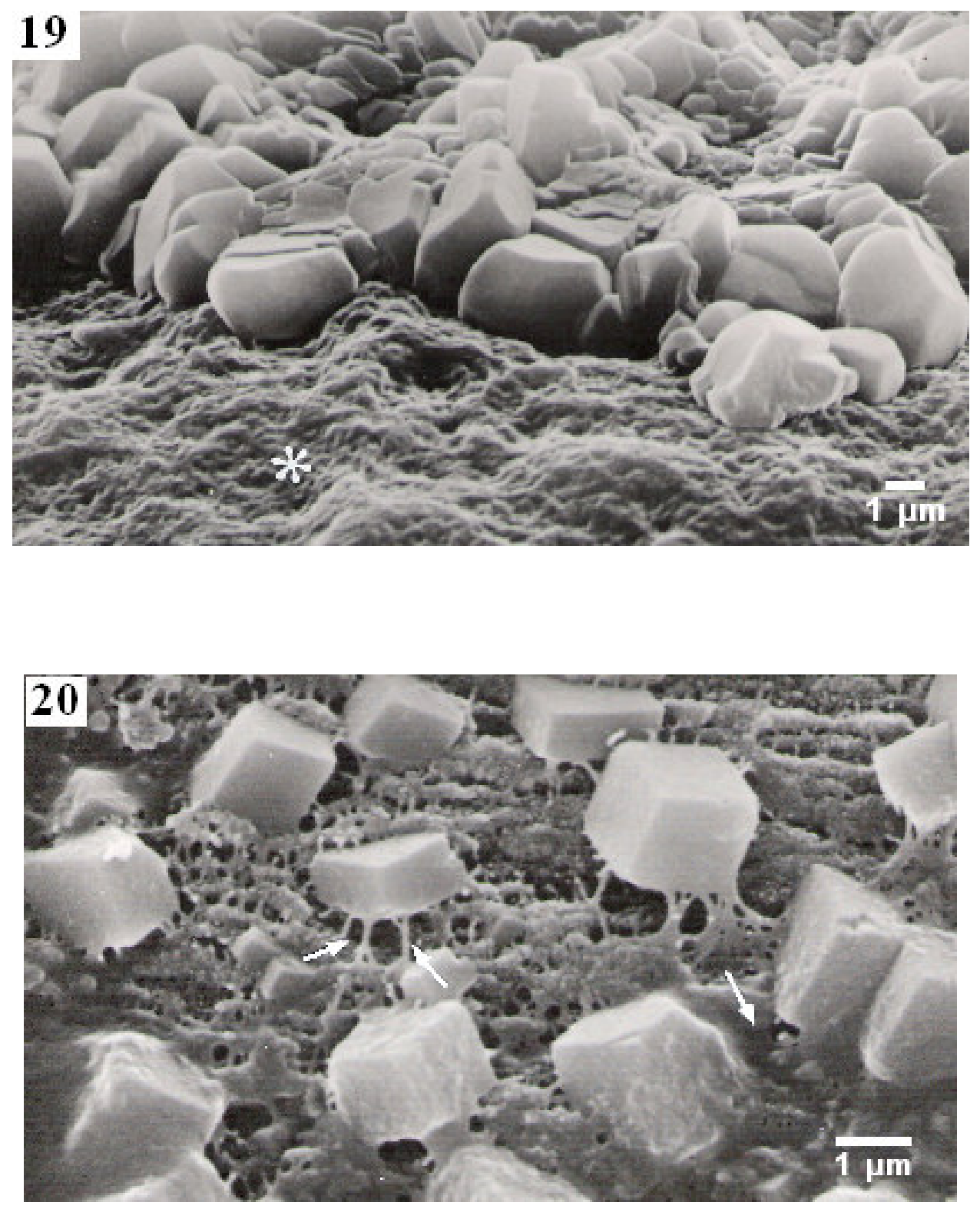

Figura 19 - Cristais poliédricos de aragonita sobre matriz orgânica $(*)$. Figura 20 - Romboedros de calcita em contato com a matriz orgânica $(\uparrow)$. 

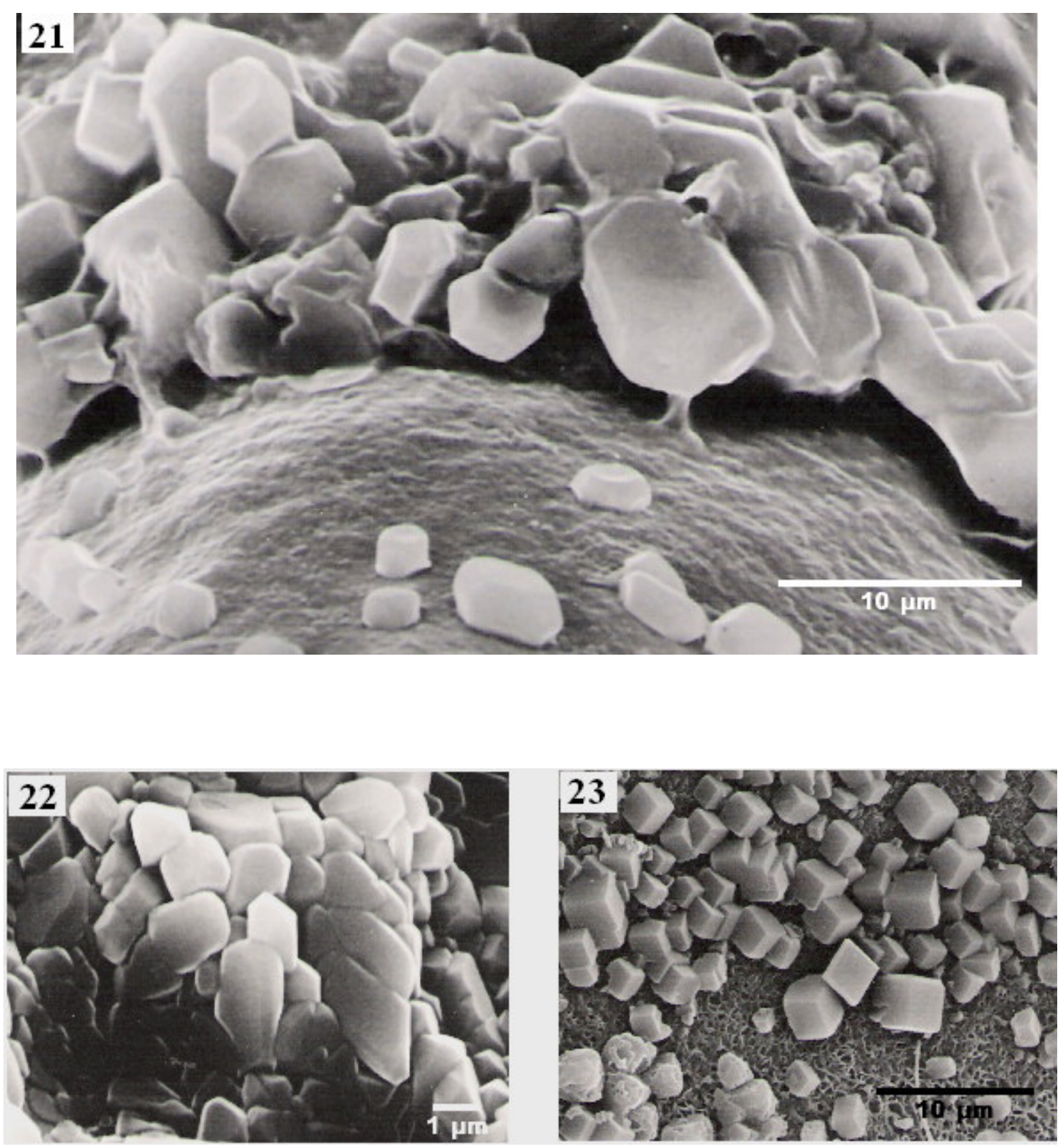

Figura 21 - Cristais de aragonita encontrados na columela.

Figura 22 - Cristais observados na columela e nas proximidades do ápice.

Figura 23 - Romboedros localizados sobre a columela. 

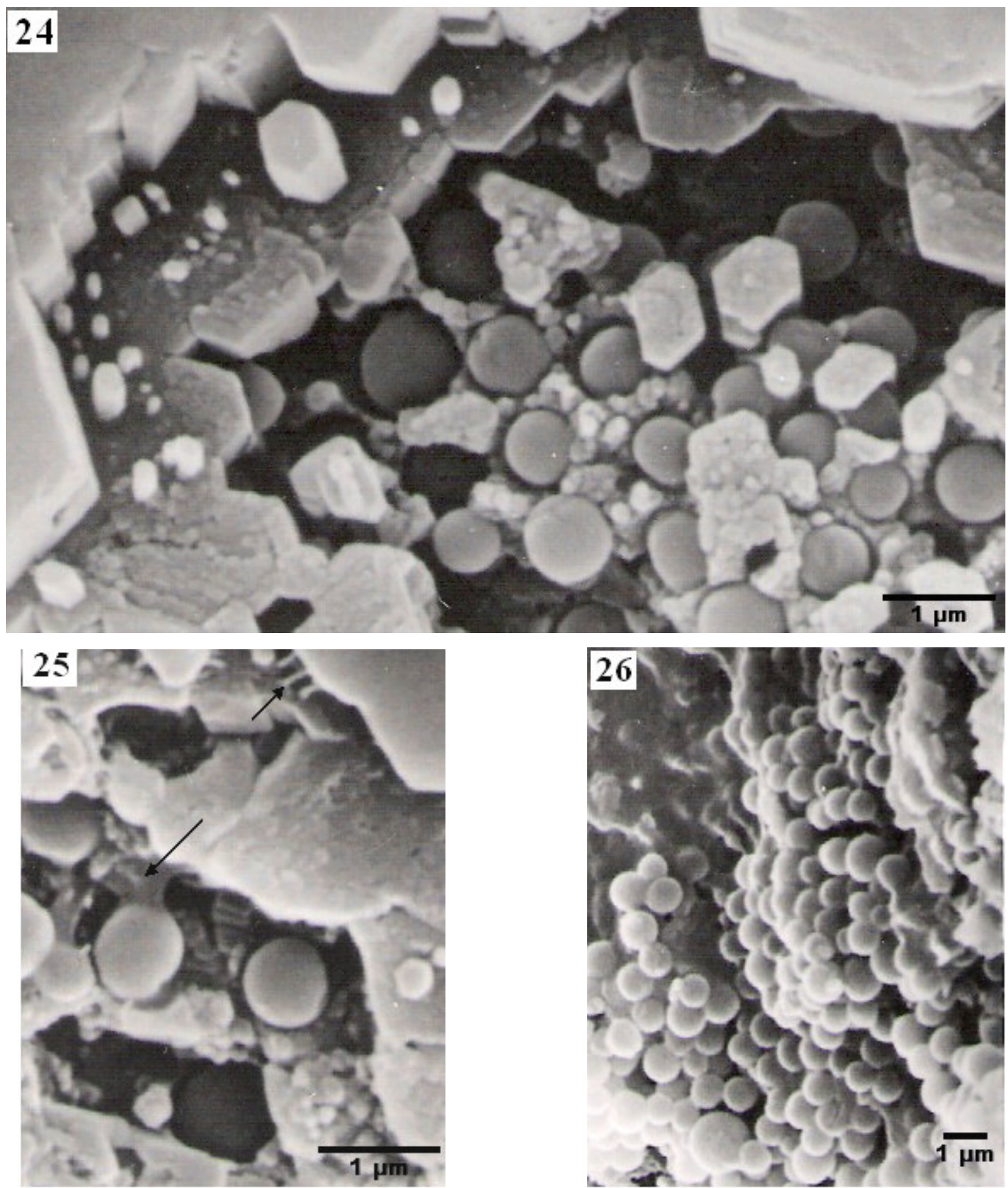

Figura 24 - Esferas localizadas entre as camadas lamelar e nacarada.

Figuras 25 - Esferas em contato com material orgânico.

Figura 26 - Esferas localizadas na região interna do ápice. 

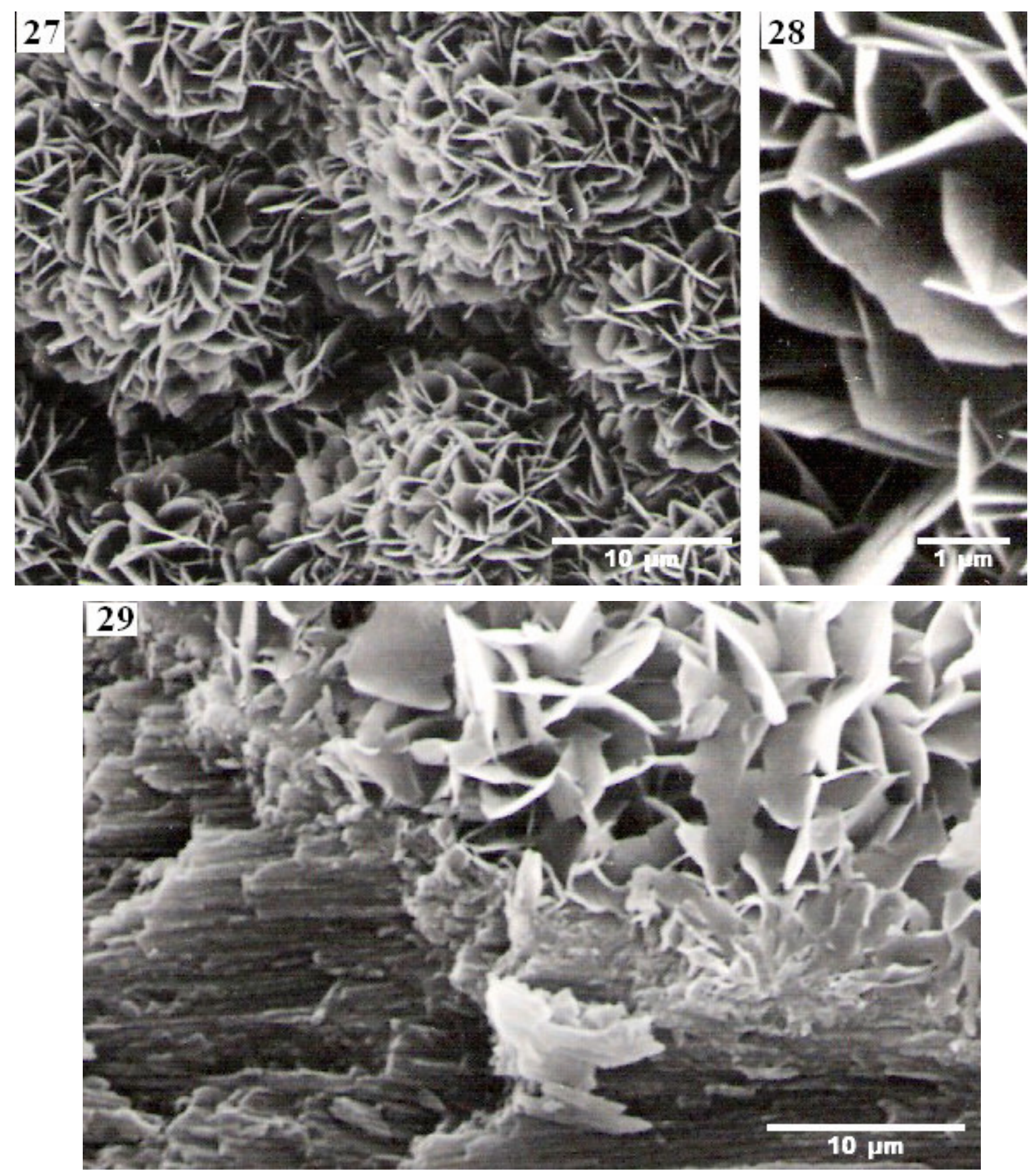

Figura 27 - Lamelas de aragonita localizadas por toda a extensão da amostra.

Figura 28 - Detalhe da Figura 27.

Figura 29 - Lamelas depositadas sobre feixes prismáticos por toda a parede interna da concha. 

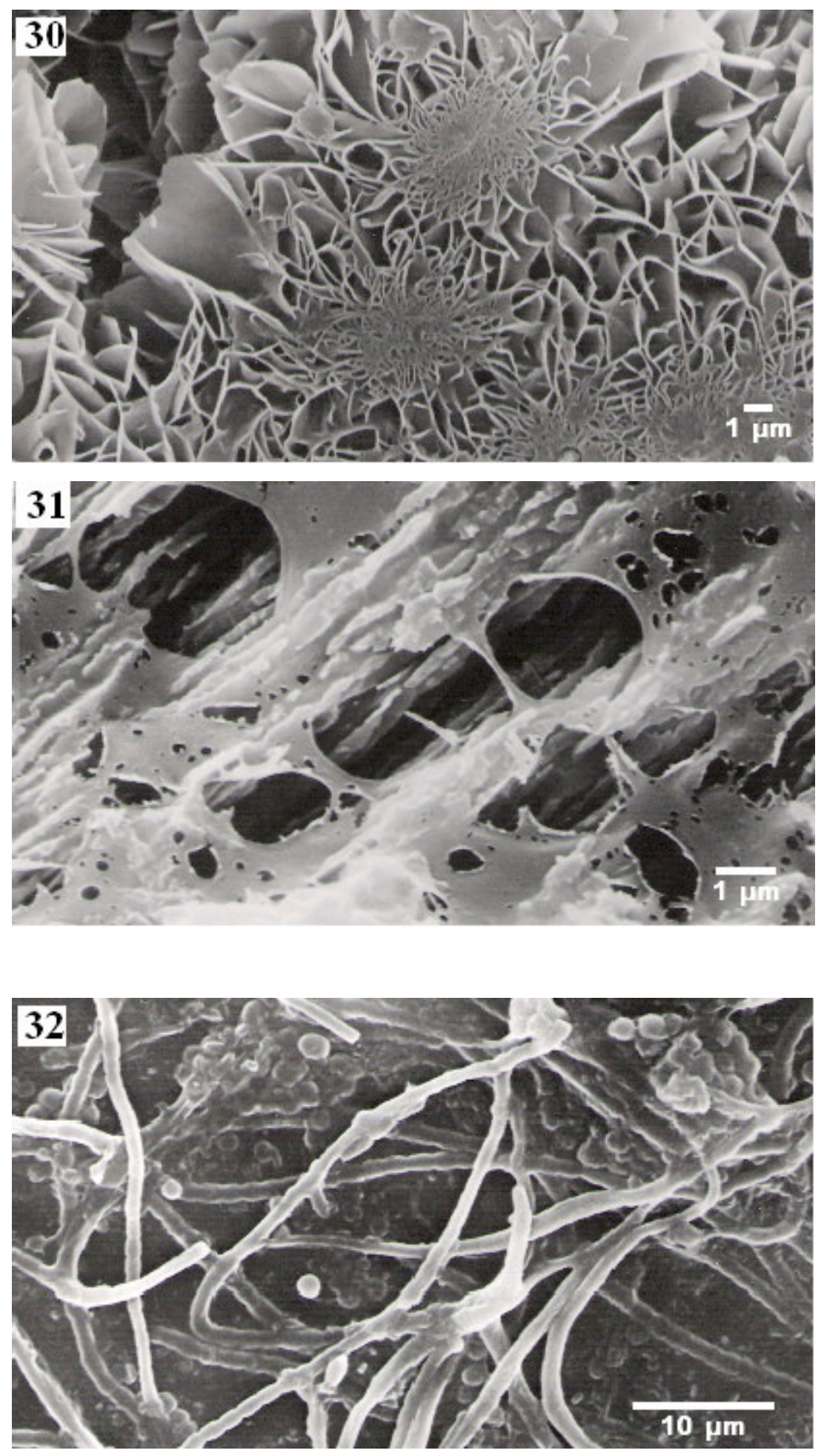

Figuras 30 - Matriz orgânica depositada sobre lamelas

Figura 31- Matéria orgânica depositada sobre feixe de prismas.

Figura 32 - Material fibroso distribuído por toda a amostra após completa descalcificação 
Em cortes ultrafinos, o perióstraco da Physa, que possui aproximadamente $1 \mu \mathrm{m}$ espessura (Figura 33), revelou nanoestruturas. Externamente, existe uma camada homogênea $(\mathrm{H})$ de aproximadamente $30 \mathrm{~nm}$ de espessura que é seguida por três lamelas densas(L), com cerca de $19 \mathrm{~nm}$ de espessura e comprimento máximo de $1 \mu \mathrm{m}$; estas apresentam certa periodicidade, surgindo em grupos de três e duas lamelas; logo abaixo, situa-se a camada sublamelar (SL), com aproximadamente $800 \mathrm{~nm}$ de espessura e estrutura granular. Na superfície externa do perióstraco foram encontrados depósitos localizados de material fibroso (Figura 34).

Após completa descalcificação observou-se que a matriz orgânica de conchas jovens, de $0,5 \mathrm{~mm}$ de altura, é constituída por discos com diâmetro de aproximadamente 1,6um de diâmetro (Figura 35). Conchas com altura superior a $2 \mathrm{~mm}$ apresentaram apenas uma fina película (Figura 36).

Réplicas de fragmentos da concha parcialmente descalcificados, revelaram cristais (Figura 37 ) distribuídos randomicamente; empilhamento de placas com cerca de 170nm de largura (Figura 38) e lamelas orientadas a cerca de $120^{\circ}$ em um mesmo plano (Figura 39). 


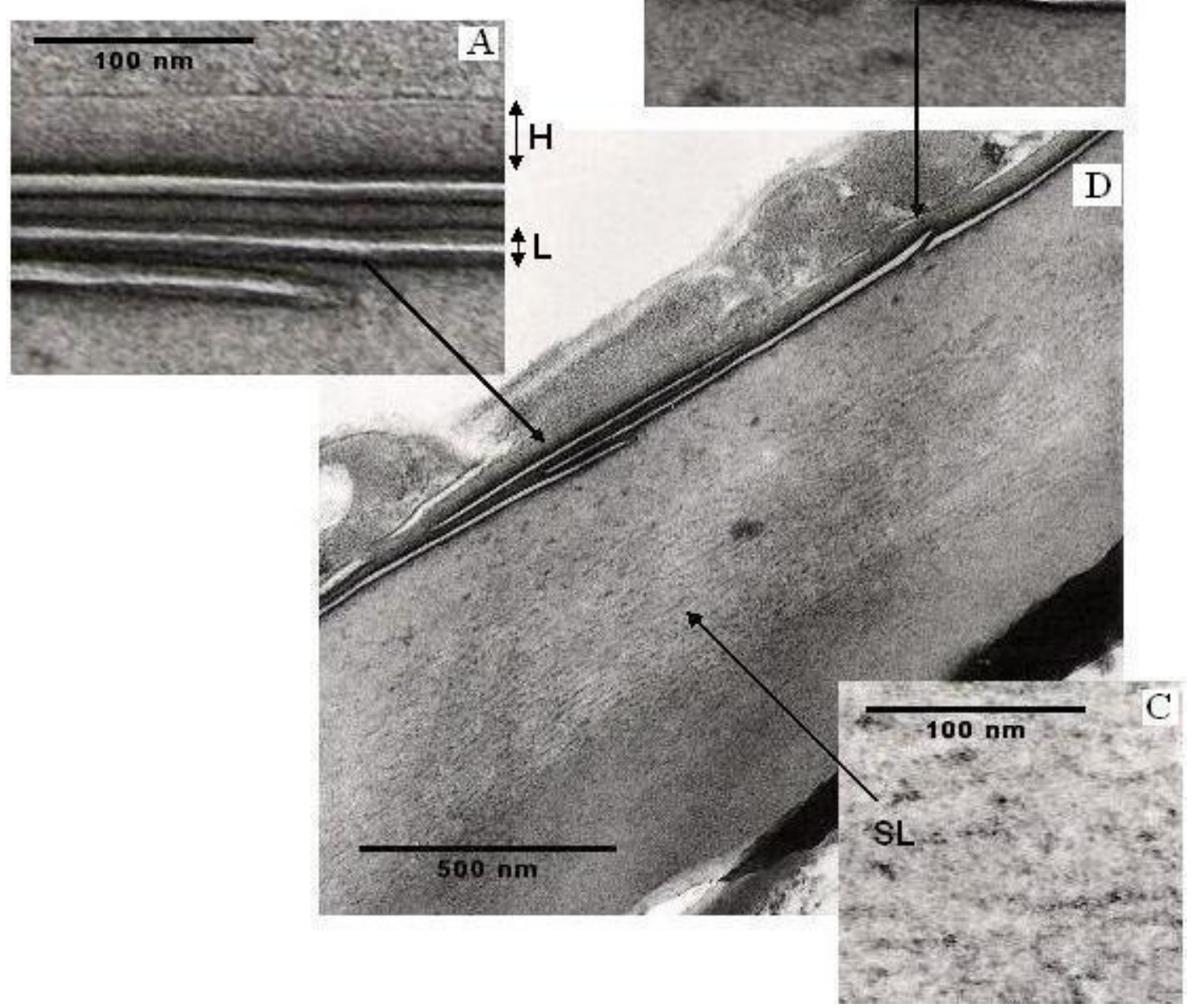

Figura 33 - Corte ultrafino- Perióstraco de Physa, com aproximadamente $1 \mu \mathrm{m}$ de espessura, camada homogênea $(\mathrm{H})$, lamelas densas (L) e a camada sub-lamelar (SL). 

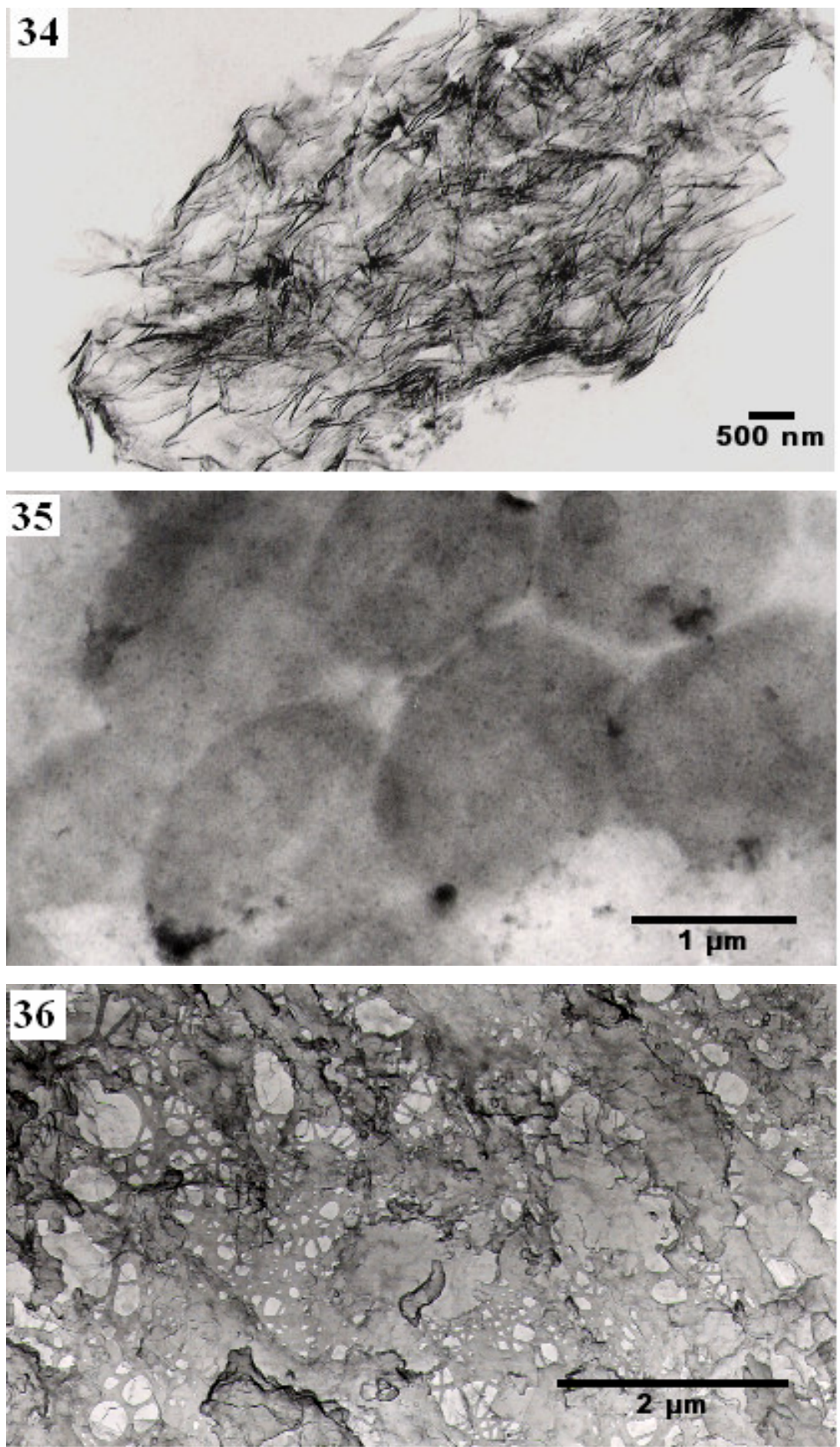

Figura 34 - Material fibroso acumulado na superfície externa do perióstraco. Figura 35 - Discos localizados na matriz orgânica insolúvel de conchas jovens. Figura 36 - Película orgânica contendo perfurações, presentes em conchas adultas - Réplica. 

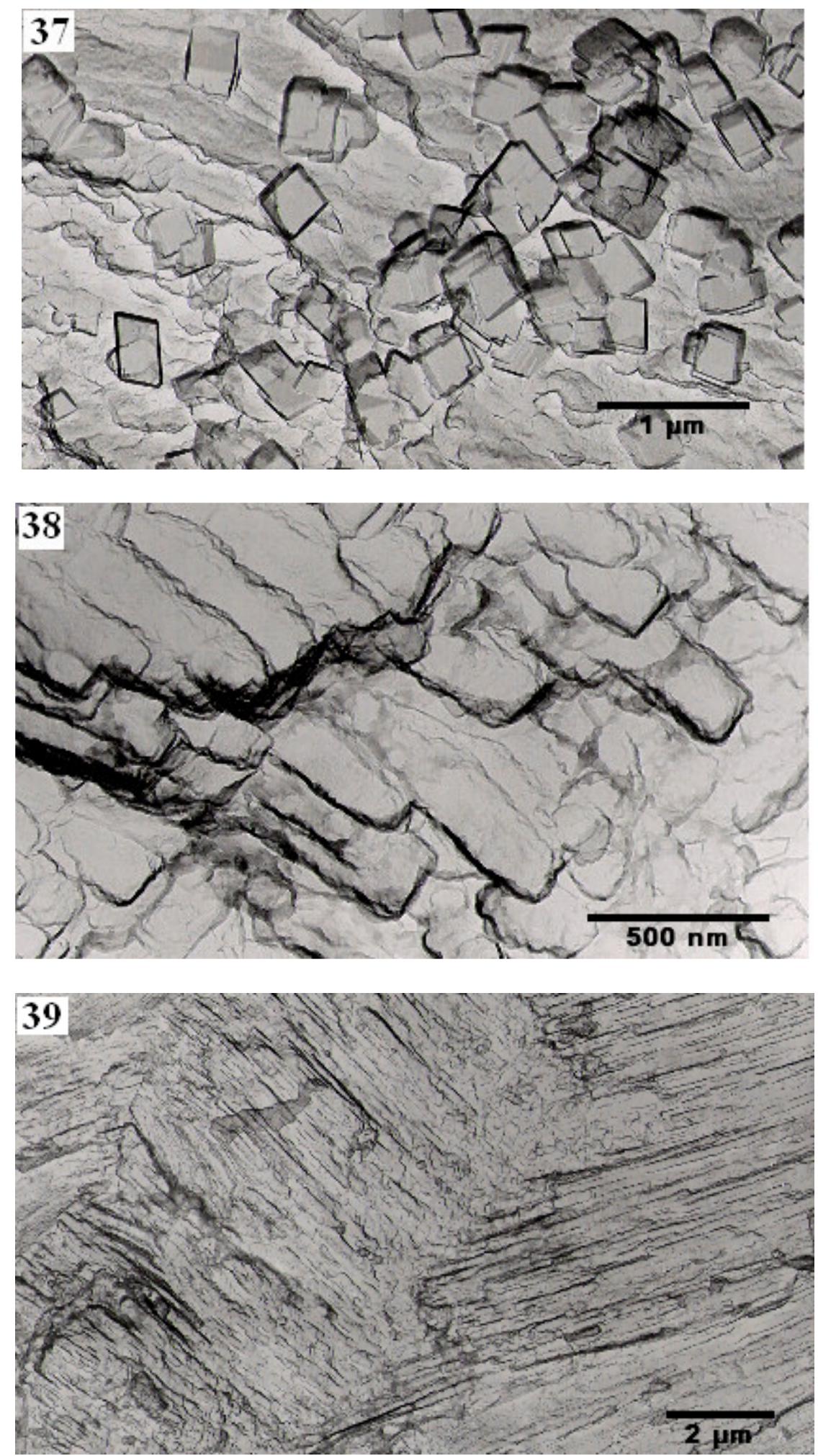

Figura 37- Romboedros de calcita distribuídos randomicamente - Réplica. Figura 38 - Empilhamento de placas - Réplica.

Figura 39 - Lamelas localizadas na parede interna da concha - Réplica. 


\section{Análises quantitativas e qualitativas das composições inorgânica e orgânica da concha do molusco.}

\section{Microscopia de luz (ML)}

A técnica histoquímica do PAS (Periodic Acid-Schiff) identificou a presença de polissacarídeos na matriz orgânica insolúvel (Figura 40A). O ácido periódico oxidou os grupamentos 1-2 glicol, produzindo aldeídos. Estes aldeídos reagiram com a fucsina descorada (reativo de Schiff). Através dessa técnica foi possível visualizar polissacarídeos simples ou associados a proteínas. Várias regiões da amostra apresentaram coloração rosada, resultado positivo, com maior intensidade nos espaços entre as áreas poligonais (Figura 40 B).

As figuras 40 C e D representam o controle, sem coloração. 

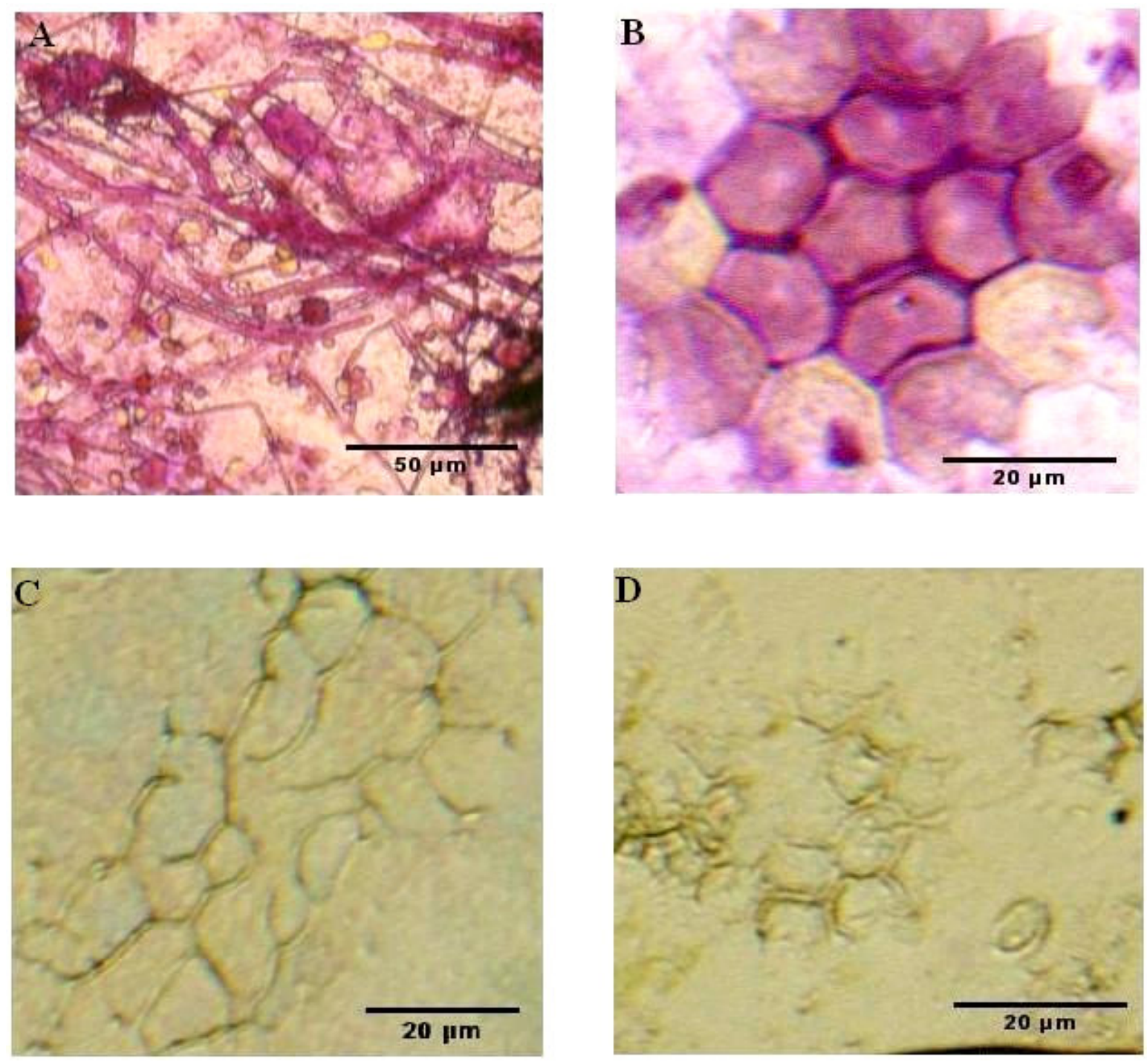

Figura 40 - Imagens de microscopia de luz do material orgânico insolúvel submetido ao teste PAS; A e B resposta positiva ao teste; C e D, controle. Em A observa-se a presença de material fibroso e em $\mathrm{B}$ figuras poligonais. 


\section{Microanálise elementar (EDS)}

A composição química elementar obtida por microanálise de energia dispersiva (EDS) nos MEV e MET (Figuras 41A,B e 42) demonstrou alta concentração de cálcio (Ca), o que confirma a natureza carbonácea da concha. Foram também identificados traços de fósforo $(\mathrm{P})$ e enxofre $(\mathrm{S})$, relacionados à presença de material orgânico, e zinco ( $\mathrm{Zn})$ (Figuras 41A,B).

A microanálise elementar de energia dispersiva no MEV para a concha com $0,5 \mathrm{~mm}$ de altura, mostrou além dos elementos descritos no parágrafo anterior, outros quatro íons inorgânicos (Figura 41B), a saber: alumínio (Al), magnésio $(\mathrm{Mg})$, silício ( $\mathrm{Si})$ e ferro $(\mathrm{Fe})$.

A microanálise elementar realizada no MET (Figura 42) confirmou, além da alta concentração de cálcio, a presença de oxigênio.

O espectro obtido por microanálise elementar no MET correspondente às imagens em forma de discos, registrou a presença de carbono, oxigênio, enxofre e do íon Mn. (Figura 43).

No perióstraco, notou-se a presença de material fibroso com alta concentração de fósforo e cálcio, e oxigênio em menor proporção (Figura 44). O pico atribuído ao cloro é devido ao tratamento da amostra.

Nas Figuras 42, 43 e 44, os picos dos elementos cobre e níquel correspondem à emissão das grades suporte, constituídas desses materiais. 

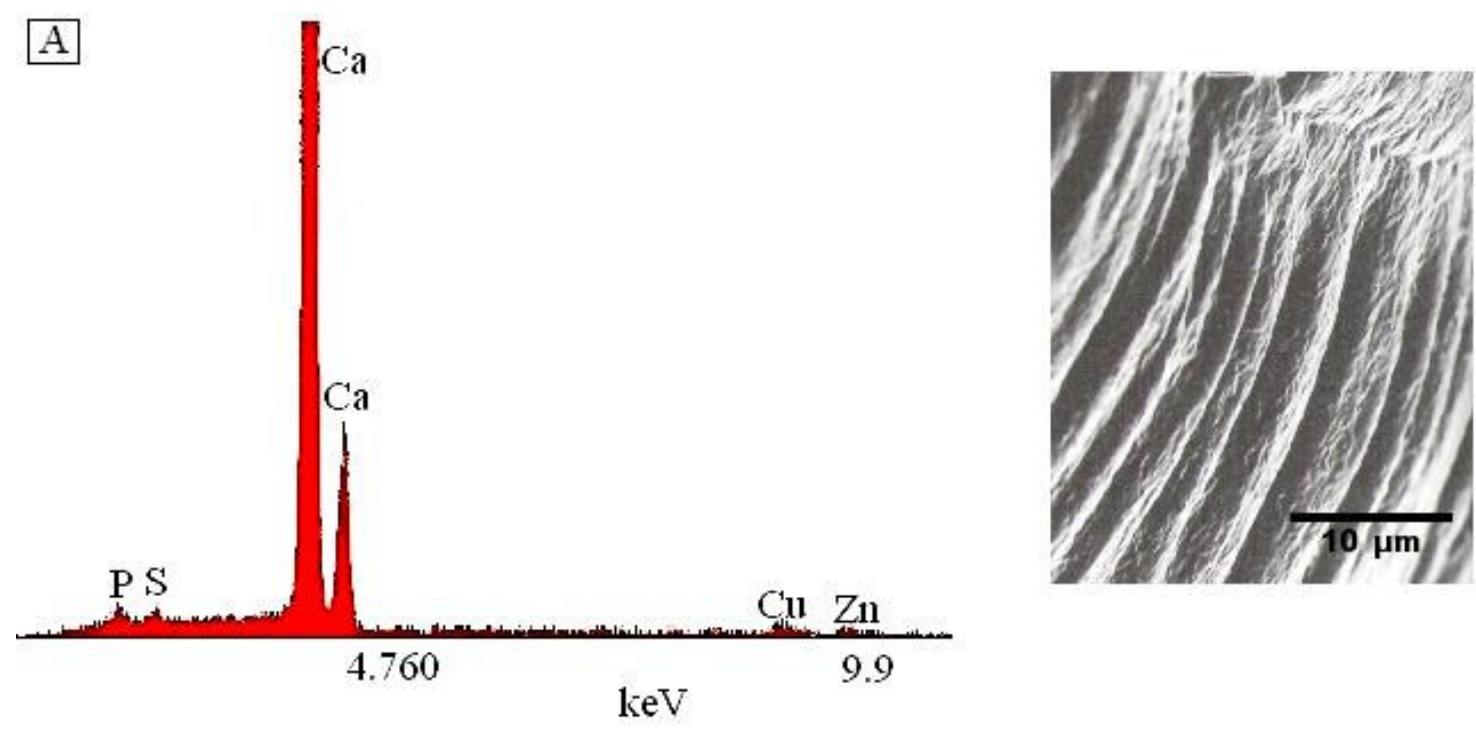

B

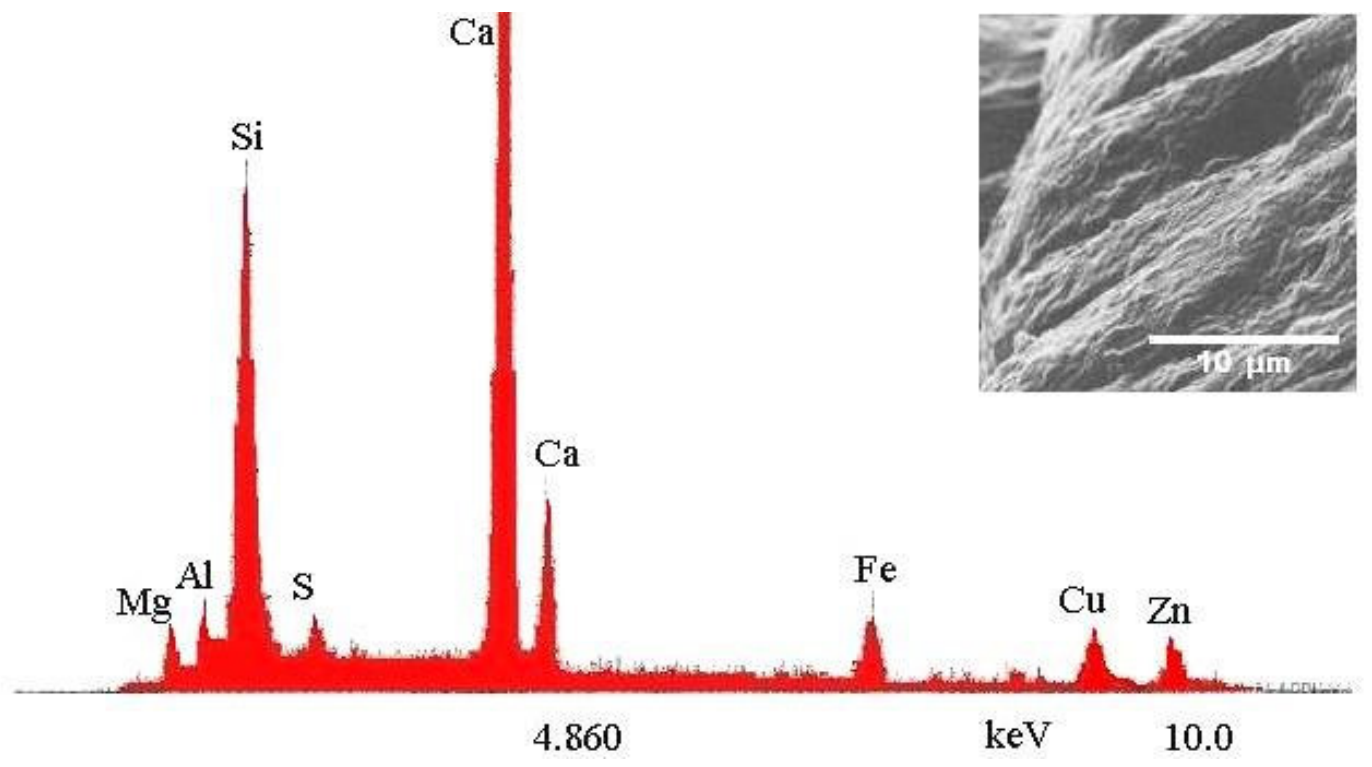

Figura $41 \mathrm{~A}$ - Espectro de EDS/MEV da concha adulta e morfologia da região selecionada. Figura 41 B - Espectro de EDS/MEV de concha jovem e morfologia da região selecionada. 

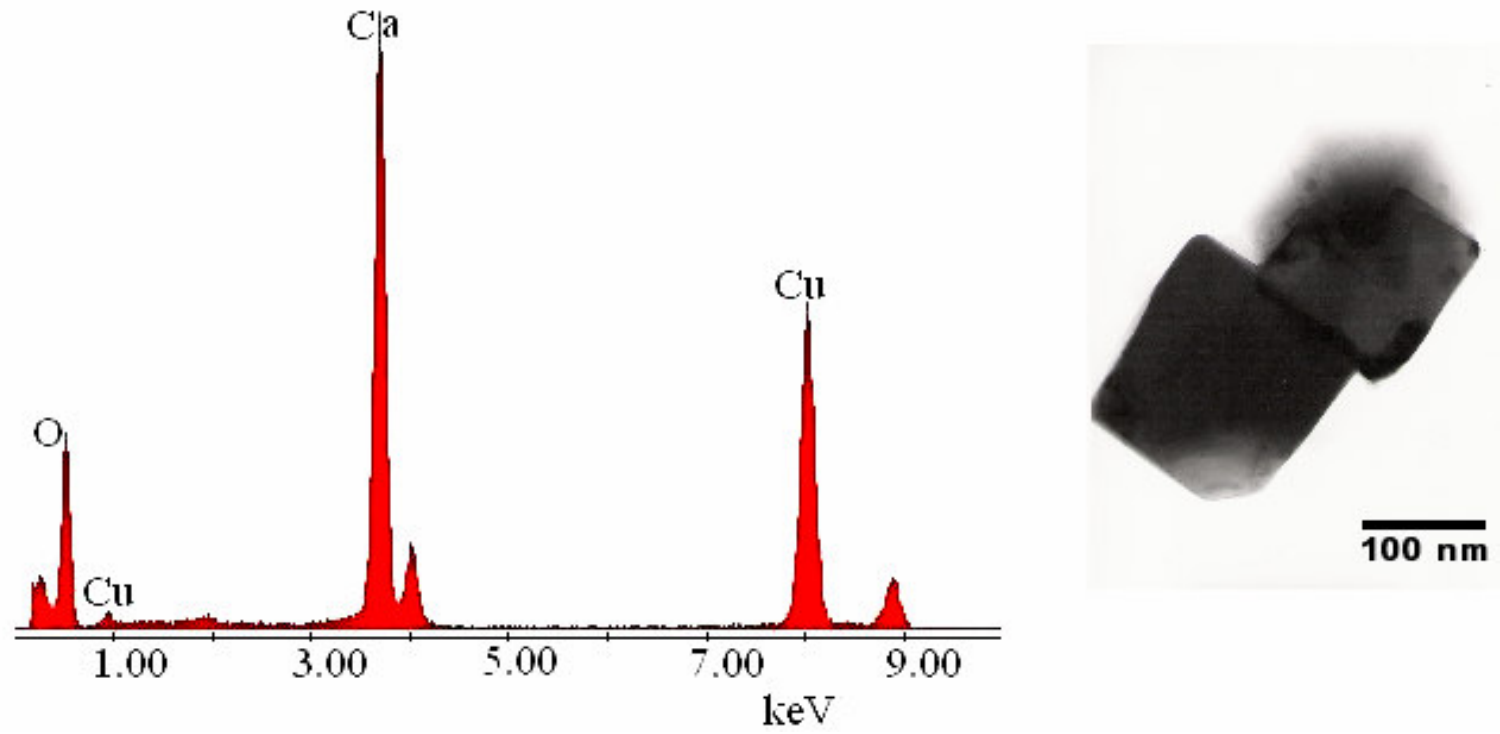

Figura 42 - Espectro de EDS/MET de uma região selecionada para microanálise, contendo cristais.
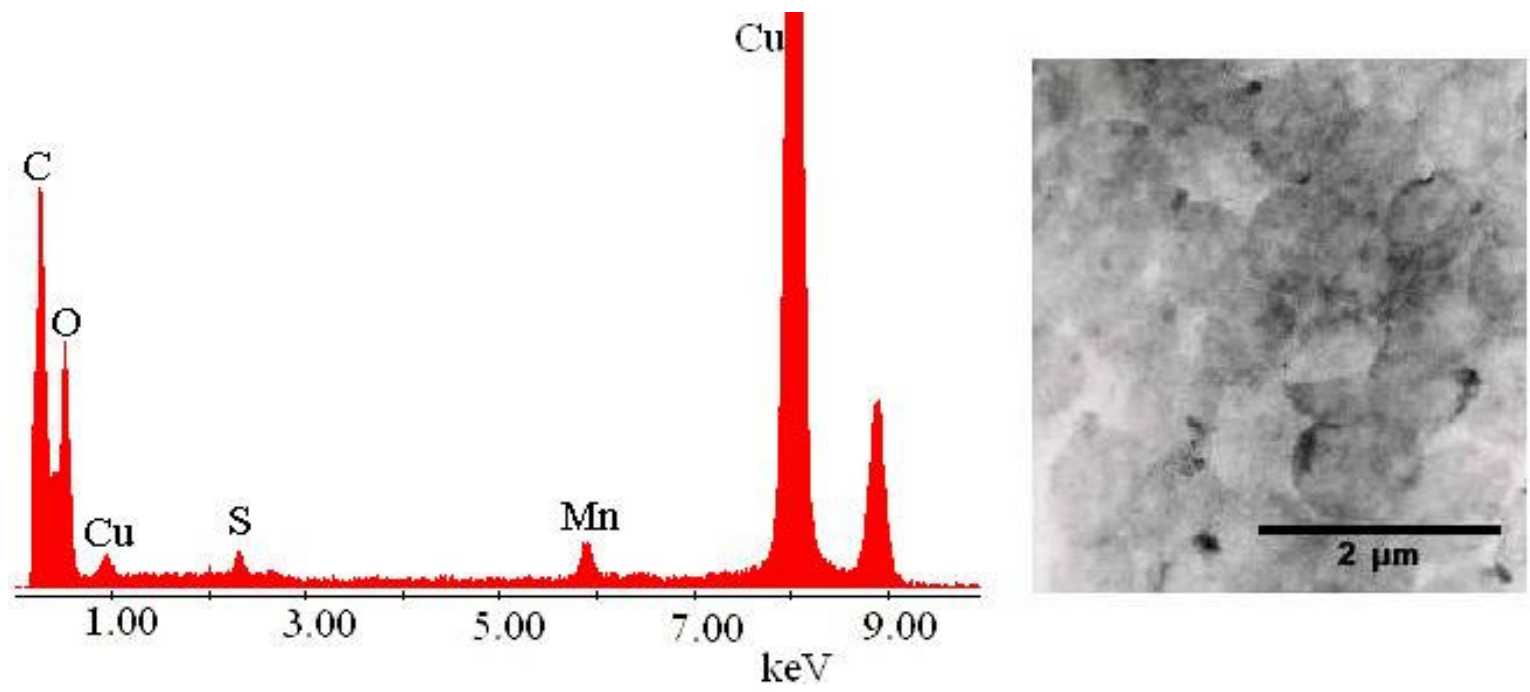

Figura 43 - Espectro de EDS/MET da concha desmineralizada e morfologia da região selecionada para microanálise. 

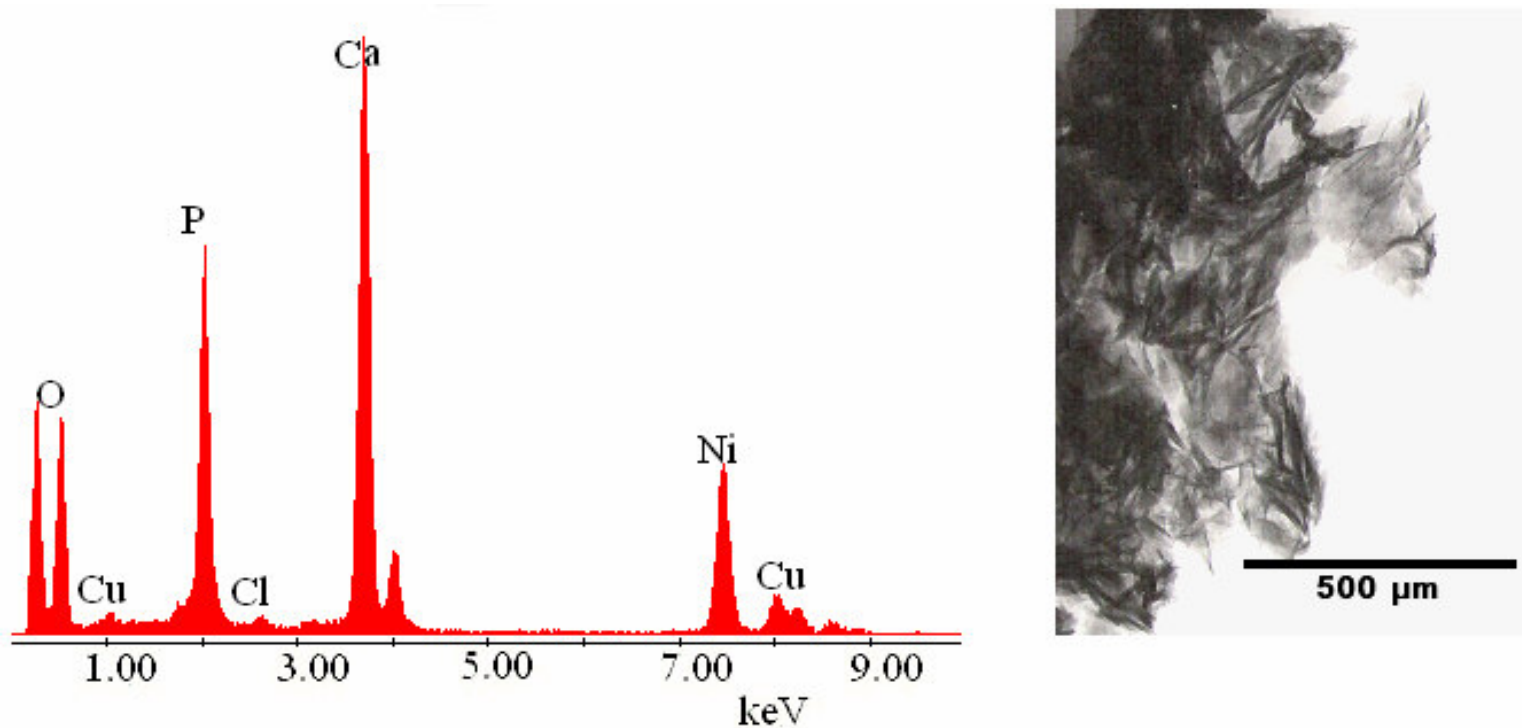

Figura 44 - Espectro de EDS/MET da concha e imagem da região selecionada para microanálise. 


\section{Difração de elétrons de área selecionada (DEAS)}

Cerca de $95 \%$ dos diagramas obtidos e indexados de fragmentos de concha, foram identificados como aragonita, sendo os $5 \%$ restantes relativos à calcita.

Para a indexação da aragonita foram utilizados os parâmetros de rede cristalina ortorrômbica, com a $=5,741 \AA, b=7,968 \AA, c=4,959 \AA$ e $\alpha=\beta=\gamma=90^{\circ}$. Para a calcita, foram utilizados $\mathrm{a}=\mathrm{b}=4,990 \AA \mathrm{A}$ e $\mathrm{c}=17,064 \AA, \alpha=\beta=90^{\circ}$ e $\gamma=120^{\circ}$, que são referentes ao sistema hexagonal.

Nas tabelas 3 e 4 são apresentadas as distâncias inter-planares teóricas $\left(\mathrm{d}_{\text {teórico }}\right)$ e experimentais $\left(\mathrm{d}_{\text {experimental }}\right)$ e as medidas de ângulos teóricos e experimentais referentes às indexações da aragonita e calcita, respectivamente. Os diagramas de difração e a morfologia dos cristais difratados correspondentes, são mostrados nas Figuras 45 e 46. 
Tabela 3- Aragonita

\begin{tabular}{lllll}
\hline $\begin{array}{l}\mathbf{d}_{\text {experimental }} \\
(\mathbf{m m})\end{array}$ & $\begin{array}{l}\mathbf{d}_{\text {teórico }} \\
(\mathbf{m m})\end{array}$ & $\mathbf{h k l}$ & ângulo experimental & ângulo teórico \\
\hline 8,06 & 7,97 & 010 & $0,00^{\circ}$ & $0,00^{\circ}$ \\
5,66 & 5,74 & 100 & $90,00^{\circ}$ & $90,00^{\circ}$ \\
4,59 & 4,66 & 110 & $54,00^{\circ}$ & $54,23^{\circ}$ \\
3,25 & 3,27 & 120 & $34,00^{\circ}$ & $34,76^{\circ}$ \\
2,67 & 2,70 & 210 & $69,00^{\circ}$ & $70,19^{\circ}$ \\
1,87 & 1,89 & 140 & $18,00^{\circ}$ & $19,14^{\circ}$ \\
\hline
\end{tabular}
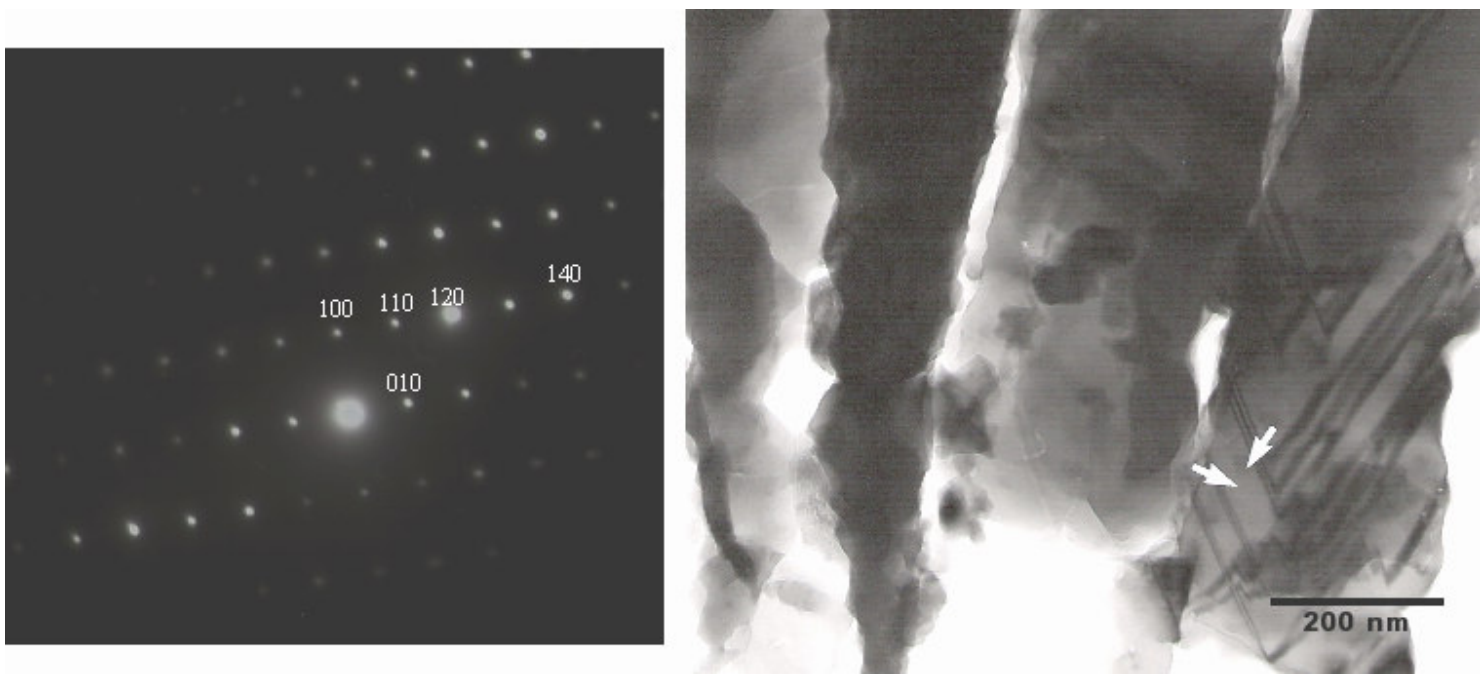

Figura 45 - Diagrama de difração da aragonita e morfologia do cristal selecionado para análise 
Tabela 4- Calcita

\begin{tabular}{ccccc}
\hline $\begin{array}{c}\mathbf{d}_{\text {experimental }}(\mathbf{m m}) \\
(\mathbf{m m})\end{array}$ & $\begin{array}{c}\mathbf{d}_{\text {teórico }} \\
(\mathbf{m m l}\end{array}$ & ângulo experimental & ângulo teórico \\
\hline 4,17 & 4,27 & 004 & $0,00^{\circ}$ & $0,00^{\circ}$ \\
1,16 & 1,19 & 224 & $74,00^{\circ}$ & $73,70^{\circ}$ \\
1,22 & 1,24 & 220 & $90,00^{\circ}$ & $90,00^{\circ}$ \\
1,17 & 1,19 & $22 \overline{4}$ & $106,00^{\circ}$ & $106,03^{\circ}$ \\
1,06 & 1,07 & $22 \overline{8}$ & $120,00^{\circ}$ & $120,03^{\circ}$ \\
\hline
\end{tabular}
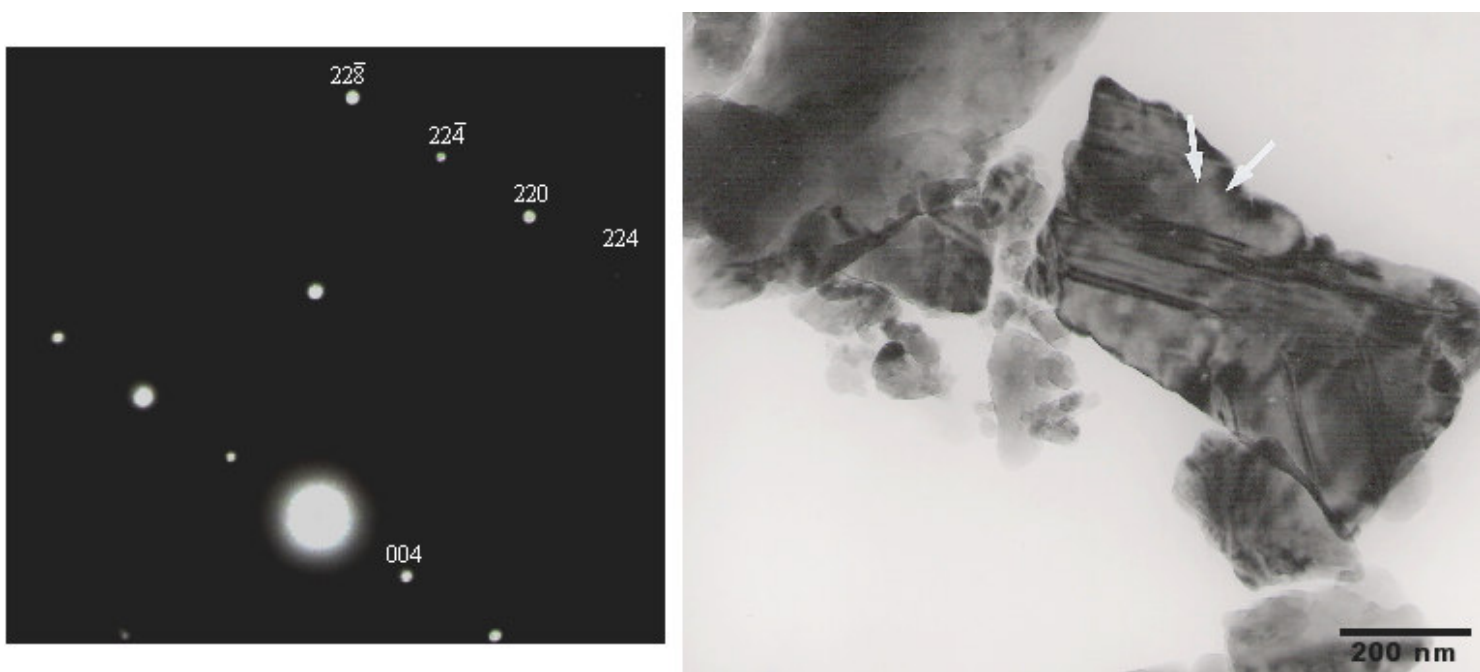

Figura 46 - Diagrama de difração da calcita e morfologia do cristal selecionado para análise. 


\section{Difração de raios-X (DRX)}

O espectro de raios-X das conchas, com os dados refinados pelo método de Rietveld, demonstraram a presença de aragonita e calcita. Na tabela 5 são apresentados os parâmetros utilizados para o refinamento da estrutura das duas fases presentes na amostra:

Tabela 5 - Parâmetros do refinamento Rietveld

\begin{tabular}{llll}
\hline Polimorfismo & Sistema & Espaço de grupo & Parâmetros de cela $(\AA)$ \\
& & & \\
\hline \multirow{2}{*}{ aragonita } & ortorrômbico & Pmcn & $\mathrm{a}=4,963 \AA$ \\
& & $\mathrm{b}=7,970 \AA$ \\
& & $\mathrm{c}=5,748 \AA$ \\
& & $\alpha=\beta=\gamma=90^{\circ}$ \\
& & & $\mathrm{a}=5,029 \AA$ \\
Calcita & romboédrico & $\mathrm{R}-3 \mathrm{c}$ & $\mathrm{b}=5,029 \AA$ \\
& & $\mathrm{c}=16,994 \AA$ \\
& & $\alpha=\beta=90 \mathrm{e} \gamma=120^{\circ}$ \\
\hline
\end{tabular}

Na Figura 47 apresenta-se o resultado do ajuste realizado na região entre $20^{\circ}$ e $95^{\circ}$ da curva de raio-X. A linha contínua representa a curva experimental; os círculos, os dados teóricos e a linha contínua inferior, próxima de zero, o resultado do refinamento.

Todos os picos foram devidamente ajustados. A estrutura final obtida após o refinamento no programa GSAS, produziu bons resultados com $\mathrm{S}=1,816$ (índice de qualidade do refinamento), $\mathrm{R}_{\exp }$ ( valor experimental) $=0,038$ e $\mathrm{R}_{\mathrm{wp}}$ (valor ponderado) $=0,069$. A análise quantitativa das fases, indicou 99,200\% de aragonita e apenas 0,800\% de calcita. 


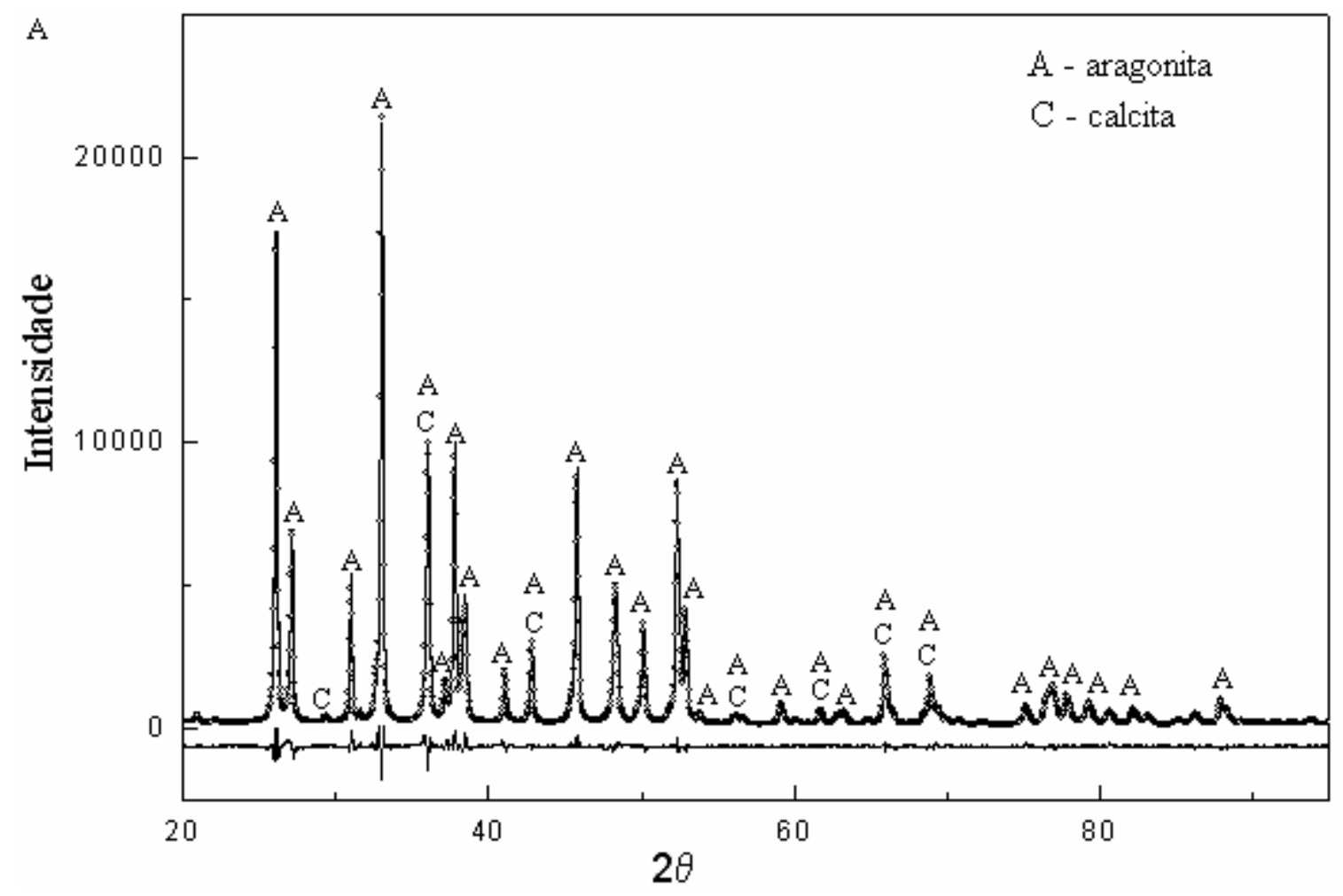

Figura 47 - Espectro de raio-X com os dados refinados pelo método de Rietveld. A linha contínua corresponde aos dados experimentais; os círculos, aos dados teóricos e a linha inferior, próxima de zero, representa a diferença entre os dados experimentais e teóricos. 


\section{Análise por ativação de nêutrons (AAN)}

A tabela 6 contém os resultados quantitativos da determinação dos elementos inorgânicos presentes no material estudado. O resultado foi obtido de uma única determinação; as incertezas foram calculadas, considerando-se os desvios padrão obtidos nas medidas de atividade da amostra padrão.

Tabela 6 - Análise por ativação de nêutrons.

\begin{tabular}{ll}
\hline Elemento & Concentração \\
\hline $\mathrm{Ba}$ & $87,5 \pm 2,0 \mu \mathrm{g} \cdot \mathrm{g}^{-1}$ \\
$\mathrm{Br}$ & $180 \pm 9 \mu \mathrm{g} \cdot \mathrm{kg}^{-1}$ \\
$\mathrm{Ca}$ & $373000 \pm 4000 \mu \mathrm{g} \cdot \mathrm{g}^{-1}$ \\
$\mathrm{Mn}$ & $16,0 \pm 0,2 \mu \mathrm{g} \cdot \mathrm{g}^{-1}$ \\
$\mathrm{Na}$ & $1636 \pm 23 \mu \mathrm{g} \cdot \mathrm{g}^{-1}$ \\
$\mathrm{Sr}$ & $1384 \pm 4 \mu \mathrm{g} \cdot \mathrm{g}^{-1}$ \\
$\mathrm{Zn}$ & $4,90 \pm 0,08 \mu \mathrm{g} \cdot \mathrm{g}^{-1}$ \\
\hline
\end{tabular}

\section{Cromatografia (CLAE)}

Na tabela 7 é apresentado o conteúdo em aminoácidos presentes na matriz orgânica solúvel, que forneceram valores mensuráveis.

O aminograma obtido indicou a presença de 15 aminoácidos no hidrolisado total, sendo os picos mais intensos atribuídos à glicina (Gly), ácido aspártico (Asp), serina (Ser) e ácido glutâmico (Glu) (Figura 48) . 
Tabela 7 - Conteúdo dos aminoácidos presentes em $50 \mu \mathrm{L}$ da matriz orgânica solúvel.

\begin{tabular}{ll}
\hline Aminoácidos & Conteúdo (nmols) \\
\hline Glicina (Gly) & 5,9862 \\
Serina (Ser) & 4,4279 \\
Ácido aspártico (Asp) & 4,1203 \\
Ácido glutâmico (Glu) & 3,9174 \\
Alanina (Ala) & 2,5365 \\
Treonina (Thr) & 1,6040 \\
Valina (Val) & 1,1115 \\
Leucina (Leu) & 0,4319 \\
\hline
\end{tabular}

O prolina (Pro), isoleucina (Ile), tirosina (Tyr), fenilalanina (Phe), histidina (His), lisina (Lys) e arginina (Arg) apareceram em pequena quantidade, impossibilitando a determinação confiável das concentrações. 


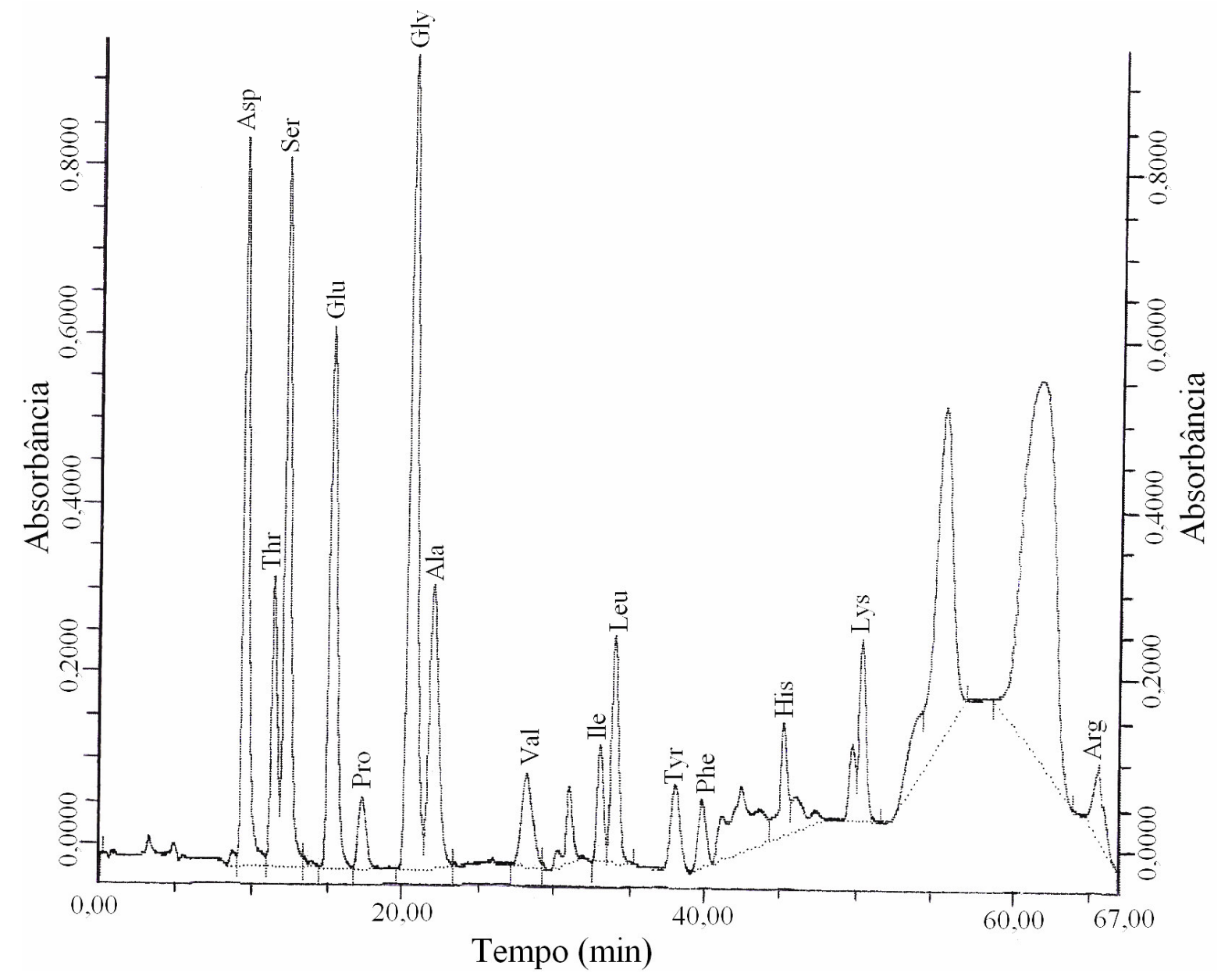

Figura 48 - Aminograma do hidrolisado total da fração orgânica solúvel extraída da concha.

Condições analíticas: tampões citrato, $\mathrm{pH} 3,28$ (0 a 23,8min.), pH 4,25 (23,8 a 36,0min.) e pH 6,30 (36,0 a 66,0min.). Coluna de poliestireno sulfonada da Beckman, 0,40 a 12,00cm. Gradiente de aquecimento de 48 a $65^{\circ} \mathrm{C} \mathrm{em} 11 \mathrm{~min}$., 65 a $77^{\circ} \mathrm{C}$ em $34 \mathrm{~min}$. e $77^{\circ} \mathrm{C}$ por $21 \mathrm{~min}$, fluxo de $0,35 \mathrm{ml} / \mathrm{min}$ e detecção a 440 e $570 \mathrm{~nm}$. 


\section{Espectroscopia de infravermelho (IV)}

Os picos nas regiões de $700 \mathrm{~cm}^{-1}, 712 \mathrm{~cm}^{-1}, 858 \mathrm{~cm}^{-1}, 1476 \mathrm{~cm}^{-1} 1788 \mathrm{~cm}^{-1}$ e de $2916-$ $2522 \mathrm{~cm}^{-1}$, mostram que a concha da Physa é constituída basicamente por $\mathrm{CaCO}_{3}$ (Figura 49). Na região de $3300 \mathrm{~cm}^{-1}$ nota-se uma banda menos intensa, atribuída à amida.

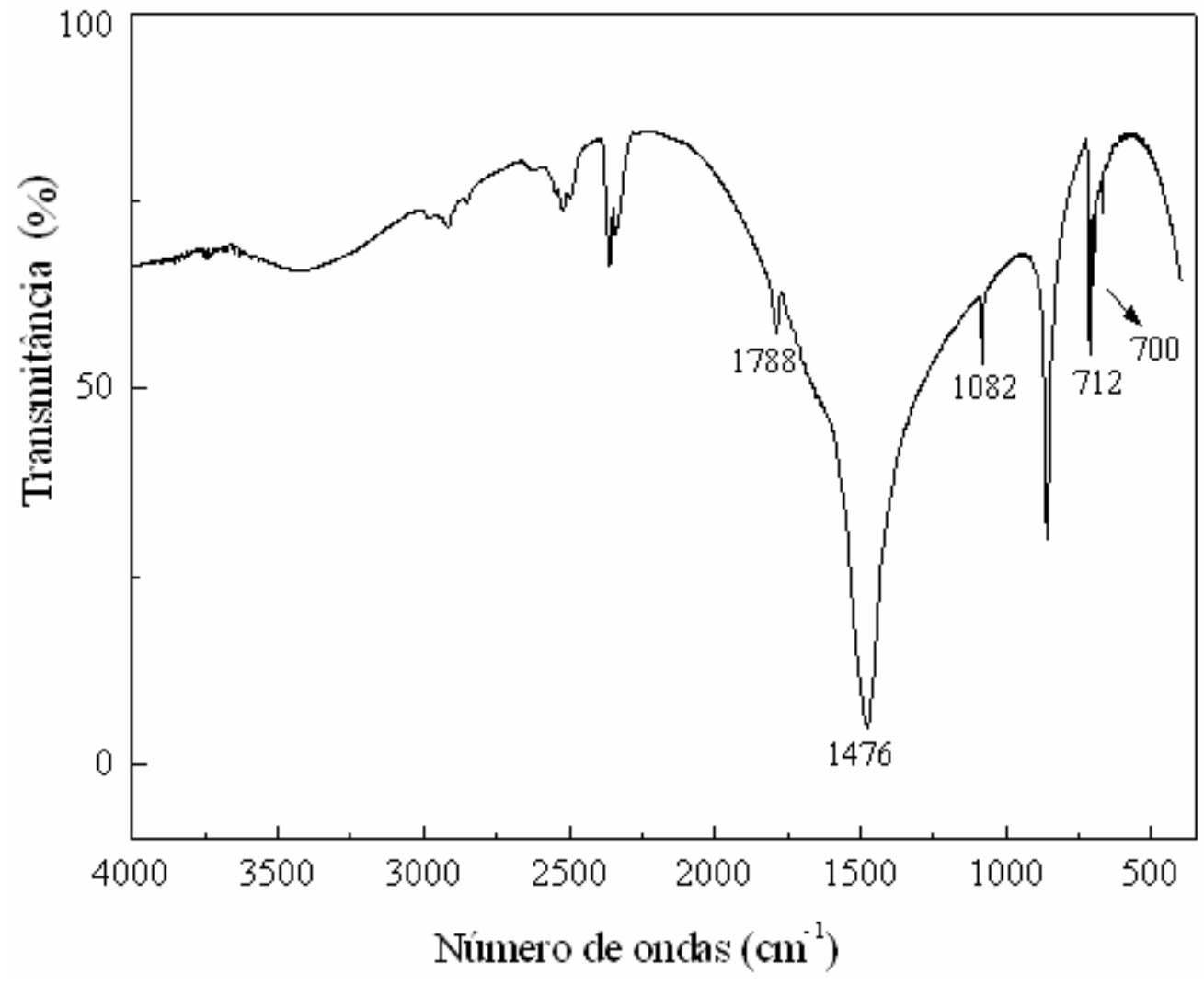

Figura 49 - Espectro de absorção no infravermelho da concha da Physa, sem tratamento químico.

Na Figura 50 é apresentado o espectro de absorção no infravermelho do material orgânico insolúvel extraído da concha. Há picos de absorção na região entre 1800 e $1000 \mathrm{~cm}^{-1}$.

Os picos de absorção em $1690 \mathrm{~cm}^{-1}$ e $1670 \mathrm{~cm}^{-1}$ são atribuídos à vibração da amida I $(\mathrm{C}=\mathrm{O})$; nas regiões entre 1553 e $1530 \mathrm{~cm}^{-1}$ e nas proximidades de $1420 \mathrm{~cm}^{-1}$ observam-se 
bandas atribuídas à amida II; em $1380 \mathrm{~cm}^{-1}$ e $1328 \mathrm{~cm}^{-1}$ há picos de absorção menos intensos atribuídos à vibração da amida III (C-N) ; o pico em $1240 \mathrm{~cm}^{-1}$, está relacionado à vibração das moléculas de sulfato orgânico $\left(\mathrm{SO}_{4}^{2}\right)$; a absorção na região entre 1157 e $1000 \mathrm{~cm}^{-1}$ é devida a presença de polissacarídeos na amostra. É provável que o pico com baixa intensidade em $950 \mathrm{~cm}^{-1}$ esteja associado à presença de fosfato.

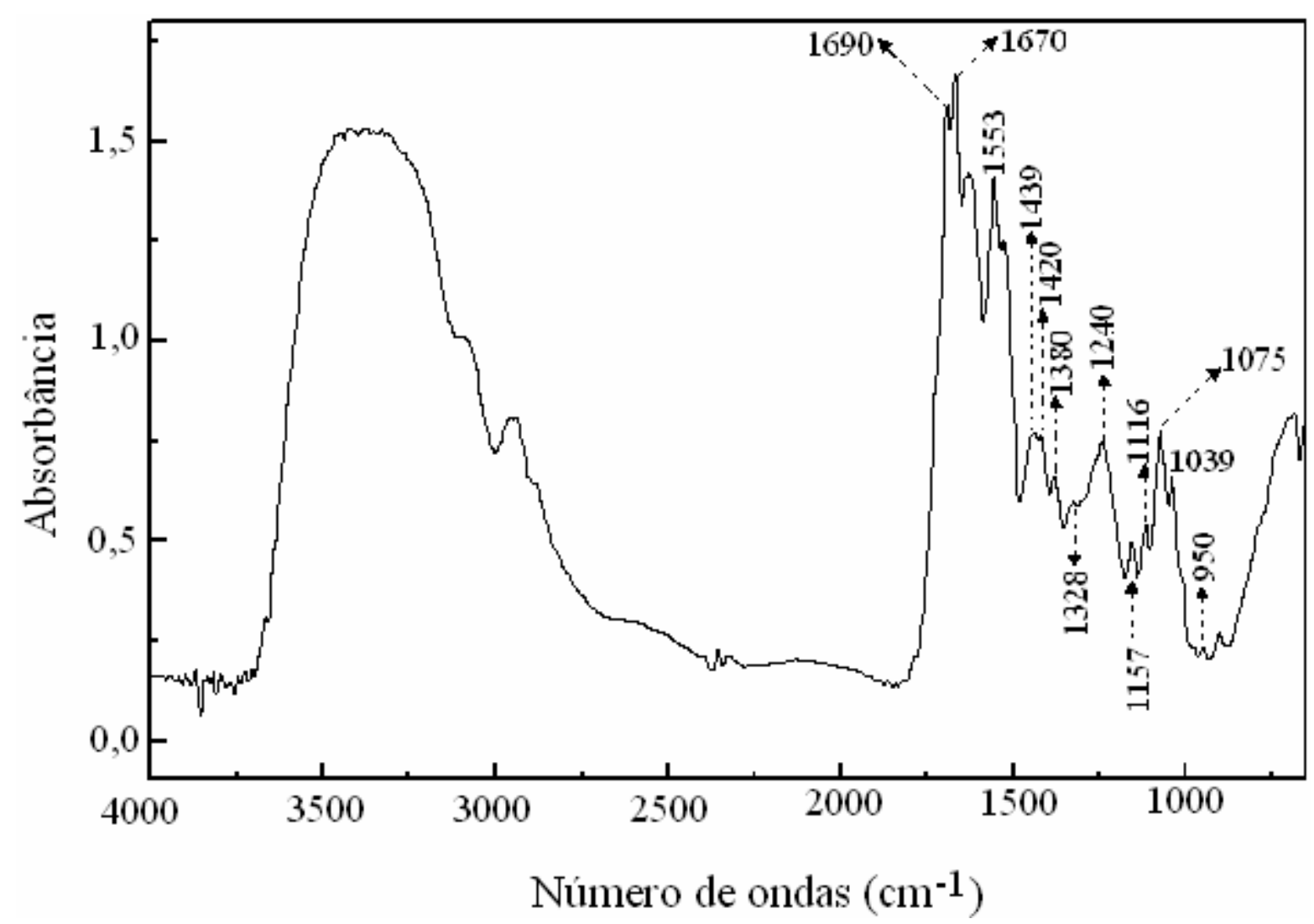

Figura 50 - Espectro de absorção no infravermelho do material orgânico insolúvel extraído da concha. 


\subsection{Parte II - Crescimento de cristais de $\mathrm{CaCO}_{3}$}

\section{Aditivos orgânicos}

A caracterização dos componentes orgânicos solúvel e insolúvel extraídos das conchas e utilizados como aditivos, foi apresentada nas páginas 45, 46 e 56 até 60. Assim, apenas os resultados da caracterização da quitina extraída dos camarões será apresentada neste item.

A Figura 51 corresponde ao espectro de absorção no infravermelho da quitina extraída do exoesqueleto dos camarões. As bandas em torno de 3266 e $3106 \mathrm{~cm}^{-1}$ podem ser atribuídas aos grupos N-H da acetamida em ligações inter-moleculares de hidrogênio; na região de 3000 e de $2881 \mathrm{~cm}^{-1}$, o espectro apresenta bandas de deformação axial de C-H. Nas regiões de $1656 \mathrm{~cm}^{-1}$ (estiramento de $\mathrm{C}=\mathrm{O}$ ) e $1557 \mathrm{~cm}^{-1}$ (deformação N-H) observamse bandas características das amidas I e II; a banda em $1376 \mathrm{~cm}^{-1}$ é atribuída à deformação simétrica de $\mathrm{CH}_{2}$; em $1315 \mathrm{~cm}^{-1}$ a banda é atribuída à amida III, devido à deformação do grupo $\mathrm{CO}-\mathrm{NH}$.

A Figura 52 demonstra que o espectro de raio-X da quitina apresenta baixa cristalinidade, que pode ser atribuída à presença de material amorfo e cristalitos muito pequenos. Observam-se reflexões características da quitina nas proximidades de $2 \theta=9,2^{\circ}$ e $2 \theta=19,3^{\circ}$ (ROBERTS, 1992). A presença dessas reflexões confirma a presença dos domínios cristalinos da quitina nessas regiões. O pico mais estreito, em torno de $30^{\circ}$ deve estar associado à presença de outra fase na amostra. 


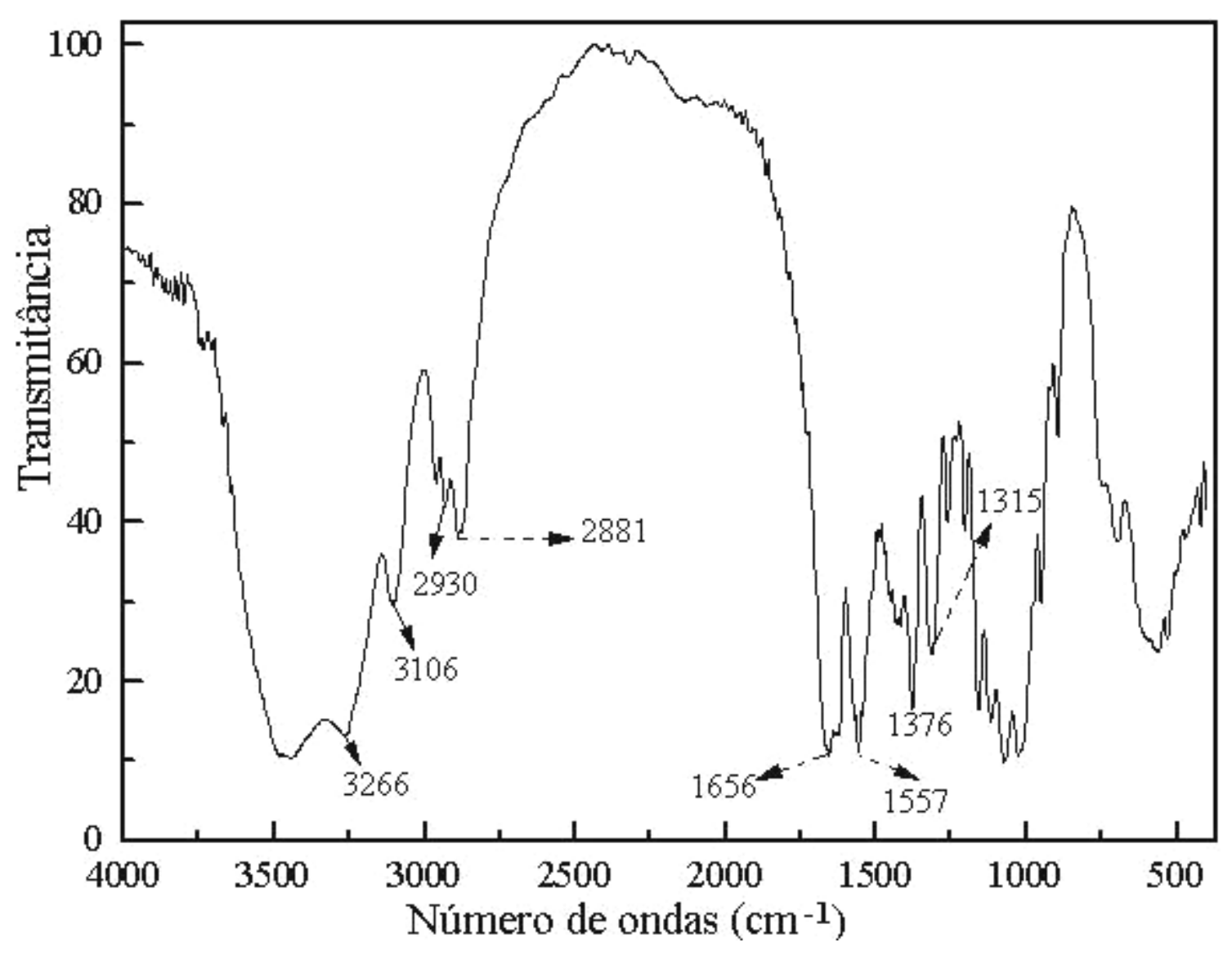

Figura 51- Espectro de absorção no infravermelho, característico da quitina.

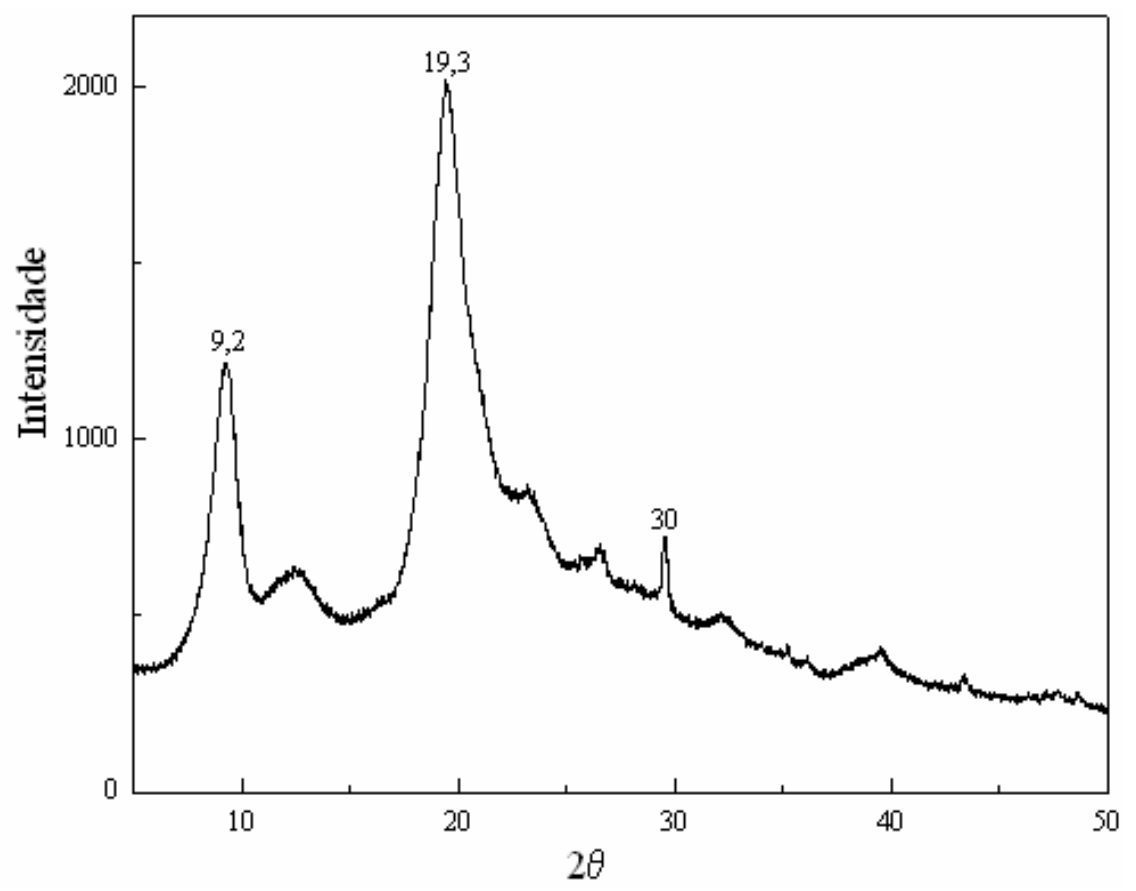

Figura 52- Difratograma da quitina extraída de camarões. 


\section{Morfologia dos cristais de carbonato de cálcio.}

\section{Cristalização de $\mathrm{CaCO}_{3}$ em presença de magnésio (solução controle A)}

$\mathrm{O}$ crescimento de cristais in vitro com adição de magnésio à solução de $\mathrm{CaCO}_{3}$, sem a presença de aditivos (solução de controle), produziu boa distribuição de cristais (Figura 53) com características prismáticas (Figura 54) e esferulíticas em grande quantidade (Figura 55).

A cristalização do $\mathrm{CaCO}_{3}$ na presença das matrizes orgânicas solúvel e insolúvel, não produziu, cristais suficientes para as análises morfológicas e quantitativas em nenhuma das concentrações. .

O ácido aspártico teve efeito inibidor acentuado sobre o crescimento dos cristais (Figura 56). Houve considerável alteração da forma cristalográfica, formando-se prismas ortorrômbicos (Figura 57) e cristais geminados cíclicos (Figura 58).

O ácido glutâmico apresentou caráter inibidor (Figura 59), porém sem significativas alterações na morfologia dos cristais. A Figura 60 ilustra um cristal esferulítico com ligeiras alterações morfológicas, onde as pontas (Figura 61) são facetadas (comparar com a Figura $55)$.

A adição de quitina inibiu a cristalização e induziu a formação de cristais com significativas alterações morfológicas (Figura 62). Nenhuma das formas cristalinas descritas anteriormente foram registradas; formaram-se apenas agregados cristalinos irregulares (Figura 63)

Dentre os aminoácidos utilizados, a glicina (Figuras 64) e a serina (Figuras 65) demonstraram o menor efeito inibidor. Com relação à solução A, não ocorreram alterações morfológicas (Figuras 66 e 67) . Notou-se porém, para a glicina, a formação de alguns 
cristais exóticos, que podem ser descritos como esferulitos que cresceram a partir de um romboedro (Figura 68). 

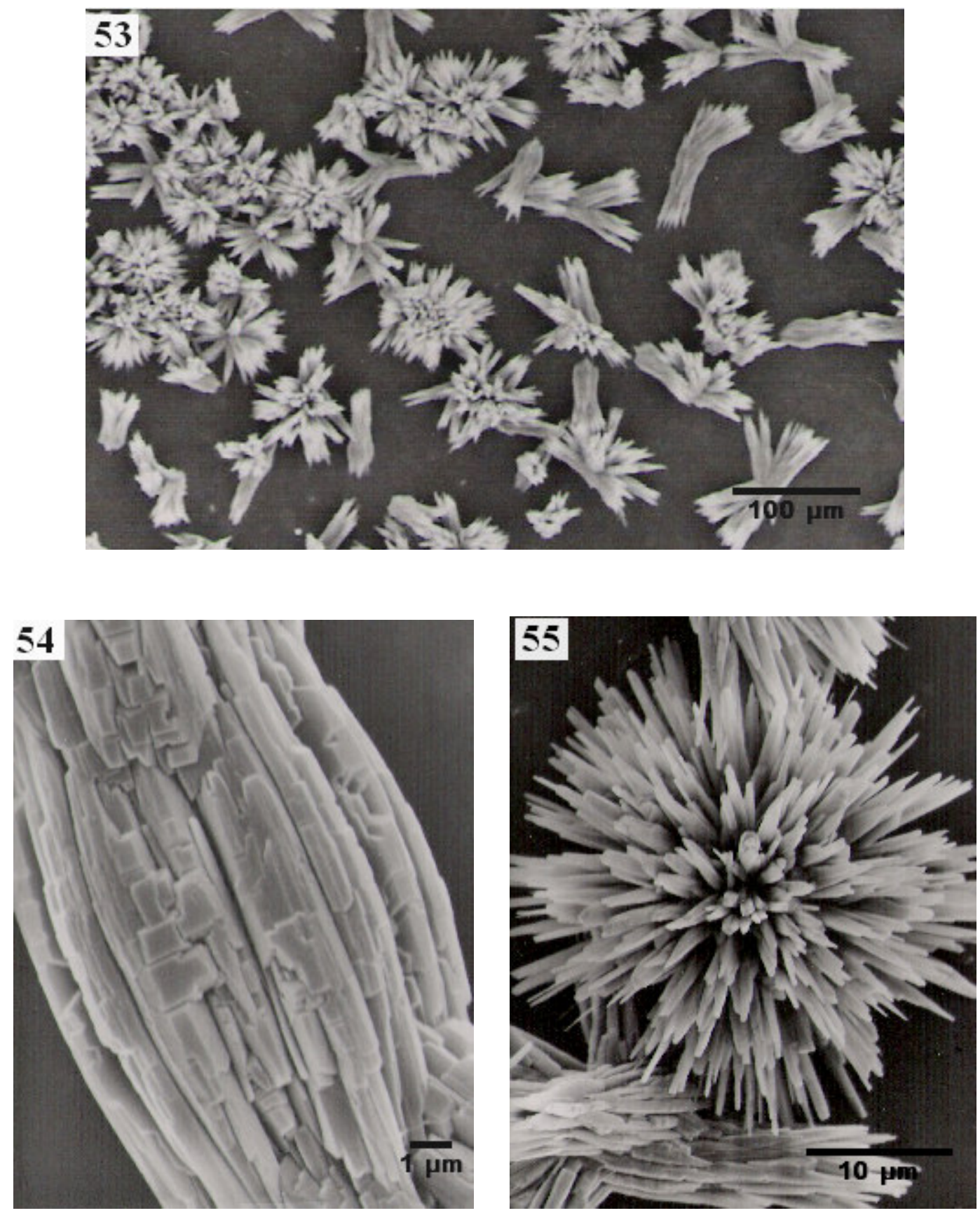

Figuras 53- Cristais de aragonita formados sem a presença de aditivos - Solução controle A. Figura 54 - Cristal poliédrico em detalhe.

Figura 55- Cristal esferulítico em detalhe. 

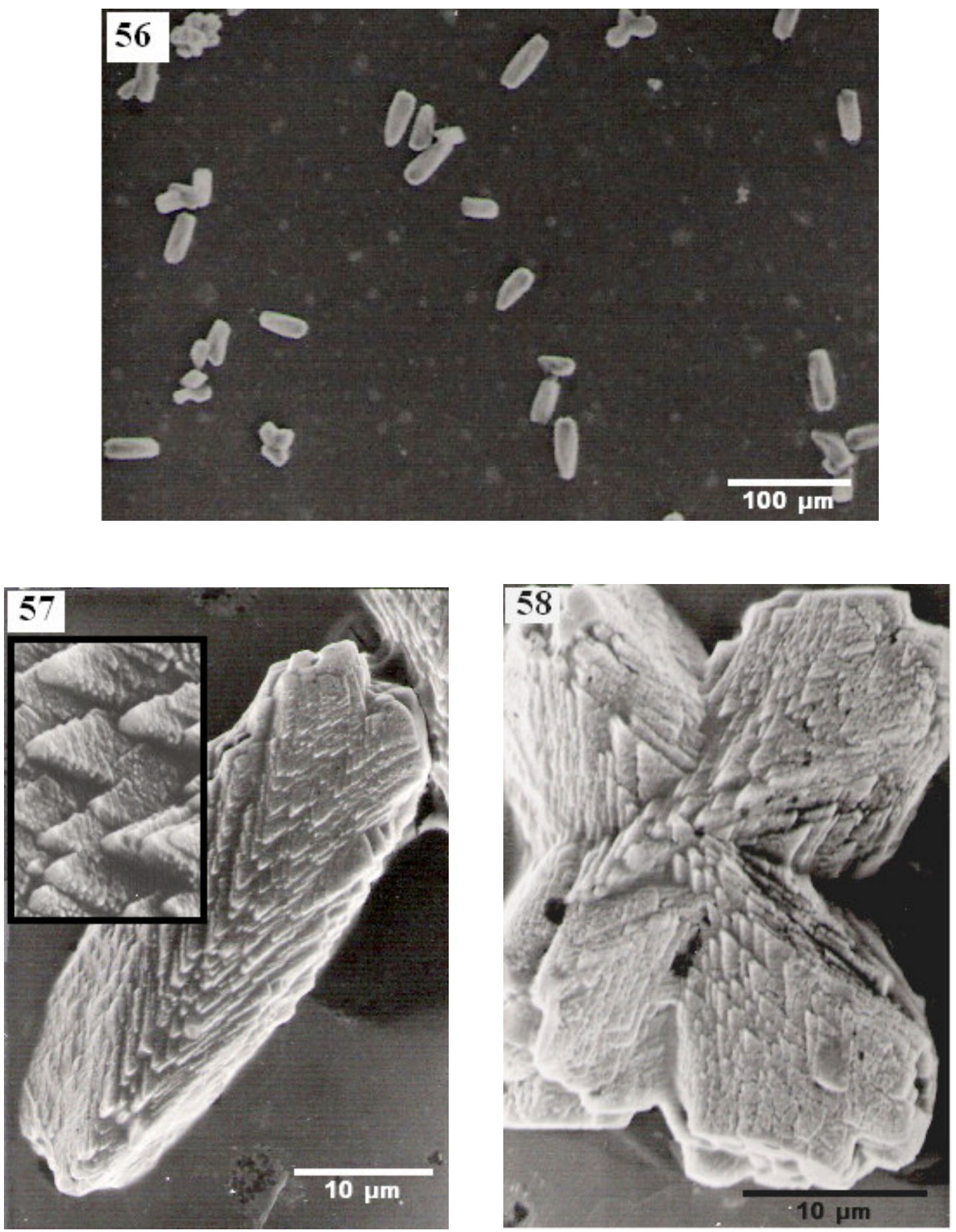

Figura 56 - Cristais formados em presença de ácido aspártico, $0,1 \mathrm{mg} \cdot \mathrm{mL}^{-1}$ Figura 57 - Cristal ortorrômbico.

Figura 58 - Cristal geminado ortorrômbico por penetração. 

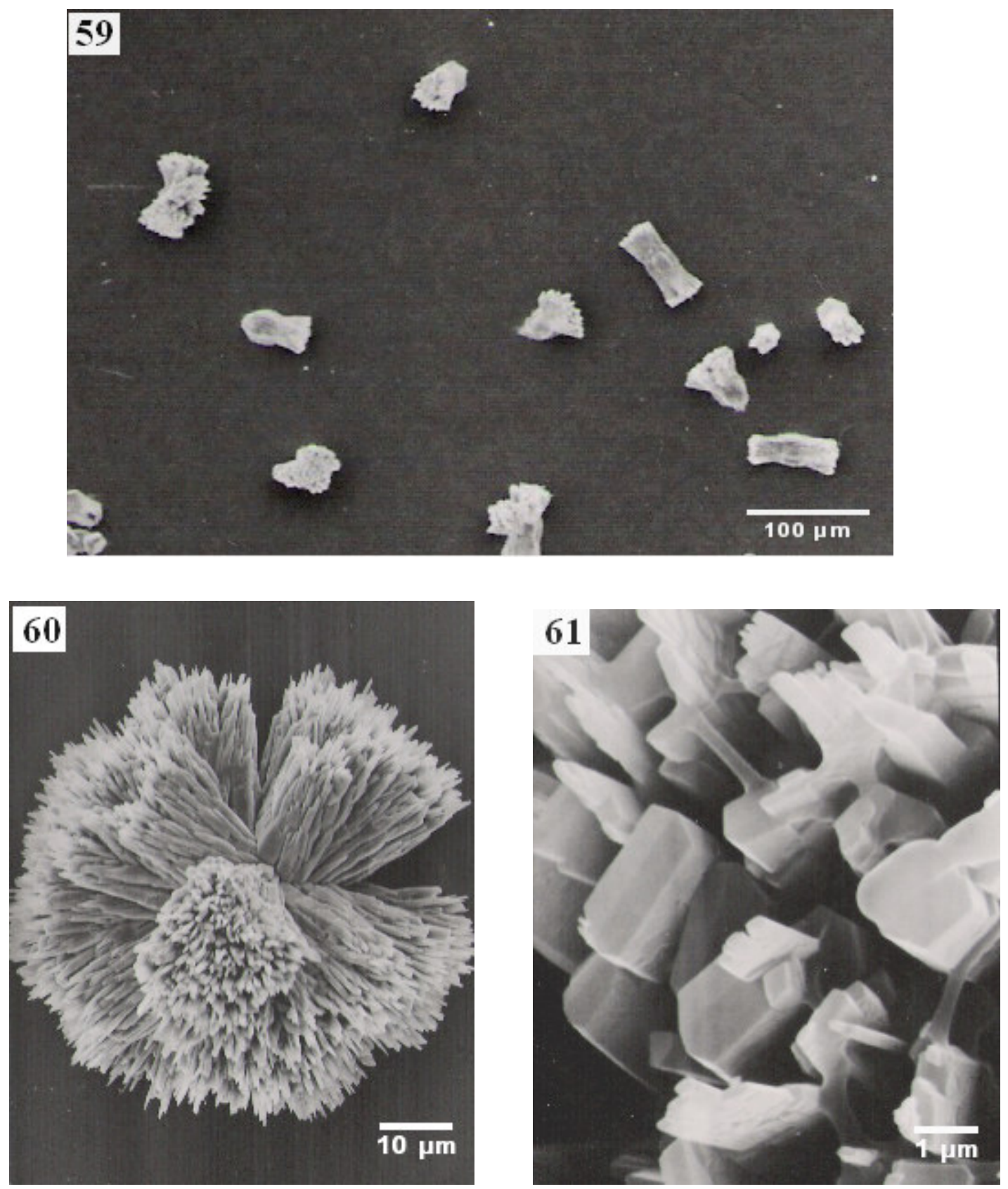

Figura 59 - Cristais formados em presença de ácido glutâmico, $0,1 \mathrm{mg} \cdot \mathrm{mL}^{-1}$ Figura 60 - Esferulito em detalhe.

Figura 61 - Detalhe das pontas do esferulito da Figura 60. 

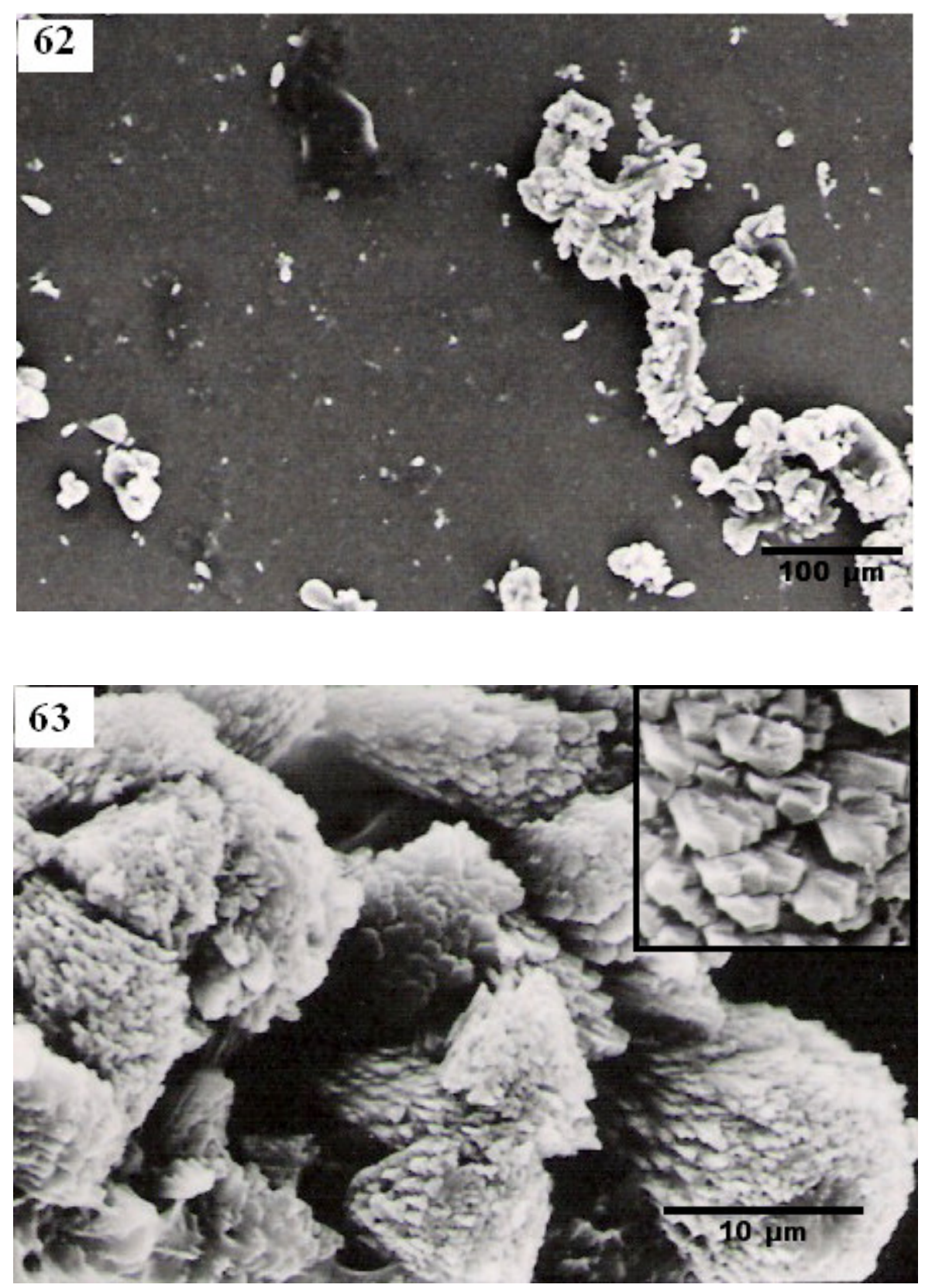

Figura 62 - Aglomerado cristalino formado em presença de $0,1 \mathrm{mg} \cdot \mathrm{mL}^{-1}$ de quitina. Figura 63 - Agregado cristalino em detalhe. 

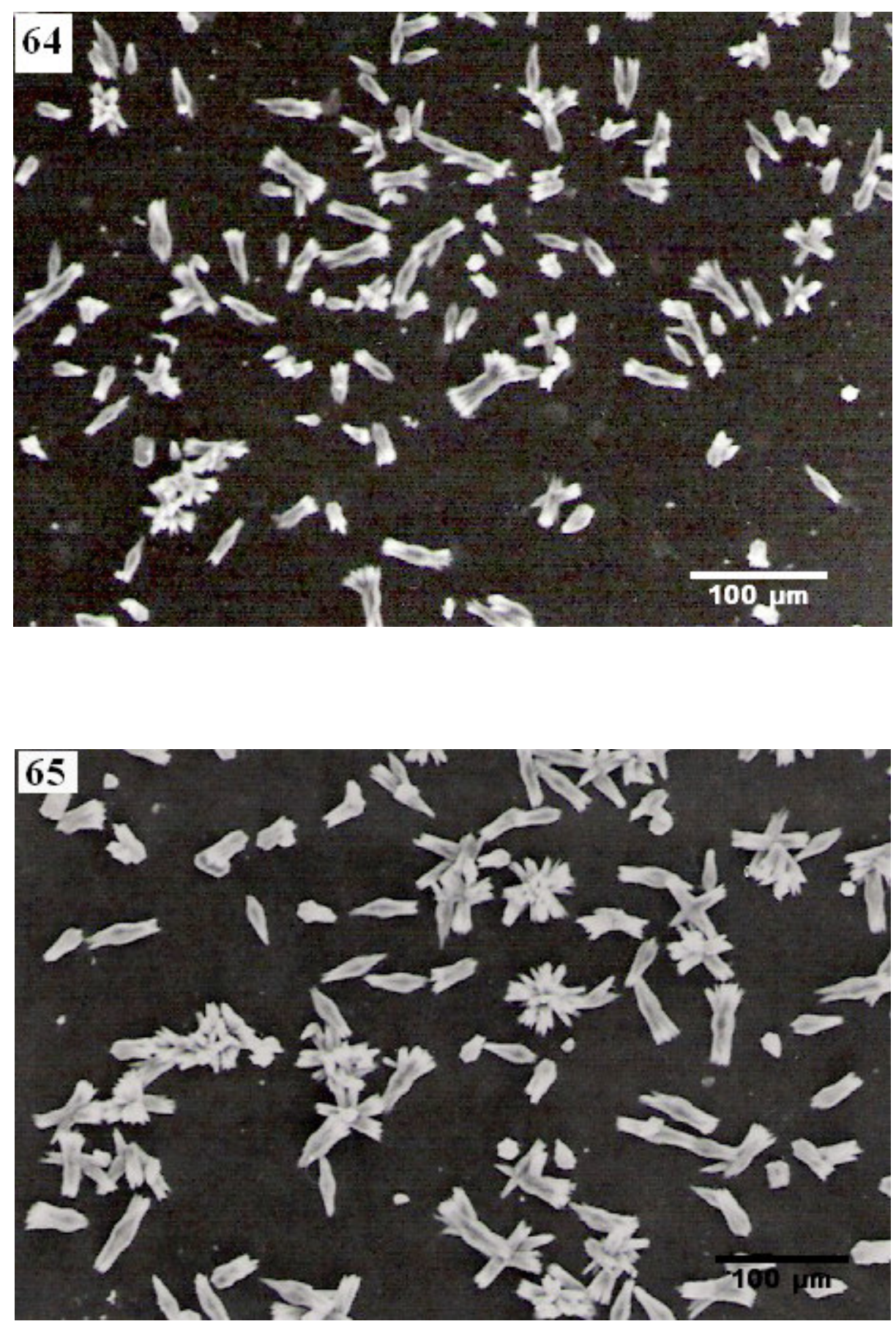

Figura 64 - Cristais formados em presença de glicina, $0,1 \mathrm{mg} \cdot \mathrm{mL}^{-1}$. Figura 65 - Cristais formados em presença de serina, $0,1 \mathrm{mg} \cdot \mathrm{mL}^{-1}$. 

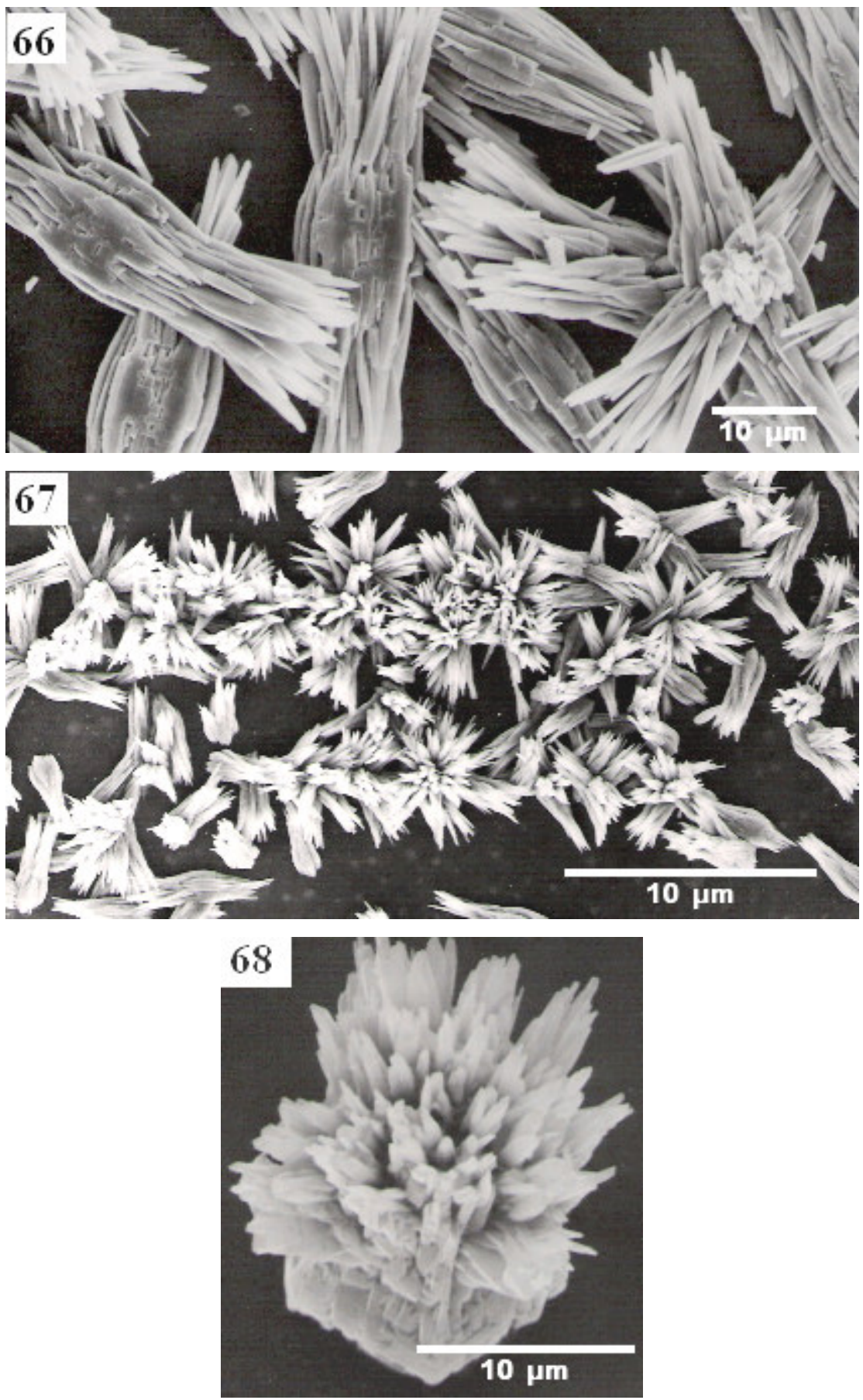

Figura 66 - Cristais aciculares crescidos em presença de $0,1 \mathrm{mg} \cdot \mathrm{mL}^{-1}$ de serina . Figuras 67 - Cristais esferulíticos crescidos em presença de serina. Figura 68 - Cristal crescido em presença de $0,1 \mathrm{mg} \cdot \mathrm{mL}^{-1}$ de glicina. 


\section{Cristalização de $\mathrm{CaCO}_{3}$ sem adição de magnésio (solução controle $\mathrm{B}$ ).}

Nesta etapa do crescimento de cristais in vitro, omitiu-se o magnésio à solução de carbonato de cálcio para que houvesse a predominância de cristais de calcita na solução de controle (sem adição de componentes orgânicos).

A ausência do magnésio propiciou o crescimento de cristais com variações morfológicas (figura 69). Cresceram, em grande quantidade, cristais romboédricos (Figura 70) e em forma de folhas (Figura 71); cristais esferulíticos foram obtidos em pequena quantidade (Figura 72).

Para concentração de $0,1 \mathrm{mg} \cdot \mathrm{mL}^{-1}$ observou-se:

1- O ácido glutâmico, glicina e serina não inibiram a cristalização, nem alteraram a morfológia dos cristais de modo significativo. Cristais romboédricos e lamelares foram predominantes nas soluções contendo ácido glutâmico. Em presença da glicina, a solução produziu cristais hexagonais (Figura 103) e romboédricos.

2- Em presença de ácido aspártico, houve inibição da cristalização de romboedros (Figura 73), ocorrendo a predominância de cristais lamelares, agrupados em "rosetas" (Figura 74). Foram ainda observados cristais radiais (Figura 75) e de cubos com alterações em suas faces (Figura 76).

3- A quitina adicionada inibiu a cristalização (Figura 77). Não foram observados cristais com as características daqueles encontrados na solução de controle. Houve a predominância de cristais com severas alterações em suas faces (Figura 78).

Aumentando-se a concentração dos aditivos para $1 \mathrm{mg}$ por mL observou-se:

1- O ácido aspártico acarretou forte inibição a cristalização (Figura 79), com predominância

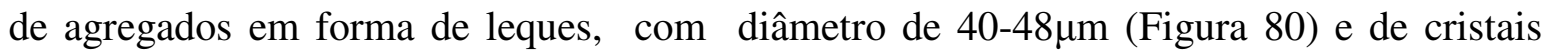


agregados, medindo aproximadamente $50 \mu \mathrm{m}$ de comprimento em pequena quantidade ( Figura 81).

2- A serina mostrou cristais sem variações morfológicas, com 16-18 $\mu \mathrm{m}$ de comprimento (Figura 82). Houve predominância de agregados de placas, mostrado em detalhe na Figura 83; além desse hábito cristalino, somente uma quantidade irrisória de romboedros foi notada.

3- O ácido glutâmico provocou inibição do crescimento dos cristais (Figura 84) e alterações significativas em suas faces ( Figura 85).

4- A quitina inibiu a cristalização (Figura 86); ocorreu apenas, a cristalização de poucos agregados irregulares (Figura 87).

5- A glicina (Figura 88), não reduziu a quantidade de cristais formada porém, alterações morfológicas foram verificadas; notou-se a presença de cristais que se formam a partir de

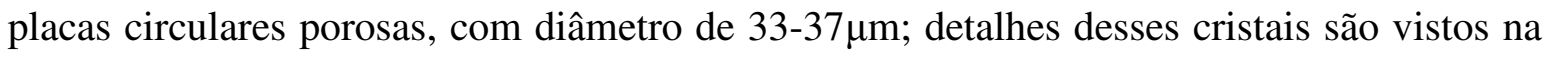
Figura 89.

6- Cristais de carbonato de cálcio crescidos na presença de matéria orgânica insolúvel extraída do molusco, apresentaram características esféricas (Figuras 90), lamelas organizadas em degraus (Figura 91) e em menor quantidade, cristais romboédricos (Figura 92).

7- Em presença de matriz orgânica solúvel, houve a formação de grande quantidade de cristais (Figura 93) com significativas alterações morfológicas. Na figura 94 temos cristais lamelares agrupados em "rosetas" e placas; houve a predominância de placas arranjadas em

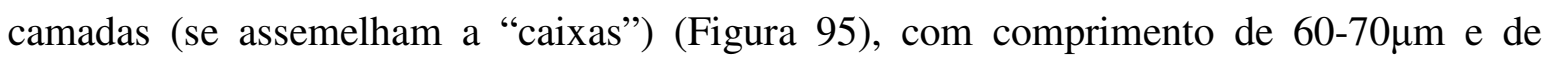
feixes de cristais prismáticos (Figura 96). 


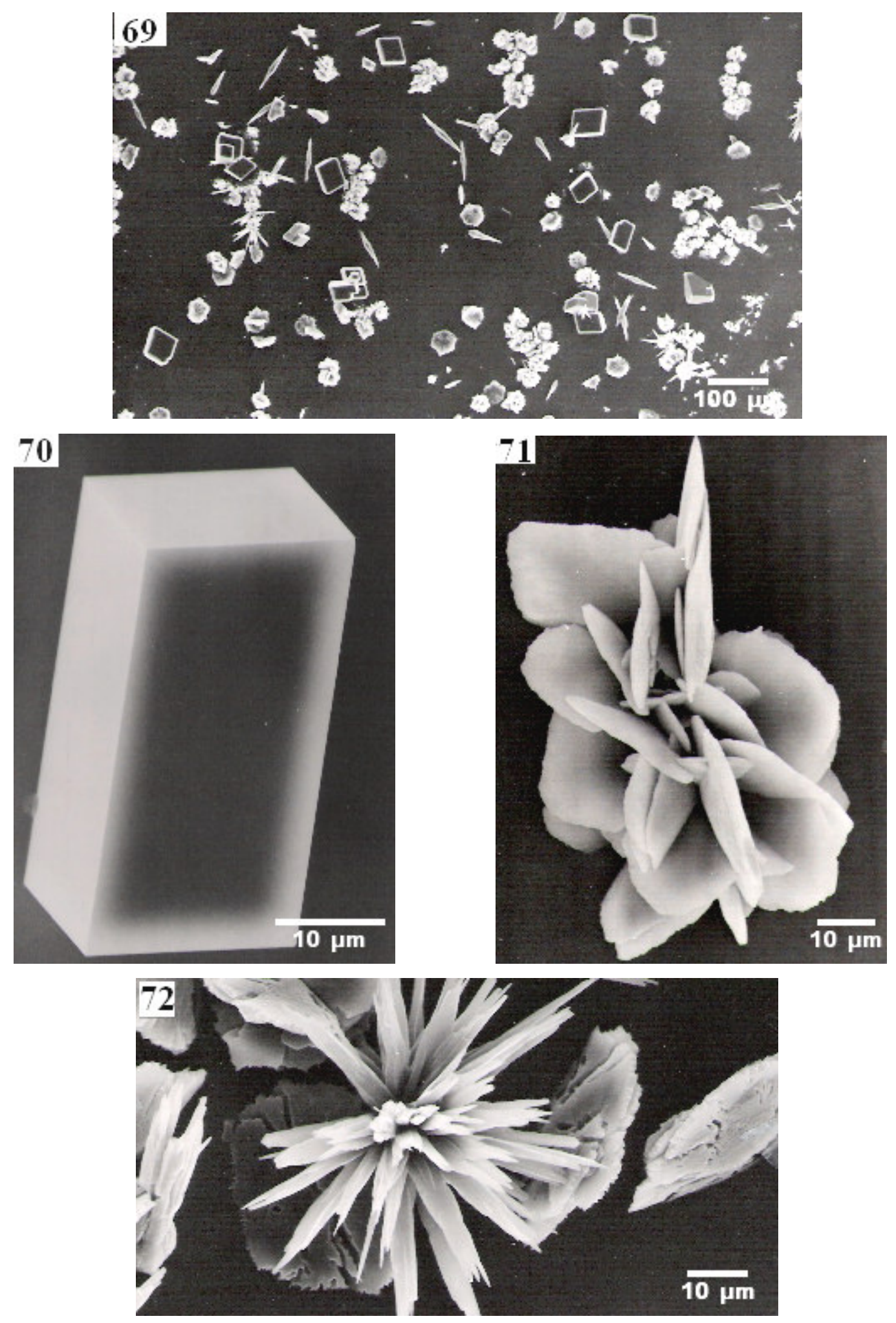

Figura 69 - Cristais formados sem magnésio ou aditivos- Solução controle B. Figura 70- Calcita romboédrica Figura 71 - Agregado de folhas. Figura 72 - Aragonita esferulítica. 

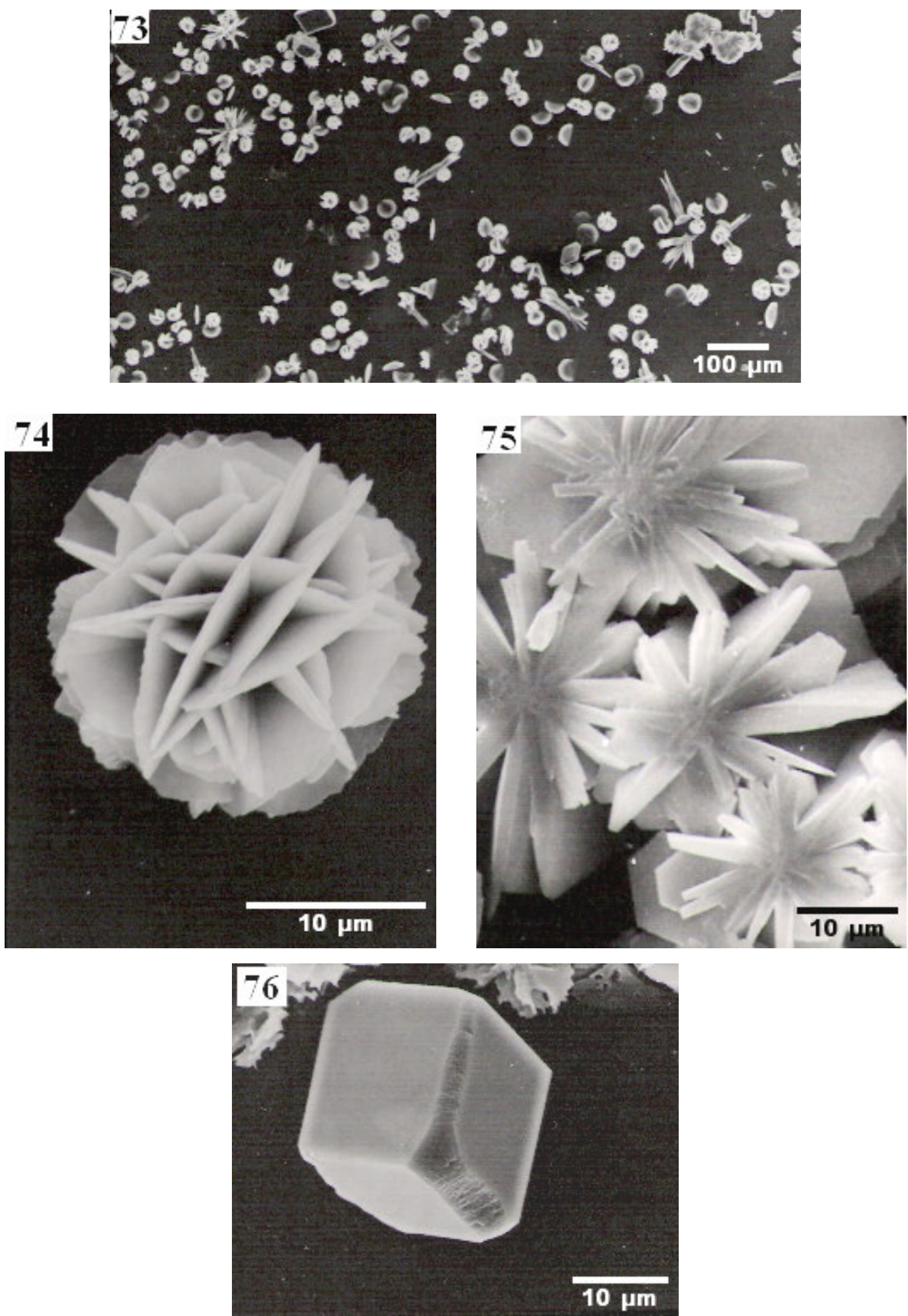

Figura 73 - Cristais formados na solução B em presença de $0,1 \mathrm{mg} \cdot \mathrm{mL}^{-1}$ de ácido aspártico. Figura 74 - Cristais lamelares.

Figura 75 - Grupo radiado de cristais.

Figura 76 - Octaedro combinado. 

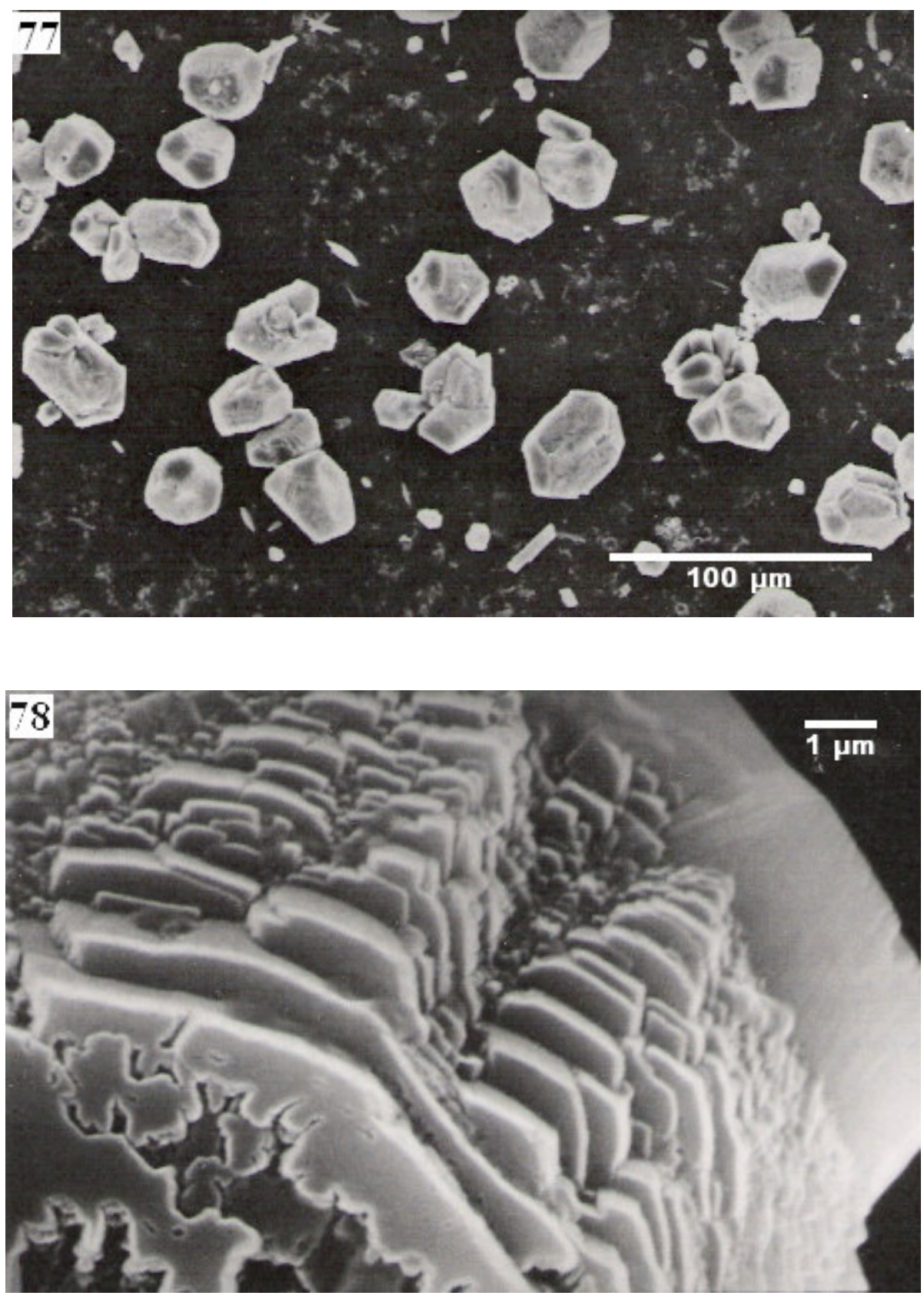

Figura 77 - Cristais formados em presença de $0,1 \mathrm{mg} \cdot \mathrm{mL}^{-1}$ de quitina na solução controle B. Figura 78 - Face de um dos cristais em detalhe com empilhamento de placas. 

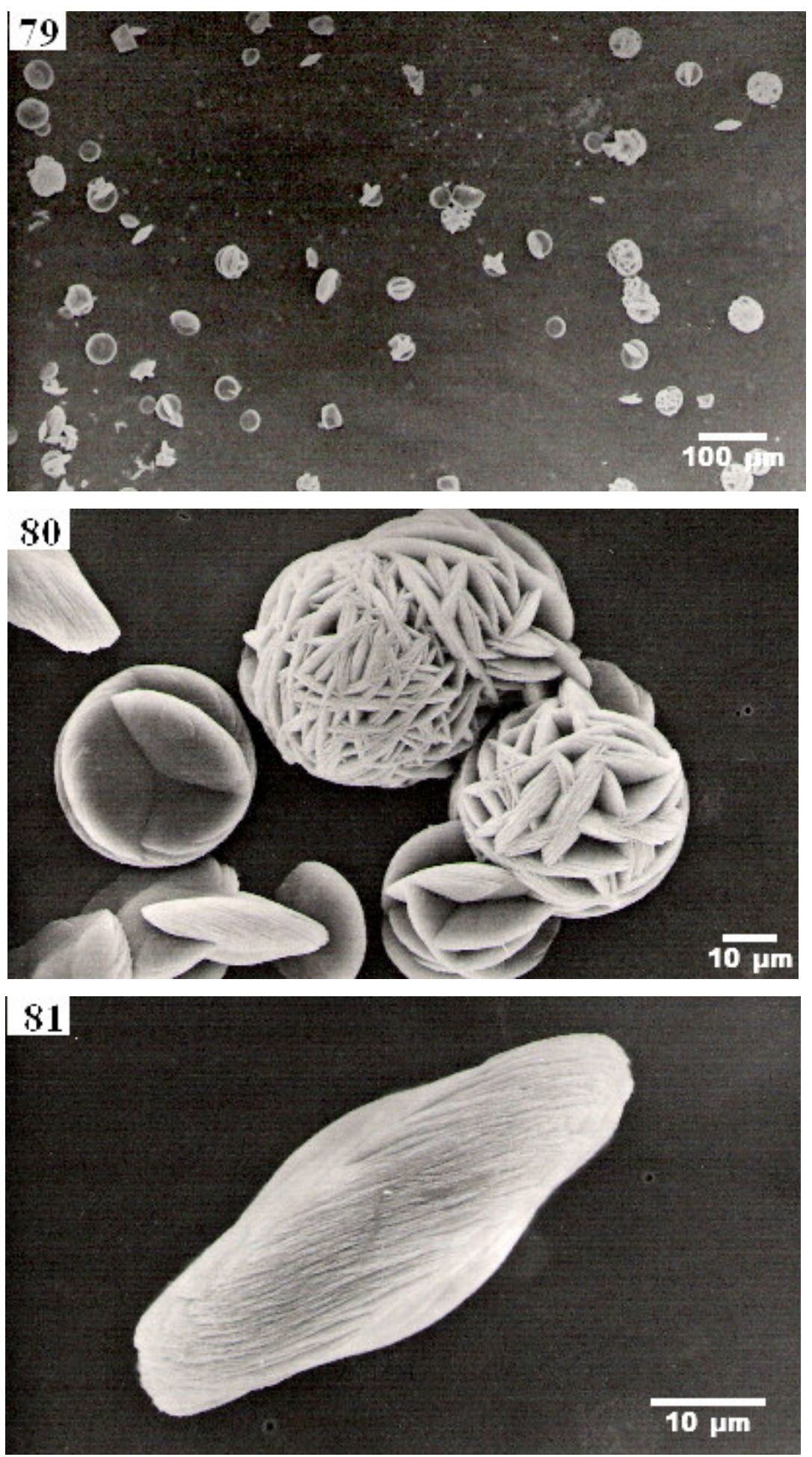

Figura 79 - Cristais formados na solução controle B, em presença de $1 \mathrm{mg} \cdot \mathrm{mL}^{-1}$ de ácido aspártico. Figura 80 - Agregados em forma de leques

Figura 81 - Cristal com $50 \mu \mathrm{m}$ de comprimento. 

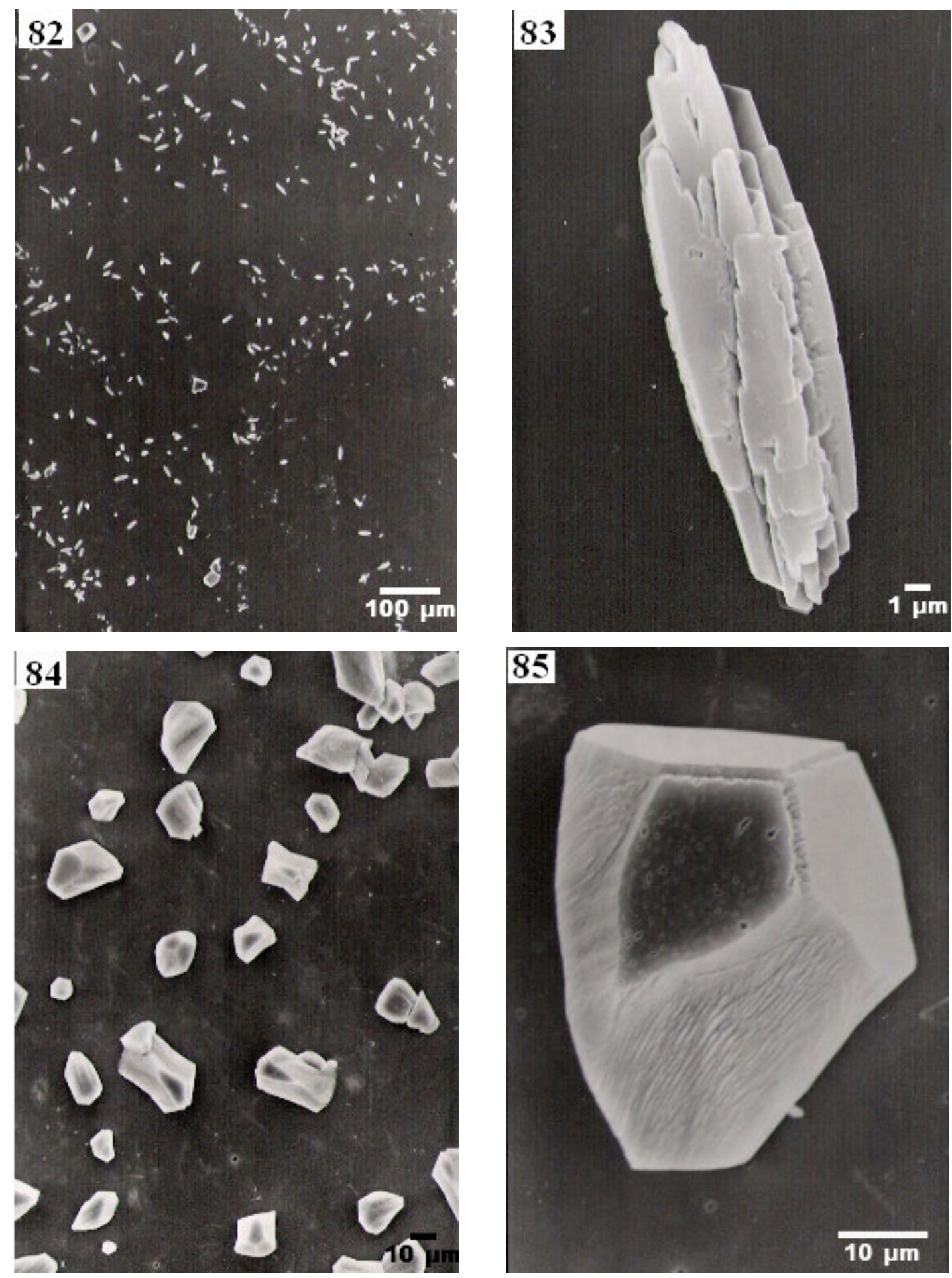

Figuras 82 - Cristais formados na solução controle B, em presença de $1 \mathrm{mg} \cdot \mathrm{mL}^{-1}$ de serina. Figura 83 - Agregado de placas formado em presença de serina..

Figuras 84 - Cristais formados na solução B, em presença de $1 \mathrm{mg} \cdot \mathrm{mL}^{-1}$ de ácido glutâmico. Figura 85 - Cristal com faces irregulares crescido em presença de ácido glutâmico. 

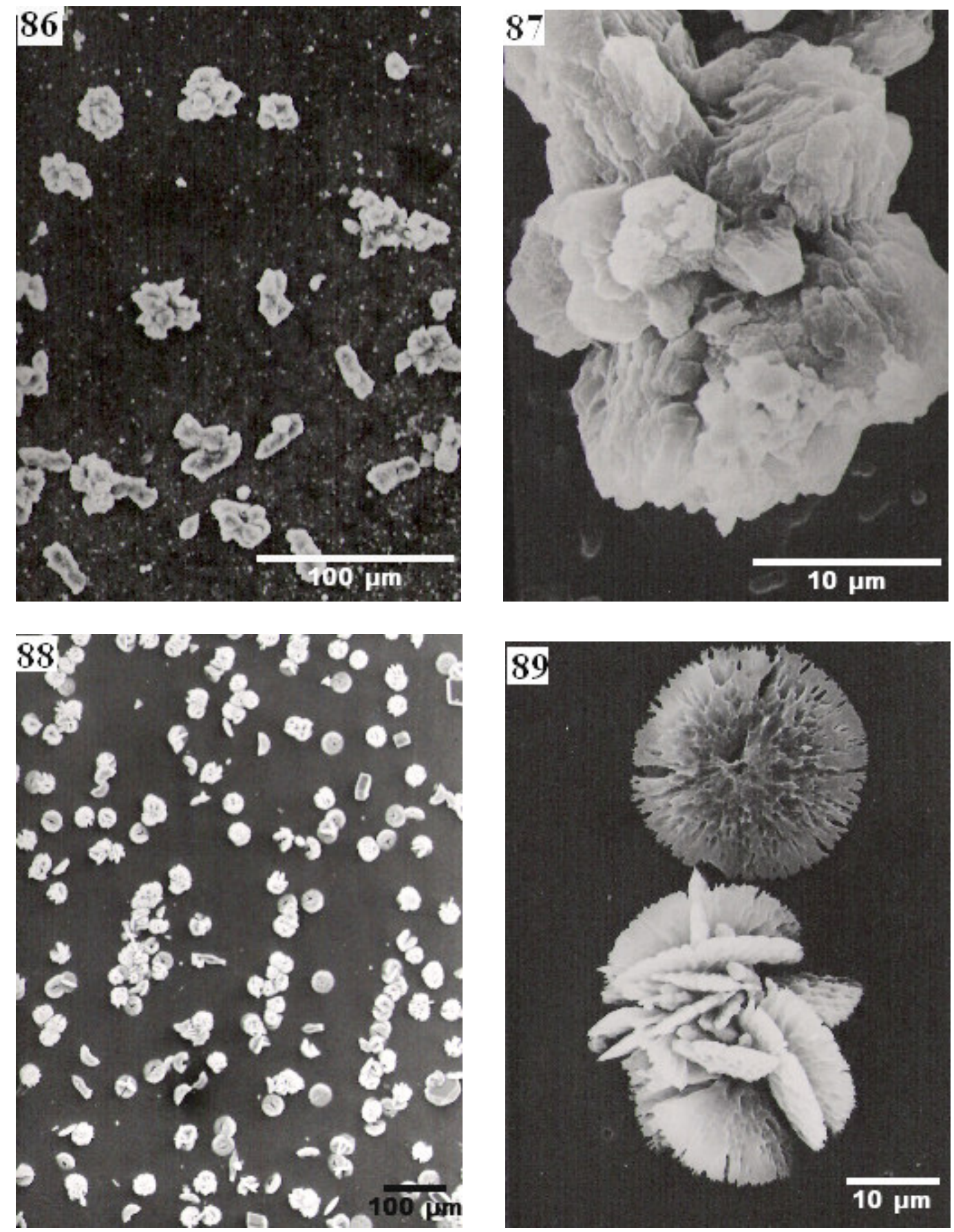

Figuras 86 - Cristais formados na solução controle B, em presença de $1 \mathrm{mg} \cdot \mathrm{mL}^{-1}$ de quitina Figura 87 - Detalhe de agregado cristalino exibido na Figura 86.

Figuras 88 - Cristais formados na solução B, em presença de $1 \mathrm{mg} \cdot \mathrm{mL}^{-1}$ de glicina. Figura 89 - Agregados de placas porosas, detalhes da Figura 88. 

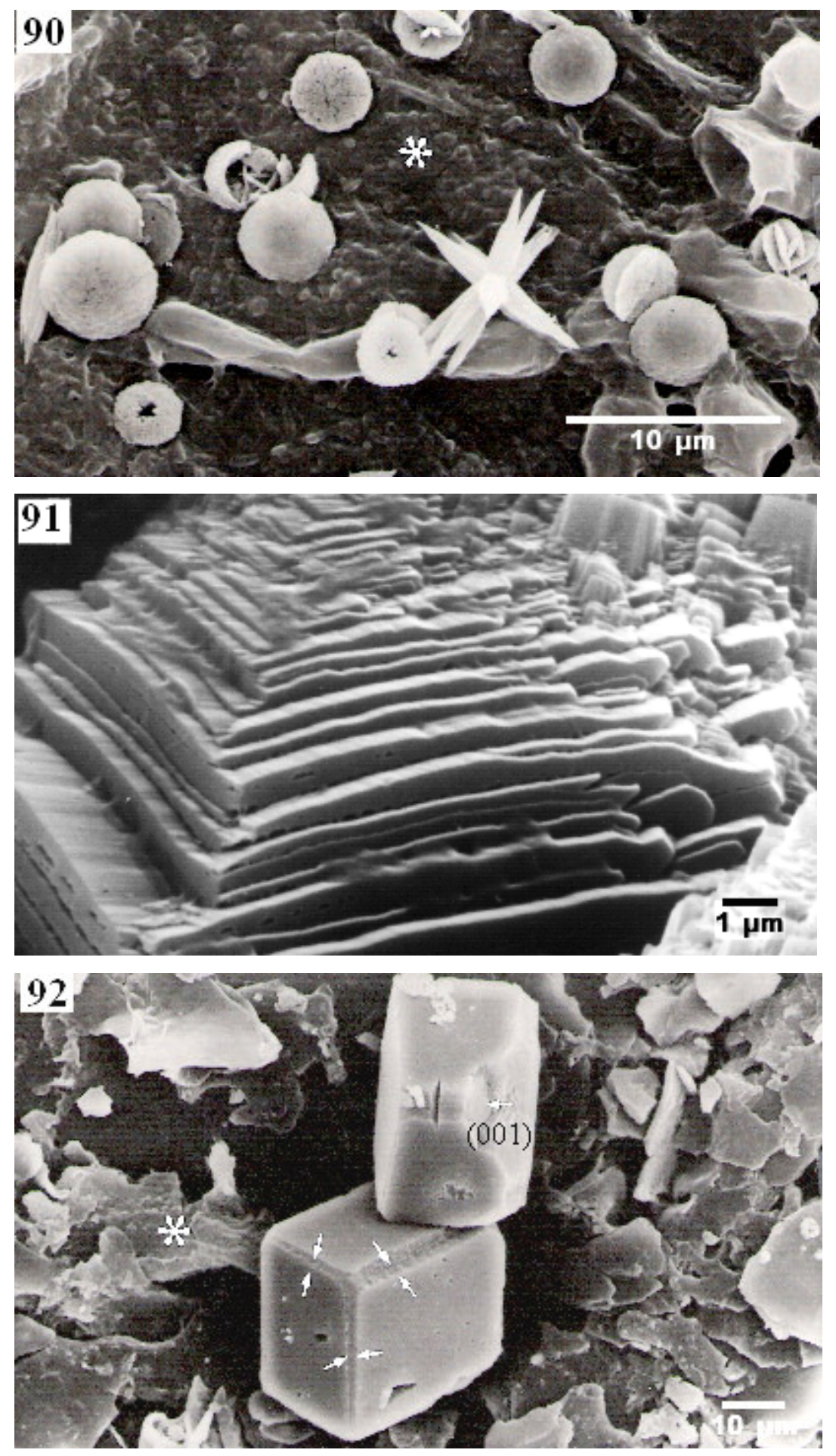

Figuras 90 - Cristais esféricos formados em presença de matéria orgânica insolúvel (*). Figura 91 - Degraus formados por lamelas.

Figura 92 - Calcita romboédrica com alterações em suas faces. 

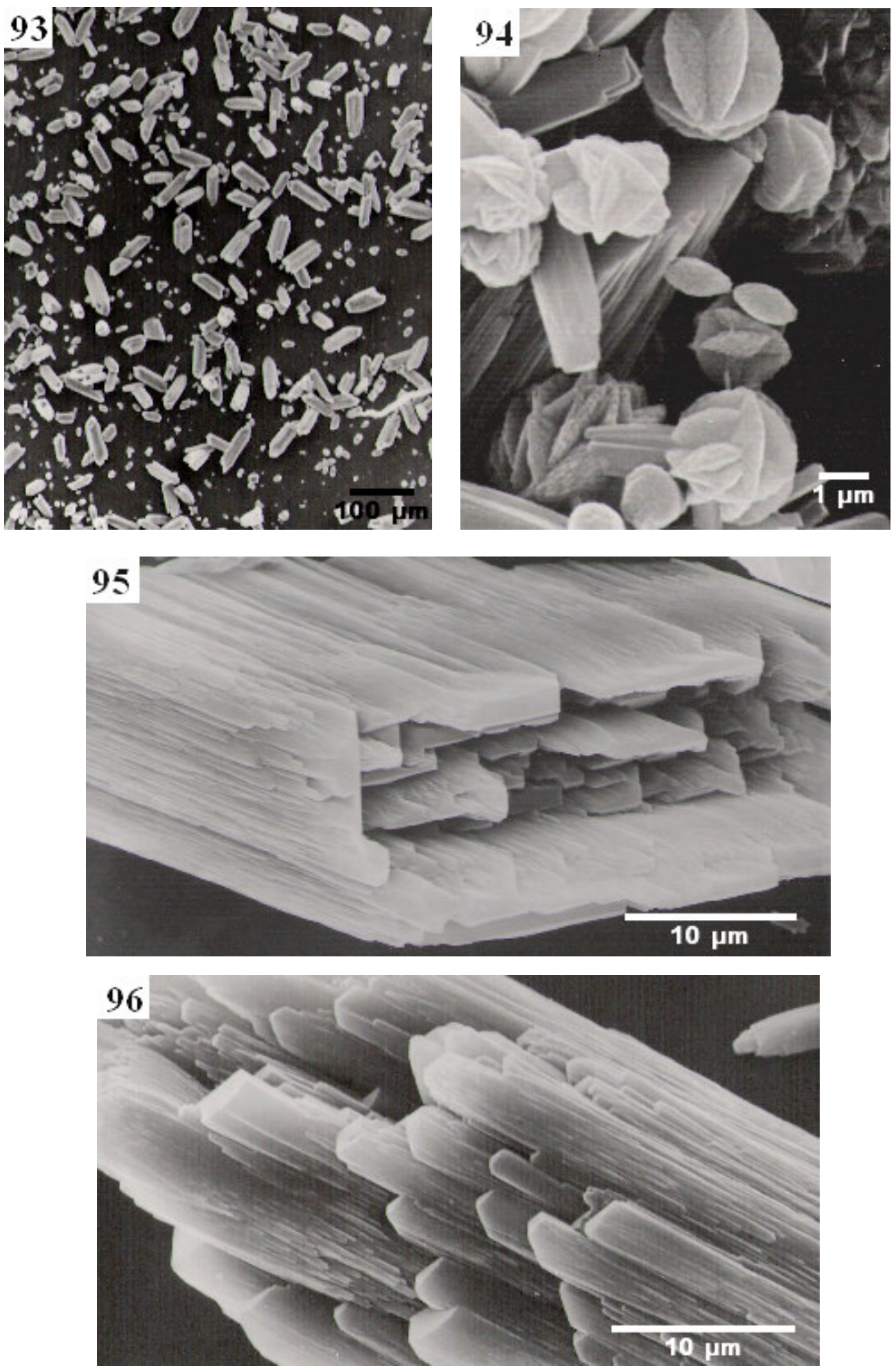

Figura 93 - Dispersão de cristais com formas diversas.

Figura 94 - Cristais com formatos de placas e rosetas.

Figura 95 - Empilhamento de placas, semelhantes a "caixas". Figura 96 - Feixe de prismas. 


\section{Microscopia de luz (ML)}

Cristais de $\mathrm{CaCO}_{3}$ crescidos na solução com magnésio, apresentaram 30-55 $\mu \mathrm{m}$ de comprimento (Figura 97).

Em presença de ácido aspártico (Figura 98) ou de ácido glutâmico (Figura 99), houve a formação de cristais com comprimentos de $47-57 \mu \mathrm{m}$ e $45-55 \mu \mathrm{m}$, respectivamente.

A adição de serina (Figura 100) ou de glicina (Figura 101) à solução com magnésio produziu cristais com comprimentos de $40-45 \mu \mathrm{m}$ e $40-50 \mu \mathrm{m}$, respectivamente.

O estudo das dimensões dos cristais obtidos em presença de quitina não foi realizado, visto que foram observados apenas aglomerados cristalinos.

A glicina, adionada à solução sem magnésio à razão de $0,1 \mathrm{mg} \cdot \mathrm{mL}^{-1}$, produziu cristais

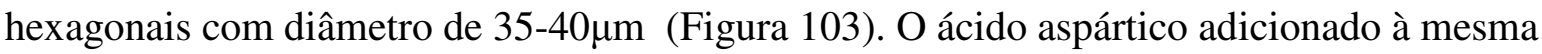

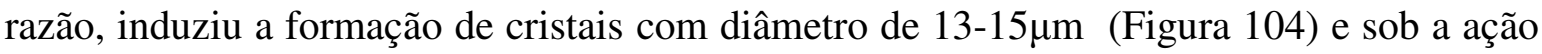

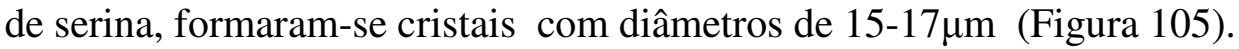

A solução de controle, sem magnésio, produziu cristais com variações morfológicas, impossibilitando o estudo de suas dimensões (Figura 102). 

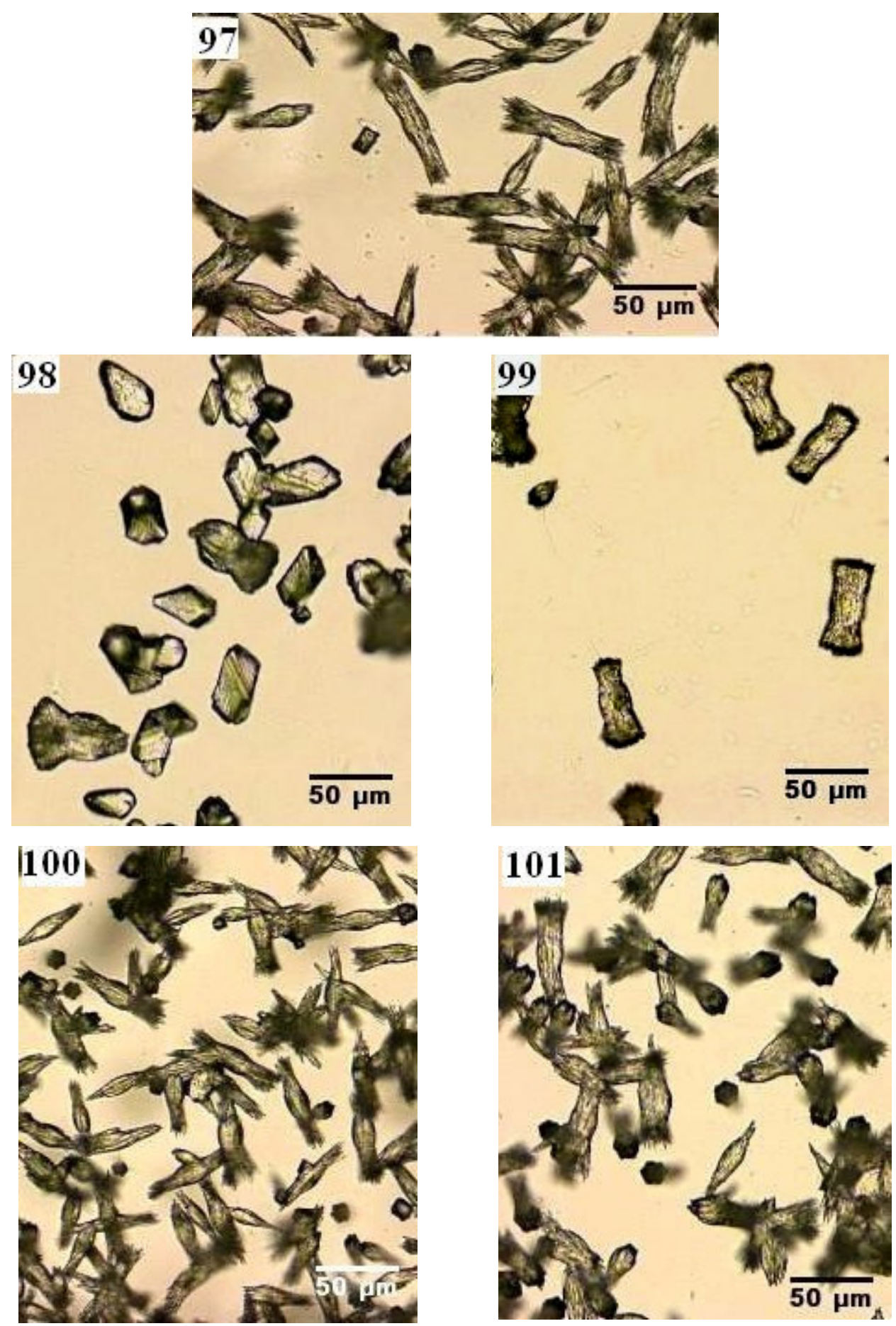

Figura 97 - Cristais obtidos com a adição de magnésio na solução de $\mathrm{CaCO}_{3}$. Figura 98 - Cristais formados a partir da adição de $0,1 \mathrm{mg} \cdot \mathrm{mL}^{-1}$ de Asp na solução A. Figura 99 - Cristais formados a partir da adição de $0,1 \mathrm{mg} \cdot \mathrm{mL}^{-1}$ de Glu na solução A. Figura 100 - Cristais formados a partir da adição de $0,1 \mathrm{mg} \cdot \mathrm{mL}^{-1}$ de Ser na solução A. Figura 101 - Cristais formados a partir da adição de $0,1 \mathrm{mg} \cdot \mathrm{mL}^{-1}$ de Gly na solução A. 

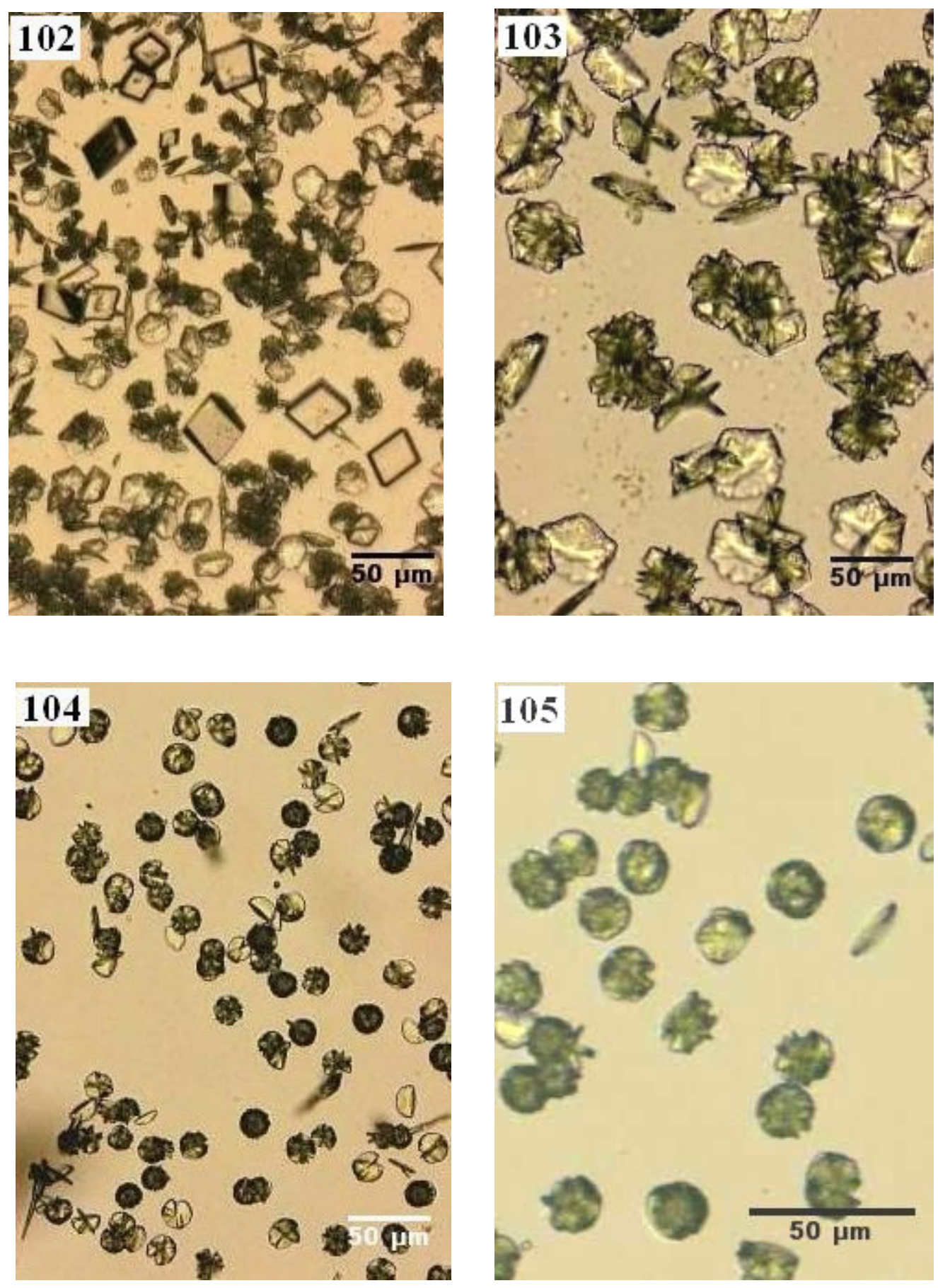

Figura 102 - Cristais formado sem adição de magnésio à solução de $\mathrm{CaCO}_{3}$. Figura 103 - Cristais formados em presença de $0,1 \mathrm{mg} \cdot \mathrm{mL}^{-1}$ de Gly na solução B. Figura 104 - Cristais formados em presença de $0,1 \mathrm{mg} \mathrm{mL}^{-1}$ de Asp na solução B. Figura 105 - Cristais formados em presença de $0,1 \mathrm{mg}^{-\mathrm{mL}^{-1}}$ de Ser na solução B. 


\section{Análises quantitativas e qualitativas das fases cristalinas.}

\section{Difração de elétrons (DEAS)}

A difração de elétrons de área selecionada, foi realizada apenas para os cristais crescidos em presença de $1 \mathrm{~g}$ de aditivo (apenas ácido aspártico e ácido glutâmico) para cada litro de solução com magnésio. Para os demais casos, usou-se a difração de raios-X para a identificação dos polimorfismos obtidos.

A difração eletrônica permitiu identificar a estrutura dos cristais formados em presença de ácido glutâmico, como sendo calcita. Para a indexação dos diagramas, foram utilizados os parâmetros de rede cristalina hexagonal, com a $=\mathrm{b}=4,99 \AA, \mathrm{c}=17,06 \AA, \alpha$ $=\beta=90^{\circ}$ e $\gamma=120^{\circ}$. A Tabela 8 mostra os resultados experimentais e teóricos referentes à indexação da calcita. Na Figura 106 são apresentados o diagrama de difração e a morfologia da área selecionada.

Para a indexação dos diagramas dos cristais crescidos sob ação de ácido aspártico, foram utilizados para a calcita, os parâmetros de rede cristalina hexagonal, $\operatorname{com} \mathrm{a}=\mathrm{b}=$ $4,99 \AA$ e $\mathrm{c}=17,06 \AA, \alpha=\beta=90^{\circ}$ e $\gamma=120^{\circ}$. Para a vaterita, os parâmetros utilizados

foram $\mathrm{a}=\mathrm{b}=7,15 \AA \mathrm{e} \mathrm{c}=16,92 \AA$ com $\alpha=\beta=90^{\circ}$ e $\gamma=120^{\circ}$, também pertencentes ao sistema hexagonal.

As Tabelas 9 e 10 contêm os dados teóricos e experimentais correspondentes às indexações da calcita e da vaterita, respectivamente. As Figuras 107 e 108 referem-se aos diagramas de difração e à morfologia das áreas selecionadas, referentes à calcita e à vaterita, respectivamente. 
Tabela 8 - Dados de indexação da calcita .

\begin{tabular}{lllll}
\hline $\begin{array}{c}\mathbf{d}_{\text {experimental }}(\mathbf{m m}) \\
(\mathbf{m m})\end{array}$ & $\begin{array}{l}\mathbf{d}_{\text {teórico }} \\
(\mathbf{m m k}\end{array}$ & ângulo experimental & ângulo teórico \\
\hline 3,00 & 3,03 & 014 & $0,00^{\circ}$ & $0,00^{\circ}$ \\
1,61 & 1,62 & $\overline{2} 27$ & $43,10^{\circ}$ & $42,70^{\circ}$ \\
2,25 & 2,28 & $\overline{2} 13$ & $74,00^{\circ}$ & $73,39^{\circ}$ \\
1,18 & 1,18 & $\overline{4} 12$ & $95,50^{\circ}$ & $95,39^{\circ}$ \\
2,12 & 2,14 & $\overline{2} 0 \overline{1}$ & $116,00^{\circ}$ & $115,97^{\circ}$ \\
1,46 & 1,47 & $\overline{2} \overline{1} \overline{5}$ & $142,00^{\circ}$ & $141,84^{\circ}$ \\
\hline
\end{tabular}
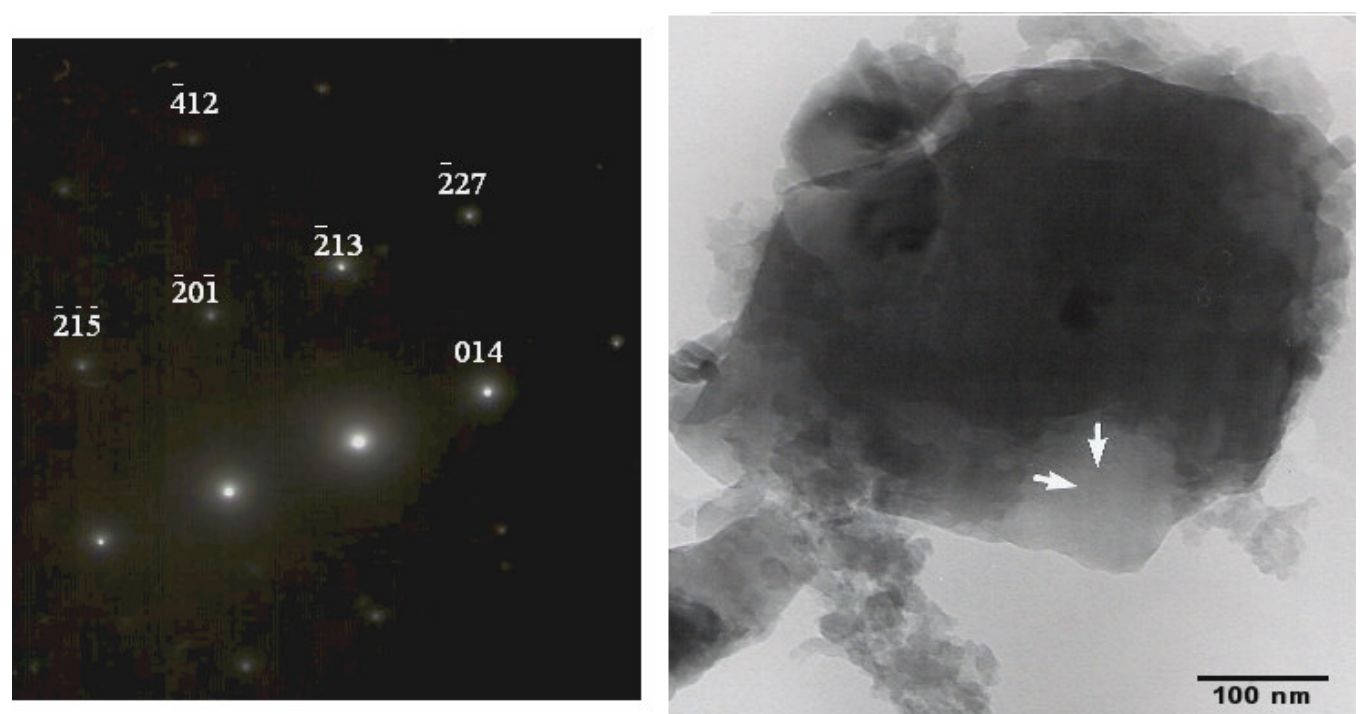

Fig. 106 - Diagrama de difração da calcita e morfologia do cristal correspondente selecionado para análise. 
Tabela 9 - Dados de indexação da calcita.

\begin{tabular}{lllll}
\hline $\begin{array}{c}\mathbf{d}_{\text {experimental }} \\
(\mathbf{m m})\end{array}$ & $\begin{array}{l}\mathbf{d}_{\text {teórico }} \\
(\mathbf{m m})\end{array}$ & $\mathbf{h k l}$ & ângulo experimental & ângulo teórico \\
\hline 4,54 & 4,32 & 100 & $0,00^{\circ}$ & $0,00^{\circ}$ \\
2,59 & 2,49 & $2 \overline{1} 0$ & $30,00^{\circ}$ & $30,00^{\circ}$ \\
4,52 & 4,32 & $1 \overline{1} 0$ & $60,00^{\circ}$ & $60,00^{\circ}$ \\
1,71 & 1,63 & $2 \overline{3} 0$ & $79,00^{\circ}$ & $79,11^{\circ}$ \\
2,63 & 2,50 & $1 \overline{2} 0$ & $90,00^{\circ}$ & $90,00^{\circ}$ \\
\hline
\end{tabular}
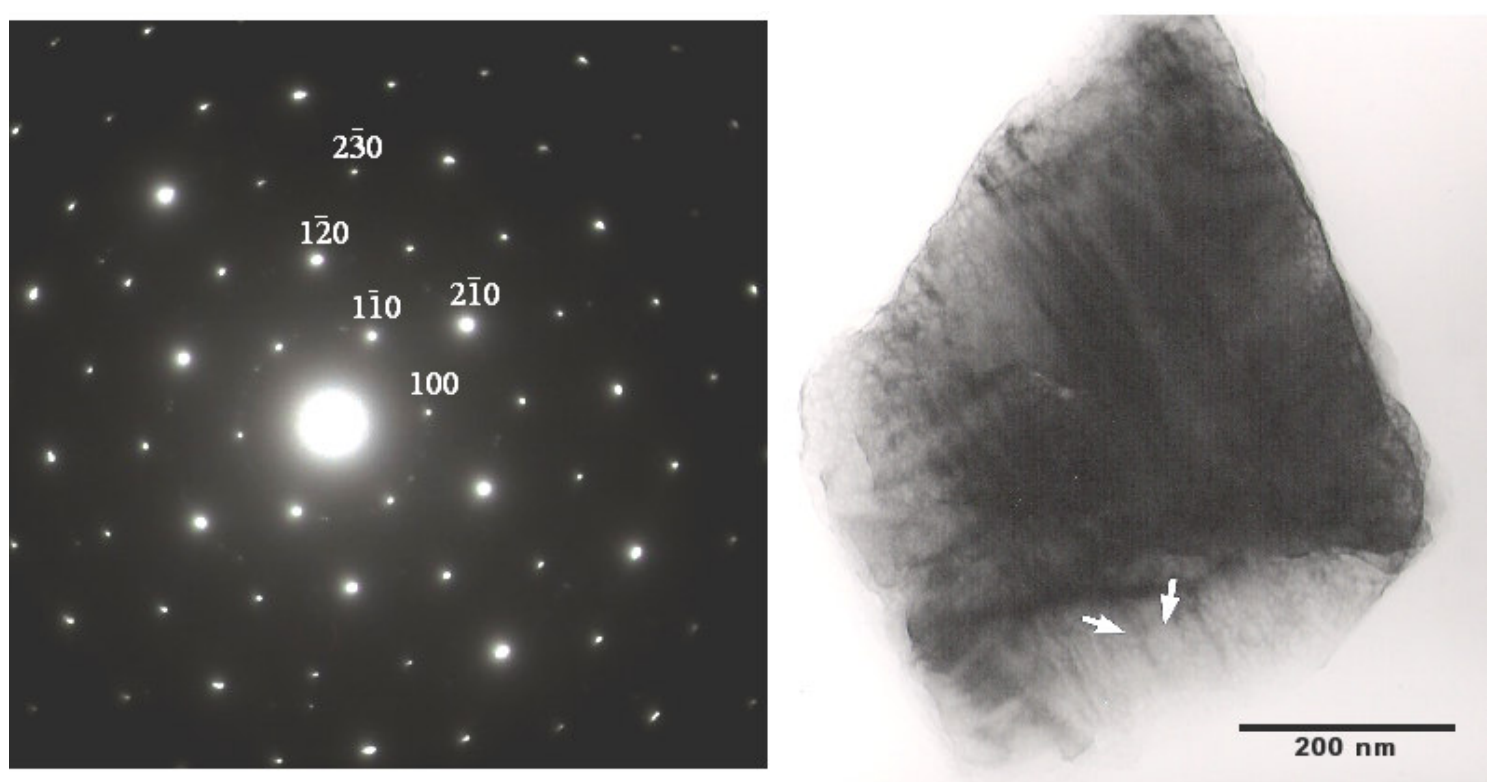

Fig. 107 - Diagrama de difração da calcita e imagem da área correspondente. 
Tabela 10 - Dados de indexação da vaterita.

\begin{tabular}{lllll}
\hline $\begin{array}{l}\mathbf{d}_{\text {experimental }} \\
(\mathbf{m m})\end{array}$ & $\begin{array}{l}\mathbf{d}_{\text {térico }} \\
(\mathbf{m m})\end{array}$ & $\mathbf{h k l}$ & ângulo experimental & ângulo teórico \\
\hline 4,98 & 4,99 & 102 & $0,00^{\circ}$ & $0,00^{\circ}$ \\
2,20 & 2,21 & $\overline{1} 26$ & $61,00^{\circ}$ & $62,38^{\circ}$ \\
2,49 & 2,49 & $\overline{2} 24$ & $88,00^{\circ}$ & $88,68^{\circ}$ \\
2,28 & 2,25 & $\overline{3} 22$ & $115,00^{\circ}$ & $115,50^{\circ}$ \\
1,78 & 1,78 & $\overline{4} 20$ & $134,00^{\circ}$ & $134,34^{\circ}$ \\
1,11 & 1,13 & $\overline{6} 2 \overline{4}$ & $153,00^{\circ}$ & $153,17^{\circ}$ \\
\hline
\end{tabular}
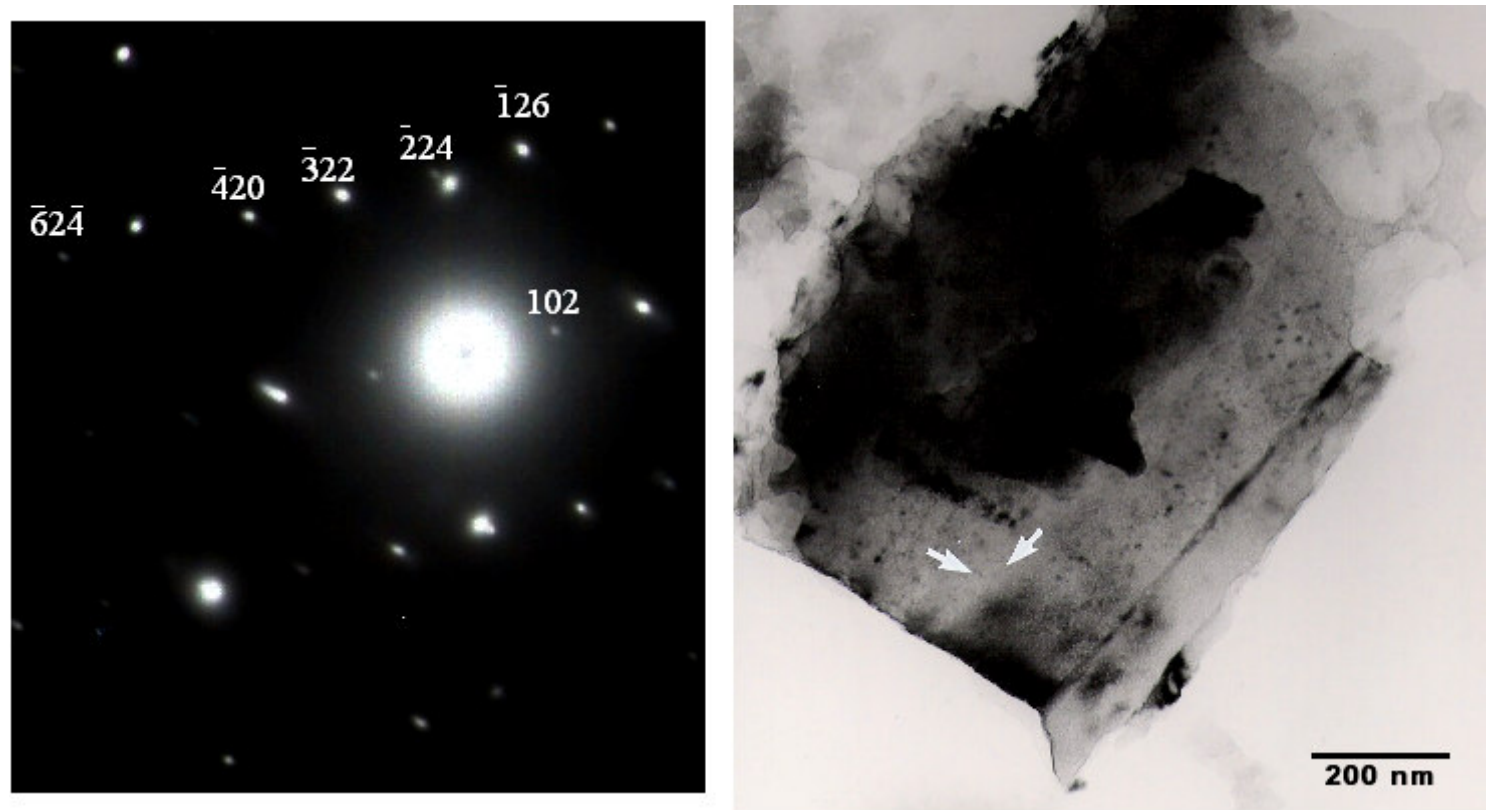

Fig. 108 - Diagrama de difração da vaterita e morfologia da área selecionada para análise. 


\section{Difração de raios-X (DRX)}

Para o ajuste da fase cristalina aplicando o método de Rietveld, foram utilizados os seguintes parâmetros: aragonita pertencente ao sistema ortorrômbico, espaço de grupo Pmcn e $\alpha=\beta=\gamma=90^{\circ}$. Para a calcita, foi adotado o sistema romboédrico, espaço de grupo R-3c e $\quad \alpha=\beta=90^{\circ}$ e $\gamma=120^{\circ}$. Para a vaterita, os parâmetros foram do sistema hexagonal, com espaço de grupo P 63/mmc e $\alpha=\beta=90^{\circ}$ e $\gamma=120^{\circ}$.

Nos gráficos apresentados (figuras 109 até 124), a cor vermelha corresponde aos dados experimentais, a cor verde aos dados teóricos e a linha inferior lilás, é associada ao resultado do refinamento.

A análise quantitativa dos cristais crescidos na solução de controle A, resultou em 99,34 \% de cristais de aragonita, com parâmetros de cela $a=4,96 \AA, b=7,97 \AA$ e $c=5,75 \AA$; e $0,66 \%$ de calcita, com $\mathrm{a}=4,99 \AA, \mathrm{b}=7,97 \AA$ e $\mathrm{c}=17,06 \AA$. O fator de qualidade do refinamento ( S) foi de 1,24 (Figura 109).

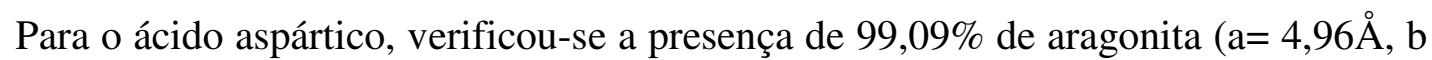
$=7,97 \AA$ e $\mathrm{c}=5,75 \AA)$; e $0,91 \%$ de calcita $(\mathrm{a}=\mathrm{b}=4,994 \AA$ e $\mathrm{c}=17,06 \AA)$; o fator $\mathrm{S}$ foi de 1,30 (Figura 110).

A adição de ácido glutâmico à solução, produziu 96,22\% de aragonita (a = 4,96̊, b $=7,97 \AA$ e $\mathrm{c}=5,75 \AA)$; e $3,78 \%$ de calcita $(\mathrm{a}=\mathrm{b}=4,98 \AA$ e $\mathrm{c}=16,99 \AA) ;$ com $\mathrm{S}=1,91$ (Figura 111).

Houve a cristalização de $98,17 \%$ de aragonita $(a=4,96 \AA, b=7,97 \AA$ e c $=5,75 \AA)$; e $1,83 \%$ de calcita $(\mathrm{a}=\mathrm{b}=4,98 \AA$ e $\mathrm{c}=16,98 \AA$ ), para a adição de glicina à solução de controle A. O fator S foi de 1,34 (Figura 112). 
Houve a cristalização basicamente de aragonita $(\mathrm{a}=4,96 \AA, \mathrm{b}=7,97 \AA$ e c $=5,75 \AA)$ para a adição de serina à solução de controle; $\mathrm{S}=1,32$ (Figura 113).

A quitina mostrou ser o aditivo que apresenta a maior capacidade de modificações morfológicas e polimórficas. Os resultados do refinamento indicaram a presença apenas de calcita $(\mathrm{a}=\mathrm{b}=4,97 \AA$; e c $=17,01 \AA)$; $\mathrm{S}=1,33$ (Figura 114). 


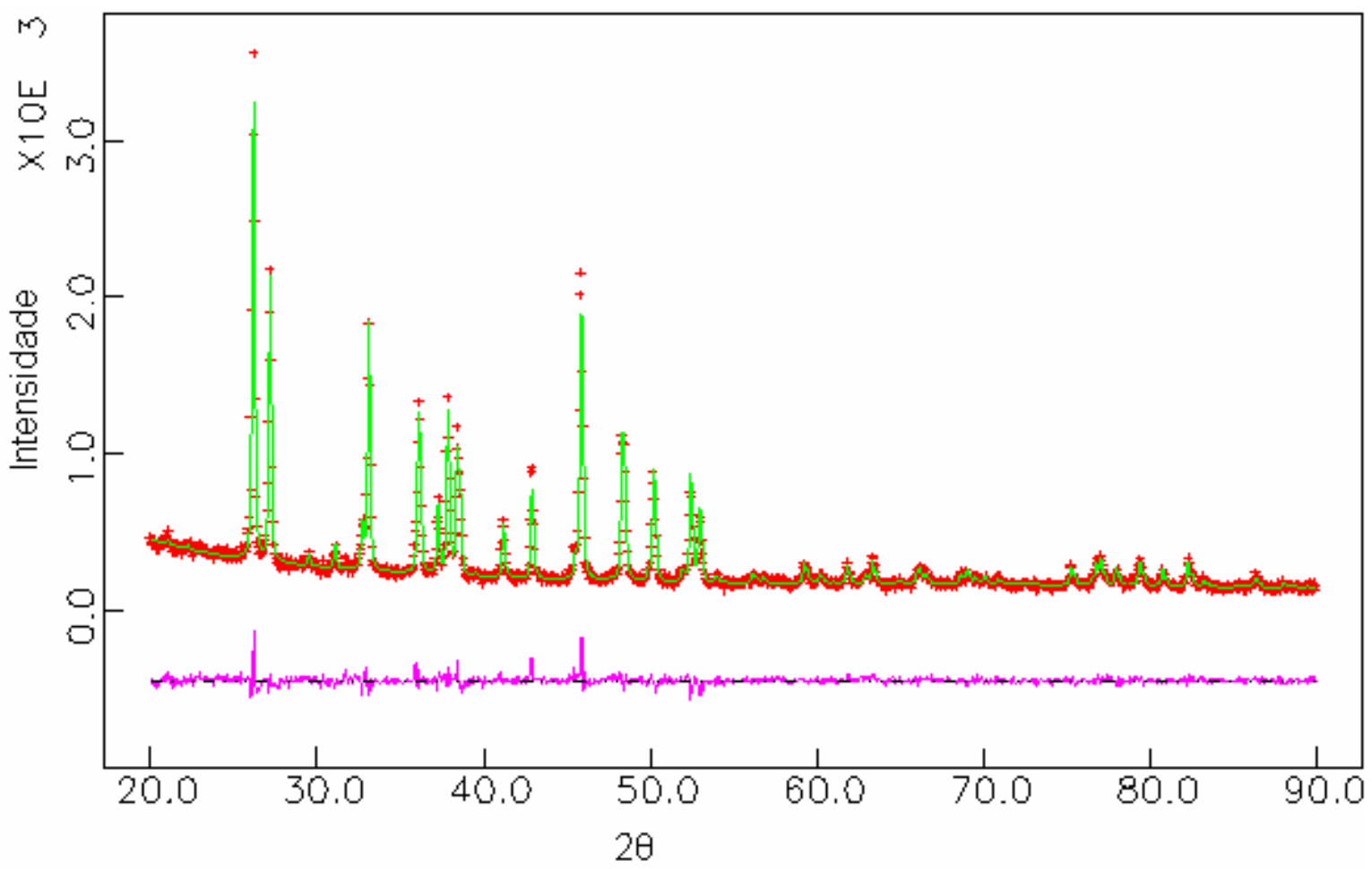

Figura 109 - Gráfico de Rietveld para os cristais de $\mathrm{CaCO}_{3}$ (solução de controle A).

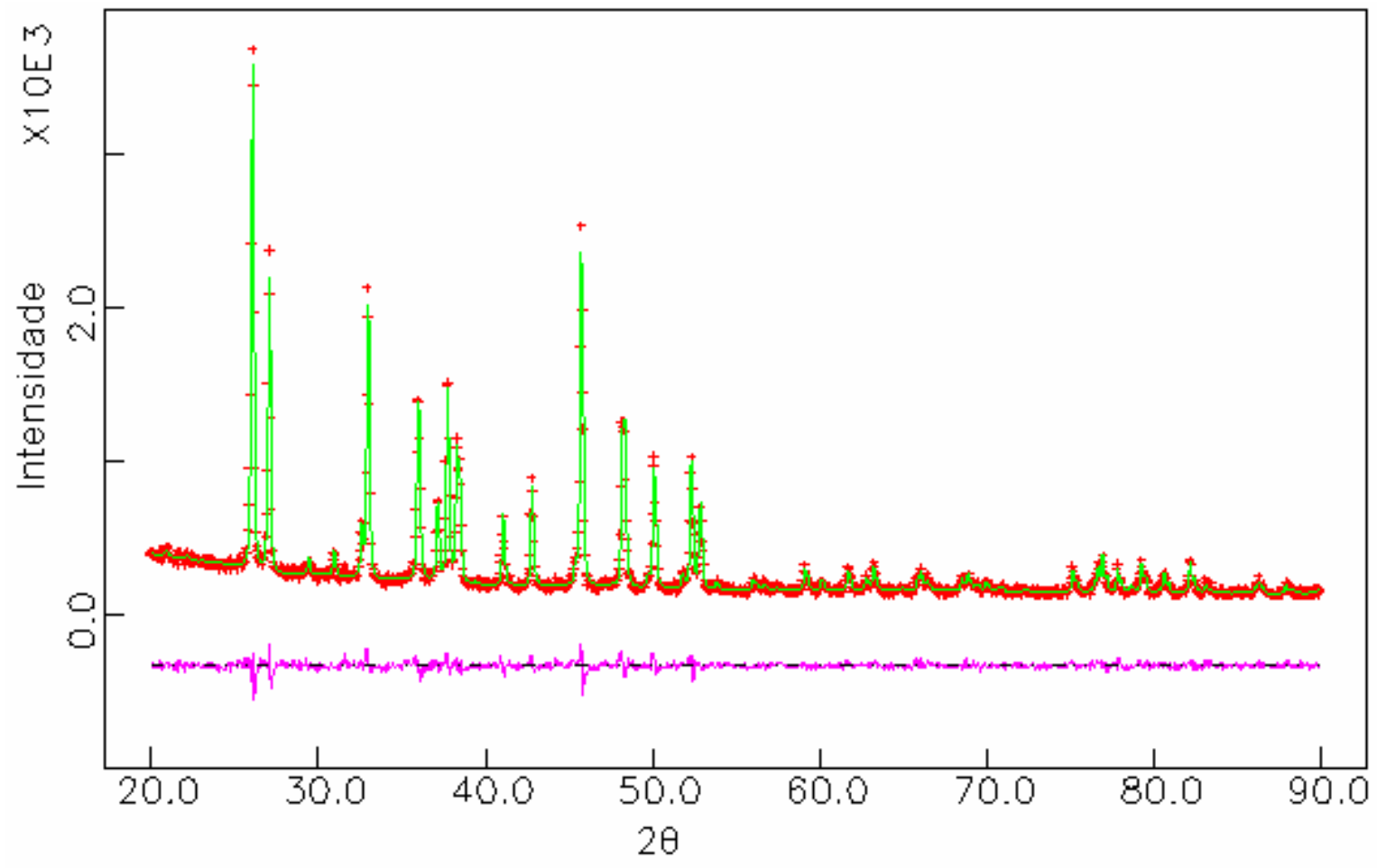

Figura 110- Gráfico de Rietveld para os cristais formados em presença de ácido aspártico. 


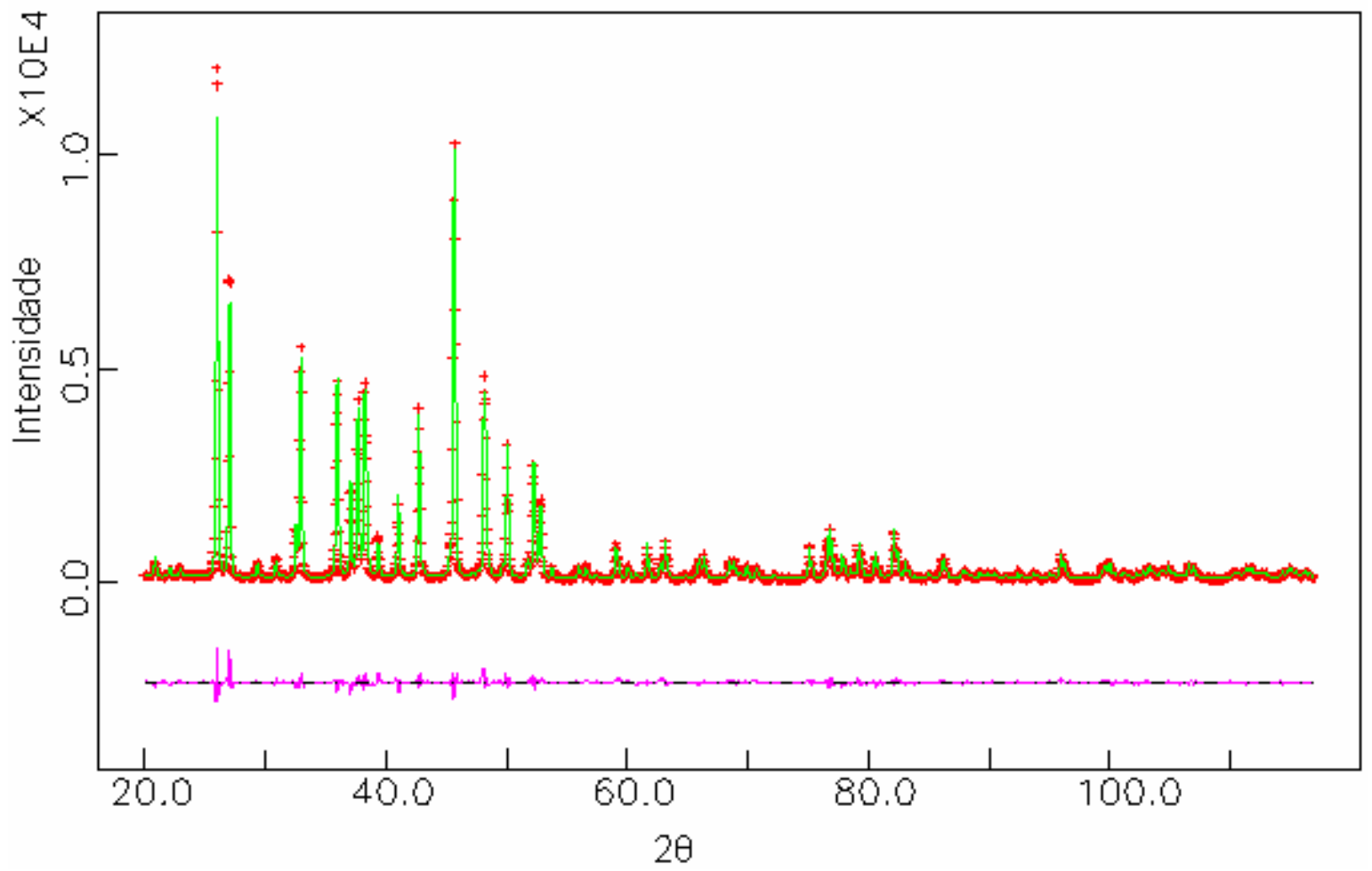

Figura 111- Gráfico de Rietveld para os cristais formados em presença de ácido glutâmico.

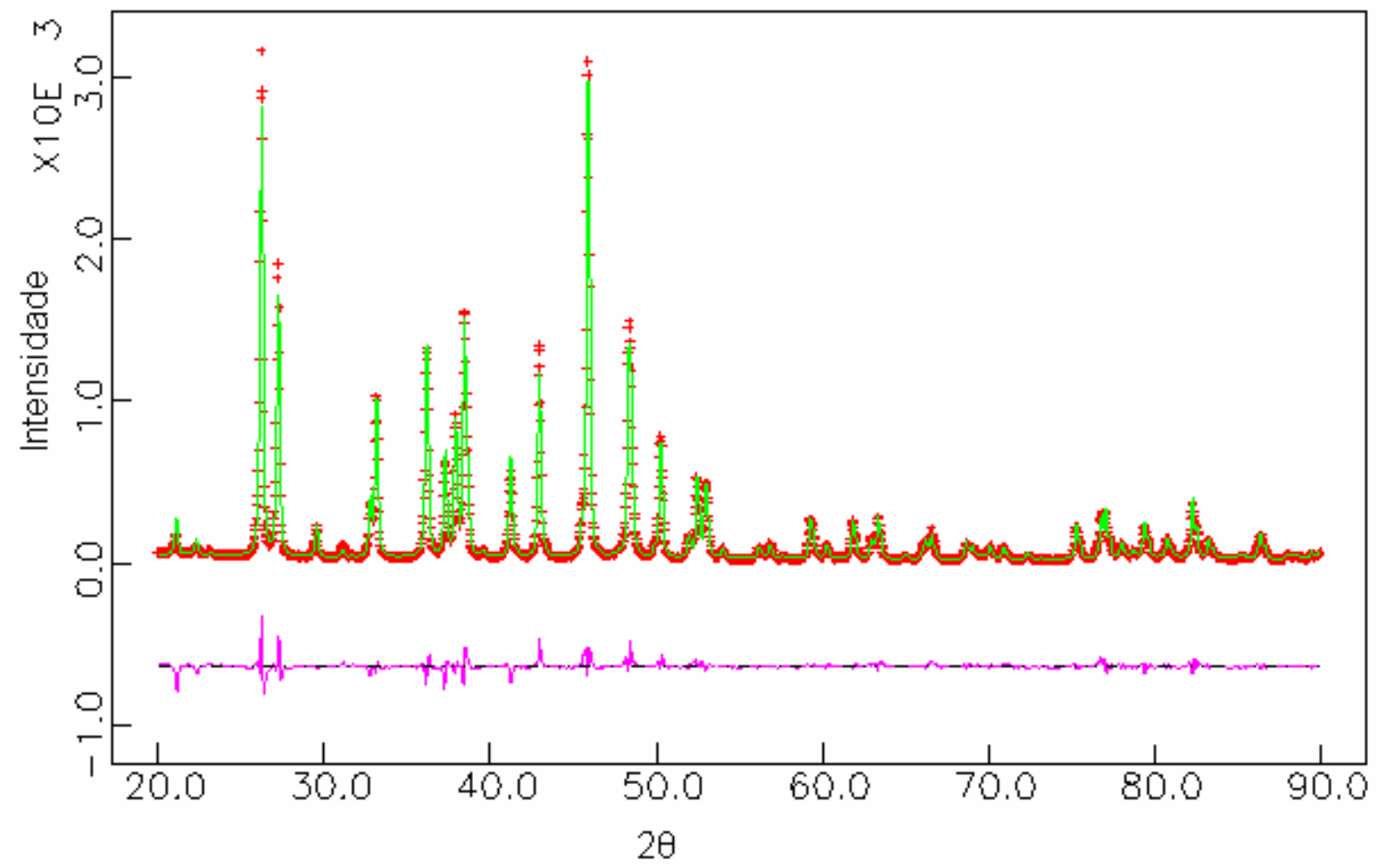

Figura 112 - Gráfico de Rietveld para os cristais formados em presença de glicina. 


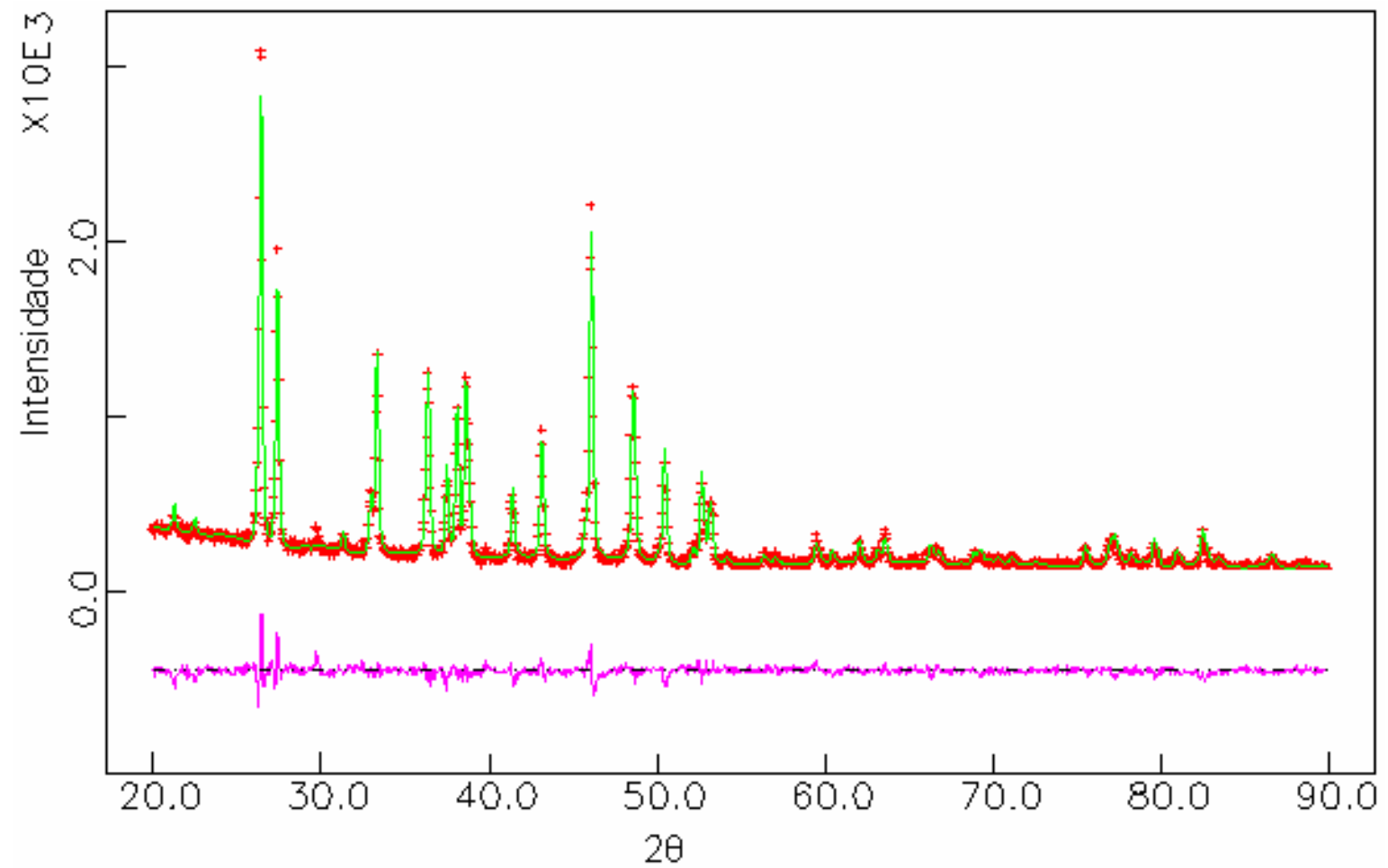

Figura 113- Gráfico de Rietveld para os cristais formados em presença de serina.

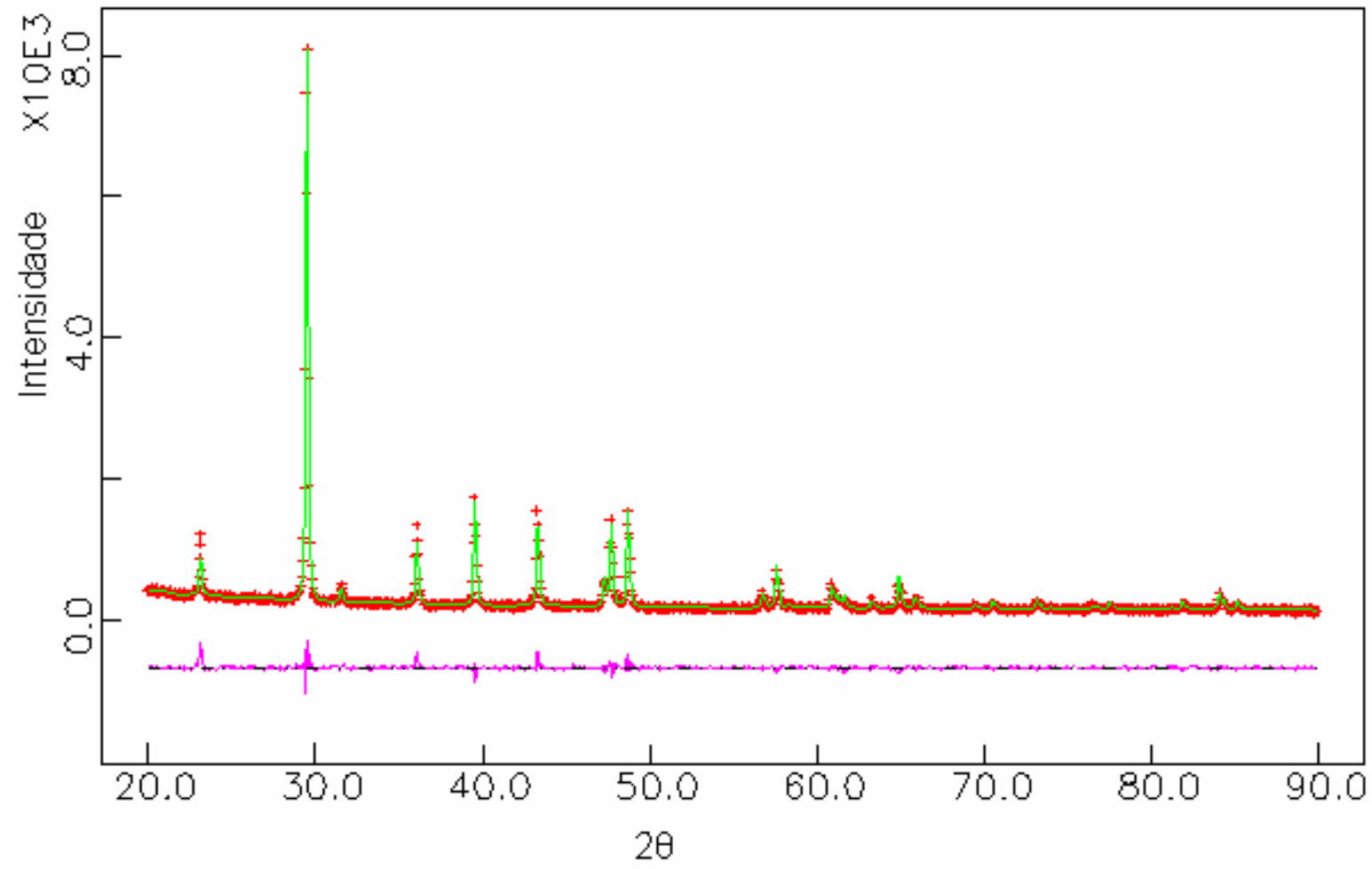

Figura 114- Gráfico de Rietveld para os cristais formados em presença de quitina. 
Para a solução de controle B, sem adição de magnésio, obteve-se a cristalização de $79,64 \%$ de calcita $(\mathrm{a}=\mathrm{b}=4,99 \AA)$ e $20,36 \%$ de vaterita $(\mathrm{a}=\mathrm{b}=4,12 \AA$ e $\mathrm{c}=8,45 \AA$ ) (Figura 115). $\mathrm{O}$ fator de qualidade foi $\mathrm{S}=1,23$.

Na Figura 116 observa-se o espectro para a cristalização de $\mathrm{CaCO}_{3}$ em presença de 0,1mg. $\mathrm{mL}^{-1}$ de ácido aspártico; 45,48\% dos cristais são calcita $(\mathrm{a}=\mathrm{b}=4,99 \AA \mathrm{e} \mathrm{c}=$ $17,06 \AA), 39,15 \%$ vaterita $(\mathrm{a}=\mathrm{b}=4,13 \AA$ e $\mathrm{c}=8,46 \AA)$ e apenas $15,37 \%$ aragonita $(\mathrm{a}=$ $4,96 \AA, b=7,96 \AA$ e c $=5,74 \AA) ; S=1,54$.

Para o ácido glutâmico, é apresentado apenas o espectro de raios-X para a concentração de $0,1 \mathrm{mg} \cdot \mathrm{mL}^{-1}$. Obteve-se 40,13\% de calcita $(\mathrm{a}=\mathrm{b}=4,99 \AA$ e $\mathrm{c}=17,05 \AA)$, $41,39 \%$ de vaterita $(\mathrm{a}=\mathrm{b}=4,12 \AA$ e $\mathrm{c}=8,45 \AA)$ e $18,48 \%$ de $\operatorname{aragonita}(\mathrm{a}=4,96 \AA, \mathrm{b}=$ $7,96 \AA$ e c $=5,74 \AA)($ Figura 117); S = 1,22.

As diferentes concentrações de quitina, produziram quantidades de calcita e vaterita similares. Será apresentado apenas, o espectro para a concentração de $1 \mathrm{mg} / \mathrm{mL}$. Houve a formação de 90,29\% de calcita e 9,71\% de vaterita, o fator de qualidade do ajuste foi 1,24 (Figura 118).

Os espectros de raios-X para as concentrações de $0,1 \mathrm{mg} \cdot \mathrm{mL}^{-1}$ e $1 \mathrm{mg} \cdot \mathrm{mL}^{-1}$ de glicina são mostrados nas figuras 119 e 120, respectivamente. Para a menor concentração, obtevese $\mathrm{S}=1,24$, com $71,77 \%$ de calcita $(\mathrm{a}=\mathrm{b}=4,99 \AA$ e $\mathrm{c}=17,06 \AA) ; 21,46 \%$ de vaterita $(\mathrm{a}=$ $\mathrm{b}=4,12 \AA$ e $\mathrm{c}=8,45 \AA) ; 6,77 \%$ de $\operatorname{aragonita}(\mathrm{a}=4,95 \AA, \mathrm{b}=7,97 \AA$ e $\mathrm{c}=5,74 \AA)$; o fator $\mathrm{S}=1,68$ para a maior concentração, com $87,30 \%$ de calcita $(\mathrm{a}=\mathrm{b}=4,99 \AA$ e $\mathrm{c}=17,07 \AA)$, $11,10 \%$ de vaterita $(\mathrm{a}=\mathrm{b}=7,14 \AA$ e $\mathrm{c}=16,94 \AA)$ e $1,60 \%$ de $\operatorname{aragonita}(\mathrm{a}=4,95 \AA, \mathrm{b}=$ $8,03 \AA$ e c $=5,81 \AA)$.

A adição $0,1 \mathrm{mg} \cdot \mathrm{mL}^{-1}$ de serina à solução cristalizou $63,71 \%$ de calcita $(\mathrm{a}=\mathrm{b}=$ $4,99 \AA$ e c $=17,06 \AA), 28,35 \%$ de vaterita $(\mathrm{a}=\mathrm{b}=4,12 \AA$ e $\mathrm{c}=8,46 \AA)$ e $7,94 \%$ de aragonita 


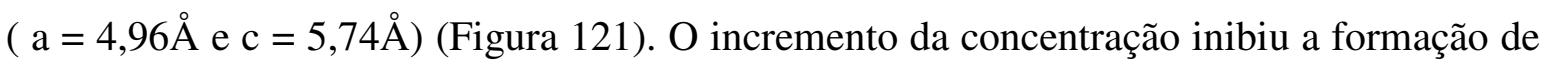
vaterita e aragonita, verificou-se apenas a presença de calcita $(\mathrm{a}=\mathrm{b}=4,99 \AA \mathrm{e} \mathrm{c}=17,07 \AA)$ (Figura 122).

O material orgânico insolúvel extraído da concha do molusco produziu 98,68\% de calcita $(\mathrm{a}=\mathrm{b}=4,99 \AA$ e $\mathrm{c}=17,07 \AA) ; 1,32 \%$ de aragonita; com fator $\mathrm{S}=1,63$ (Figura 123). A fração orgânica solúvel, produziu $55,35 \%$ de calcita ( $\mathrm{a}=\mathrm{b}=4,99 \AA$ e $\mathrm{c}=17,07 \AA$ ); $30,23 \%$ de aragonita $(a=4,96 \AA, b=7,97 \AA$ e $c=5,75 \AA) ; 14,42 \%$ de vaterita $(a=b=4,13 \AA$ e c $=8,47 \AA$ ). O fator S esteve em torno de 1,75 (Figura 124). 


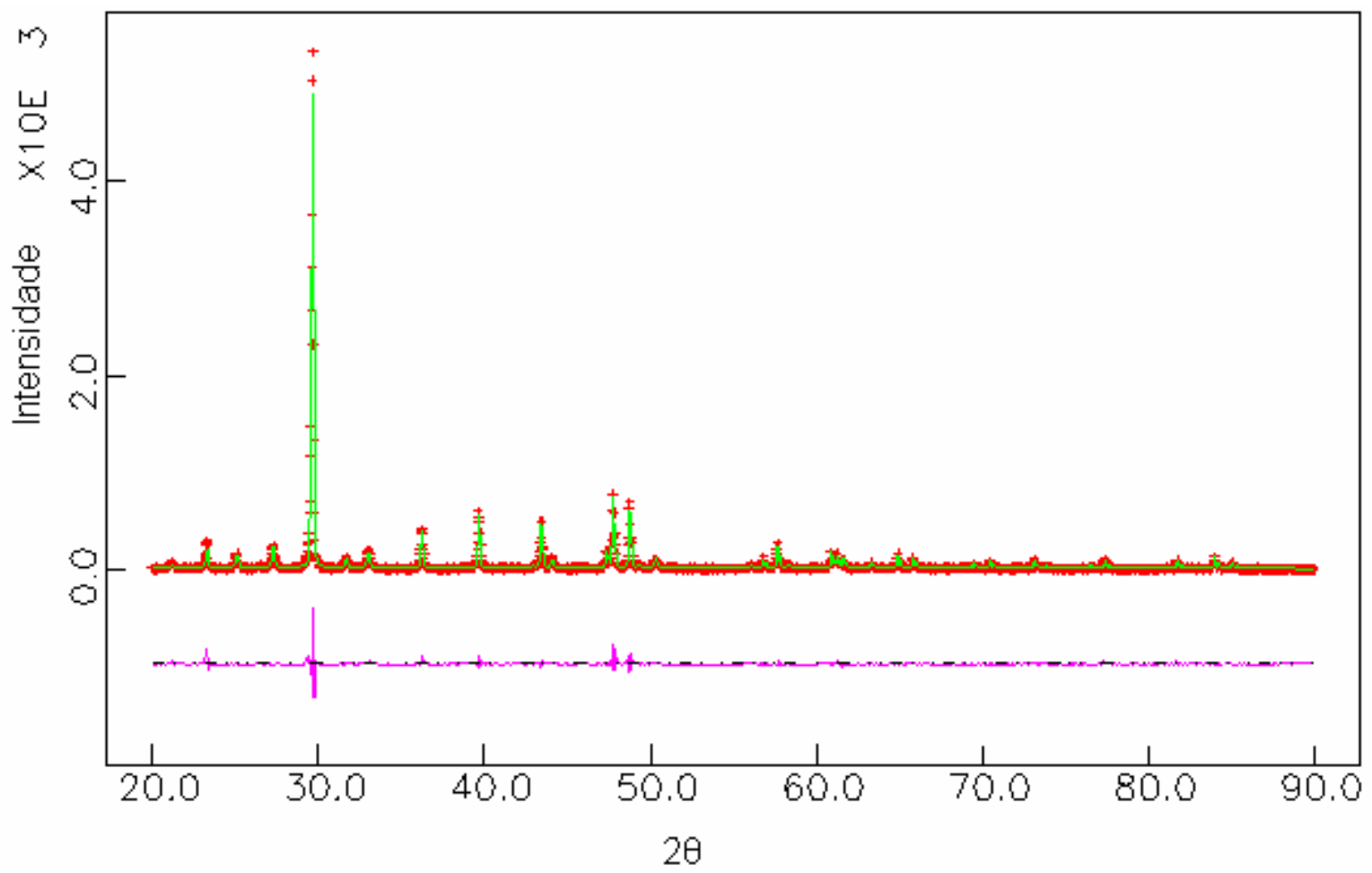

Figura 115 - Gráfico de Rietveld para os cristais de $\mathrm{CaCO}_{3}$ (Solução de controle B).

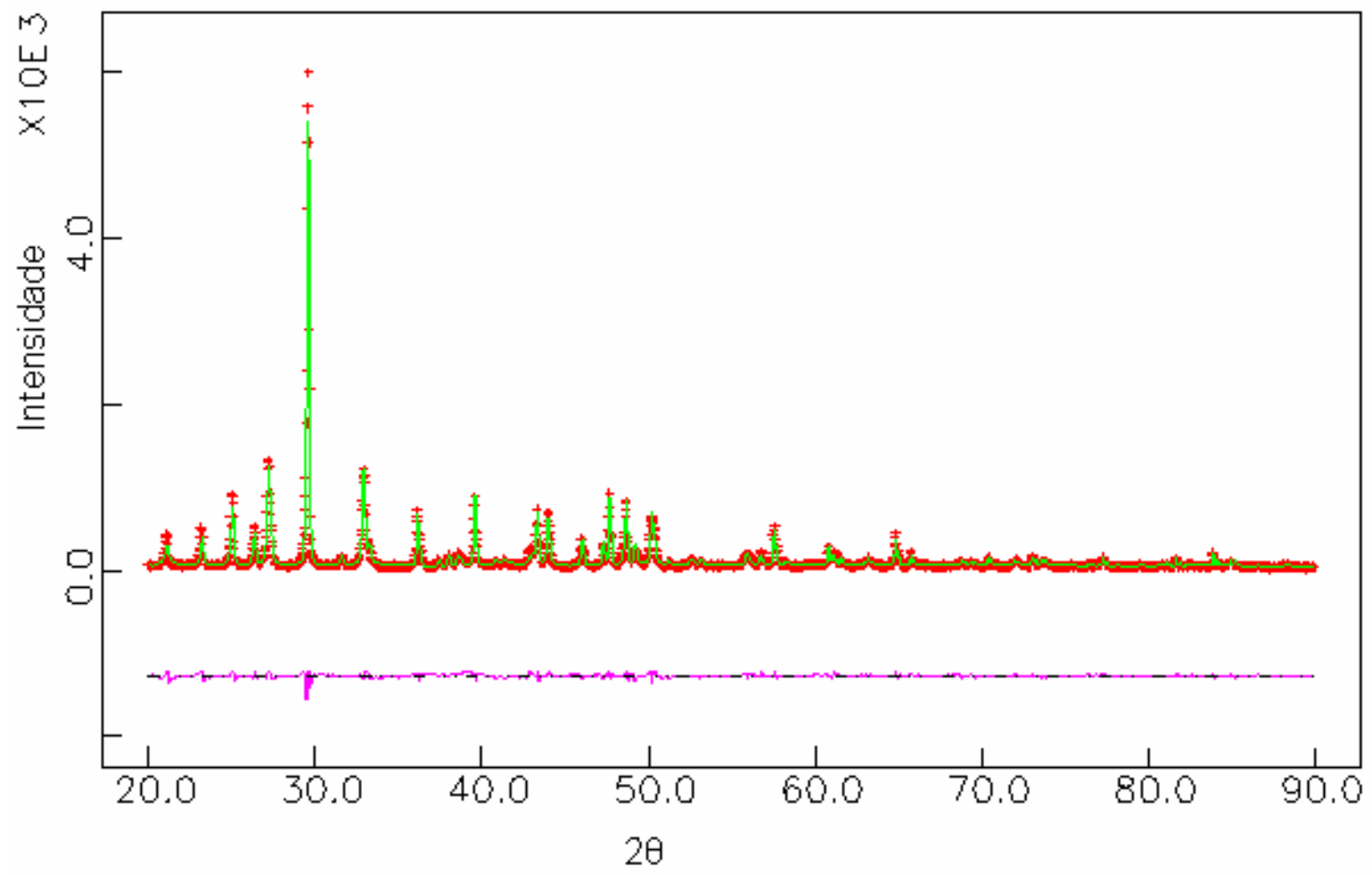

Figura 116 - Gráfico de Rietveld para os cristais formados em presença de Asp $\left(0,1 \mathrm{mg} \cdot \mathrm{mL}^{-1}\right)$. 


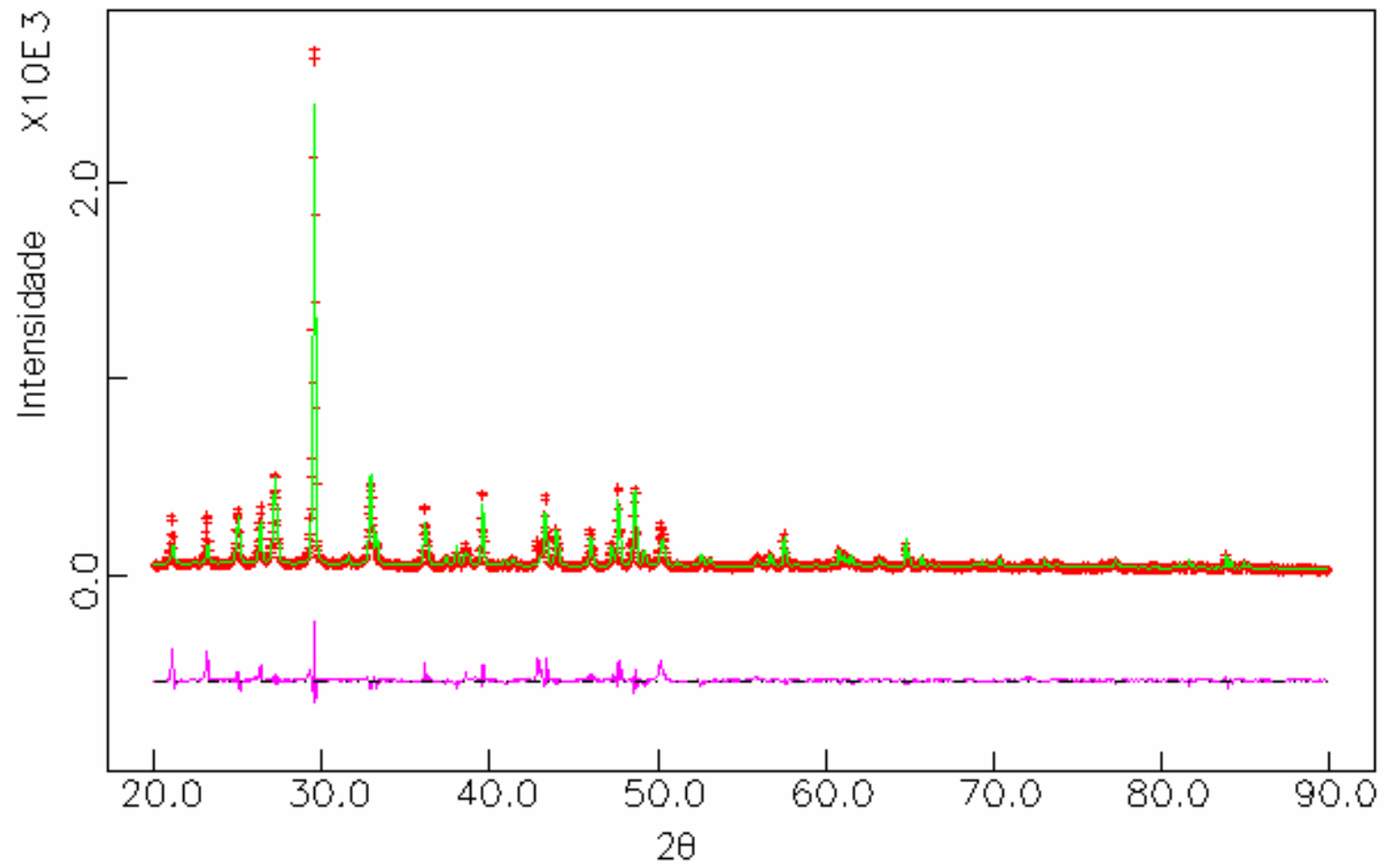

Figura 117 - Gráfico de Rietveld para os cristais formados em presença de Glu $\left(0,1 \mathrm{mg} \cdot \mathrm{mL}^{-1}\right)$.

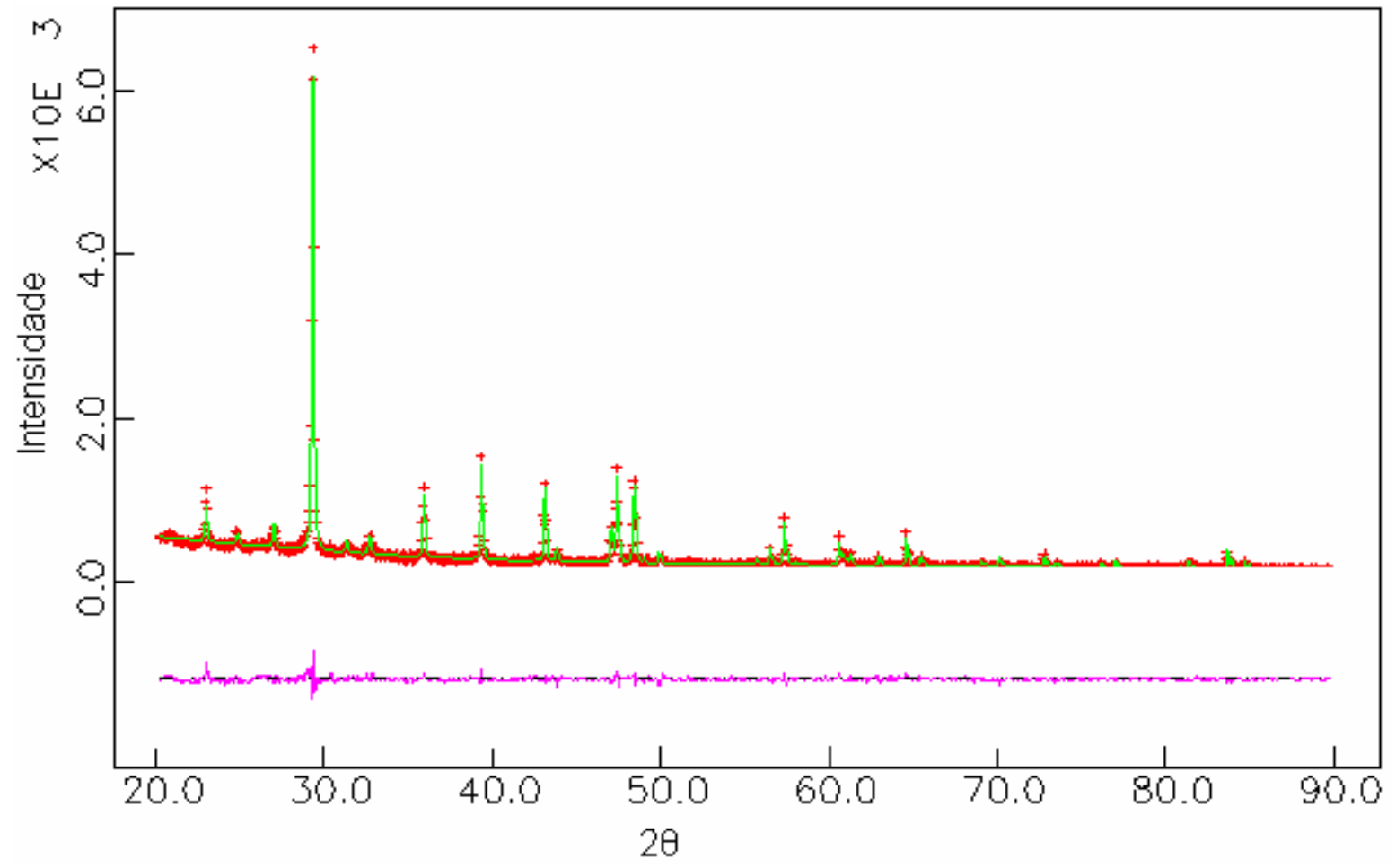

Figura 118 - Gráfico de Rietveld para os cristais formados em presença de quitina (1mg.mL $\left.{ }^{-1}\right)$. 


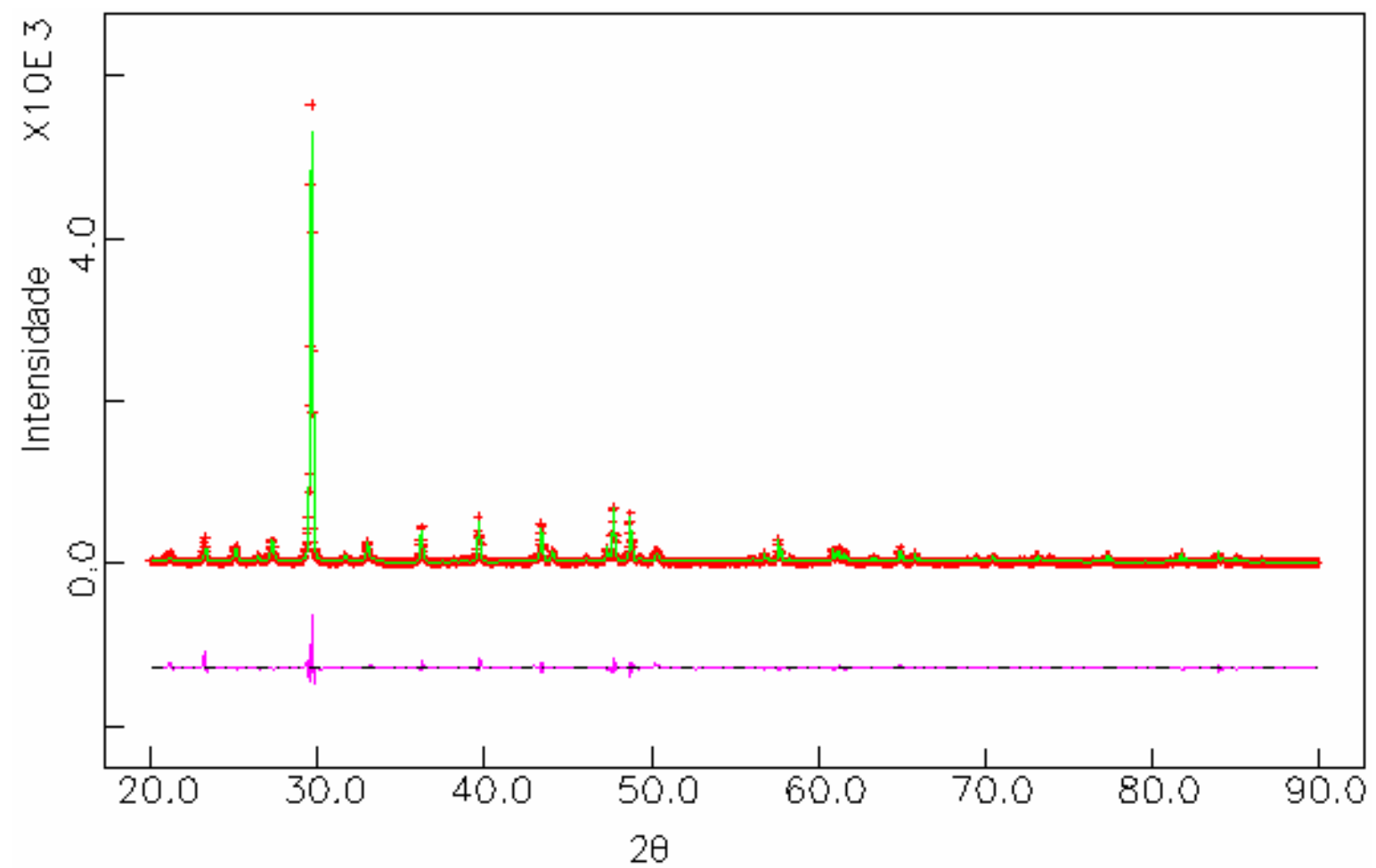

Figura 119 - Gráfico de Rietveld para os cristais formados em presença de Gly $\left(0,1 \mathrm{mg} \cdot \mathrm{mL}^{-1}\right)$.

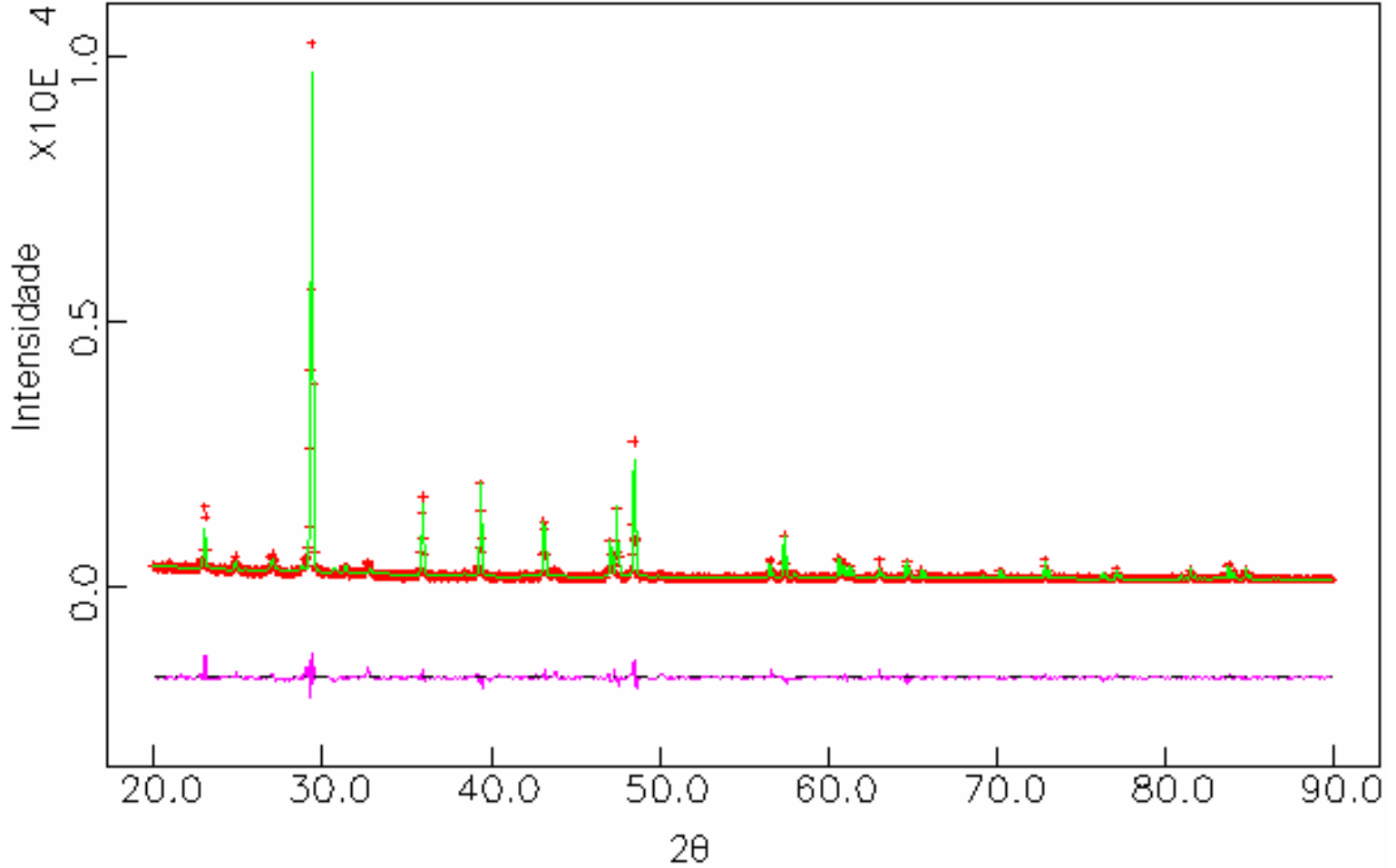

Figura 120- Gráfico de Rietveld para os cristais formados em presença de Gly $\left(1 \mathrm{mg} \cdot \mathrm{mL}^{-1}\right)$. 


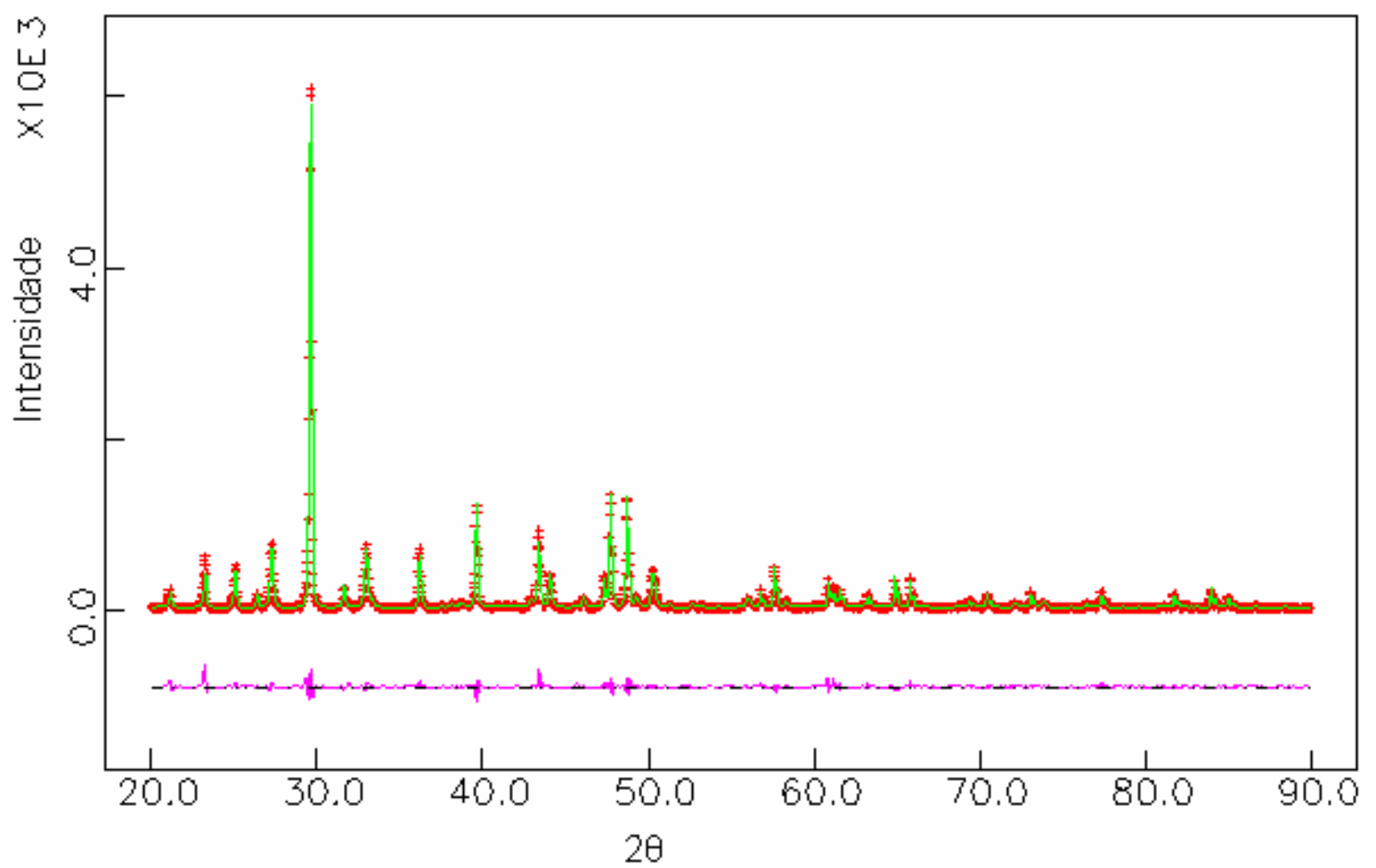

Figura 121 - Gráfico de Rietveld para os cristais formados em presença de Ser $\left(0,1 \mathrm{mg} \cdot \mathrm{mL}^{-1}\right)$.

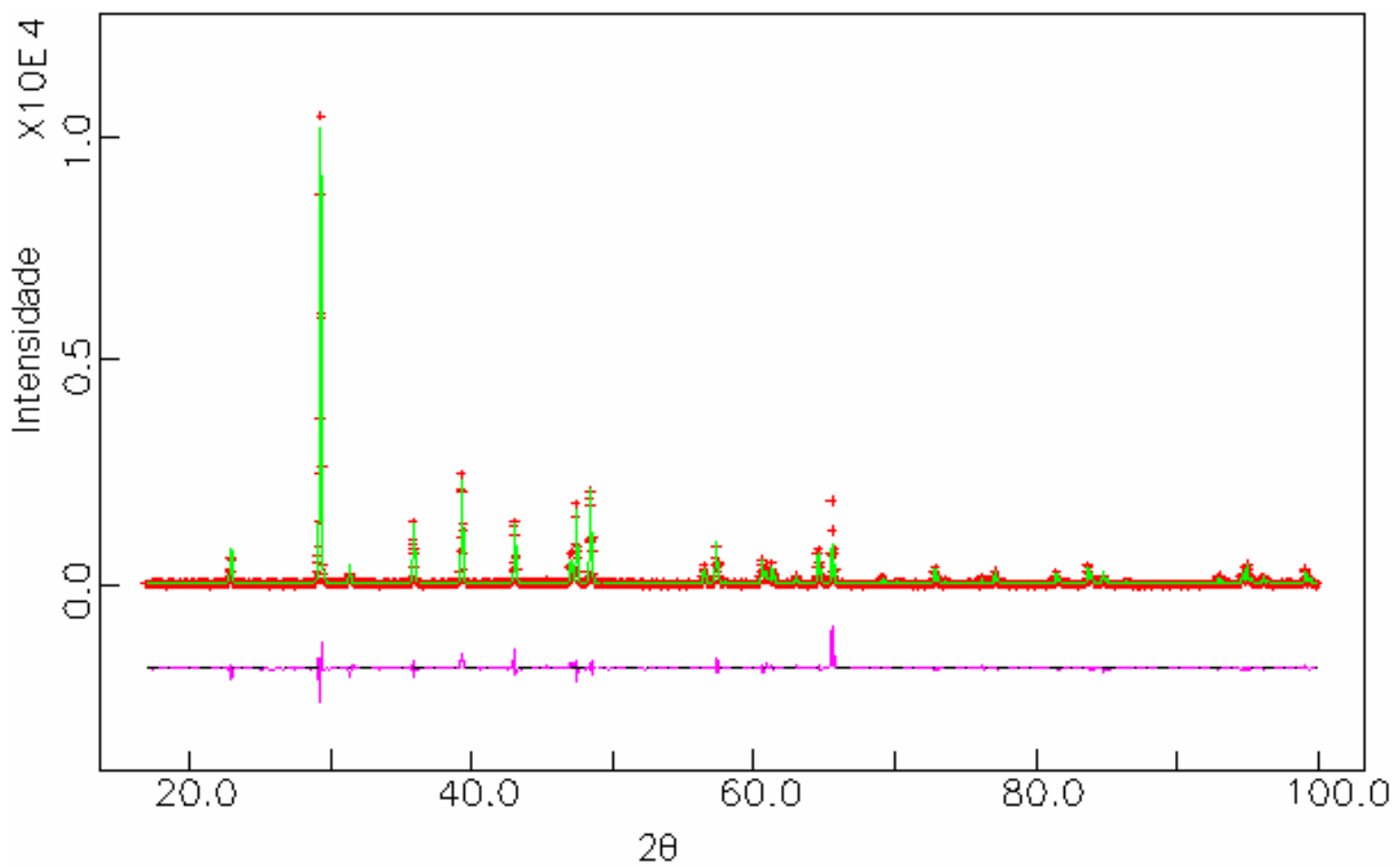

Figura 122- Gráfico de Rietveld para os cristais formados em presença de Ser $\left(1 \mathrm{mg} \cdot \mathrm{mL}^{-1}\right)$. 


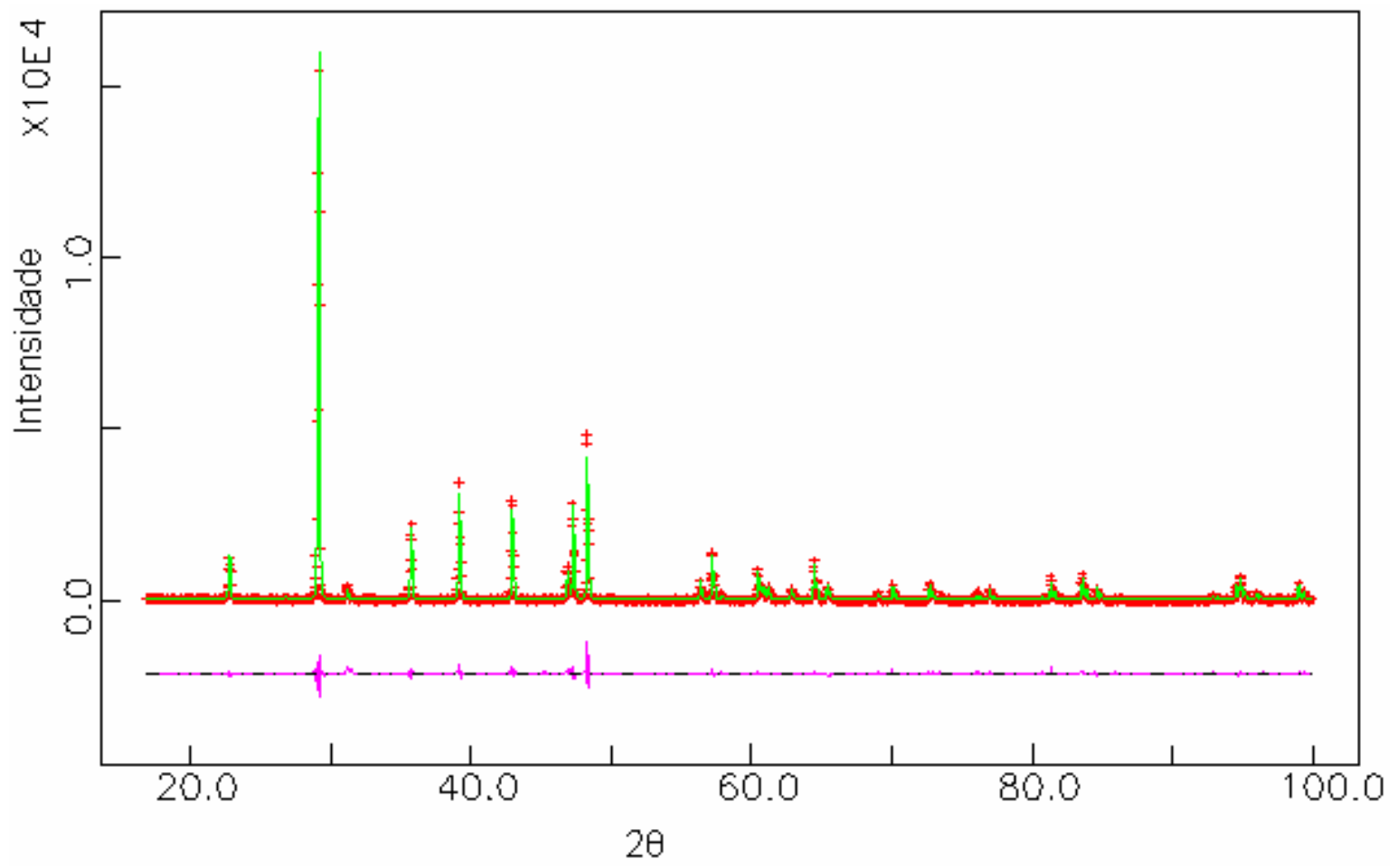

Figura 123 - Gráfico de Rietveld para os cristais formados em presença da matriz orgânica insolúvel.

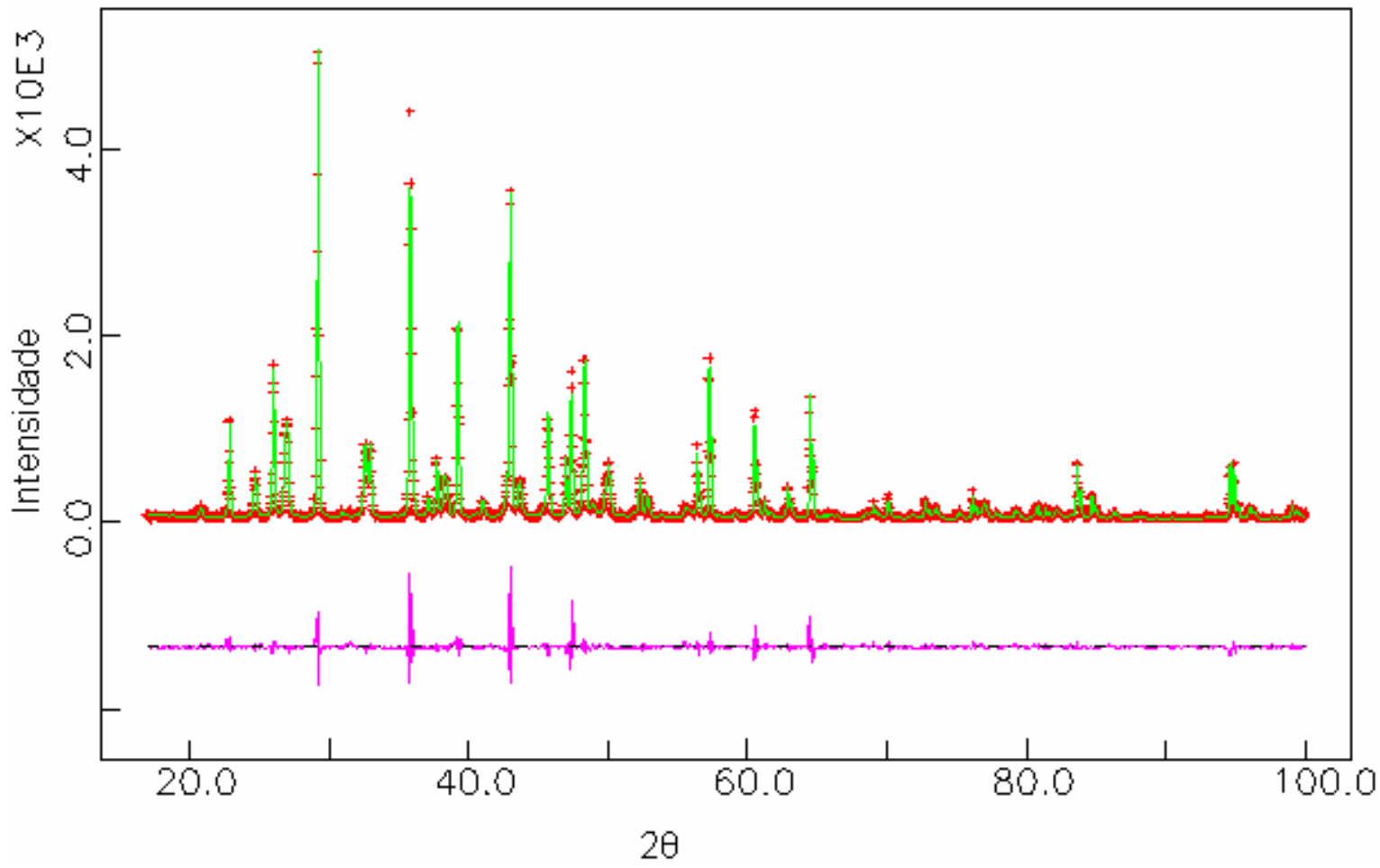

Figura 124 - Gráfico de Rietveld para os cristais formados em presença da fração orgânica solúvel. 


\section{Espectroscopia de infravermelho (IV)}

$\mathrm{O}$ espectro de infravermelho para os cristais crescidos na solução de $\mathrm{CaCO}_{3}$ contendo magnésio (Figura 125 controle A), mostra picos característicos da aragonita em $1083 \mathrm{~cm}^{-1}, 854 \mathrm{~cm}^{-1}, 712 \mathrm{~cm}^{-1}, 700 \mathrm{~cm}^{-1}$. Os demais picos, em $1385 \mathrm{~cm}^{-1}, 1557 \mathrm{~cm}^{-1}, 1790 \mathrm{~cm}^{-1}$ $2522 \mathrm{~cm}^{-1}, 2851 \mathrm{~cm}^{-1}$ e $2920 \mathrm{~cm}^{-1}$ também estão associados a esse mineral.

Nas Figuras 125 (Asp, Ser) e 126 (Gly e Glu) são vistos os espectros referentes à adição de ácido aspártico, serina, glicina e ácido glutâmico, respectivamente, à razão de 100mg por L de solução A (com adição de magnésio).

As Figuras 125 (Asp, Ser) e 126 (Gly, Glu) correspondem aos espectros de infravermelho, com picos semelhantes aos obtidos para os cristais crescidos na solução de controle A (Figuras 125, 126). Porém, o pico em $1557 \mathrm{~cm}^{-1}$ não é visto em nenhum dos casos.

$\mathrm{O}$ espectro da Figura 127 (quitina) possui picos em $712 \mathrm{~cm}^{-1}, 872 \mathrm{~cm}^{-1}$, característicos da estrutura da calcita (WHITE, 1974). Com relação à Figura 127 (controle A), há alterações significativas.

A omissão do magnésio na solução de $\mathrm{CaCO}_{3}$ (solução B) produziu picos em $876 \mathrm{~cm}^{-1}, 710 \mathrm{~cm}^{-1}, 2511 \mathrm{~cm}^{-1}, 2872 \mathrm{~cm}^{-1} 2981 \mathrm{~cm}^{-1}$ atribuídos à presença de calcita. O pico de baixa intensidade em $746 \mathrm{~cm}^{-1}$ pode ser atribuído à presença de vaterita; os picos em $1085 \mathrm{~cm}^{-1}$ e $1386 \mathrm{~cm}^{-1}$ são característicos da aragonita (Figura 128, controle B).

A presença de glicina, ácido glutâmico e serina na solução de controle B, proporcionou o aparecimento de picos característicos da calcita, vaterita e aragonita (Figuras 128 Gly e Glu e Figura 129 Ser). Com relação ao espectro para os cristais crescidos na solução de controle B, o ácido glutâmico e a serina produziram picos mais 
intensos em $746 \mathrm{~cm}^{-1}$ e menos intensos nas proximidades de $710 \mathrm{~cm}^{-1}$. O pico próximo de $1386 \mathrm{~cm}^{-1}$ foi notado apenas para a glicina.

Os espectro das Figura 130 (Asp) possui características semelhantes ao espectro da Figura 130 (controle B), porém, sem o pico em $1386 \mathrm{~cm}^{-1}$.

Na Figura 131(Glu) temos um pico intenso em $877 \mathrm{~cm}^{-1}$, que pode estar relacionado à presença de calcita e/ou vaterita, e outros picos de baixa intensidade em 711 e $745 \mathrm{~cm}^{-1}$ associados à calcita e vaterita, respectivamente. Em $1083 \mathrm{~cm}^{-1}$ temos um pico, atribuído à aragonita.

Para o ácido aspártico, há um pico intenso em $874 \mathrm{~cm}^{-1} \mathrm{e}$ dois outros, menos intensos em 712 e $743 \mathrm{~cm}^{-1}$. Esses picos indicam a presença de calcita e vaterita. Picos em 1085, 1383 e $1474 \mathrm{~cm}^{-1} 1$ sugerem a presença de aragonita.

O incremento da concentração de glicina não provocou alterações no espectro de infravermelho, somente o resultado para a $0,1 \mathrm{mg} \cdot \mathrm{mL}^{-1}$ constará nos resultados.

A quitina forneceu para as duas concentrações utlizadas, espectros semelhantes; dessa forma, somente o resultado para a concentração de $1 \mathrm{mg} \cdot \mathrm{mL}^{-1}$ constará nos resultados.

Para o incremento da concentração de serina, há dois picos em $874 \mathrm{~cm}^{-1}$ e $711 \mathrm{~cm}^{-1}$ característicos da calcita (Figura 132 Ser).

A Figura 132 (quitina), apresenta picos associados à calcita em $872 \mathrm{~cm}^{-1} \mathrm{e} 711 \mathrm{~cm}^{-1}$. Na região de $1750-1000 \mathrm{~cm}^{-1}$ a presença desse aditivo provocou alterações significativas com relação ao controle, sem magnésio.

O espectro da Figura 133 (MS) referente aos cristais obtidos pela adição da matriz orgânica solúvel à solução de controle $\mathrm{B}$, indica picos intensos em $874 \mathrm{~cm}^{-1}$ e em $711 \mathrm{~cm}^{-1}$, que são característicos da calcita. Um pico pouco intenso em $1384 \mathrm{~cm}^{-1}$ pode estar associado à presença de aragonita. 
A fração orgânica insolúvel (MI) apresentou picos atribuídos à calcita em $872 \mathrm{~cm}^{-1} \mathrm{e}$ em $709 \mathrm{~cm}^{-1}$ (Figura $\left.133 \mathrm{MI}\right)$. 


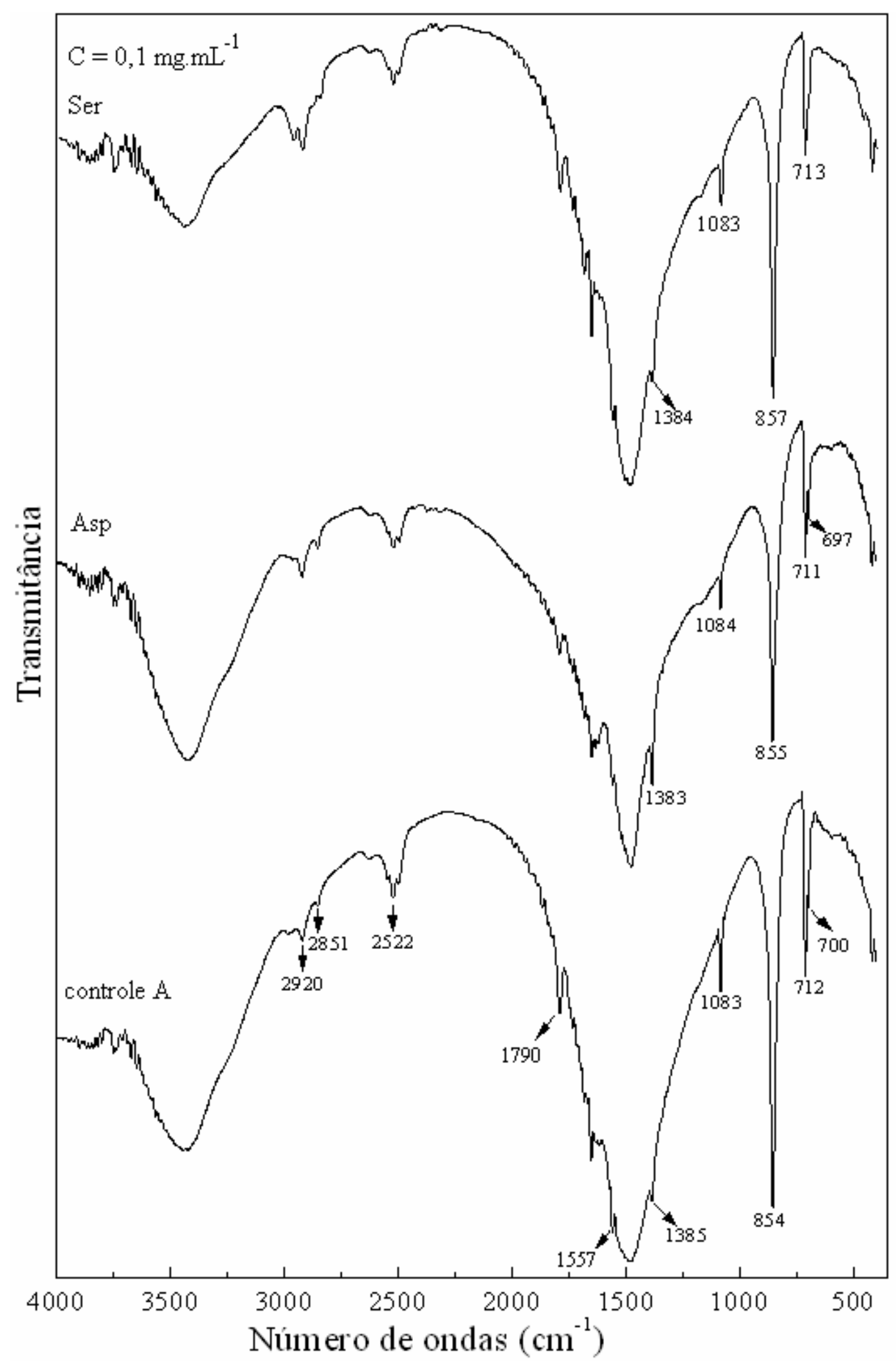

Figura 125 - Espectros de infravermelho para os cristais crescidos na solução contendo $\mathrm{Mg}$ (controle A); para os cristais obtidos pela adição de ácido aspártico (Asp) e serina (Ser). 


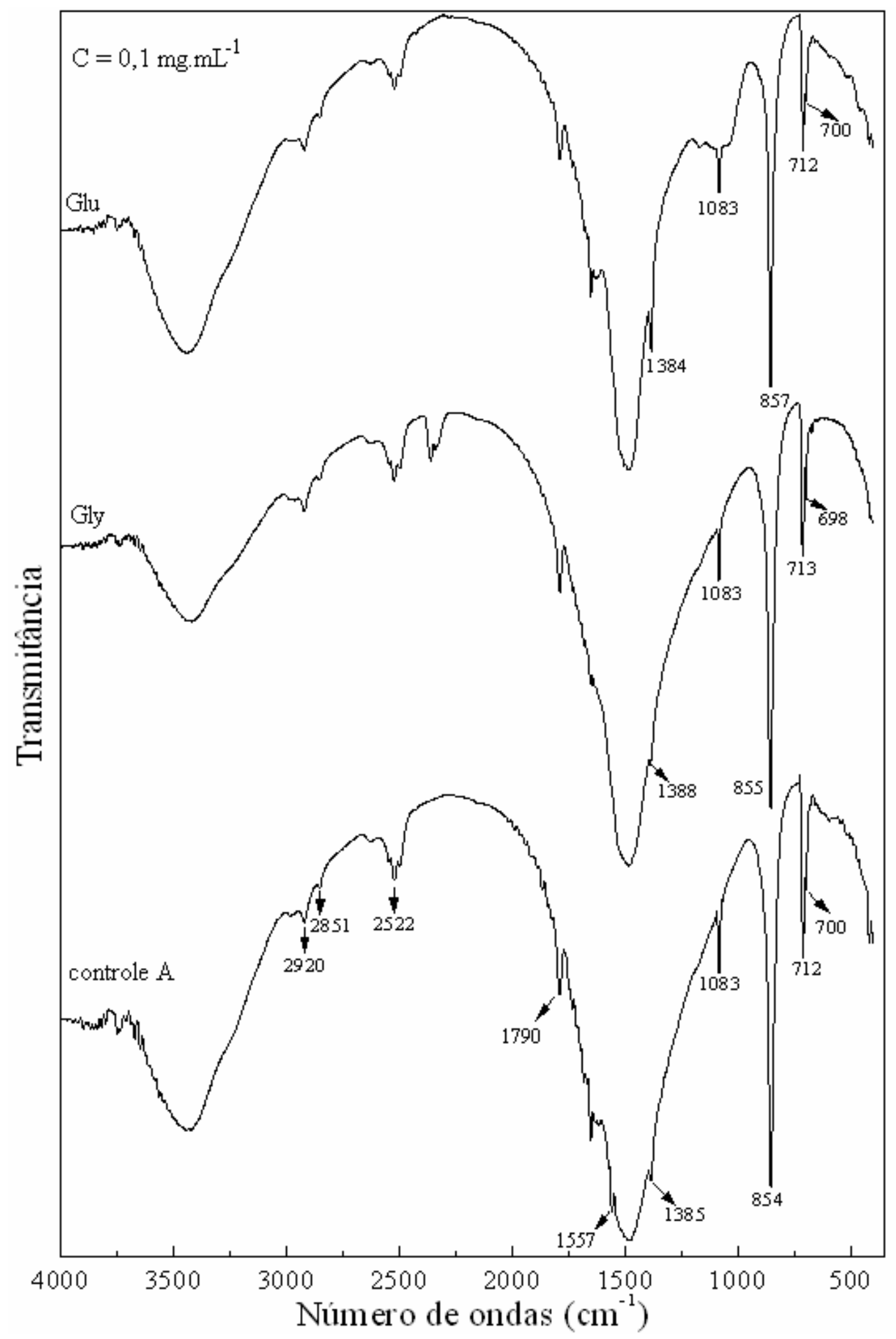

Figura 126- Espectros de infravermelho para os cristais crescidos na solução contendo $\mathrm{Mg}$ (controle A); para os cristais obtidos pela adição de glicina (Gly) e ácido glutâmico (Glu). 


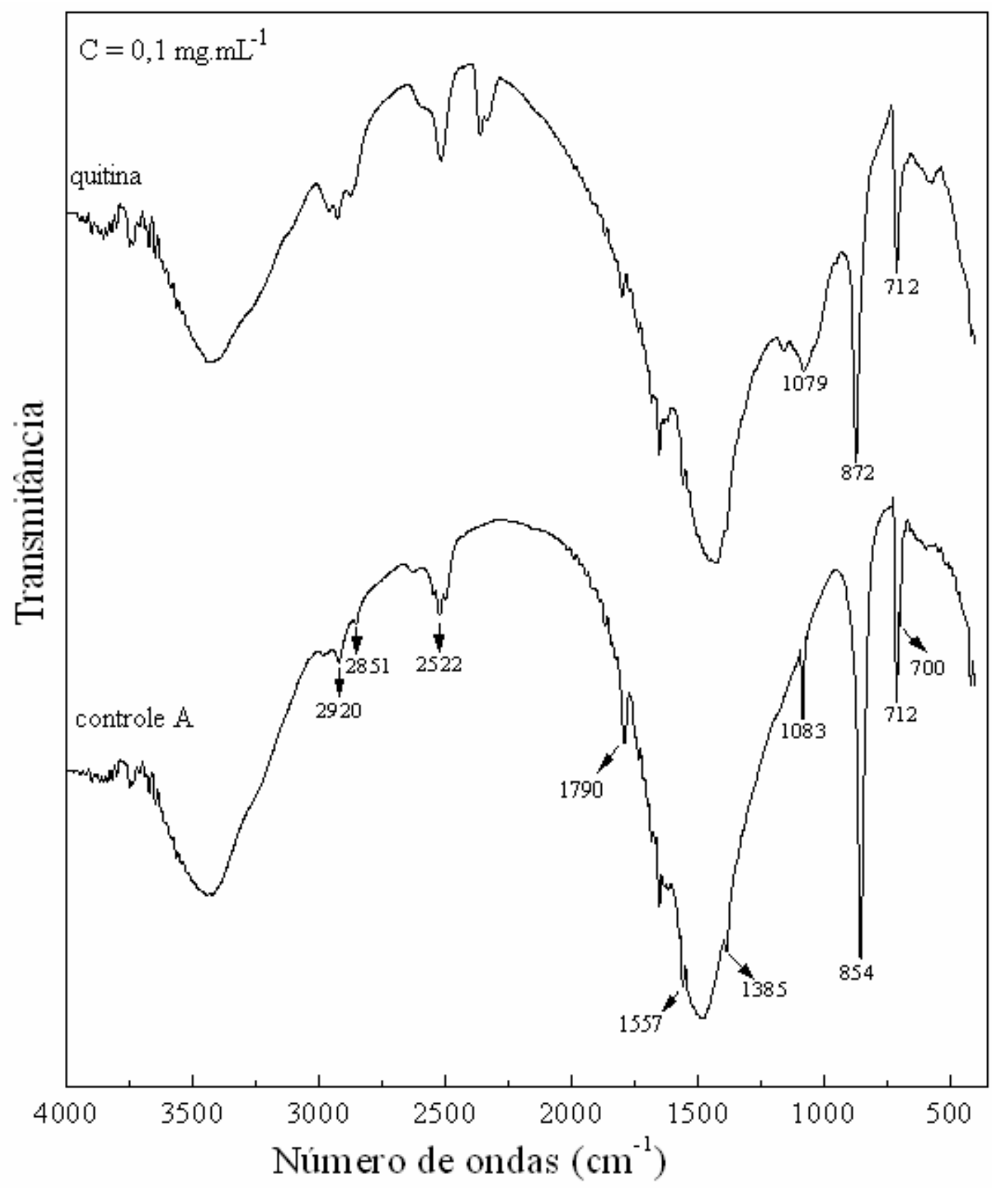

Figura 127 - Espectros de infravermelho para os cristais crescidos na solução contendo $\mathrm{Mg}$ (controle A); para os cristais obtidos pela adição de quitina (quitina) 


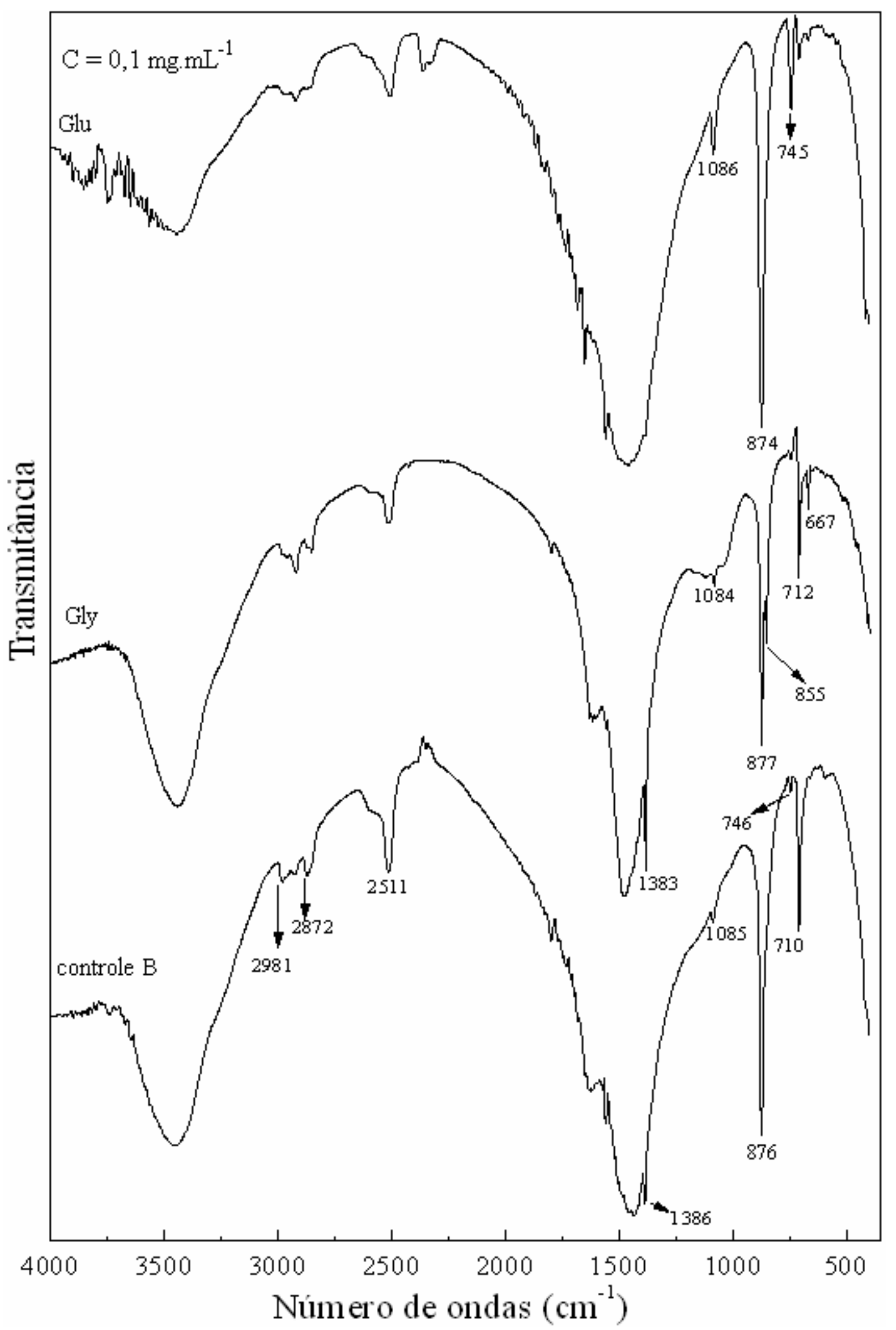

Figura 128 - Espectros de infravermelho para os cristais crescidos na solução sem magnésio (controle B); para os cristais obtidos pela adição de glicina (Gly) e ácido glutâmico (Glu). 


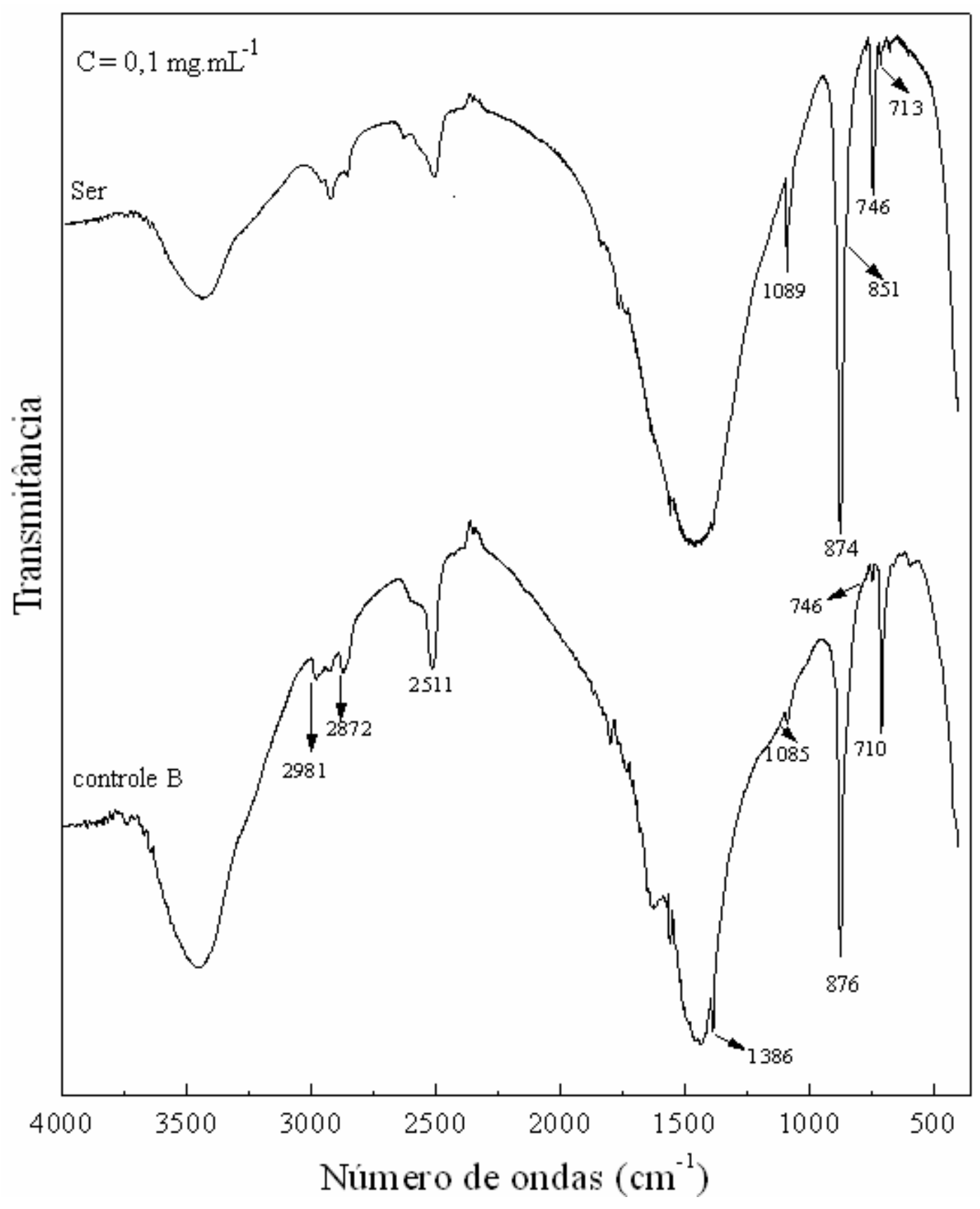

Figura 129- Espectros de infravermelho para os cristais crescidos na solução sem magnésio (controle B); para os cristais obtidos pela adição serina (Ser). 


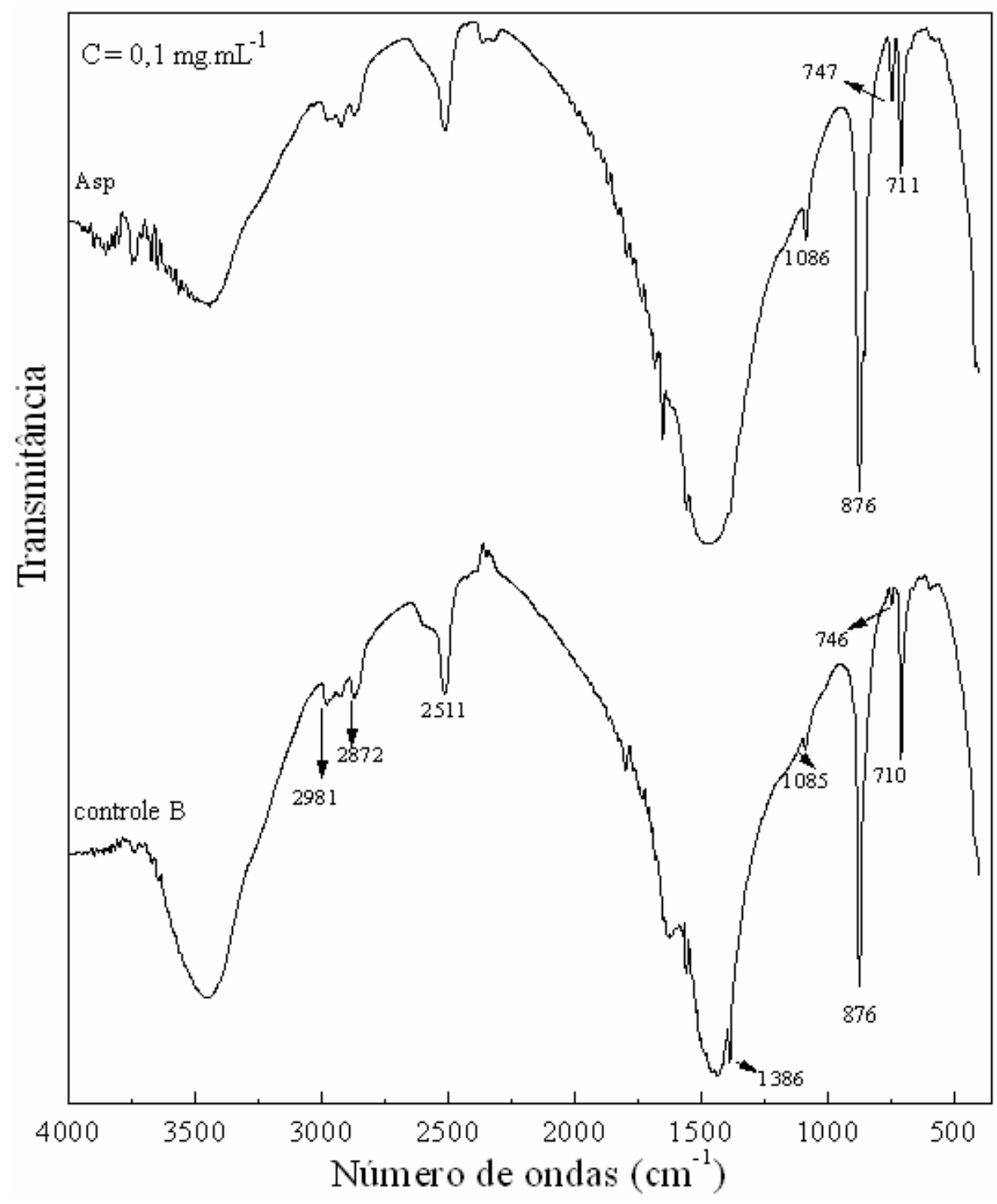

Figura 130- Espectros de infravermelho para os cristais crescidos na solução sem magnésio (controle B); para os cristais obtidos pela adição de ácido aspártico (Asp). 


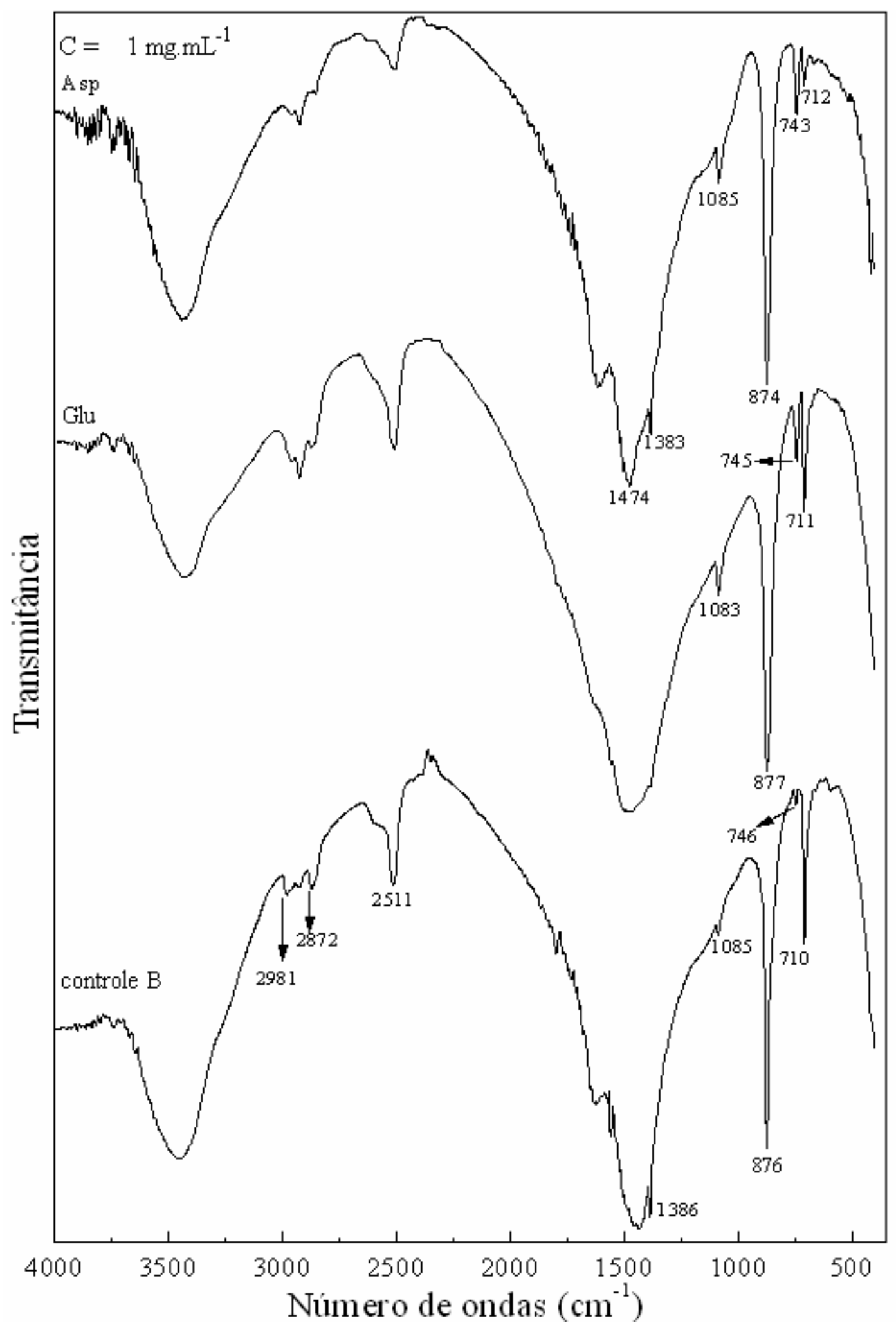

Figura 131- Espectros de infravermelho para os cristais crescidos na solução sem magnésio (controle B); para os cristais obtidos pela adição dos ácidos glutâmico (Glu) e aspártico (Asp). 


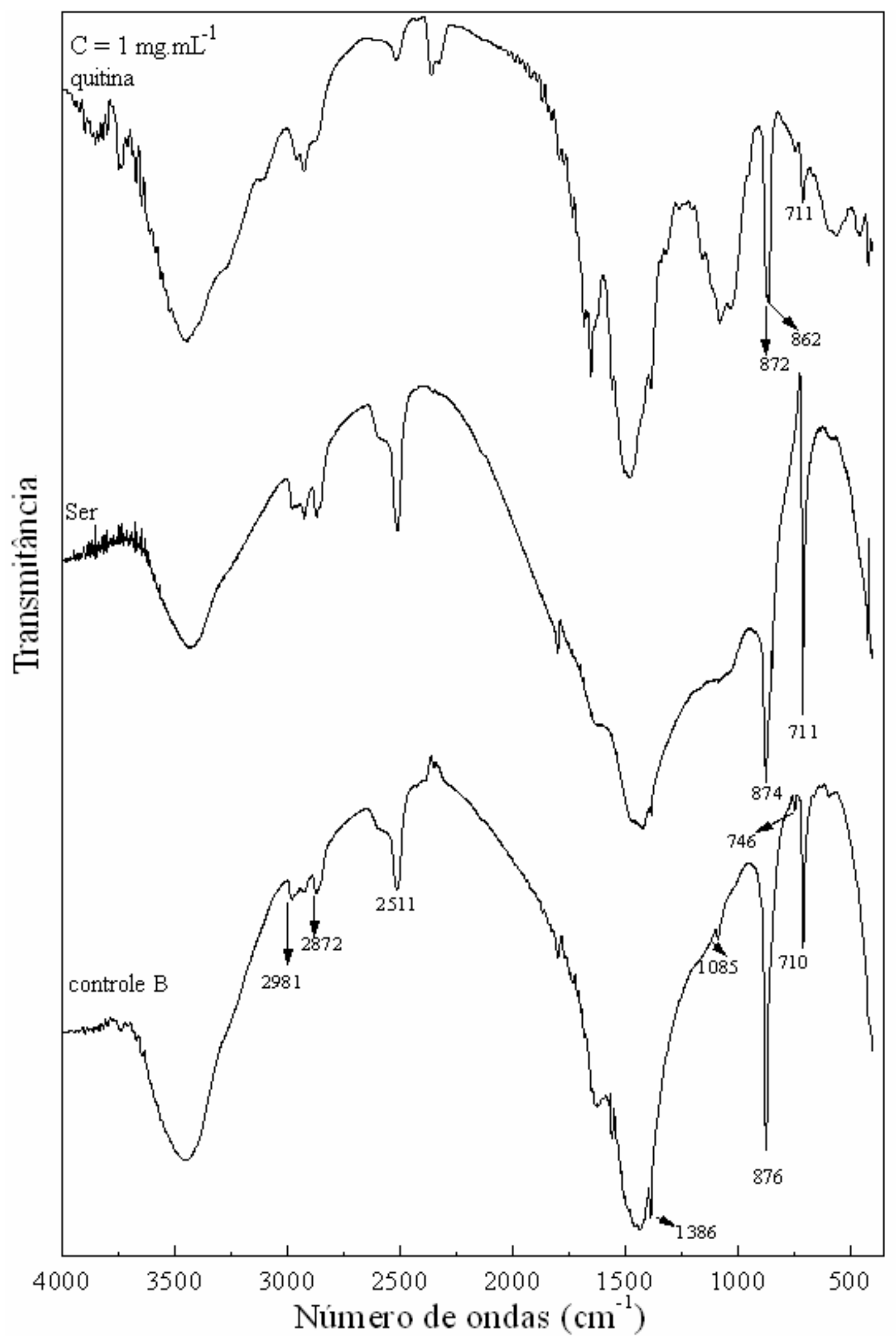

Figura 132- Espectros de infravermelho para os cristais crescidos na solução sem magnésio (controle B); para os cristais obtidos pela adição de serina (Ser) e quitina. 


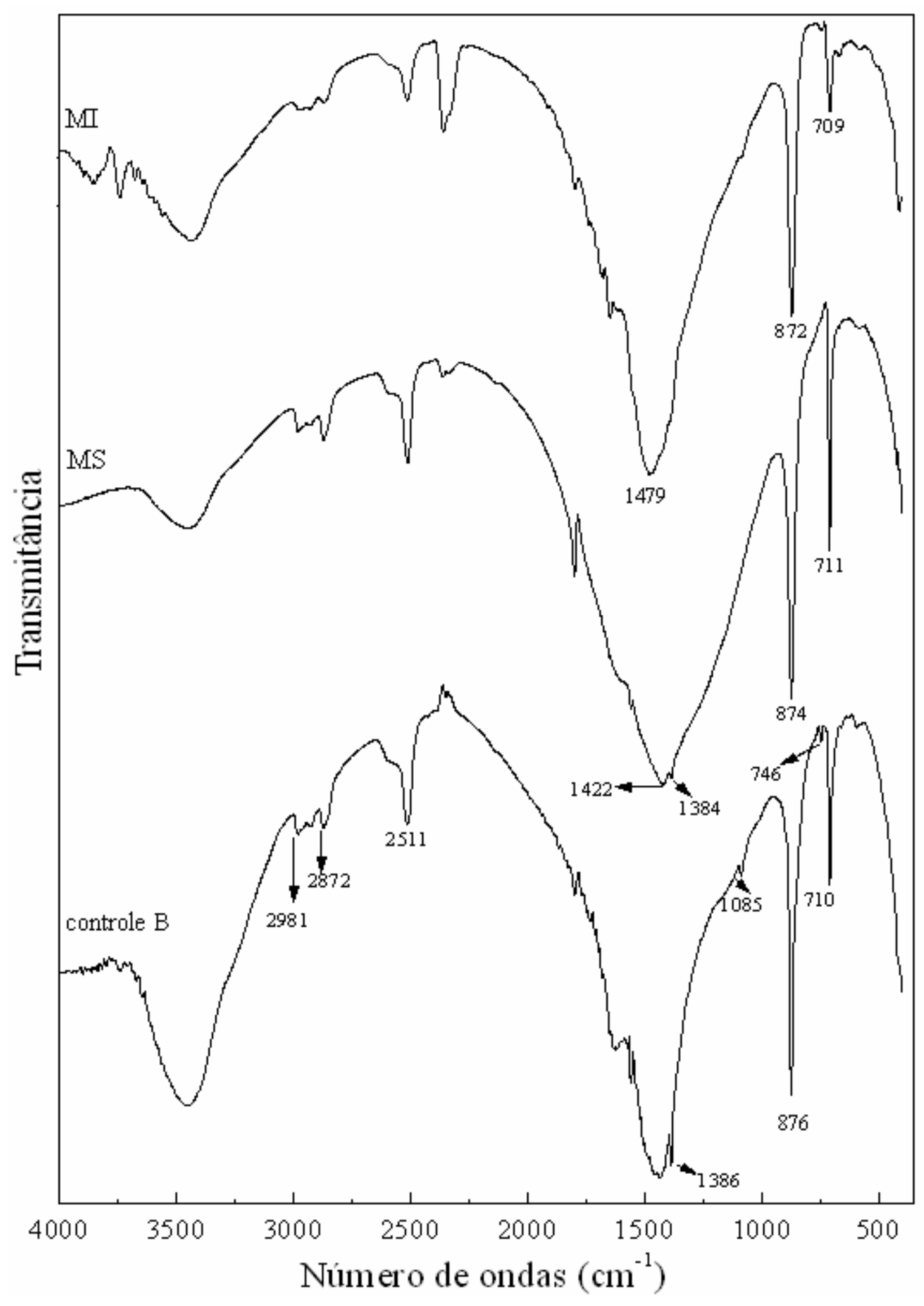

Figura 133- Espectros de infravermelho para os cristais crescidos na solução sem magnésio (controle B); para os cristais obtidos pela adição das matrizes orgânica solúvel (MS) e insolúvel (MI). 


\section{Discussão}

\subsection{Concha do molusco Physa sp.}

O processo de mineralização em conchas de molusco vem sendo estudado intensivamente, sob vários aspectos, por vários autores. A literatura é extensa, o que se pode avaliar pelas revisões mais atuais (FALINI; FERMANI, 2004; MELDRUM, 2003; WILT; KILLIAN; LIVINGSTON, 2003).

Consideramos interessante investigar o gastrópode Physa, bastante comum em nosso ambiente, traçando um paralelo entre as propriedades da concha e a mineralização induzida em laboratório.

A microestrutura da concha da Physa sp. não foi explorada em outras publicações; há na literatura, apenas investigações sobre o perióstraco deste caracol (JONES; SALEUDDIN, 1978). Em publicação recente (DE PAULA; SILVEIRA, 2005a) já relatamos aspectos morfológicos e polimórficos dos cristais de carbonato de cálcio da concha deste organismo. A ação de vários agentes orgânicos presumivelmente existentes na concha foi também estudada, e os resultados foram apresentados em congressos (Apêndice A).

As conchas de Moluscos apresentam uma complexa micro-estrutura que resulta da deposição pelo próprio organismo, de um biomineral, constituído por cristais de carbonato de cálcio intimamente ligados, com variações morfológicas e organizações arquitetônicas complexas; as propriedades físicas da concha competem e muitas vezes superam, aquelas de materiais de origem abiótica; os componentes cristalinos crescem mediados por uma 
matriz orgânica delicada, que exerce função importante no processo mineralizante (BIRCHALL, 1989).

Externamente a concha é recoberta pelo perióstraco, que é uma película orgânica fina, mostrando variações estruturais de coloração e textura (LOWENSTAM; WEINER, 1989). Nos moluscos bivalves há três camadas no perióstraco (SALEUDDIN; PETIT, 1983). De acordo com Checa (2000), haveria apenas duas camadas. Os gastrópodes de água doce, como é o caso da Physa, possuem número maior de camadas que os marinhos, e esse número depende também do estágio de desenvolvimento da concha (WATABE, 1984).

As observações feitas em cortes ultrafinos no presente caso, mostraram que o perióstraco da concha em Physa, medindo $9 \mathrm{~mm}$ de comprimento, tem cerca de $1 \mu \mathrm{m}$ de espessura, e é formado por uma camada homogênea, uma camada lamelar e outra sublamelar. Tais estruturas concordam com o descrito por Jones e Saleuddin (1978), exceto nas dimensões, que podem apresentar variação de acordo com o estágio de desenvolvimento do molusco.

Quanto à composição química, o perióstraco possui proteínas, lipídeos, polissacarídeos (MEENAKSHI et al., 1969) e cálcio (SALEUDDIN; PETIT, 1983). Há registros da presença de ferro (Fe) e cádmio (Cd) no perióstraco de Mytilus edulis (WATABE, 1984).

As análises da composição química do perióstraco da Physa sp., indicaram a presença de polissacarídeos, cálcio e fósforo, este último relacionado ao material fibroso encontrado na superfície externa; este material possivelmente está associado à fosfatase ácida, de acordo com Jones e Saleuddin (1978). 
Na superfície externa do perióstraco de conchas jovens, e apenas aí, observamos unidades circulares homogêneas e pacotes orgânicos, estruturas essas que desaparecem na fase adulta (DE PAULA; SILVEIRA, 2003, 2005a). De acordo com Rousseau et al. (2005), tal estrutura existe na camada nacarada da ostra Pinctada. Na Physa porém, essas unidades aparecem apenas na superfície externa da concha, como placas circulares.

Em imagens feitas por transmissão, mostramos que após descalcificação completa, as unidades circulares permanecem na amostra; a micro-análise correspondente a essa região indicou a presença de $\mathrm{C}, \mathrm{O}, \mathrm{S}$ e $\mathrm{Mn}$, sugerindo que a matriz orgânica que precede a formação das unidades circulares possui a mesma morfologia e os pacotes circulares porosos vistos por MEV são de fato, orgânicos.

Usando MEV, verificamos que existem 5 camadas calcárias localizadas abaixo do periostraco, como apresentamos no modelo esquemático. São formadas por prismas, que segundo Taylor e Kennedy (1969), em algumas espécies, desenvolve-se a partir de esferulitos localizados próximos do perióstraco, por lamelas e pela camada nacarada.

$\mathrm{Na}$ primeira camada existem prismas verticais; cristais de aragonita com morfologia que se assemelha a agulhas, também observados na concha do molusco Spengleria rostrata (CARTER, 1980); abaixo da camada lamelar, há prismas, regularmente orientados. Segundo ${ }^{5}$ Bǿggild (1930 apud WATABE, 1984, p. 451), a orientação dos prismas é relativamente uniforme, porém, existem consideráveis variações de acordo com a espécie do molusco . Na concha do molusco Pinna bicolor Gmelin há prismas regulares de calcita; na camada interna do Divalucina cumingi, prismas irregulares de aragonita, prismas

\footnotetext{
${ }^{5}$ BǿGGILD, O.B. The Shell structure of the mollusks. K Dan Vidensk Selsk Skr Naturvidensk Math Afd 9 Raekke, v.2, p.231-326, 1930.
} 
fibrosos são vistos no Faragum subretusum (CARTER, 1980) e prismas verticais no Turbo petholatus (CHATEIGNER; HEDEGAARD; WENK, 2000) .

A camada lamelar é a mais comum das estruturas encontradas nas conchas de moluscos. Pode apresentar-se como camada lamelar de primeira ordem, constituída por placas e de segunda ordem, constituída por lamelas orientadas, inclinadas em duas direções $\left(90^{\circ}-130^{\circ}\right)($ SALEUDDIN, 1983; SIMKISS; WILBUR, 1989).

Abaixo da camada prismática, reconhecemos duas camadas lamelares de segunda ordem; uma camada constituída por lamelas de primeira ordem são vistas na região interna do ápice. Dauphin e Denis (2000) investigaram a morfologia dessa estrutura em três gástrópodes e três bivalves: constataram que essas carapaças possuem uma estrutura complexa composta por lamelas com orientações alternadas. O bivalve Dosinia ponderosa, apresenta camada lamelar de primeira ordem semelhante às nossas observações.

O desenvolvimento da camada nacarada apresenta variações entre os gastrópodes e bivalves porém, em ambos os casos, inicia-se por uma distribuição de pequenos cristais (SIMKISS; WILBUR, 1989). Nas conchas de gastrópodes essa camada contém tabletes de aragonita separados por membranas orgânicas inter-lamelares, contendo em sua região central por um acúmulo de matéria orgânica (MUTVEI, 1978,1980).

O organismo aqui investigado apresenta em seu estágio inicial, a camada nacarada constituída por ondulações (DE PAULA; SILVEIRA, 2005a, b) e em conchas adultas, por tabletes poligonais empilhados. Embora, vários autores descrevam que esse arranjo seja seguido por prismas (BLANK et al., 2003; DIMASI; LI et al., 2004; LIN; MEYERS, 2005). Observamos na Physa lamelas e esferas em contato com essa camada. São necessárias maiores observações para concluirmos se essas esferas precedem ou não a formação das lamelas, ou ainda, se desenvolvem simultaneamente às lamelas em 
localidades específicas da concha. Tal organização não foi relatada na literatura até o momento.

Além das estruturas cristalinas descritas, várias outras ocorrem na Physa. Na abertura, ocorrem cristais folheados, organizados em bandas paralelas semelhantes aos vistos no bivalve Propeamussium dalli (HALL et al., 2002).

$\mathrm{Na}$ região interna do ápice, ripas são notadas em grande quantidade; poliedros e romboedros com faces bem formadas estão em contato com a matriz orgânica, evidenciando a íntima relação entre a matriz e o crescimento dos cristais de carbonato de cálcio. Tais morfologias são vistas também na columela (DE PAULA; SILVEIRA, 2004a). Watabe (1981) descreve em seu trabalho, cristais de calcita romboédrica na concha da Cepaea nemoralis.

Encontramos lamelas organizadas em agregados esféricos sobre prismas distribuídas internamente, por toda a parede da concha. Não há registros dessa organização em outros moluscos.

A morfologia da matriz orgânica insolúvel, investigada por MEV e MET, exibiu uma delicada película que recobre lamelas e prismas. Na camada nacarada a matéria orgânica está em contato com esferas. Após completa descalcificação, observou-se além de uma fina película, grande quantidade de fibras. Vários trabalhos sobre a estrutura morfológica da matriz orgânica têm sido publicados. Grégoire (1967), descreve detalhadamente a matriz orgânica presente nas camadas prismática, lamelar e nacarada de várias espécies de moluscos. Dentre estas, podemos citar a matriz fibrilar do molusco Nautilus pompilius e a matriz intra-cristalina estudada por Tong et al. (2002), que são morfologicamente semelhantes às matrizes encontradas na Physa. 
O componente orgânico exerce importante função no processo de cristalização do $\mathrm{CaCO}_{3}$, sendo responsável pelo polimorfismo, morfologia e orientação dos cristais (ALBECK; AIZENBERG; ADDADI; WEINER, 1993; CLARK II, 1999; FALINI; FERMANI; RIPAMONTI, 2002; THOMPSON et al.,2000; WATABE, 1963,1965). Há na literatura estudos recentes sobre a natureza química da fração solúvel (ALBECK, WEINER; ADDADI, 1996; PEREIRA-MOURIÉS et al., 2002) porém, com relação à fração insolúvel, poucos trabalhos foram publicados nos últimos anos (LOWENSTAM; WEINER, 1989; SUDO et al., 1997).

Nosso estudo do componente orgânico insolúvel por espectroscopia de infravermelho, apresentou vibrações atribuídas às amidas e aos polissacarídeos, encontrados com freqüência na composição orgânica solúvel dos moluscos (MARXEN; BECKER, 1997; DAUPHIN, 2003; PEREIRA-MOURIÉS et al., 2002); picos de baixa intensidade para o sulfato, que está presente na matriz orgânica (DAUPHIN, 2001, 2003) e no fluido extrapalial de várias espécies de molusco (CRENSHAW,1972; SALEUDDIN, 1983; WATABE, 1981) e fosfato, encontrado em pouca quantidade nas camadas prismáticas e lamelar do gastrópode Concholepas concholepas (DAUPHIN et al., 2003).

O cruzamento dos resultados do teste histoquímico, da microanálise e do espectro de infravermelho, garantiram maior confiabilidade dos resultados para os polissacarídeos, sulfato e fosfato, representados por picos com baixa intensidade.

Vários trabalhos sobre a composição orgânica solúvel foram publicados para diferentes espécies de moluscos (HARE, 1963; MARIN; LUQUET, 2004; WEINER, 1979, 1983) porém, apesar de preliminares, os presentes resultados da análise de aminoácidos são importantes porque são os primeiros referentes à tentativa de caracterizar os aminoácidos presentes na Physa sp. Não foi possível a quantificação dos resultados 
devido à pouca quantidade de matéria orgânica solúvel e por não termos, neste momento, um equipamento disponível para a análise.

O aminograma demonstrou a glicina, serina e ácido aspártico em maior quantidade. De maneira geral, o ácido aspártico é encontrado em maior quantidade nas carapaças dos moluscos (WEINER, 1975). Porém, nossas análises indicaram a glicina, em maior proporção. A serina e o ácido aspártico também apresentaram picos intensos.

Conhecer a composição da matéria orgânica é um fator relevante no estudo da biomineralização; de acordo com a camada, temos diferenças na composição dos aminoácidos (KAPLAN, 1998). Gregorie (1961) estudou 22 espécies de moluscos e concluiu que há diferenças entre a matriz orgânica da camada de calcita com relação à que contém aragonita.

Segundo Hare (1963), a camada nacarada do bivalve Mytilus possui glicina, alanina e ácido aspártico em grande quantidade e a camada prismática é constituída por glicina, alanina e serina. Recentemente, Marin e Luquet (2004) identificaram os ácidos aspártico, glutâmico e a glicina como os aminoácidos presentes em maior quantidade na camada prismática do molusco Pinna nobilis $L$.

A análise de aminoácidos da Physa não permitiu associar os resultados às camadas nacarada, prismática ou lamelar, porque a fração orgânica foi extraída da concha inteira. Devido á dimensão da concha, não houve separação por camadas. Porém, informações contidas na literatura sugerem que a glicina favoreça a formação da aragonita (WEINER, 1983; WILBUR; YONGE, 1964), o que está coerente com o fato da concha investigada neste trabalho possuir basicamente esse polimorfo em sua constituição carbonácea.

Para a melhor compreensão da biomineralização, é necessário investigar não somente a relação entre o $\mathrm{CaCO}_{3}$ e os componentes orgânicos, mas também, a ação dos 
componentes inorgânicos encontrados nas carapaças calcárias no processo de formação dos cristais.

Para a determinação quantitativa dos componentes inorgânicos, foi utilizado o método de análise por ativação de nêutrons, capaz de detectar grande parte dos elementos da tabela periódica com sensível precisão, assim identificando desde concentrações em porcentagem até níveis de traços. Não há na literatura resultados sobre a composição inorgânica do molusco Physa sp. Identificamos Ba, Br, Ca, Mn, Na, Sr e Zn.

Dentre os elementos identificados em maior proporção, temos o $\mathrm{Ca}$, relacionado ao fato das carapaças apresentarem predominância esperada de $\mathrm{CaCO}_{3}$ superior a 95\%; alem deste encontrou-se o $\mathrm{Na}$ e o $\mathrm{Sr}$, também presentes em várias espécies de moluscos e geralmente relacionados à presença de aragonita. São encontrados em alta concentração na estrutura lamelar e na camada nacarada das carapaças dos moluscos Glycymeris Glycymeris e Cerastoderma glaucum e na camada prismática do Mytilus galloprovincialis (WATABE, 1984). Os cátions Mn e Zn, verificados em menor concentração, tendem a cristalizar a calcita (WATABE, 1984). Dauphin et al. (2003) descrevem a presença de Mn na camada prismática do gastrópode Concholepas concholepas. Dentre os elementos identificados, apenas o Br não foi registrado na camada calcificada das conchas de outros moluscos, é possível que esse elemento na Physa tenha sido adsorvido do meio ambiente.

Os elementos presentes em conchas de $0,5 \mathrm{~mm}$ de altura foram identificados somente por microanálise. A análise por ativação neutrônica necessita de 50-200mg de amostra, inviável nesse caso.

Na fase inicial do desenvolvimento, a Physa possui em sua constituição inorgânica os elementos $\mathrm{Mg}, \mathrm{Al}, \mathrm{Si}, \mathrm{Ca}, \mathrm{Fe}, \mathrm{Cu}, \mathrm{Zn}$ e $\mathrm{Mn}$. Dentre estes, apenas o $\mathrm{Ca}$ e o $\mathrm{Zn}$ são constituintes também identificados em conchas adultas. 
Estudos pioneiros de ${ }^{6}$ Bǿggild (1930 apud WILBUR, 1964, p. 264-265), estabeleceram que toda concha aragonítica possui baixa concentração de magnésio. Para as carapaças compostas essencialmente por calcita, essa regra não é válida; pode-se verificar alta ou baixa concentração de magnésio. Estudos recentes mostraram que a adição adequada de íons $\mathrm{Mg}$ solução de $\mathrm{CaCO}_{3}$ de fato, induz a cristalização da aragonita (MATSUSHIRO et al., 2003; MELDRUM, 2003; MELDRUM; HYDE, 2001).

Porkroy et al. (2004) associou o Si, encontrado na concha do bivalve Acanthocardia tuberculata à aragonita. Os íons $\mathrm{Al}, \mathrm{Cu}$ e Fe sugerem que a calcita faça parte da constituição de algumas espécies de moluscos. Dauphin et al. (2003) localizaram Al e Fe, além de outros elementos químicos, nas camadas prismáticas e lamelares do $C$. concholepas.

Na Natureza, a biomineralização ocorre a partir de sistemas tendo composição química complexa. As variações na constituição dos componentes inorgânicos estão relacionada com a espécie, idade e fisiologia do organismo, bem como aspectos bioquímicos e da mineralogia da concha (MAI et al., 2003; WATABE, 1984).

Nos carbonatos, existe a troca de um íon, ou grupo de íons por outros íons ou grupos de íons. Alguns cátions metálicos, como o $\mathrm{Mg}, \mathrm{Fe}, \mathrm{Mn}$ podem substituir o Ca na calcita, isso porque esses cátions possuem raios medindo respectivamente $0,66 \AA, 0,74 \AA$ e

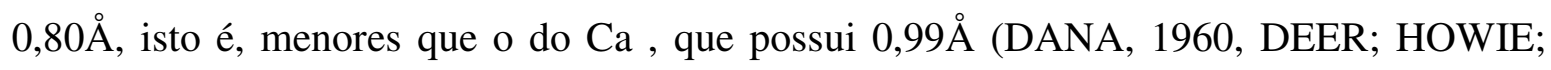
ZUSSMAN, 1981). Esses cátions inicialmente podem parecer estranhos à composição química do mineral, sendo tratados como impurezas, mas na realidade, fazem parte da estrutura do mineral, ocupando o lugar de outro cátion.

${ }^{6}$ BǿGGILD, O. B. The Shell structure of the mollusks. Kgl. Danske Videnskab. Selskabs, Skrifier Naturvidenskab. Math Afdel. v.2, p.232-325, 1930. 
À medida que a diferença entre os raios dos íons aumenta, a dificuldade para substituí-los em uma troca iônica é maior. $\mathrm{O} \mathrm{Ca}$ e o $\mathrm{Mg}$ possuem uma diferença em seus raios de cerca de $33 \%$, o que dificulta cristalizar a calcita em presença de $\mathrm{Mg}$ ou a magnesita em presença de Ca (DANA, 1960).

Alguns íons, como o $\mathrm{Sr}, \mathrm{Na}$ e Ba respectivamente com raios de $1,12 \AA, 0,97 \AA \mathrm{e}$ $1,34 \AA$, tendem a cristalizar a aragonita. Em presença de $\mathrm{Sr}$, a possibilidade de aragonita recristalizar como calcita, é remota, a menos que todo Sr seja removido, isso porque a calcita aceita íons com raios menores que o do Ca (DANA, 1960; DEER; HOWIE, ZUSSMAN, 1981).

Em resumo, podemos dizer que as estruturas dos minerais do grupo dos carbonatos, são dependentes das dimensões dos raios dos íons; quanto menor a diferença entre eles, mais fácil será a substituição de íons. Se o raio exceder a 1,0 , temos a estrutura ortorrômbica e para os raios menores, a estrutura romboédrica. Outros fatores como a temperatura e valência dos íons também devem ser avaliados.

Nossas investigações sobre a composição inorgânica não permitiram associar os íons às camadas, mas trouxeram dados importantes sobre o polimorfismo do carbonato de cálcio, em dois estágios distintos do desenvolvimento da Physa. Independente da idade, verificamos existir aragonita e calcita na constituição carbonácea da concha.

Para a quantificação das fases cristalinas, utilizamos a difração de raios-X, pelo método do pó, com os dados ajustados pelo método de Rietveld. Estudamos por essa metodologia, a posição dos picos de difração que dependem do comprimento de onda utilizado e de suas intensidades, que são dependentes das posições dos átomos na cela unitária. É possível refinar a estrutura cristalina e as características do perfil da reflexão. 
$\mathrm{O}$ valor $\mathrm{S}=1,816$, correspondente à qualidade do ajuste, não apresentou um valor baixo (próximo de 1,0), o que pode estar associado ao fato de a amostra possuir cristais em forma de agulhas nas proximidades do perióstraco e placas distribuídas em algumas camadas, gerando forte orientação preferencial. Porém, os índices $\mathrm{R}_{\mathrm{wp}}$ (valor ponderado) foi 0,069 e $\mathrm{R}_{\exp }($ valor experimental $)=0,038$, indicam boa qualidade do refinamento.

A análise quantitativa foi baseada em todos os picos do espectro, todos eles ajustados, o que nos forneceu maior confiabilidade dos resultados. Obteve-se para a aragonita $99,20 \%$ e para a calcita, apenas $0,80 \%$, que pode ser associada aos cristais romboédricos vistos em algumas regiões da concha.

Hasse et al. (2000), registraram a ocorrência de esferas na superfície interna de conchas adultas do molusco Biomphalaria glabrata, que foram identificadas como vaterita. Formas esféricas semelhantes localizadas nas camadas internas da Physa, são provavelmente, calcita (DE PAULA; SILVEIRA, 2005a).

Investigações do polimorfismo do carbonato de cálcio por difração de raios-X foram relatadas por vários autores (FENG et al., 2000; FU et al, 2005; WANG et al, 2003; ZOLOTOYABKO, QUINTANA, 2002). Apesar de ser importante para a análise de difratogramas, o método de Rietveld não é utilizado em grande escala pelos grupos que investigam o processo da biomineralização em moluscos. Podemos citar Hasse et al.. (2000, 2002) que quantificaram as fases do $\mathrm{CaCO}_{3}$ nos moluscos Biomphalaria glabrata e Helix pomatia .

A quantificação das fases é importante, visto que, juntamente com outras técnicas, a maior parte delas aplicadas neste trabalho, pode-se associar a presença de material orgânico e de íons à cristalização da aragonita, calcita ou quando for o caso, à vaterita, encontrada com menor freqüência nas conchas de moluscos. 
Por espectroscopia de infravermelho, confirmamos a presença da aragonita. Análises por difração de elétrons permitiram identificar aragonita ortorrômbica e calcita romboédrica, o que nos garantiu maior segurança aos resultados. 


\subsection{Cristalização do carbonato de cálcio.}

Neste trabalho, os cristais crescidos in vitro foram caracterizados por microscopia eletrônica de varredura e microscopia óptica de luz. Essas técnicas, amplamente utilizadas por vários pesquisadores (AIZENBERG et al.., 2002; KANAKIS; DALAS, 2000; MANOLI; DALAS, 2000; NAKA; CHUJO, 2001), contribuem com importantes informações morfológicas, como alterações nas faces dos cristais, modificações do hábito cristalino, que nem sempre é acompanhada por alterações do polimorfismo e inibição da cristalização.

O polimorfismo dos cristais foi avaliado por espectroscopia de infravermelho, por difração eletrônica e difração de raios-X.

Nos diversos artigos citados neste trabalho, os polimorfos presentes nos espectros de raios-X, são identificados por comparação aos padrões da calcita, vaterita e aragonita. Nos casos de superposição de picos é complicado identificar as fases; somente aquela que possuir maior intensidade poderá ser identificada com confiabilidade. O ajuste dos dados pelo método de Rietveld, fornece valores quantitativos das fases cristalinas, até mesmo daquelas presentes em pequena quantidade, proporcionando maiores informações sobre a ação dos aditivos na cristalização do $\mathrm{CaCO}_{3}$. Essa metodologia permitiu verificar a presença de picos estranhos às fases esperadas, que foram atribuídos à presença de contaminações, possivelmente ocorridas durante o preparo da amostra para análise. Quando isso ocorreu, outras amostras foram preparadas, os espectros refeitos e reavaliados.

A cristalização do $\mathrm{CaCO}_{3}$ em presença de $\mathrm{Mg}$ produziu esferulitos em grande quantidade, semelhantes àqueles sintetizados por Choi e Kim (2000). Estes autores 
estudaram a correlação entre os cristais de $\mathrm{CaCO}_{3}$ e a matriz orgânica solúvel extraída das conchas de ostras Crassostrea gigas. Notaram ainda, a presença de lamelas.

O magnésio é um dos íons encontrados em maior proporção nos organismos; acredita-se que esse elemento exerça importante função no processo de cristalização do $\mathrm{CaCO}_{3}$ (HAN; AIZENBERG, 2003). A adição deste elemento em doses adequadas, favorece a cristalização da aragonita (MELDRUM, 2003; XIE; YUAN; SHEN et al.., 2005).

O resultado da difração de raios-X, devidamente ajustado, para os cristais crescidos na solução com magnésio, em nossos experimentos, identificou a aragonita como o polimorfo dominante; todos os picos foram ajustados, garantindo a qualidade do refinamento. Esse resultado foi confirmado pelo espectro de infravermelho, demonstrando os picos característicos da aragonita (WHITE, 1974).

Em presença do ácido glutâmico houve um pequeno incremento da quantidade de calcita; sob a ação de serina, somente a aragonita foi cristalizada. As análises por espectroscopia de infravermelho estão coerentes com os resultados das análises quantitativas dos espectros de raios-X (Tabela 11).

O estudo quantitativo do polimorfismo dos cristais sob a ação dos aminoácidos, não indicou alterações significativas na fase cristalina, o que sugere que apenas o $\mathrm{Mg}$ é suficiente para cristalizar a aragonita.

De todos os aminoácidos selecionados, o ácido aspártico foi aquele que provocou maiores alterações morfológicas dos cristais crescidos na solução A (com Mg) (DE PAULA; SILVEIRA, 2004b). A maioria dos cristais apresentou hábito ortorrômbico além de poucos cristais geminados cíclicos. 
A glicina, a serina e o ácido glutâmico, produziram cristais sem alterações morfológicas significativas; predominaram cristais lamelares e poucos esferulitos

\section{Tabela 11 - Resultados para a cristalização do $\mathrm{CaCO}_{3}$ em presença de $\mathrm{Mg}$ e de aditivos orgânicos.}

\begin{tabular}{lll}
\hline $\begin{array}{c}\text { Aditivos } \\
\left(\mathbf{0 , 1} \text { mg.mL }^{\mathbf{1}}\right)\end{array}$ & \multicolumn{1}{c}{ Raios-X } & Infravermelho \\
\hline Asp & $99,09 \%$ aragonita & aragonita \\
& $0,91 \%$ calcita & \\
Glu & $96,2 \%$ aragonita & aragonita \\
& $3,8 \%$ calcita & \\
& & \\
Gly & $98,17 \%$ aragonita & aragonita \\
& $1,83 \%$ calcita & \\
Ser & & \\
& $100 \%$ aragonita & aragonita \\
Quitina & $100 \%$ calcita & calcita \\
\hline
\end{tabular}

Solução controle A- 99,34\% de aragonita e $0,66 \%$ de calcita

Os ácidos aspártico e glutâmico, provocaram forte inibição à cristalização do $\mathrm{CaCO}_{3}$, o que deve estar associado ao fato de esses dois aminoácidos apresentarem grupo carboxílico $\mathrm{COOH}$. A interação entre as biomoléculas e o $\mathrm{CaCO}_{3}$ ainda não é muito clara; há vários trabalhos publicados sobre as modificações morfológicas e polimórficas induzidas por agentes orgânicos na formação dos cristais biogênicos (MALKAJ; DALAS, 2004; MARIN; LUQUET, 2005; SALEUDDIN; PETIT, 1983).

Addadi e Weiner (1985), estudaram os princípios que governam a interação entre as macromoléculas orgânicas e o crescimento de cristais de $\mathrm{CaCO}_{3}$ in vitro. Fizeram vários ensaios, visando compreender o efeito do ácido aspártico na cristalização da calcita. 
Adicionaram esse aminoácido à solução de $\mathrm{CaCO}_{3}$. Como resultado, cristalizaram calcita com modificações nas faces na maioria dos ensaios (50-70\%), enquanto a ausência desse aditivo cristalizou menos que $10 \%$.

Dos aditivos orgânicos, somente a quitina afetou sensivelmente o polimorfismo dos cristais de carbonato de cálcio (solução A). A quitina é um dos materiais orgânicos mais abundantes na natureza, geralmente ligada a outros polissacarídeos e proteínas. É um polímero biodegradável e atóxico encontrado principalmente, em carapaças de moluscos, de crustáceos, no exoesqueleto de insetos e na parede celular de fungos. Possui estrutura cristalina ordenada e é insolúvel em água (ROBERTS, 1992).

A quitina utilizada neste trabalho não foi extraída das conchas de Physa devido às suas dimensões reduzidas, fator que dificulta a extração de matéria orgânica.

O espectro de infravermelho da quitina extraída do exoesqueleto de camarões e utilizada neste trabalho, está de acordo com os resultados obtidos por Brugnerotto et al. (2001). Estes autores caracterizaram detalhadamente, por espectroscopia de infravermelho, a quitina extraída de carapaças de caranguejos e de várias outras espécies. Nosso resultado, com reflexões em 9,2 e 19,3ㅜ confirmou a pureza do aditivo extraído (ROBERTS, 1992; MIKKELSEN et al., 1997) e os picos largos indicam a presença de cristalitos muito pequenos.

Comparando-se a quantificação de fases cristalinas para os diferentes aditivos aqui empregados (Tabela 11), verifica-se que a adição de quitina acarreta uma abrupta transição de fase da aragonita para a calcita. O resultado do refinamento obtido foi satisfatório, pois todos os picos puderam ser devidamente ajustados, o que garante a inexistência de outra fase na amostra. 
A quitina possui os grupos funcionais $\mathrm{C}=\mathrm{O}$ e NH (ROBERTS, 1992; HOSODA; KATO, 2001). O íon $\mathrm{Ca}$ interage com $\mathrm{C}=\mathrm{O}$, cristalizando a calcita, com orientação preferencial (104). Manoli, Koutsopoulos e Dalas (1997), também cristalizaram calcita sob a ação de quitina, obtendo espectros de raios-X característicos desse mineral, porém seus resultados mostram picos que podem estar associados a outra fase mineral ou mesmo à quitina.

Os ácidos aspártico e glutâmico possuem grupos funcionais similares aos da quitina. Os três aditivos inibem o crescimento de cristais. Entretanto, os espectros de raios-X evidenciam o fato de que, apesar dessa similaridade, a orientação e o polimorfismo dos cristais formados sob a ação da quitina são completamente diferentes daqueles crescidos sob a ação dos ácidos aspártico e glutâmico (AJIKUMAR; LOW; VALIYAVEETTIL, 2005).

O espectro de infravermelho dos cristais formados sob ação de quitina evidencia diferenças com relação àquele obtido para a solução com magnésio. Os picos identificados são característicos da calcita (WHITE, 1974) e o pico em $1079 \mathrm{~cm}^{-1}$ pode estar relacionado à presença de carbonato de cálcio amorfo (AJIKUMAR; LAKSHMINARAYANAN; VALIYAVEETTIL, 2004).

Apesar da calcita crescida na solução de controle com magnésio apresentar característica romboédrica, sob a ação da quitina, como relatado, as faces dos cristais apresentaram-se completamente modificadas (DE PAULA; SILVEIRA, 2005b); as imagens registradas mostraram agregados cristalinos.

A morfologia dos cristais obtidos a partir da solução sem $\mathrm{Mg}$, diverge daqueles formados em presença de Mg. A população de cristais é constituída por quantidade significativa de romboedros com faces bem formadas, placas e poucos esferulitos. 
A análise quantitativa de fases indicou $79,64 \%$ de calcita e $20,36 \%$ correspondente à vaterita. A presença de esferulitos sugere que exista pequena quantidade de aragonita na amostra. É possível que essa fase ocupe menos de $0,50 \%$; caso a porcentagem fosse maior, a quantificação de fases pelo método de Rietveld teria detectado esse polimorfismo.

Os resultados para a cristalização de $\mathrm{CaCO}_{3}$ sem adição de magnésio (solução $\mathrm{B}$ ), em presença de aditivos nas concentrações de $0,1 \mathrm{mg}$ e $1 \mathrm{mg}$ por $\mathrm{mL}$ de solução, estão resumidos nas Tabelas 12 e 13 .

Em presença de ácido aspártico, ocorrem alterações morfológicas. Predominam cristais tendo características semelhantes às dos agregados existentes na região interna da Physa (Figuras 27, 28 e 29). Além destes, há poucos romboedros com faces alteradas, devido à maior concentração de aditivo.

A adição de ácido aspártico provocou alterações quantitativas nas fases; houve um crescimento na quantidade de cristais de vaterita, diminuição da calcita e certa quantidade de aragonita foi identificada. Tais resultados concordam com o espectro de infravermelho, obtido, que registrou picos para a calcita e a vaterita, além de um pico de baixa intensidade que pode ser associado à aragonita, visto que a análise quantitativa também detectou esta fase. A difração de elétrons para cristais crescidos sob maior concentração de ácido aspártico, identificou calcita e vaterita. Por espectroscopia de infravermelho confirmamos a presença de calcita, aragonita e vaterita.

Outros autores mostram que o ácido aspártico provoca severas alterações polimórficas e morfológicas nos cristais de $\mathrm{CaCO}_{3}$ (FALINI et al., 2000; ORME et al., 2001; AJIKUMAR et al., 2004). Tong et al. (2004), verificaram que a adição deste aminoácido na solução de $\mathrm{CaCO}_{3}$ provoca um forte campo elétrico, devido à carga negativa do grupo carboxila, provocando a inibição da cristalização. A presença desse aminoácido à 
razão $0,5-1 \mathrm{mg} \cdot \mathrm{mL}^{-1}$, foi suficiente para transformar calcita em vaterita, sem nenhum outro componente orgânico ou íon na solução.

O ácido glutâmico possui características semelhantes às do ácido aspártico, sendo ambos aminoácidos polares de carga negativa. Os dois são aceitadores de ligações hidrogênicas e participam de interações eletrostáticas (VILELA; BACILA; TASTALDI, 1961). Em soluções de $\mathrm{CaCO}_{3}$ ambos inibem a cristalização, provocando alterações morfológicas significativas nos cristais.

O caráter inibidor do ácido glutâmico foi aqui confirmado, o aumento de sua concentração produziu quantidade reduzida de cristais com alterações nas faces. Comparando-se os nossos resultados da difração de raios-X, com relação à solução $\mathrm{B}$, observa-se crescimento da quantidade de vaterita e redução da calcita.

O ácido glutâmico, foi aquele que cristalizou a maior quantidade de aragonita. A difração eletrônica identificou a calcita como uma das fases presentes na amostra, usandose a maior concentração desse aditivo. Os espectros de infravermelho para as duas concentrações usadas confirmaram a presença de calcita, aragonita e vaterita.

De acordo com Manoli e Dalas (2001), a adição de ácido glutâmico à solução supersaturada de $\mathrm{CaCO}_{3}$, com temperatura controlada em $25 \pm 0,1^{\circ} \mathrm{C}$ e $\mathrm{pH}=8,5$, estabiliza o polimorfismo da vaterita; a adição desse aditivo em proporções crescentes, acelera o processo de crescimento dos cristais.

Nossos resultados concordam com os de Manoli e Dalas (2001), quanto à formação da vaterita ser induzida em presença de ácido glutâmico; porém, há divergências quanto à velocidade de cristalização. Imagens feitas por MEV e MO mostram alta concentração de ácido glutâmico acarreta o retardamento do processo de cristalização. 
Tabela 12 - Resultados para a cristalização do $\mathrm{CaCO}_{3}$ sem $\mathrm{Mg}$ e com aditivos orgânicos.

\begin{tabular}{ccc}
\hline $\begin{array}{c}\text { Aditivos } \\
\left(\mathbf{0 , 1} \mathbf{~ m g . m L}^{-\mathbf{1}}\right)\end{array}$ & Raios-X & Infravermelho \\
\hline \multirow{2}{*}{ Asp } & $45,48 \%$ calcita & calcita \\
& $39,15 \%$ vaterita & vaterita* \\
& $15,37 \%$ aragonita & Aragonita* \\
& $40,13 \%$ calcita & calcita \\
Glu & $41,39 \%$ vaterita & Vaterita \\
& $18,48 \%$ aragonita & Aragonita* \\
& & \\
& $71,77 \%$ calcita & calcita \\
Gly & $21,46 \%$ vaterita & vaterita* \\
& $6,77 \%$ aragonita & Aragonita* \\
& & \\
& $63,71 \%$ calcita & calcita \\
Ser & $28,35 \%$ vaterita & vaterita* \\
& $7,94 \%$ aragonita & Aragonita* \\
& & \\
\hline *picos com baixa intensidade &
\end{tabular}

Tabela 13 - Resultados para a cristalização do $\mathrm{CaCO}_{3}$ sem $\mathrm{Mg}$ e com aditivos orgânicos.

\begin{tabular}{|c|c|c|}
\hline $\begin{array}{c}\text { Aditivos } \\
\left(1 \mathrm{mg}^{\prime} \mathrm{mL}^{-1}\right)\end{array}$ & $\begin{array}{c}\text { Raios-X (R) } \\
\text { Difração eletrônica (D) }\end{array}$ & Infravermelho \\
\hline Asp & $\begin{array}{l}\text { (D) calcita } \\
\text { (D) vaterita }\end{array}$ & $\begin{array}{c}\text { calcita } \\
\text { vaterita } \\
\text { aragonita* }\end{array}$ \\
\hline Glu & (D) calcita & $\begin{array}{c}\text { calcita } \\
\text { vaterita } \\
\text { aragonita* }\end{array}$ \\
\hline Gly & $\begin{array}{c}\text { (R) } 87,30 \% \text { calcita } \\
11,10 \% \text { vaterita } \\
1,60 \% \text { aragonita }\end{array}$ & $* *$ \\
\hline Ser & (R) $100 \%$ calcita & Calcita \\
\hline Quitina & $\begin{array}{r}\text { (R) } 90,29 \% \text { calcita } \\
9,71 \% \text { vaterita }\end{array}$ & Calcita \\
\hline
\end{tabular}


Em presença de $1 \mathrm{mg} \cdot \mathrm{mL}^{-1}$ de glicina foram cristalizadas placas porosas, com diâmetros uniformes. Esse foi o único dos aditivos utilizados, que não afetou a quantidade de cristais formados. Os resultados das difrações de raios-X mostraram um aumento na quantidade de cristais de calcita, redução de vaterita e formação de poucos cristais de aragonita sob a ação da glicina. Em concordância, a espectroscopia de infravermelho detectou os três polimorfos. Os resultados quantitativos sugerem portanto, que a glicina em alta concentração estabiliza a calcita. Essas observações divergem de Manoli et al. (2002), quanto ao efeito estabilizador deste aminoácido no crescimento de cristais de carbonato de cálcio. Esses autores concluíram que a presença de glicina estabiliza a vaterita.

Foram estabilizadas a morfologia, a dimensão e o polimorfismo dos cristais de $\mathrm{CaCO}_{3}$ crescidos sob a ação de serina. A análise realizada por espectroscopia de infravermelho e o estudo quantitativo das fases, identificou a calcita, como o único polimorfo formado, para a maior concentração de aditivo,.

De todos os aminoácidos utilizados, a serina causou as maiores alterações nos cristais de $\mathrm{CaCO}_{3}$. De acordo com imagens feitas por MEV e MO, houve significativa redução no tamanho dos cristais, que está correlacionada com a diminuição da velocidade de nucleação sob a ação deste aditivo. Na literatura consultada, não foram encontrados trabalhos a respeito da serina no processo de cristalização, mas apenas uma citação feita por Addadi e Weiner em 1985, ainda sem publicação de resultados experimentais ou teóricos. Os autores sugerem que a serina não provocaria alterações morfológicas ou polimórficas nos cristais de malonato cálcio ou de fumarato de cálcio crescidos in vitro, o que está em contradição com nossos experimentos.

Os dados experimentais obtidos sobre a cristalização in vitro demonstraram que a serina exerce importante função no processo e conseqüentemente como a serina está entre 
os quatro aminoácidos predominantes no material que estudamos, admite-se que exerça a mesma influência in vivo.

O caráter inibidor da quitina foi mais uma vez confirmado, pois os cristais formados em presença desta demonstraram severas alterações morfológicas. Albeck et al. (1993) cristalizaram in vitro, $\mathrm{CaCO}_{3} \mathrm{em}$ presença de macromoléculas orgânicas extraídas de conchas do bivalve Atrina rígida. Como resultado, cresceram cristais de calcita com faces que possuem empilhamentos de placas semelhantes àquelas obtidas em nosso experimento.

Usando espectroscopia de infravermelho constatamos a presença de calcita. Há nesse espectro, picos que estão associados à presença de quitina, o que pode ser explicado pelo fato deste polissacarídeo ser insolúvel em água; e provavelmente junto aos cristais havia resíduo de quitina.

A quantificação de fases identificou a calcita como dominante e vaterita em pequena quantidade. O difratograma não possui picos relacionados à presença de quitina, o que pode estar associado ao fato desse aditivo possuir baixa cristalinidade; isto só seria possível quantificando a fase amorfa, o que não foi realizado, uma vez que o objetivo deste trabalho foi estudar a presença de calcita, vaterita ou aragonita nas amostras. A ação da quitina in vitro geralmente está associada à predominância da calcita, porém, em organismos vivos a presença de polissacarídeos está relacionada à presença de calcita e/ou vaterita (FALINI; FERMANI, 2004).

Mikkelsen et al. (1997) investigaram a precipitação do carbonato de cálcio no exoesqueleto do camarão Pandalus borealis, durante o congelamento, sob temperaturas abaixo de $-30^{\circ} \mathrm{C}$. Esses autores verificaram que durante o congelamento, os exoesqueletos ficaram recobertos por pontos brancos, que com o passar do tempo aumentaram suas 
dimensões e acabaram recobrindo toda a carapaça; após certo período, os exoesqueletos tornaram-se transparentes. Análises por espectroscopia de infravermelho e por difração e raios-X, identificaram vaterita, calcita e certa quantidade de material amorfo, relacionado à presença de quitina. Os resultados desse trabalho sugerem que a quitina exerce função relevante no processo de cristalização do carbonato de cálcio.

A concha do Lingula ungüis é composta por cristais de apatita, que mineralizam como lâminas, cuja orientação está correlacionada com o eixo das fibras da quitina (IIJIMA; MORIWAKI, 1990).

Belcher et al. (1996), isolaram de conchas de abalone, material orgânico, constituído por quitina, que está localizada entre duas camadas de proteínas fibrosas, sendo uma delas, rica em resíduos de tirosina. Os autores estudaram in vitro, a ação de quitina sobre a cristalização da aragonita e calcita, usando diferentes metodologias

$\mathrm{Na}$ Tabela 14 resumimos os resultados das análises de polimorfismo dos cristais crescidos em presença das frações orgânicas insolúvel e solúvel, extraídas das conchas de Physa.

A correlação entre a cristalização do $\mathrm{CaCO}_{3}$ e as macromoléculas orgânicas existentes nas carapaças dos moluscos, tem sido intensamente investigada por vários autores (FALINI; WEINER; ADDADI, 2003; FALINI et al.,1996, 2000).

A matriz orgânica insolúvel é rica em glicina, alanina e quitina, esta última sendo um dos componentes mais importantes dessa fração (LOWENSTAM; WEINER, 1989). A ação isolada de cada um desses componentes já foi pesquisada (HOSODA; KATO, 2001; SUGAWARA; KATO, 2000). A influência da fração insolúvel extraída de moluscos, sobre 
o $\mathrm{CaCO}_{3}$ entretanto foi pouco investigada até o presente (KATO, 2000; ${ }^{7}$ WILBUR ; WATABE 1964 apud WILBUR, 1964, p. 264-266; DE PAULA et al., 2005).

Sob a ação da matriz orgânica insolúvel, os cristais romboédricos sofreram alterações, nas faces durante o crescimento, desenvolvendo a face (001), que pode estar correlacionada à presença do grupo funcional $\mathrm{C}=\mathrm{O}$, e de polissacarídeos identificados na fração insolúvel extraída da Physa. Simultaneamente, desenvolveram-se cristais esféricos.

\section{Tabela 14 - Resultados para a cristalização do $\mathrm{CaCO}_{3}$ sem $\mathrm{Mg}$ e com matéria orgânica extraída das conchas da Physa.}

\begin{tabular}{lll}
\hline Aditivos & Raios-X & Infravermelho \\
& & \\
\hline \multirow{2}{*}{ Matriz orgânica insolúvel } & $98,68 \%$ calcita & calcita \\
& $1,32 \%$ aragonita & \\
& & \\
Matriz orgânica solúvel & $55,35 \%$ calcita & calcita \\
& $30,23 \%$ aragonita & \\
& $14,42 \%$ vaterita & \\
& & \\
\end{tabular}

Solução controle B- 79,64\% de calcita e $20,36 \%$ de vaterita

Alguns cristais formados sob a ação da fração insolúvel, possuem faces semelhantes a "degraus". Há na literatura vários estudos sobre o desenvolvimento desse tipo de estrutura em faces cristalinas (SINKANKAS, 1967; GRATZ; HILLNER, 1993; ORME et al., 2001).

Wada (1966), verificou por microscopia de polarização, que a camada nacarada da concha da Pinctada martensii, desenvolve-se a partir de figuras espiraladas com degraus medindo 1000-5000Å de altura, exceto nas lamelas encontradas na região central da espiral,

\footnotetext{
${ }^{7}$ WILBUR, K. M.; WATABE, N. Experimental studies on calcified in mollusks and the ALGA Coocolithus huxleyi. Ann. NY. Acad. Sci,, v. 109, p. 82-182, 1963.
} 
que possui $1000 \AA$ de altura. Geralmente as espirais são circulares, mas há variações de formas de acordo com a espécie e condições fisiológicas do animal. A densidade das espirais por unidade de área; a distância entre os degraus e o número de degraus em uma espiral, são conseqüência da taxa de precipitação do $\mathrm{CaCO}_{3}$.

Recentemente, Fu et al. (2005), verificaram que cristais de calcita crescidos in vitro, em presença de diferentes frações de proteínas extraídas da concha de Haliotis rufescens, interagem em regiões específicas das faces; com o incremento do período de cristalização, surgem fissuras e "degraus" nas faces dos cristais. Esses autores, identificaram apenas a calcita por difração de raios-X, sem a quantificação de fases.

Na camada nacarada e na abertura da concha da Physa, há cristais com características similares ao empilhamento de lamelas crescidas in vitro sob a ação da fração insolúvel.

Além das severas alterações morfológicas, ocorreram modificações no polimorfismo dos cristais, com relação àqueles formados na solução de controle (sem $\mathrm{Mg}$ ). Quantificando as fases, verificou-se a predominância de calcita, com orientação preferencial (104), inibição do crescimento de cristais de vaterita e indução da aragonita. Por espectroscopia de infravermelho identificou-se apenas a calcita.

Esses resultados quantitativos estão coerentes com as análises feitas para a concentração de $1 \mathrm{mg} \cdot \mathrm{mL}^{-1}$ de quitina, adicionada à solução $\mathrm{B}$, o que pode estar relacionado ao fato de a fração insolúvel da concha de molusco possuir esse componente.

Dentre os aditivos utilizados no presente trabalho, a matriz orgânica solúvel, extraída da Physa, foi aquela que apresentou a maior influência no processo de cristalização do $\mathrm{CaCO}_{3}$, produzindo significativas alterações morfológicas e polimórficas. 
Alguns dos cristais crescidos sob ação desta fração solúvel, possuem características semelhantes àquelas vistas na região interna da Physa; grande quantidade de placas foi notada, o que coincide com os resultados para a serina. Os cristais em forma de "rosetas", são semelhantes aos crescidos sob ação de ácido aspártico, bem como a vaterita crescida por Manoli e Dalas (2000) sobre fibroína.

O espectro de raios-X apresentou picos com várias orientações, o que está correlacionado ao fato de os aditivos orgânicos induzirem cristalização anisotrópica, com morfologias diretamente determinadas por diferentes taxas de crescimento em várias direções.

Dentre os aditivos, a fração solúvel foi a mais influente para a cristalização de aragonita, o que está coerente com o fato da concha da Physa ser constituída por aragonita. Apesar de não terem sido feitos ensaios para as diferentes concentrações desse aditivo, é provável que o seu incremento favoreça a formação de aragonita.

O espectro de infravermelho, possui picos similares àqueles obtidos para a adição de $1 \mathrm{mg} \cdot \mathrm{mL}^{-1}$ de serina à solução $\mathrm{B}$, o que se explica devido a serina estar presente na matriz orgânica solúvel da Physa.

O ácido aspártico foi o único que estabilizou a dimensão dos cristais para os diferentes ensaios experimentais. A serina e glicina estabilizaram as dimensões dos cristais somente na concentração de $1 \mathrm{mg}$ por $\mathrm{mL}$ de solução B.

Nos organismos vivos, a transformação do polimorfismo do $\mathrm{CaCO}_{3}$ pode ser explicada pelo fato de a calcita ser termodinamicamente menos estável que a aragonita e muito mais estável que a vaterita. Com o passar do tempo, o polimorfo menos estável tende a se dissolver, sendo precipitado novamente como calcita. O resultado desse processo, é uma tendência à redução da quantidade de vaterita (LOWENSTAM; WEINER, 1989). 
De maneira geral, as alterações nas faces dos cristais podem ser explicadas pelo fato das proteínas e cristais possuírem estruturas que, em contato com outros elementos, podem produzir múltiplas interações, tais como inibição da velocidade de nucleação e redução de íons na rede cristalina. O oposto também pode ocorrer: íons sendo incorporados à rede cristalina, aumentam o tamanho do cristal. A adsorção de proteínas na superfície do cristal durante o crescimento também causa modificações nas faces, resultando alterações morfológicas. (ADDADI; WEINER; GEVA, 2001). 


\section{Conclusões}

Conchas de Physa sp. na fase inicial do desenvolvimento possuem o perióstraco recoberto em toda sua extensão, por unidades circulares e pacotes orgânicos, que desaparecem na fase adulta, dando lugar a linhas de crescimento.

Na fase adulta, a carapaça da Physa possui logo abaixo do perióstraco, cinco camadas calcárias, formadas por arranjos lamelares, prismáticos e pela nacre, sobre essa camada há lamelas, esferas e não prismas, como nas demais espécies de moluscos.

O organismo investigado possui em sua carapaça, várias formas cristalinas semelhantes às observadas em outras espécies de moluscos; porém em nenhum dos trabalhos consultados, foram encontrados romboedros de calcita com faces bem formadas, nem lamelas organizadas em agregados esféricos, como os existentes na região interna da $P$ hysa.

Imagens feitas por MEV evidenciaram a íntima relação entre a matriz orgânica (constituída por polissacarídeos, sulfato, fosfatos, aminoácidos) e a cristalização do $\mathrm{CaCO}_{3}$ no organismo estudado.

O conjunto de técnicas utilizadas para a caracterização quantitativa e qualitativa dos componentes inorgânicos permitiu concluir que a concha do molusco Physa é constituída por aragonita e calcita desde a fase inicial do seu desenvolvimento, quando o molusco ainda está em uma cápsula envolta por material gelatinoso.

Das investigações sobre a cristalização in vitro do $\mathrm{CaCO}_{3}$ em presença de $\mathrm{Mg}$, concluise que esse elemento é capaz de cristalizar aragonita, sem que qualquer outro componente seja adicionado à solução. A omissão do Mg produziu cristais de calcita e vaterita.

Dentre os aminoácidos selecionados como aditivos, o ácido aspártico foi o único que provocou alterações morfológicas significativas e tendência a estabilizar a dimensão dos 
cristais crescidos nas soluções contendo ou não, $\mathrm{Mg}$. O ácido glutâmico, a glicina e serina provocaram variações morfológicas apenas nos cristais formados na solução sem $\mathrm{Mg}$.

Quando adicionados à solução sem $\mathrm{Mg}$, os ácidos aspártico e glutâmico que são monoamino-di-carboxílicos, mostraram tendência a cristalizar aragonita e vaterita, enquanto a glicina e serina que são mono-carboxílicos, induziram o crescimento da calcita.

Os resultados para a serina são, aparentemente, inéditos. Esse aminoácido foi o único que provocou forte transição de fase, estabilizando $100 \%$ de calcita, com uniformidade no hábito cristalino e na dimensão dos cristais.

A quitina foi o único aditivo que estabilizou o polimorfismo dos cristais, independentemente da presença ou não de magnésio na solução de $\mathrm{CaCO}_{3}$, porém não houve estabilização morfológica, para nenhum dos dois casos.

A variedade de hábitos cristalinos produzidos na ausência de Mg e em presença das matrizes orgânicas tanto solúvel como insolúvel extraídas da Physa, pode estar correlacionada ao fato destes dois aditivos possuírem em sua constituição componentes orgânicos, alguns apresentados neste trabalho, que provocam alterações na cristalização do $\mathrm{CaCO}_{3}$.

A fração orgânica insolúvel induziu a formação de calcita, enquanto a fração solúvel, produziu calcita, aragonita e vaterita. Tais resultados estão coerentes com as investigações feitas in vitro, separadamente, para cada um dos aminoácidos selecionados e para a quitina.

A partir do conjunto de resultados obtidos, é possível concluir que os aditivos orgânicos utilizados neste trabalho, exercem função relevante no processo de cristalização de $\mathrm{CaCO}_{3}$. $\mathrm{O}$ íon carboxílico $\mathrm{COO}^{-}$, presente nos aminoácidos e na quitina, adicionado à solução de $\mathrm{CaCO}_{3}$ induz alterações na morfologia e em alguns dos casos investigados, no polimorfismo dos cristais. 
As modificações na morfologia, no polimorfismo e na orientação da nucleação induzida pelos aminoácidos in vitro, podem estar ou não relacionadas com a função das macromoléculas in vivo, mas certamente, as investigações por diferentes metodologias, a maior parte delas aplicadas neste trabalho, trazem novos dados sobre a interface molecular orgânica/inorgânica envolvida no processo de cristalização dos biominerais. É relevante salientar que a síntese dos cristais por organismos vivos, ocorre sob condições ambientais.

A compreensão dos mecanismos envolvidos na síntese dos cristais biogênicos não é trivial; apesar dos investimentos nessa área de pesquisa, ainda há muito o que investigar, para que possamos produzir materiais sintéticos com propriedades semelhantes às vistas nas conchas dos moluscos. 


\section{Referências*}

ADDADI, L.; WEINER, S. Interactions between acidic proteins and crystals: Stereochemical requeriments in biomineralization. Proc. Natl. Acad. Sci. USA, v. 82, p. 4110-4114, 1985.

Control and Design Principles in Biological Mineralization. Angew Chem Int ,v.1, p. 153-169, 1992.

ADDADI, L.; WEINER, S.; GEVA, M. On how proteins interact with crystals and their effect on crystal formation. Zeitschrift für Kardiologie, v. 90 , 2001. Supl. 3, III92-III98.

AIZENBERG, J.; HANSON, J.; KOETZLE, T.F.; WEINER, S.; ADDADI, L. Control of macromolecules distribuition within synthetic and biogenic single calcite crystals. J. Am. Chem. Soc., v. 199, p. 881-886, 1997.

AIZENBERG, J.; LAMBERT, G.; WEINER, S.; ADDADI, L. Factors involved in the formation of amorphous and crystalline calcium carbonate: a study of an ascidian skeleton. J. Am. Chem. Soc., v. 124, p. 32-39, 2002.

AJIKUMAR, P. K.; LAKSHMINARAYANAN, R.; VALIYAVEETTIL, S. Controlled deposition of thin films of calcium carbonate on natural and synthetic templates. Crys. Grow. Design, v.4, p. 331-335, 2004.

AJIKUMAR, P. K.; LOW, B. J. M.; VALIYAVEETTIL, S. Role of soluble polymers on the preparation of functional thin films of calcium carbonate. Surface \& Coatings Technology, v. 198, p. 227-230, 2005.

ALBECK, S.; AIZENBERG, J.; ADDADI, L.; WEINER, S. Interactions of various skeletal intracrystalline components with calcite crystals . J. Am. Chem. Soc., v. 115, p. 11691-11697, 1993.

* De acordo com: ASSOCIAÇÃO BRASILEIRA DE NORMAS TÉCNICAS. NBR 6023: informação e documentação: referências: elaboração. Rio de Janeiro: 2002. 
ALBECK, S.; WEINER, S.; ADDADI, L. Polysaccharides of intracrystalline glycoproteins modulate calcite crystal growth in vitro. Chem. Eur., v. 2, p. 278-285, 1996.

ARRIZON-LOPEZ, V.; BIEHLER, R.; CUMMINGS, J.; HARBAUGH, J.; Beckman 6300 high performance amino acid analyzer. In: MANT, C.T; HODGES, R.S. High performance liquid chromatography of peptides and proteins: separation, analysis and conformation. Boca Raton, Florida: CRC Press, 1991. p. 859-863.

BELCHER, A.; WU, X. H.; CHRISTENSEN, R. J.; HANSMA, P. K.; STUCKY, G. D.; MORSE, D. E. Control of crystal phase switching and orientation by soluble mollusk-shell proteins. Nature, 381, p. 56-58, 1996.

BERMAN, A.; HANSON, J.; LEISEROWITZ, L.; KOETZLE, T. F.; WEINER, S.; ADDADI, L. A control of crystal texture : a widespread strategy for adapting crystasl properties to function. Science, v. 259, p. 776-779, 1993.

BIRCHALL, J.D. The importance of the study of biominerals to materials technology. In: MANN, S. WEBB, J.; WILLIAMS, J.P. Biomineralizatrion. Chemical and Biochemical Perspectives. New York: VCH Publ., 1989. Chapter 15, p. 491-509.

BLANK, S.; ARNOLDI, M.; KHOSHNAVAZ, S.; TRECCANI, L.; KUNTZ, M.; MANN, K.; GRATHWOHL; FRITZ, M. The nacre protein perlucin nucleates growth of calcium carbonate crystals. J. o f Microscopy, v. 212, p. 280-291, 2003.

BOSKEY, A. L. Mineral analysis provides insights into the mechanism of biomineralization. Calc. Tiss. Int., v. 72, p. 533-536, 2003.

BOUligAnD, Y. The renewal of ideas about biomineralizations. C. R. Palevol., v.3, p. 617-628, 2004.

BRUGNEROTTO, J.; LIZARDI, J.; GOYCOOLEA, F. M.; ARGÜLLES-MONAL, W.; DESBRIÈRES, J. An infrared investigation in relation with chitin and chitosan characterization. Polymer, v. 42, p. 3569-3580, 2001.

CALVERT, P. Biomimetic mineralization: process and prospects. Materials Science and Engineering, C1, p. 69-74, 1994. 
CARTER, J. G. Guide to bivalve shell microstructures. In: RHOADS, D. C.; LUTZ, R. A. Skeletal growth of aquatic organisms. NY and London: Plenium Press, 1980. p. 645-673.

CHATEIGNER, D.; HEDEGAARD, C.; WENK, H. R. Mollusc shell microstructures and crystallographic textures. J. Struc. Geology, v. 22, p.1723-1735, 2000.

CHECA, A. A new model for periostracum and shell formation in Unionidae (Bivalva, Mollusca). Tissue \& Cell, v. 32, p. 405-416, 2000.

CHOI, C.S.; KIM, Y.W. A study of the correlation between organic matrices and nanocomposite materials in oyster shell formation. Biomaterials, v. 21, p. 213-222, 2000.

CLARK II, G. R. Organic matrix taphonomy in some molluscan shell microsctructures. Paleogeography, Palaeoclimatology, Palaeoecology, v. 149, p. 305-312, 1999.

CRENSHAW, M. A.. The inorganic compositions of molluscan extrapallial fluid. Biol. Bull, v.143, p. 506-512, 1972.

CRUZ, R.; WEISSMÜLlER, G.; FARINA, M. Microstructure of Monoplacophora (Mollusca) Shell examined by low-voltage field emission scanning electron and atomic force microscopy. Scanning - The Journal of Scanning Microscopies, v. 25, p. 12-18, 2003.

CURREY, J. D. The mechanical behaviour of some molluscan hard tisues. J. Zool. Lond., v. 173, p. 395-406, 1974.

DANA, J. D. Manual de Mineralogia. Tradução Cornelius S. Hurlbut Junior. Rio de Janeiro: LTC, 1960. p. 355-379.

DAUPHIN, Y. Soluble organic matrices of the calcitic prismatic shell layers of two Pteiormorphid bivalves. J. of Biological Chemistry, v. 278, p.15168-15177, 2003.

Comparative studies of skeletal soluble matrices from some scleractinian corals and mollusks. Inter. J. of Biolog. Macromolecules, v. 28, p. 293-304, 2001. 
DAUPHIN, Y.; DENIS, A. Structure and composition of the aragonite crossed lamellar layers in six species of Bivalvia and Gastopoda. Comparative Biochemistry and Physiology, part A, v.126, p. 367-377, 2000.

DAUPHIN, Y.; GUZMAN, N.; DENIS, A.; CUIF, J-P.; ORTLIEB, L. Microstructure , nanostructure and composition of the shell of Concholepas concholepas (Gstropoda, Muricidae). Aquatic Living Resources, v.16, p. 95-103, 2003.

DE PAULA, S. M. Preparando padrões para determinação de tamanho de cristalito e microdeformação. Disponível em: <Labcacc.iq.unesp.br/jornal/3edicao/Divulgação.htm>. Instituto de Química da UNESP, Araraquara, 2005.

DE PAUlA, S. M.; ALEXIOU, A. D. P.; TOMA, H. E.; SILVEIRA, M. Calcium carbonate growth in presence of a biological organic additive. Brazilian Journal of Morphological Sciences, p. 70-71, 2005. Supplement 2005. Congresso da Sociedade Brasileira de Microscopia e Microanálise, 20, 2005 apresentado em Águas de Lindóia.

DE PAULA, S. M.; SILVEIRA, M. Calcium carbonate polymorphism in shells of the mollusk Physa sp. Developments in Science and Technology - Applied Mineralogy, v.1, p. 183-186, 2004a. International Council for Applied Mineralogy do Brasil, ICAM-BR, 2004 apresentado em Águas de Lindóia.

Correlation between mollusc shell length and calcium carbonate polymorphism. Acta Microscopica, v. 12, p. 7-8, 2003. Supplement B. XIX congress of the Brazilian Society for Microscopy and Microanalysis, 2003 apresentado em Caxambu.

Growth of calcium carbonate in the presence of aspartic acid. In: Brazilian Meeting on Inorganic Chemistry, 12. Joint Brazilian/Italian Meeting on Inorganic Chemistry, 2, 2004b, São Carlos. Instituto de Química de Sâo Carlos, 2004. p. 116.

Microstructural characterization of Shell components in the mollusc Physa sp. Scanning - The Journal of Scanning Microscopies, v. 27, p.120-125, 2005a.

. Growth of Calcium Carbonate in the Presence of Chitin Extracted from Shrimp. In: French-Brazilian Meeting on Polymers , 1, 2005b, Florianópolis. 1 CD-ROM. 
DEER, W.A; HOWIE, R. A.; ZUSSMAN, J. Minerais, Constituintes das Rochas: Uma introdução. Tradução Luís E. Nabais Conde . Lisboa: Calouste Gulbenkian, 1981. p. 494530.

DIMASI, E.; SARIKAYA, M. Synchrotron x-ray microbeam diffraction from abalone shell. J. Mat. Res., v. 19, p. 1471-1476, 2004.

VON DREELE, R.B; LARSON, A.C. - General Structure Analysis System (GSAS)- Los Alamos National Laboratory Report - p.86-748 (2000)

FALINI, G.; FERMANI, S.; RIPAMONTI, A. Crystallization of calcium carbonate salts into beta-chitin scaffold. J. Inorg. Biochem., v. 91, p. 475-480, 2002.

FALINI, G.; ALBECK, S.; WEINER, S.; ADDADI, L. Control of aragonite or calcite polymorphism by mollusk shell macromolecules. Science, v. 271, p. 67-69, 1996.

FALINI, G.; FERMANI, S. Review: Chitin mineralization. Tissue Engineering, v. 10, number 1/2, 2004.

FALINI, G.; FERMANI, S.; GAZZANO, M.; RIPAMONTI, A. Polymorph and architectural crystal assembly of calcium carbonate in biologically inspired polymeric matrices. J. Chem. Soc. Dalton Trans., p. 3983-3987, 2000.

FALINI, G.; WEINER, S.; ADDADI, L. Chitin-silk fibroin interactions: relevance to calcium carbonate formation in invertebrates. Calc. Tissue. Int., v. 72, p. 548-554, 2003.

FENG, Q.L.; PU, G.; PEI, Y.; CUI, F.Z.; LI, H.D.; KIM, T.N. Polymorph and morphology of calcium carbonate crystals induced by proteins extracted from mollusk shell. J. Crystal Growth, v. 216, p. 459, 465, 2000.

FRITZ, M.; BELCHER, A.; RADMACHER, M.; WALTERS, D. A.; HANSMA, P. K.; STUCKY, G. D.; MORSE, D. E.; MANN, S. Flat pearls from biofabrication of organized composites on inorganic substrates. Nature, v. 371, p. 49-51, 1994. 
FU, G.; VAIYAVEETTIL, S.; WOPENKA, B.; MORSE, D. E. $\mathrm{CaCO}_{3}$ biomineralization: acidic 8-kda proteins isolated from aragonitic abalone shell nacre can specifically modify calcite crystal morphology. Bioacromolecules, v. 6, p. 1289-1298, 2005.

GRATZ, A.; HILLNER, P. Poisoning of calcite growth viewed in the atomic force microscope (AFM). J. Crystal Growth, v. 129, p. 789-793, 1993.

GRÉGOIRE, CH. Sur la strucuture des matrices organiques des coquilles de mollusques. Biol. Rev. , v. 42, p. 653-687, 1967.

HALL, S.R.; TAYLOR, P.D.; DAVIS, S.A.; MANN, S. Electron diffraction studies of the calcareous skeletons of bryozoans. J. Inorg. Biochem., v. 88, p. 410-419, 2002.

HAN, Y-J.; AIZENBERG, J. Effect of magnesium on oriented growth of calcite on carboxylic acid functionalized self-assembled monolayer. J. Am. Chem. Soc., v. 125, p. 4032-4033, 2003.

HARE, P.E. Amino acids in the proteins from aragonite and calcite in the shells of Mytilus californianus. Science, v. 139, p. 216-217, 1963.

HASSE, B.; EHRENBERG, H.; MARXEN, J.; BECKER, W.; EPPLE, M. Calcium carbonate modifications in the mineralized shell of the freshwater snail Biomphalaria glabrata. Chem. Eur., v. 20, p. 3679-3685, 2000.

HASSE, B.; MARXEN, J.C.; BECKER, W.; EHRENBERG H.; EPPLE, M. A crystallographic study of the love dart (Gypsobelum) of the land snail Helix pomatia (L.). J. Moo. Stud. , v. 68, p. 249-254, 2002.

HOSODA, N.; KATO, T. Thin-film formation of calcium carbonate crystals: effects of functional groups of matrix polymers. Chem. Mat., v. 13, p. 688-693, 2001.

IIJIMA, M.; MORIWAKI, M. Orientation of apatite and organic matrix Lingula unguis. Calc. Tissue Int., v. 47, p. 47-237, 1990.

JOLLY, C.; BERLAND, S.; MILET, C.; BORZEIX, S.; LOPEZ, E.; DOUMENC, D. Zonal localization of shell matrix proteins in mantle of Haliotis turbeculata (Mollusca, Gastropoda). Mar. Biotechnol., v. 6, p. 541-551, 2004. 
JONES, G. M. ; SALEUDDIN, S. M. Cellular mechanisms of periostracum formation in Physa spp. (Mollusca: Pulmonata). Can. J. Zool., v. 56, p. 2299-2311, 1978.

KANAKIS, J.; DALAS, E. The crystallization of vaterite on fibrin. J. of Crystal Growth, v. 219, p. 277-282, 2000.

KAPLAN, D. Mollusc shell structures : novel design strategies for synthetic materials. Current Opinion in Colloid \& Interface Science, v.3, p. 232-236, 1998.

KATO, T. Polymer/calcium carbonate layered thin-film composites. Adv. Mater., v. 12, p. 1543-1546, 2000.

LI, X.; CHANG, W-C.; CHAO, Y. J.; WANG, R.; CHANG, M. Nanoscale structural and mechanical characterization of a natural nanocomposite material: the shell of Red Abalone. Nano letters, v. 4, p. 613-617, 2004.

LIN, A.; MEYERS, M. A. Growth and structure in abalone shell. Materials Science \& Engineering A, v. 390, p. 27-41, 2005.

LOWENSTAM, H. A. Minerals formed by organisms. Science, v. 211, p. 1226-1131, 1981.

LOWENSTAM, H. A.; WEINER, S. Mollusca. In: On Bimineralization. Oxford University Press, Inc, 1989. Chapter 6, p. 88-110.

LUTTS, A.; GRANDJEAN, J.; GRÉGORIE, C. H. X-Ray diffraction patterns from the prisms of mollusk. Archives Internationals of Physiologie et de Biochimie, v. 68, p. 829-831, 1960.

MAI, K.; ZHANG, W.; TAN, B.; HE, G. Effects of dietary zinc on the shell biominerallization in abalone Haliotis discus hannai Ino. Journal of Experimental Marine Biology and Ecology, v. 283, p. 51-62, 2003.

MALKAJ, P.; DALAS, E. Calcium carbonate crystallization in the presence of aspartic acid. Crystal Growth \& Design, v. 4, p. 721-723, 2004. 
MANN, S. Biomineralization and biomimetic materials chemistry. In: MANN, S. Biomometics Materials Chemistry. New York: VCH Printer, 1989. Chapter 1, p. 1-40.

MANN, S. Molecular recognition in biomineralization. Nature, v. 332, p. 119-124, 1988.

MANN, S. Molecular tectonics in biomineralization and biomimetic materials chemistry. Nature, v. 365, p. 499-505, 1993.

MANOLI, F.; DALAS, E. Calcium carbonate crystallization in the presence of glutamic acid. Journal of Crystal Growth, v. 222, p. 293-297, 2001.

MANOLI, F.; DALAS, E. Spontaneous precipitation of calcium carbonate in the presence of chondroitin sulfate. Journal of Crystal Growth, v. 217, p. 416-421, 2000.

MANOLI, F.; KANAKIS, J.; MALKAJ, P.; DALAS, E. The effect of aminoacids on the crystal growth of calcium carbonate. Journal of Crystal Growth, v. 236, p. 363-370, 2002.

MANOLI, F.; KOUTSOPOULOS, S.; DALAS, E. Crystallization of calcite on chitin. Journal of Crystal Growth, v. 182, p. 116-124, 1997.

MARIN, F.; LUQUET, G. Molluscan biomineralization: The proteinaceous shell constituents of Pinna nobilis L. Materials Science \& Engineering, C25, p.105-111, 2005).

MARIN, F.; LUQUET, G. Molluscan shell proteins. Comptes Rendus Palevol, v. 3, p. 469-492, 2004.

MARXEN, J.C.; BECKER, W. The organic shell matrix of the freshwater snail Biomphalaria glabrata. Comp. Biochem. Physiol. , v. 118B, p. 23-33, 1997.

MATSUSHIRO, A.; MIYASHITA, T.; MIYAMOTO, H.; MORIMOTO, K.; TONOMURA, B. ; TANAKA, A.; SATO, K. Presence of protein complex is prerequisite for aragonite crystallization in the nacreous layer. Marine Biotechnology, v. 5, p. 37-44, 2003. 
MEENAKSHI, V. R.; HARE, P.E.; WATABE, N.; WILBUR, K.M. The chemical composition of the periostracum of molluscan shell. Comp. Biochem. Physiol., v. 29, p. 611-620, 1969.

MELDRUM, F.C. Calcium carbonate in biomineralization and biomimetic chemistry. International Materials , v. 48, p. 187-224, 2003.

MELDRUM, F.C; HYDE, S. T. Morphological influence of magnesium and organic additives on the precipitation of calcite. Journal of Crystal Growth, v. 231, p. 544-558, 2001.

MEYER, H.J. The influence of impurities on the growth rate of calcite. Journal of Crystal Growth, v. 66, p. 639-646, 1984.

MIKKELSEN, A.; ENGELSEN, S. B.; HANSEN, H. C. B.; LARSEN, O.; SKIBSTED, L. H. Calcium carbonate crystallization in the $\alpha$-chitin matrix of thje shell of pink shrimp, Pandalus borealis, during frozen storage. Journal of Crystal Growth, v. 177, p. 125134, 1997.

MUTVEI, H. The nacreous layer in molluscan shells. In: OMORI M \& N. WATABE. Mechanisms of Biomineralization in Animals and Plants. The. Tokai Univ. Press, 1980, p. 49-56.

. Ultrastructural characteristics of the nacre in some gastropos. Zoologica Scripta, v. 7, p. 287-296, 1978.

NAKA, K.; CHUJO, Y. Control of crystal nucleation and growth of calcium carbonate by synthetic substrates. Chem. Mater., v. 13, p. 3245-3259, 2001.

ORME, G. A.; NOY, A.; WIERZHICKI; MCBRIDE, M. T.; GRANTHAM, M.; TENG, H. H.; DOVE, P. M.; DEYOREO, J. J. Formation of chiral morphologies through selective binding of amino acids to calcite surface steps. Nature, V. 411, P. 775-779, 2001.

PERCOT, A.; VITON, C.; DOMARD, A. Optimization of chtin extraction from shrimp shells. Biomacromolecules, v. 4, p. 12-18, 2003. 
PEREIRA-MOURIÉS, L.; ALMEIDA, M.J.; RIBEIRO, C.; PEDUZZI; BARTHÉLEMY, M.; MILET, C.; LOPEZ, E. Soluble silk-like organic matrix in the nacreous layer of the bivalve Pinctada maxima. Eur. J. Biochem., v. 269, p. 4994-5003, 2002.

POKROY, B.; QUINTANA, J. P. ; CASPI, E. N.; BERNER, A.; ZOLOTOYABKO, E. Anisotropic lattice distorcions in biogenic aragonite. Nature Materials, v. 3, p. 900-902, 2004.

REDDY, M.M.; WANG, K.K Crystalyzation of calcium carbonate in the presence of metal ions. J. of. Cryst. Grow., v. 50, p. 470-480, 1980.

ROBERTS, G. A. F. Preparation of chitin and chitosan. In: London: The Macmillan Press LTD, 1992. Chapter 2, p. 54-83. Chitin Chemistry.

ROUSSEAU, M.; LOPEZ, E.; COUTÉ, A.; MASCAREL, G.; SMITH, D.; NASLAIN, R.; BOURRAT, X. Sheet nacre growth mechanism : a Voronoi model. J. of Structural Biology, v. 149, p. 149-157, 2005.

ROUSSEAU, M.; LOPEZ, E.; STEMPFLÉ, P.; BRENDLÉ, M.; FRANKE, L.; GUETTE, A.; NASLAIN, R.; BOURRAT, X. Multiscale structure of sheet nacre. Biomaterials, v. 26, p. 6254-6262, 2005.

SALEUDDIN, A. S. M. Fine structure of normal and regenerated shell of Helix. Can. J. Zool., v. 49, p. 37-45, 1971.

SALEUDDIN, A. S. M.; PETIT, H. P. In: SALEUDDIN, A. S. M.; WILBUR, K. M. The Mollusca Vol. 4, Part 1, Physiology. London: Academic Press Inc, 1983. Chapter 5, p. 199-233.

SIMKISS, K.; WILBUR, K. M. Mollusc- Epithelial Control of Matrix and Minerals. In: Biomineralization: Cell Biology and Mineral Deposition. San Diego: Academic Press, 1989. Chapter 14, p. 230-259.

SINKANKAS, J. Crystal Growth. In: SINKANKAS, J. Mineralogy : A fisrt course. Second Edition. London: D. Van Nostrand Company, INC., 1967. Cap. 4, p. 57-68. 
SOETE, D.; GIJBLES, R.; HOSTE, J. Survey of Neutron Activation Analysis. In; Survey of Neutron Activation Analysis. London: Wiley Interscience, 1972. Chapter 12: p. $565-736$.

SUDO S.; FUJIKAWA, T.; NAGAKURA, T.; OHKUBO, T.; SAKAGUCHI, K.; TANAKA, M.; NAKASHIMA, K. Structure of mollusk shell framework proteins. Nature, v. 387, p. 563-564, 1997.

SUGAWARA, A.; KATO, T. Aragonite $\mathrm{CaCO}_{3}$ thin-film formation by cooperation of $\mathrm{Mg}^{2+}$ and organic polymer matrices. Chem. Comm., p. 487-488, 2000.

SUMMER, A.T.; SUMMER, B.E.H. Procedures for non-vital observations. In: A

Laboratory Manual of Microtechnique and Histochemistry. Oxford and Edinburgh: Blackwell Scientific publications, 1969, p. 62-64.

TAYLOR, J.D.; KENEDY, W.J. The influence of the periostracum on shell structure of bivalve mollusks. Calc. Tissue. Res., v. 3, p. 279-283, 1969.

TEVESZ, M.J.S.; CARTER, J.G. In: RHOADS, D.C.; LUTZ, R.A. Skeletal Growth of Aquatic Organisms- Biological Records of Environmental Change. London and New York: Plenum Press. Chapetr 8, 1980, p. 295-322.

THOMPSON, J. B.; PALOCZI, G.; KIMDT, J. H.; MICHENFELDER, M.; SMITH, B. L.; STUCKY, G.; MORSE, D. E.; HANSMA, P. K. Direct observation of the transition from calcie to aragonite growth as induced by abalone shell proteins. Biophysical Journal, v. 79, p. 3307-3312, 2000.

TOBY, B.H. EXPGUI, a graphical user interface for GSAS. J. Appl. Cryst., v. 34, p. 210$221,2001$.

TONG, H.; HU, J.; MA, W.; ZHONG, G.; YAO, S.; CAO, N. In Situ analysis of the organic framework in the prismatic layer of mollusk shell. Biomaterials, v. 23, p. 25932598, 2002.

TONG, H.; MA, W.; WANG, L.; WAN, P.; HU, J.; CAO, L. Control over the crystal phase, shape, size and aggregation of calcium carbonate via a L-aspartic acid inducing process. Biomaterials, v. 25, p. 3923-3929, 2004. 
TSUJII, T. Mineral deposition in mollusks shells . In: OMORI, M.; WATABE, N. The mechanisms of biomineralization in animals and plants. Tokai: Univ. Press., 1980, p. 57-65.

VILELA, G. G.; BACILA, M.; TASTALDI, H.. Aminoácidos- Polipeptídeos e Proteínas. In: . Bioquímica. Rio de Janeiro: Guanabara, 1961. Capítulo 8, p. 127-162.

VON DREELE, R.B; LARSON, A.C. GSAS Software. LANSCE, MS-H805. Los Alamos National Laboratory. Copyright 1985-2000. The regents of the Univesity of California, 2001.

WADA, K. Spiral Growth of nacre. Nature, v. 24, p. 1427, 1966.

WANG, J.; XU, Y.; ZHAO, Y.; HUANG, Y.; WANG, D.; JIANG, L.; WU, J.; XU, D. Morphology and crystalline characterization of abalone shell and mimetic mineralization. Journal of Crystal Growth, v. 252, p. 367-371, 2003.

WATABE, N. Decalcification of thin sections for electron microscope studies of crystalmatrix relationships in mollusk shells. The J. of Cell Biology, v. r8, p. 701-703, 1963.

Crystal growth of calcium carbonate in the invertebrates. Prog. Cryst. Growth Charact., v. 4, p. 99-147, 1981. 1960. . Influence of the organic matrix on crystal type in mollusks. Nature, v. 22, p. 188, Shell. In: BEREITER-HAHN, J.; MATOLTSY, A.G.; RICHARDS, S. Biology of the Integument, 1 invertebrates. Springer-Verlag, Berlin, Heidelberg, NY, Tokyo, 1984. Chapter 25, p. 448-485.

Studies on shell formation: Crystal-matrix relationships in the inner layers of mollusks shells. J. Ultrastructure Research , v.12, p. 351-370, 1965.

WEINER, S. Mollusk shell formation; isolation of two organic matrix proteins associated with calcite deposition in the bivalve Mytilus californianus. Biochemistry, v. 22, p. 41394145, 1983. 
WEINER, S. Aspartic acid-rich proteins: major components of the soluble organic matrix of mollusk shells. Calcified Tissue International, v. 29, p. 163-167, 1979.

WEINER, S.; ADDADI, L. Design strategies in mineralized biological materials. J. Mat. Chem., v.7, p. 689-702, 1997.

WEINER, S.; HOOD, L. Soluble protein of the organic matrix of mollusk shells; a potential template for shell formation. Science, v. 190, p. 987-989, 1975.

WHEELER, A.P.; GEORGE, J.W..; EVANS, C.A. Control of calcium carbonate and crystal growth by soluble matrix of oyster. Science, v. 212, p.1397-1398, 1981.

WHITE, W. B. The carbonate minerals. In:___ Infrared Spectra of Minerals. Mineralogical Society of London, Monograph, n.4, 1974. p. 227-284.

WILBUR, K. M. Shell formation and regeneration. In: WILBUR, K.M.; YONGE, C. M. Physiology of Mollusca. New York and London: Academic Press, 1964. Chapter 8, 243282.

WILBUR, K.M.; SALEUDDIN, A.S.M. Shell Formation. In: SALEUDDIN, A. S. M.; WILBUR, K. M. The Mollusca Vol. 4, Part 1, Physiology. London: Academic Press Inc, 1983. Chapter 6, p. 1235-287.

WILT, F.H.; KILLIAN, C.E.; LIVINGSTON, B.T. Development of calcareous skeletal elements in invertebrates. Differentiation, v. 71, p. 237-250, 2003.

XIE, A-J.; YUAN, Z-W; SHEN, Y-H. Biomimetic morphogenesis of calcium carbonate in the presence of a new amino-carboxl-chelating-agent. Journal of Crystal Growth., v. 276, p. 265-274, 2005.

YANG, L.; ZHANG, X.; LIAO, Z., GUO, Y.; HU, Z.; CAO, Y. Interfacial molecular recognition between polysaccharides and calcium carbonate during crystallization. Inorganic Biochemistry, v. 97, p. 377-383, 2003.

YIN, Y.; HUANG, J.; PAINE, M. L.; REINHOLD, V. N.; CHASTEEN, N. D. Structural characterization of the major extrapalial fluid protein of the mollusk Mytillus edulis: Implications for function. Biochemistry, v. 44, p. 10720-10731, 2005. 
ZOLOTOYABKO, E.; QUINTANA, J. P. Non destructive microstructural analysis with depth resolution : applications to sea shells. Appl. Cryst., v. 35, p. 594-599, 2002. 


\section{Apêndice A}

Publicações e comunicações em congressos:

1 - DE PAULA, S. M.; SILVEIRA, M. Microstructural characterization of shell components in the mollusc Physa sp. Scanning - The Journal of Scanning Microscopies, v. 27, p.120-125, 2005a

$2-$ Growth of Calcium Carbonate in the Presence of Chitin Extracted from Shrimp. In: French-Brazilian Meeting on Polymers, 1, 2005b, Florianópolis. CD-ROM.

3 - DE PAUlA, S. M.; AlEXIOU, A. D. P.; TOMA, H. E.; SILVEIRA, M. Calcium carbonate growth in presence of a biological organic additive. Brazilian Journal of Morphological Sciences, p. 70-71, 2005. Supplement 2005. Congresso da Sociedade Brasileira de Microscopia e Micro-análise, 20, 2005 Águas de Lindóia.

$4-$ .Calcium carbonate polymorphism in shells of the mollusk Physa sp. Developments in Science and Technology - Applied Mineralogy, v.1, p. 183-186, 2004a. International Council for Applied Mineralogy do Brasil, ICAM-BR, 2004 apresentado em Águas de Lindóia.

$5-$ Growth of calcium carbonate in the presence of aspartic acid. In: Brazilian Meeting on Inorganic Chemistry, 12. Joint Brazilian/Italian Meeting on Inorganic Chemistry, 2, 2004b, São Carlos. Instituto de Química de São Carlos, 2004. p. 116.

6 - Correlation between mollusc shell length and calcium carbonate polymorphism. Acta Microscopica, v. 12, p. 7-8, 2003. Supplement B. XIX Congress of the Brazilian Society for Microscopy and Microanalysis, 2003 Caxambu.

7- DE PAULA, S. M.; SILVEIRA, M. Biomineralization in molluscs. In: Microscopia e Micro-análise no Mercosul - Simpósio de Metodologias Integradas ao Estudo da Biologia e Micromat, 2002 Curitiba. CD-ROM. 


\title{
Microstructural Characacterization of Shell Components in the Mollusc Physa sp.
}

\author{
Silvia M. de Paula and Marina Silveira.
}

Labroratory of Electron Microscopy, Institute of Physics, University of São Paulo, São Paulo, Brazil

Summary: Shells of the freshwater, pulmonate snail Physa (Mollusca, Gasteropoda), ranging from 0.5 to $10 \mathrm{~mm}$ in length, were studied using scanning microscopy, $x$-ray analysis, and infrared spectroscopy. Results obtained suggest that the shell is composed of aragonite, which occurs in several distinct crystalline forms. A selective distribution of crystalline forms (hexagonal plates, prisms, rhombohedra, and spherulites) occurred along specific sites of the shell. A variable distribution of the forms was also detected in adult shells and in protoconchs of developing embryos. Qualitative elemental analysis, using an energy-dispersive spectrometer, corroborates the presence of calcium, phosphorus and sulphur ions.

Key words: biomineralization, gasteropoda, $P$ hysa, calcium carbonate, microstructures, spectroscopies

PACS: $61.10-\mathrm{i}, 61.16 \mathrm{BG}, 61.66 \mathrm{Fn}, 87.64 \mathrm{Ee}, 87.68 .+\mathrm{e}$

\section{Introduction}

A number of carbonaceous biominerals, with variable structures and a range of functions are synthesized by living organisms. Previous studies have shown that they perform protective, skeletal, gravity perception and other sensorial functions (Addadi and Weiner 1992, Mann and Weiner 1999). Biomineralization is a complex process in which biological activity controls the deposition of widely diverse crystal shapes and aggregates. The biocomposites and the phenomena involved in their deposition is of interest to biologists, geologists, and materials scientists.

Mollusc shells represent an interesting model for study because at least seven distinct types of calcium carbonate

\footnotetext{
Address for reprints:

Silvia Maria de Paula

Laboratório de Microscopia Eletrônica

Instituto de Física

Universidade de São Paulo

C.Postal 66318

05315-970 São Paulo, Brasil

e-mail: sipaula@if.usp.br
}

biominerals are found. These biominerals occur in a crystalline phase as calcite or aragonite. In addition, gastropod molluscs contain vaterite, a polymorph that is rare in nature (Hasse et al. 2000, Meldrum 2003). Acidic proteins, polysaccharides, and other macromolecules are involved in inducing, orientating, and regulating the deposition of the mineral phase (Albeck et al. 1996). This organic phase constitutes a framework of macromolecules that supports, and in some way drives, epitaxial growth of the polymorphs of the carbonate during the mineralizing process (Levi-Kalisman et al. 2001, Mann 1989). However, investigators suggest that knowledge of all aspects of biomineralization could be extended to devise novel synthetic composite materials with optimized technological properties (Meldrum 2003, Stupp and Braun 1997).

In the present investigation, the shells of Physa were studied by scanning electron microscopy; the mineral phases that occurred were identified by $\mathrm{X}$-ray diffraction (XRD) and the polymorphic composition was determined by infrared spectroscopy (FTIR). Energy-dispersive spectrometer (EDS) analyses in the scanning electron microscope (SEM) provided the spatial distribution of trace elements such as phosphorus and sulphur. Results suggest that in Physa the prevailing form of calcium carbonate that makes up the shell from the early stages of embryonic development up to the adult individual is aragonite. This study indicates that calcite is also present in much lower concentrations; however, its distribution in the shell cannot be ascertained.

\section{Materials and Methods}

\section{Scanning Electron Microscopy}

Specimens of Physa sp., a freshwater snail (Mollusca, Gasteropoda), were reared in small aquaria at $26 \pm 1^{\circ} \mathrm{C}$ and nourished with lettuce and fish food. Organisms ranging in size from 0.5 to $10 \mathrm{~mm}$ were relaxed with menthol, their shells were then removed by manipulation, washed in distilled water for $24 \mathrm{~h}$, cleaned with $40 \%$ sodium hypochloride solution for $12 \mathrm{~h}$, rewashed in water, then in $97 \%$ ethanol, and allowed to dry over filter paper for $24 \mathrm{~h}$. For progressively accessing the inner layers of the shell, mild 
chemical etching was applied (in either $0.1 \mathrm{~N} \mathrm{HCl}, 10 \mathrm{~min}$, or $2 \%$ ethylenediamine tetraacetic acid [EDTA], 2 min.). Small fragments of the shell were mechanically cut with a blade to obtain transverse orientations. Samples were mounted on stubs, sputtercoated with a $32 \mathrm{~nm}$ thick gold film (Edwards S-150) (Edwards High Vacuum, W. Sussex, U.K.), and imaged in a JEOL JSM-840A SEM (JEOL Ltd., Tokyo, Japan) operated at $25 \mathrm{kV}$; these conditions favored a good conductivity for the sample, high signal/noise ratio, and adequate resolution, for the selected magnifications.

\section{Elemental Analysis}

Qualitative elemental analysis of carbon-coated fragments of shells was performed at $25 \mathrm{kV}, 15 \mathrm{~mm}$ working distance. At this potential, $\mathrm{x}$-ray emission improves.

\section{$\mathrm{X}$-ray Diffraction}

For x-ray analysis, shells that had been extensively washed in distilled water were dried at room temperature, mechanically reduced to a fine powder, passed through a 200-mesh sieve, and studied with the X-Pert MPD Philips diffractometer (Philips, Eindhoven, Holland). The data

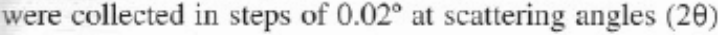
ranging from 24 to $90^{\circ}$. The XRD curves obtained were refined by the Rietveld method.

\section{Fourier Transform Infrared Spectroseopy}

Shell powders prepared as above for X-ray analysis were also embedded in $\mathrm{KBr}$ pellets for FTIR spectroscopy. Data were recorded at $4 \mathrm{~cm}^{-1}$ resolution, using a Nicolet 560 FTIR equipment (Nicolet, Madison, Wisc., USA).

\section{Results}

The shape of the gastropod shell conforms to the general pattern as it has a left-handed spiral turn (Fig. 1). At the apical pole, the first and second protoconchs present distinct growth bands; meridional striations become less defined toward the turn of the shell. At higher magnification, the surface of young shells (up to $2 \mathrm{~mm}$ ) is covered by flat, somewhat circular plates, measuring about $1.6 \mu \mathrm{m}$ in diameter, that overlap to some extent (Fig. 2). These peculiar plates are never found in older shells. Occasionally, the plates are masked by a thin homogeneous coating.

Results reveal various crystalline forms that make up the shell of Physa. The bulk of the shell consists of several organized layers; the most prominent is the porous, central layer.

Vertical fractures (Fig. 3) reveal five crystalline layers that lie beneath the periostracum. They are characterized as follows: Layer 1), formed by short, vertical prisms, about $1.5 \mu \mathrm{m}$ high, which contact the outer periostracum; Layer 2), a crossed lamellar layer parallel to the shell surface and formed by foliated crystals that have their longitudinal axes oriented at about $120^{\circ}$ (Fig. 4); Layer 3), the medium layer (ca. 25-30 $\mu \mathrm{m}$ thick) consisting of columnar rows of plates; Layer 4), crystals that are symmetrical to layer 2 and Layer 5), the innermost nacreous layer that is highly light-reflective, exhibits less organization, has irregular undulations, and covers the chamber (Fig. 5). Treatment of the shell with sodium hypochloride or with acid bath failed to reveal greater surface details. Increase in thickness accompanies elongation of the shell up to maturity at about $10 \mathrm{~mm}$. The shell opening is the site of continued crystal deposition. Organized layers of flat crystals are characteristic in this region (Fig. 6).

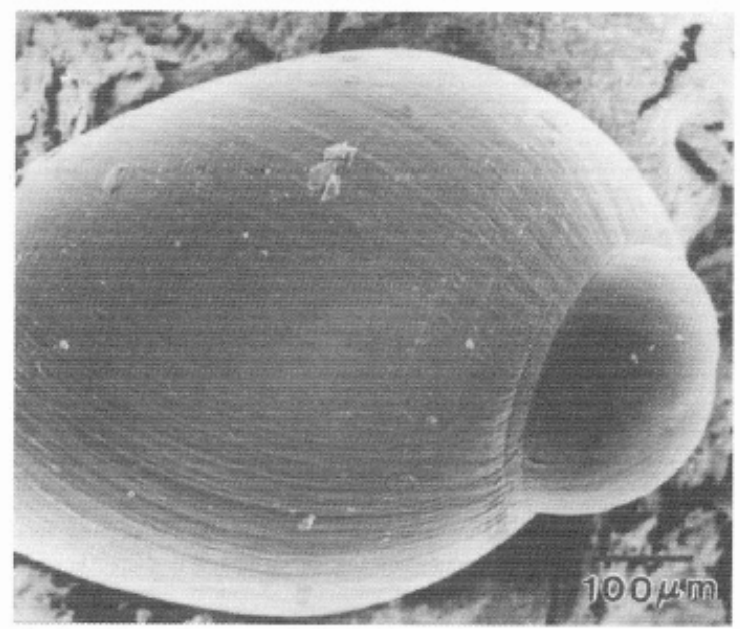

FIG. 1 View of a young shell of Physa (about $1 \mathrm{~mm}$ in length), with growth bands. $\times 110$.

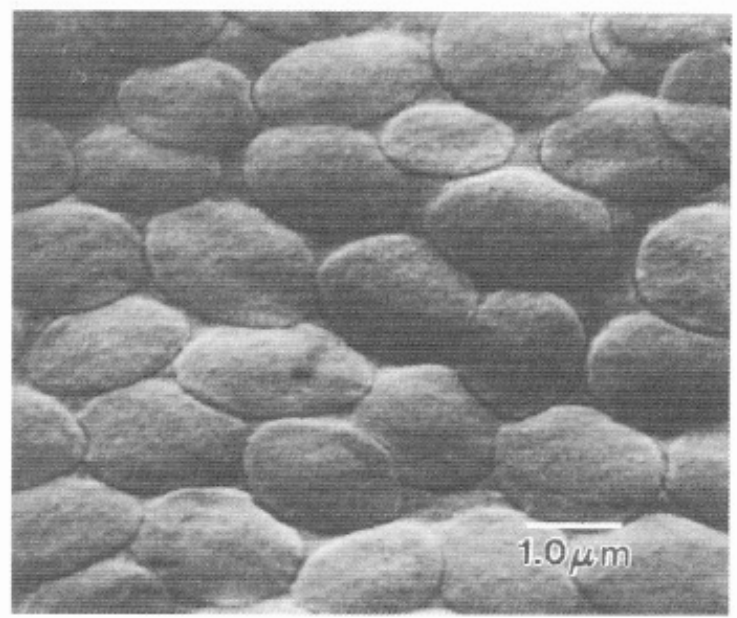

Fig. 2 Somewhat circular units on the external surface of a shell similar to that shown in Fig. 1. $\times 10,000$ 
To access the crystalline components, adult shells ranging in size from 2 to $9 \mathrm{~mm}$ were chemically etched. These preparations revealed needle-like crystals (Fig. 7); well-formed spheres, 0.5 to $1.0 \mu \mathrm{m}$ in diameter (Fig. 8); as well as cubic crystals, hexagonal plates (Figs. 9, 10), short prisms, and rhombohedra (Fig. 11). Polyhedral crystals have contact with a homogeneous layer that may represent the organic matrix (Fig. 12). These crystalline forms are more frequent along the surface of the columella of the older shells.

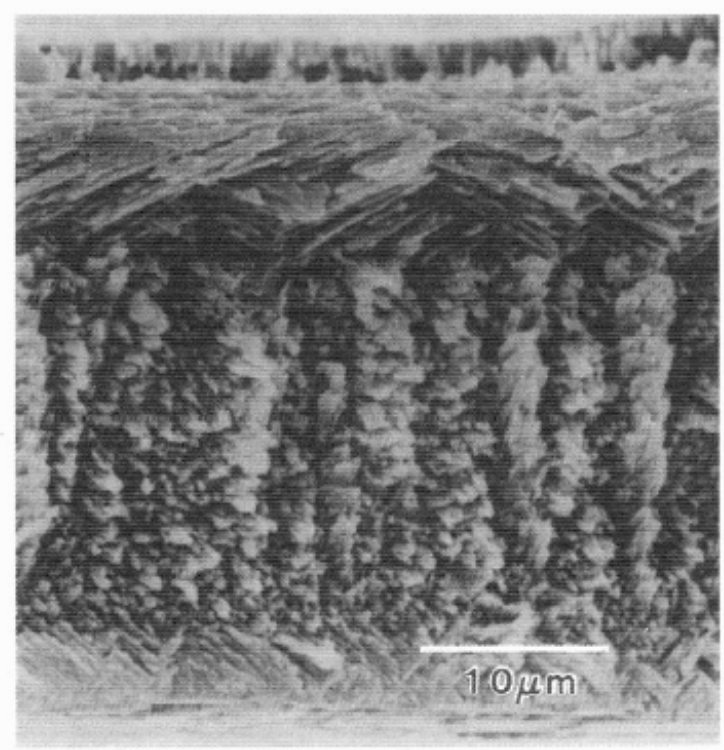

FIG. 3 Cross sectioned shell, about $4 \mathrm{~mm}$ thick, illustrating five layers. Periostracum is located on the top of Layer $1 . \times 2,100$.

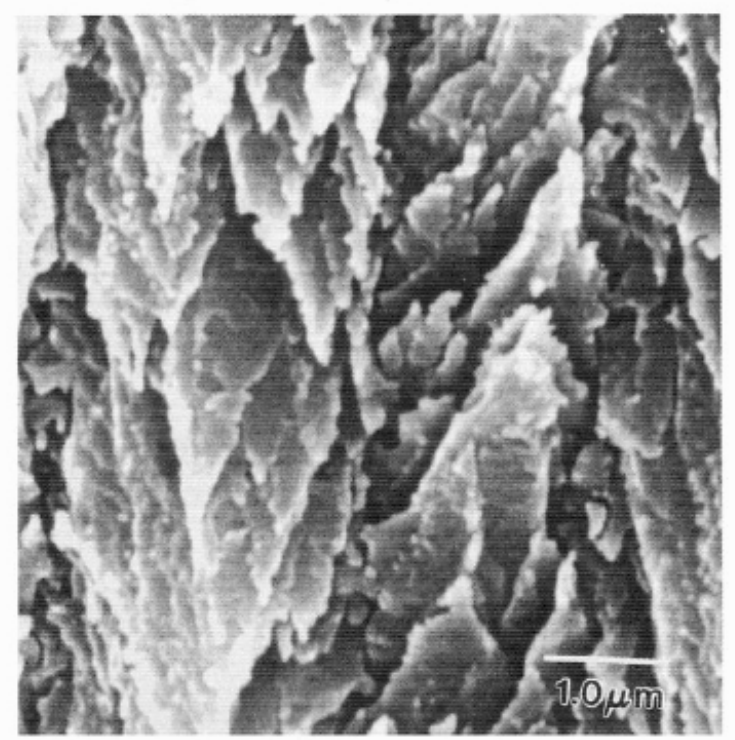

FIG. 4 Detail of Layer 2 after etching with $1 \mathrm{~mol}^{-l^{-1}} \mathrm{HCl}$ for $15 \mathrm{~s}$. $\times 13,500$.
Within the voids of Layer 3 are aggregates of acicular aragonitic crystals and well-formed spherulites, which are randomly distributed (Fig. 8). All mineral phases were analyzed by XRD The data that were refined by the Rietveld method (Fig. 13), show $99.4 \%$ aragonite and just $0.6 \%$ calcite. Analysis $\left(\mathrm{x}^{2}=1.53\right)$ was a good indicator for refinement. Accordingly, Fig. 14 shows the corresponding FTIR spectrum of the $\mathrm{CaCO}_{3}$ crystals with absorption peaks at $860 \mathrm{~cm}^{-1}$ and $713 \mathrm{~cm}^{-1}$, which is characteristic of the aragonite phase (White 1974).

Figure 15 shows the corresponding EDS spectrum, which identifies calcium as the major element and confirms the carbonaceous nature of the shell. Trace amounts of sulphur and phosphorus, elements that might be attributed to a residue of the (organic) periostracum, were also detected.

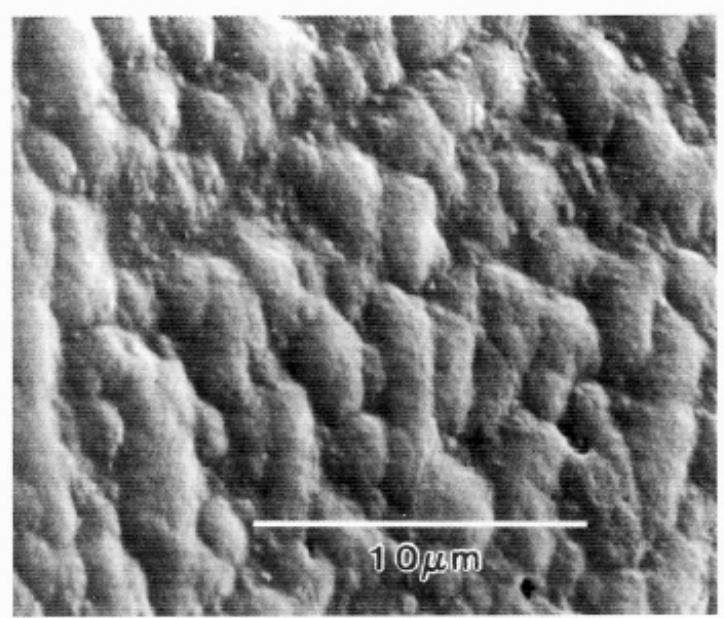

FIG. 5 Surface view of the nacreous layer that exhibits smooth undulations. $\times 3,700$.

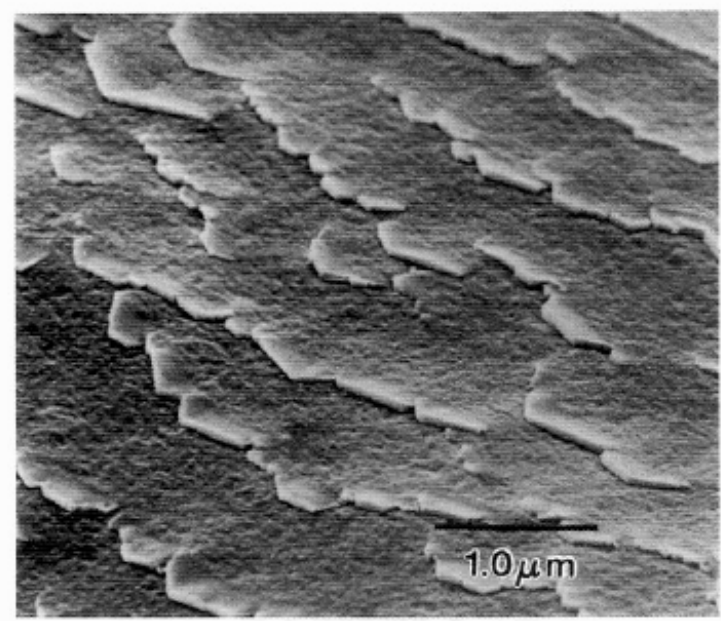

FIG. 6 Foliated aragonite crystals organized in steps along the aperture of the shell. $\times 1,800$. 


\section{Discussion}

The microstructure of the shell of Physa sp. has not been studied, except for investigations on the periostracum (Jones and Saleuddin 1978, Saleuddin and Petit 1983). The present study contributes new data on the morphology and the crystalline characterization of calcium carbonate polymorphs in a gastropod. Mollusc shells represent an example of a biomineral with desirable mechanical properties, such as toughness, resistance to fracture, strength in tension, and stiffness (Meldrum 2003). In particular, thin aragonite crystals, combined with a delicate organic matrix such as that found in nacre, has mechanical properties that

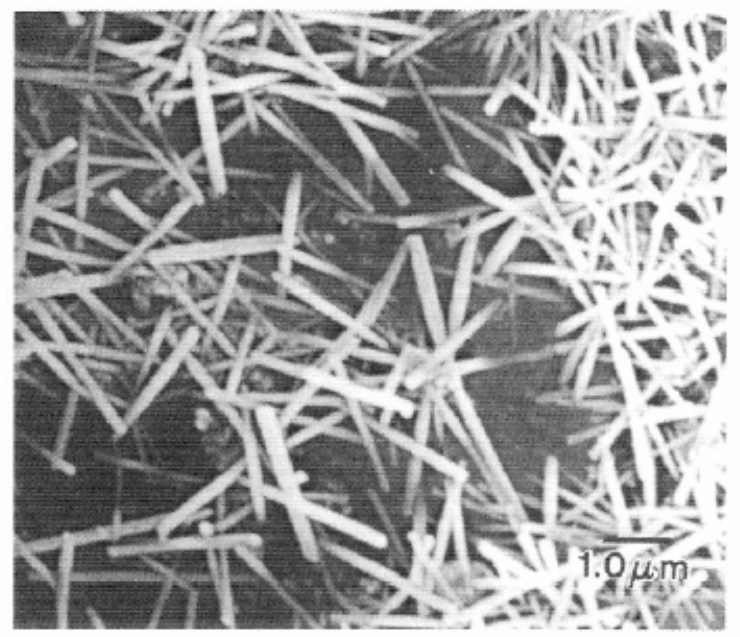

FIG. 7 Aggregate of aragonite prisms commonly found within Layer 3 of the shell following treatment in $0.1 \mathrm{~mol} \mathrm{I}^{-1} \mathrm{HCl}$ for $5 \mathrm{~min}$. $\times 7,000$.

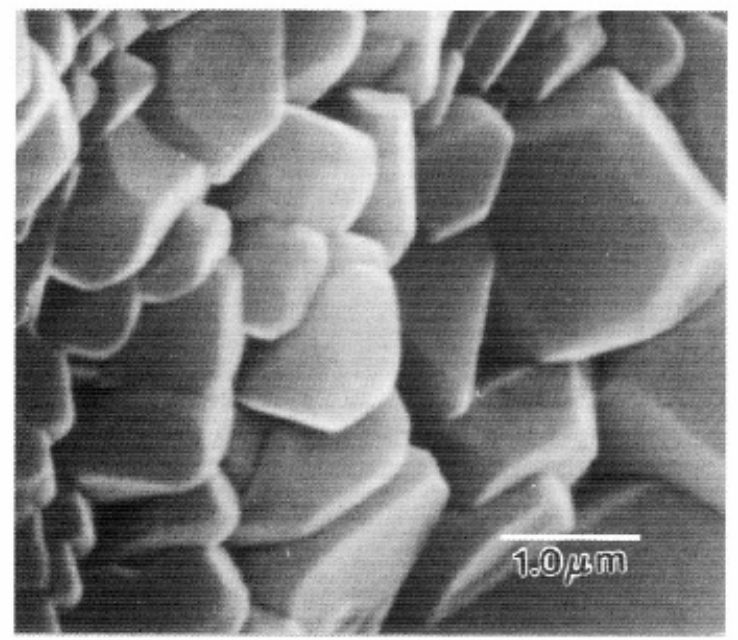

surpass polymers and concrete (Birchall 1989). In addition, calcium carbonate is water insoluble and can be delaminated to nano-sized dimensions. These properties relate to the microstructural arrangement of the crystals and their intervening organic layers (Currey and Taylor 1974).

The flat, circular units of aragonite in young shells of Physa later disappear in adults. Whether these units would shift into bulky crystals or become masked by another crystalline covering in older shells remains unknown. Fritz et al. (1994) succeeded in biofabricating similar "flat pearls" of calcite, which were later on converted into aragonite. According to Wada (see Wilbur 1964), formations present in the nacre of the oyster Pinctata indicate

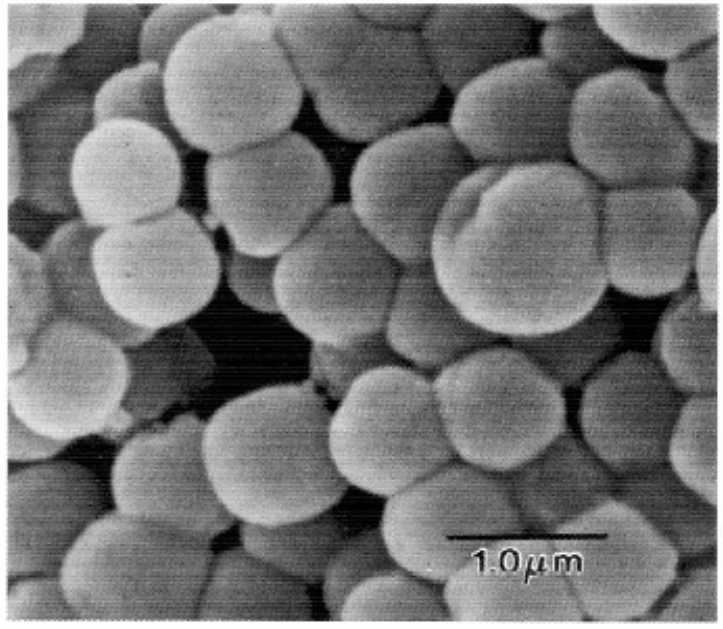

FIG. 8 Spherulitic-shaped crystals, possibly of calcite, concentrated near the apex of a shell at its inner face. $\times 18,000$.

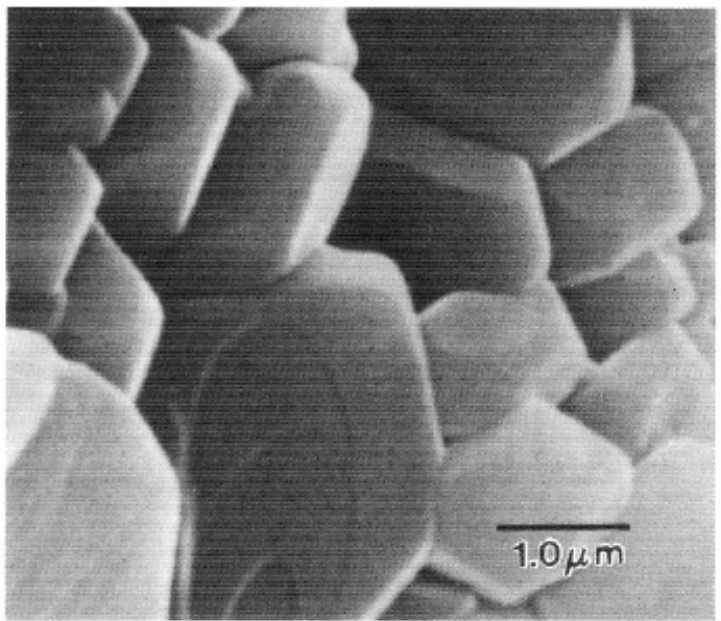

Figs. 9, 10 Plate-like and polygonal-shaped crystals that occur along the inner surface of the shell. Sample was cleaned in $\mathrm{NaOCl} 40 \%$ for 24 $\mathrm{h}$ and etched with EDTA $2 \%$ for $1 \mathrm{~min} . \times 15,000$. 
rapid growth of aragonite. However, in Physa, the circular units do not occur in the nacreous layer, but rather on the external surface of the shell.

Polymorphism of calcium carbonates in mollusc shells is related to the organic components, mainly acidic proteins and glycoproteins, present in the matrix (Hare 1963). However, many other factors are known to influence the preferred crystallization (see Addadi and Weiner 1992, Fritz et al. 1994). In gastropods, the periostracum has a mineralizing function that influences the deposition of calcium carbonate crystals of the prismatic layer (Simkiss and Wilbur 1989). The periostracum is secreted by the mantle in bivalves and gasteropoda. The mature perio- stracum of Physa consists of an external lamella and one sublamellar layer (Saleuddin and Petit 1983).

The crossed lamellar layer appears to contact the outer prismatic layer, although in some fractures, this arrangement was ambiguous. Watabe (1984), who discusses the origin of the crossed lamellar layer, suggests that it could come from spherulites that are continuous with the prismatic layer.

Finely foliated crystals arranged into parallel bands along the shell opening (see Fig. 6) also occur in the bivalve, Propeamussium dalli, and in fractured walls of the bryozoan, F. ramosa (Hall et al. 2002).

Various calcium carbonate crystalline structures occur in Physa. Well-formed plates and rhombohedral crystals,
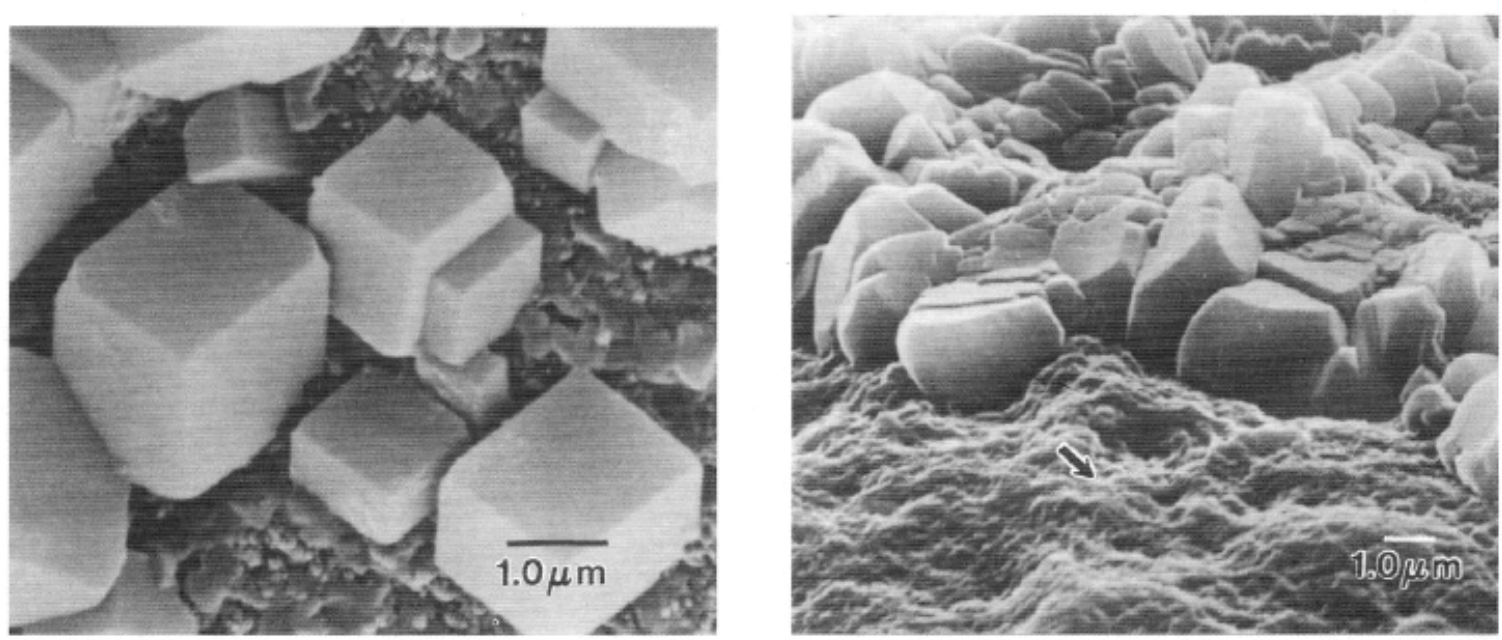

Fics. 11, 12 Well-grown rhombohedra; several are twinned (Fig. 11). Other crystalline forms of aragonite/calcite are found along the inner surface, near the apical pole of the shells. Fig. 11, treated with 1 mol..$^{-1} \mathrm{HCl}$ for $1 \mathrm{~min} . \times 11,000$; Fig. 12, cleaned in NaOCl $40 \%$ for $24 \mathrm{~h}$ and etched with EDTA $2 \%$ for 1 min. $\times 5,000$

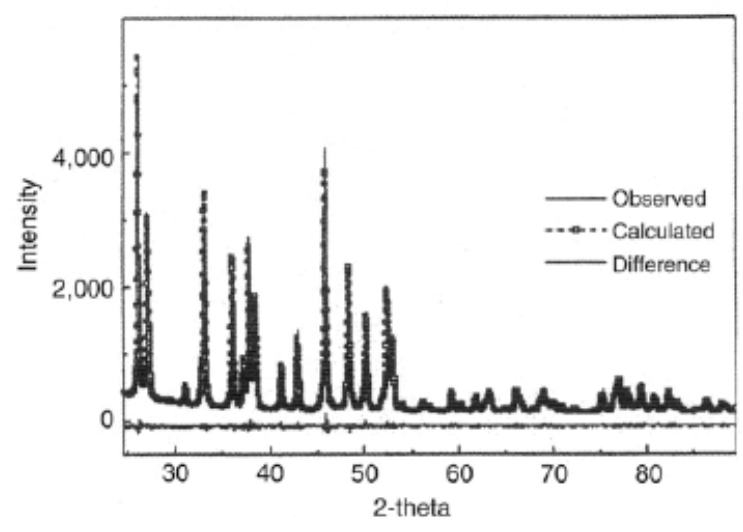

FIG. 13 Rietveld refinement of a diffraction pattern. Open squares correspond to the experimental points, the solid line to the calculated curve. Bottom line shows a difference plot (experimental minus calculated data).

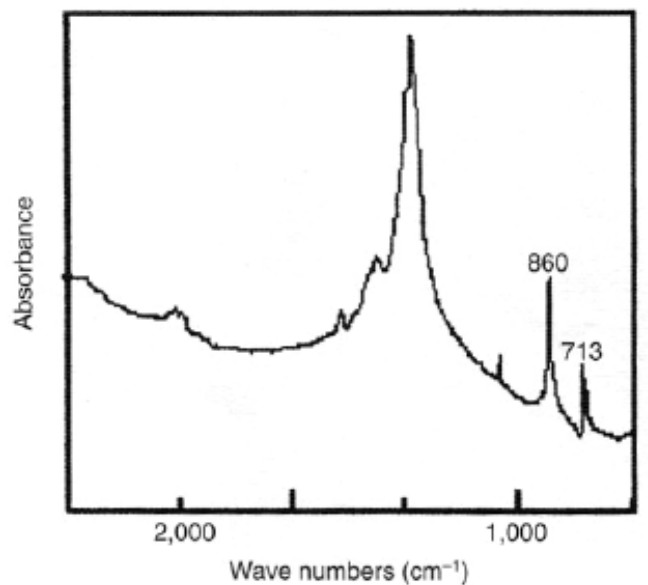

FIG. 14 Fourier transform infrared spectrum, showing peaks at 860 $\mathrm{cm}^{-1}$ and $713 \mathrm{~cm}^{-1}$, which are characteristic for aragonite. 


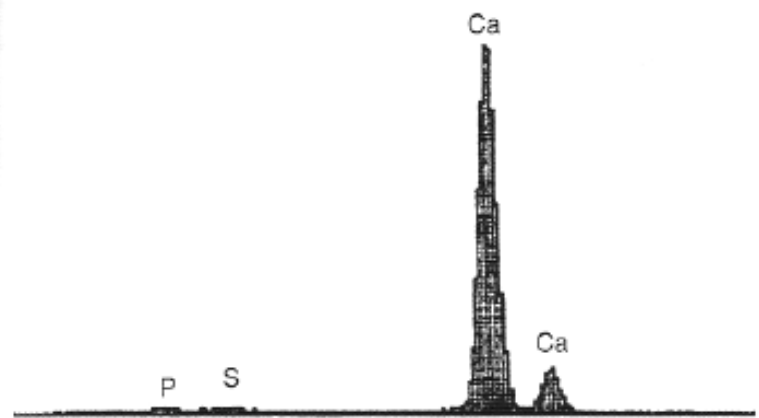

FTG. 15 Energy-dispsersive spectroscopy spectrum of a shell showing high concentrations of calcium ( $K \alpha$ and $K \beta)$.

either isolated or in twins, are in contact with an amorphous substrate believed to be organic in origin.

Spheres of $\mathrm{CaCO}_{3}$ found at the inner surface of adult shells of the freshwater snail, Biomphalaria glabrata, were identified as vaterite by Hasse et al. (2000) using XRD. Our spectra of $x$-ray and FTIR did not confirm this observation, possibly due to the small amounts that are present. Alternatively, the spherical forms found in Physa could represent spherulitic aggregates of calcite.

No explanation is evident for the atypical organization of the nacreous layer in Physa. This structure contrasts with the well-known pattern found in gasteropoda shells (Mutvei 1978, Watabe 1981).

\section{Acknowledgments}

JEOL $840 \mathrm{~A}$ scanning microscope was provided by FINEP/PSME (grant 43.88.0585.00).

S. M. de Paula is recipient of a doctoral fellowship from the Conselho Nacional de Pesquisas Cientificas e Tecnológicas, CNPq (Proc. 140929/2001-0). Thanks to Dr. Valquiria F. J. Kozievitch (Escola Politécnica da USP) for use of the X-ray and FTIR equipments, and to Simone P. de Toledo for excellent technical assistance.

\section{References}

Addadi L, Weiner S: Control and design principles in biological mineralization. Angew Chem Int Ed Engl 31, 153-169 (1992)
Albeck S, Weiner S, Addadi L: Polysaccharides of intracrystalline glycoproteins modulate calcite crystal growth in vitro. Chem Eur $J 2,278-284(1996)$

Birchall JD: The importance of the study of biominerals to materials technology. In Biomineralization. Chemical and Biochenical Perspectives (Eds. Mann S, Webb J, Williams JP). VCH Publ., New York (1989) Chap. 15, 49I-509

Currey JD, Taylor JD: The mechanical behaviour of some molluscan hard tissues. J Zool 173, 395-406 (1974)

Fritz M, Belcher AM, Radmacher M, Walters DA, Hansma PK, Stucky GD, Morse DE, Mann S: Flat pearls-from biofabrication of organized composites on inorganic substrates. Nature 371 , 49-51 (1994)

Hall SR, Taylor PD, Davis SA, Mann S: Electron diffraction studies of the calcareous skeletons of bryozoans. I Inorg Biochem 88 , $410-419(2002)$

Hare PE: Amino acids in the proteins from aragonite and calcite in the shells of Mytilus californianus. Science 139, 216-217 (1963)

Hasse B, Ehrenberg H, Marxsen JC, Becker W, Epple M: Calcium carbonate modifications in the mineralized shell of the freshwater snail Biomphalaria glabrata. Chem Eur J 6, 3679$3685(2000)$

Jones GM, Saleuddin ASM: Cellular mechanisms of periostracum formation in Physa spp. (Mollusca: Pulmonata). Can J Zool 56, 2299-2311 (1978)

Levi-Kalisman Y, Falini G, Addadi L. Weiner S: Structure of the nacreous organic matrix of the bivalve mollusc shell examined in the hydrated state using cryo-TEM. I Siruct Biol 135, 8-17 (2001)

Mann S: Biomineralization and biomimetic materials chemistry. In Biomimetical Materials Chemistry (Ed. Mann S). VCH Printer, NY (1989) Chap. 1: $1-40$

Mann S, Weiner S: Biomineralization: structural questions at all length scales. J Struct Biol 126, 179-181 (1999)

Meldrum FC: Calcium carbonate in biomineralisation and biomimetic chemistry. Int Mater Rev 48, 187-224 (2003)

Mutvei M: Ultrastructural characteristics of the nacre in some Gastropods. Zool Scripta 7: 287-296 (1978)

Saleuddin ASM. Petit HP: The mode of formation and the structure of the periostracum. In The Mollusca Vol 4, Part I, Physiology (Eds. Saleuddin ASM, Wilbur KM). 199-231 Acad Press Inc. (1983) Chapter 5

Simkiss K, Wilbur KM: Molluscs - epithelial control of matrix and minerals. In Biomineralization: Cell Biology of Mineral Deposition. Academic Press, Inc,, San Diego. (1989) Chap. 14, $230-260$

Stupp SI, Braun PV: Molecular manipulation of microstructures: Biomaterials, ceramics, and semiconductors. Science 277. $1242-1248$ (1997)

Watabe N: Crystal growth of calcium carbonate in the Invertebrates Progr Crystal Growth Charact 4, Pergamon Press Ltd., London (1981) 99-147

Watabe N: Shell. In Biology of the Integument, I Invertebrates (Eds. Bereiter-Hahn J, Matoltsy AG, Richards S). Springer-Verlag, Berlin, Heidelberg. NY, Tokyo (1984) Chapter 25: 448-485

White WB: In Infrared Spectra of Minerals (Ed. Farmer VC). Mineralogical Society, London (1974) 227-284

Wilbur K: Shell formation and regeneration. In: Physiology of Mollusca (Eds. Wilbur KM, Yoonge CM). 1, Academic Press, New York, London (1964) Chap. 8: 243-282 


\title{
$1^{\text {st }}$ French-Brazilian Meeting on Polymer - FBPOL 2005
}

\section{Growth of Calcium Carbonate in the Presence of Chitin Extracted from Shrimp}

\author{
S. M. de Paula * and M. Silveira. \\ Instituto de Física, Universidade de São Paulo, 05508-900 São Paulo, Brasil
}

The mechanisms of calcium carbonate crystallization have been studied by among others Addadi et al. ${ }^{1}$. in experiments that mimic mineralizing conditions of hard skeletons and shells by live organisms. Addition of organic biomolecules such as elastin, collagen and chitin were demonstrated to influence both the polymorphism of the carbonate and the morphology of the aggregates formed in vitro ${ }^{2}$.

The aim of the present work was to investigate in vitro the crystallization and growth of calcium carbonate in presence of chitin, extracted in the laboratory from shrimp exoskeletons. These were deproteinized with a solution of $1 \mathrm{M} \mathrm{NaOH}$ for $3 \mathrm{~h}$, then demineralized in $1 \mathrm{M} \mathrm{HCl}$ for $5 \mathrm{~h}$. Following extensive washings in distilled water and drying at room temperature, purity of the chitin was ascertained by FTIR.

The calcium carbonate $\left(\mathrm{CaCO}_{3}\right)$ was obtained by mixing solutions of $\mathrm{CaCl}_{2}(20 \mathrm{mM}), \mathrm{NaHCO}_{3}(20$ $\mathrm{mM})$ and $\mathrm{MgCl}_{2} \cdot 6 \mathrm{H}_{2} \mathrm{O}(40 \mathrm{mM})$. The experiments were performed at $27 \pm 0.5^{\circ} \mathrm{C}$, in a thermostat for 7 days. Chitin was added to the workimg solutions at concentrations of either $10^{-2}$ or $10^{-1} \mathrm{mg} / \mathrm{mL}(\mathrm{pH} 9.0)$. Morphology of the crystals grown under the different experimental conditions were characterized by scanning microscopy (SEM); their polymorphism was investigated by X-ray diffraction (XRD)

The XRD- spectra, using the Rietveld refinement, have clearly demonstrated that chitin influences the polymorphism of calcium carbonate crystals. In control experiments, without additives, only aragonite crystals were formed (refinement index $\mathrm{S}=1.23$ ). Following addition of chitin at $10^{-2} \mathrm{mg} / \mathrm{mL}$, one obtains 87 $\%$ aragonite and $13 \%$ calcite $(\mathrm{S}=1.28)$. For the higher concentration used, $10^{-1} \mathrm{mg} / \mathrm{mL}$, only calcite crystallizes (with $\mathrm{S}=1.32$ ). (Fig. $1 \mathrm{~A})$.

SEM investigations show that the aragonite formed in control solutions has spherulitic morphology. In the presence of chitin, for both concentrations essayed, the calcite occurs as aggregates of elongate prisms (Fig.1B). These results suggest that both morphology and polymorphism of calcium carbonate can be controlled in bio-systems by chitin, a natural, polymeric molecule present in the organic matrix.
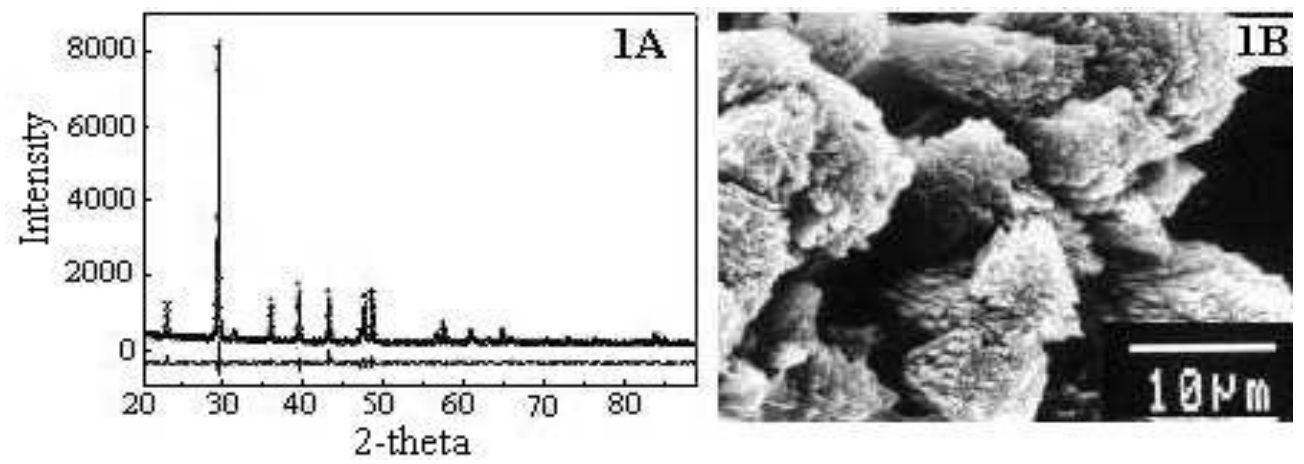

\section{References}

${ }^{1}$ Addadi, L.; Weiner, S; Geva, M. Z. Kardiol 2001, 90: Suppl. 3, 92-98.

${ }^{2}$ Mikkelsen, A.; Engelsen, S.B.; Hansen, H.C.B.; Larsen, O.; Skibsted,L.H.J. Crystal Growth 1997, 177, 125-134

\section{Acknowledgements}

*CNPq fellow, Proc. 140929/2001-0. SEM provided by FINEP/PSME (\#43.88.0585.00). We thank Antonio Carlos Franco da Silveira (LCr-IFUSP) for processing the XRD spectra.

*Presenting author: sipaula@if.usp.br 


\title{
Brazilian Journal of Morphological Sciences, suplemento, p. 70-71, 2005. XX Congress of Brazilian Society for Microscopy and Microanalysis
}

\section{CALCIUM CARBONATE GROWTH IN PRESENCE OF A BIOLOGICALORGANIC ADDITIVE}

\author{
de Paula, S. M."; Alexiou, A.D.P. ${ }^{2}$; Toma, H.E.; ; Silveira, M. \\ "'Electron Microscopy Laboratory, Physics Institute, University of São Paulo, Brazil'Chemistry Institute, \\ University of Sao Paulo, Brazil \\ sipaula@if.usp.br and msilveir@if.usp.br
}

Many organisms including molluscs [1,2] and corals [3] are able to synthesize a variety of crystalline materials, whose physical properties are somehow controlled by lipids, polysaccharides and proteins present in an organic matrix $[4,5]$. The phenomena involved in the biocomposite's deposition is of much interest, for the final product exhibits a characteristic architecture, combined with mechanical strength [6], specific crystallographic orientation and controlled dimensions [7].

The aim of the present work was to investigate in vitro the influence of the organic matrix extracted from shells of the pulmonate snail Physa sp. (Mollusca, Gasteropoda), upon growth of calcium carbonate. The calcareous shell of this organism is highly structured, and contains calcium carbonate crystals with different morphologies [8].

The insoluble organic matrix was isolated from shells fully demineralized in $1 \mathrm{~N} \mathrm{HCl}$ and washed with distilled water. This solution was then centrifuged, and extensively dialyzed; the insoluble precipitate was collected and dried at room temperature.

A calcium carbonate solution was prepared by mixing equal volumes of $\mathrm{CaCl}_{2}(20 \mathrm{mM})$ and $\mathrm{NaHCO}_{3}$ $(20 \mathrm{mM})$ in a thermostate controlled bath at $27 \pm 0,5^{\circ} \mathrm{C}$, for 7 days. The insoluble organic extract was added to the workimg solution at concentrations of $10^{-2}$ and $10^{-1} \mathrm{mg} / \mathrm{mL}$. Aliquots of the workimg solution were allowed to crystallize without any additive.

At the end of the experiments the crystals were washed with distilled water, dried at room temperature and examined by scanning microscopy (SEM), by X-Ray diffraction and by infrared spectroscopy (FTIR).

The FTIR spectra demonstrate that addition of the organic matrix induces only slight modifications on the polymorphism of calcium carbonate crystals (Fig.1), as also confirmed by XRD data, refined by the Rietveld method. In control batches, the yield was $96.97 \%$ calcite and $3.03 \%$ vaterite. Following addition of organic matrix only calcite crystals with a (104) preferential orientation were observed (Fig.2).

As shown in Figure 3, crystals grown in the control solution have a characteristic rhombohedral habitus; in contrast, SEM images of calcium carbonate polymorph crystals grown in presence of the organic matrix extract, were mostly spherical (Fig. 4) including just a few rhombohedra (Fig. 5).

In conclusion, it can be said that the organic matrix extracted from shells of Physa induces in vitro the crystallization of spherical calcite. Despite the several morphologies obtained, polymorphism of the calcium carbonate has been preserved: in both cases the calcite occurred in high quantities.

Acknowledgements: *CNPq doctoral fellowship (Proc.140929/2001-0). SEM provided by FINEP/PSME (\#43.88.0585.00). We thank Antonio Carlos Franco da Silveira (LCr-IFUSP) for processing the XRD spectra and Simone P. de Toledo for technical assistance.

\section{References:}

[1] F. Marin, G. Luquet, C.R. Palevol 3 (2004) 469-492.

[2] M. Rousseau, E. Lopez et al, J. of Structural Biology 149 (2005) 149-157.

[3] Y. Dauphin, Intern. J. of Biological Macromolecules 28 (2001) 293-304

[4] G. Falini, S. Albeck,S. Weiner and L. Addadi, Science 271 (1996) 67-69.

[5] J. Aizenberg, J. Hanson, T.F. Koetzle, S. Weiner and L. Addadi, J. Am. Chem. Soc. 119 (1997) 881-886.

[6] J.D. Currey, J. Zool. 173 (1974) 395-406

[7] Q.L. Feng et al, J. of Crystal Growth 216 (2000) 459-465

[8] S. M. de Paula, M. Silveira, Applied Mineralogy Vol 1 (2004) 183-186 


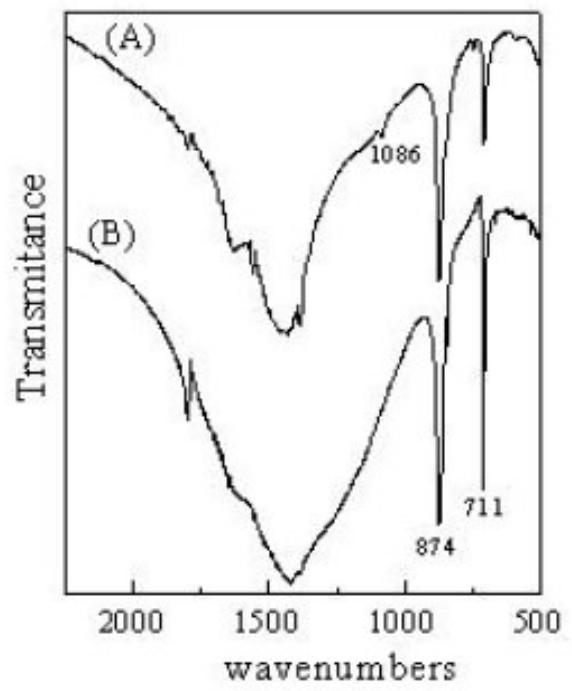

Figure 1 - FTIR spectra. (A) control solution of $\mathrm{CaCO}_{3 .}$ (B) calcite grown in presence of the organic matrix.

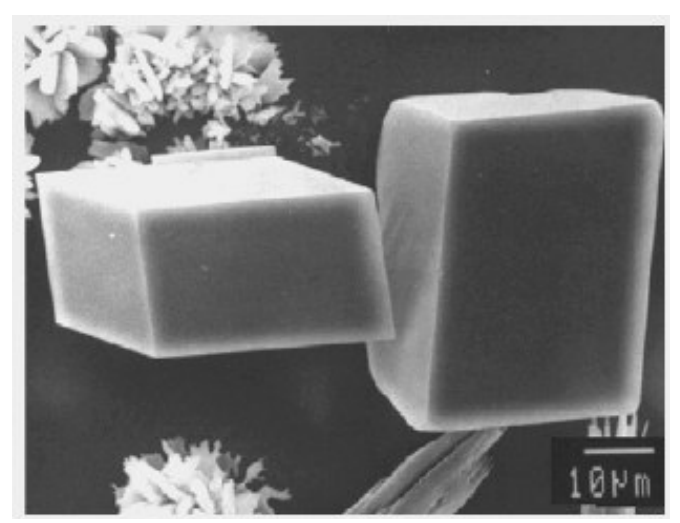

Figure 3 - Synthetic calcite crystals grown in the control solution of $\mathrm{CaCO}_{3}$. X 900

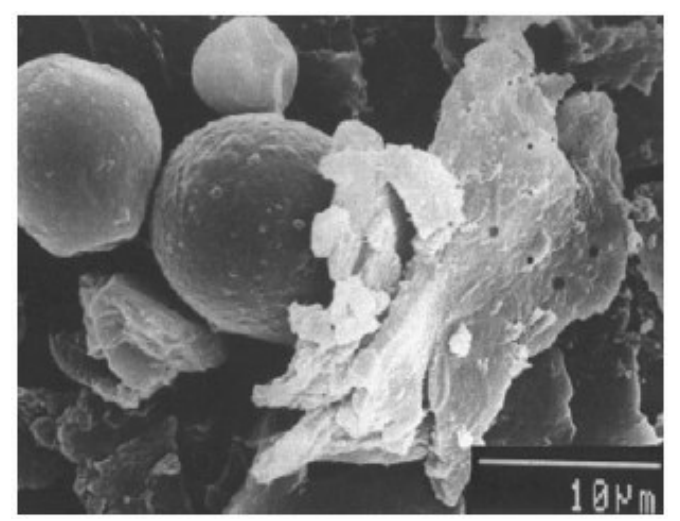

Figure 4 - Spherical calcite crystals grown in presence of the organic matrix. X 2300
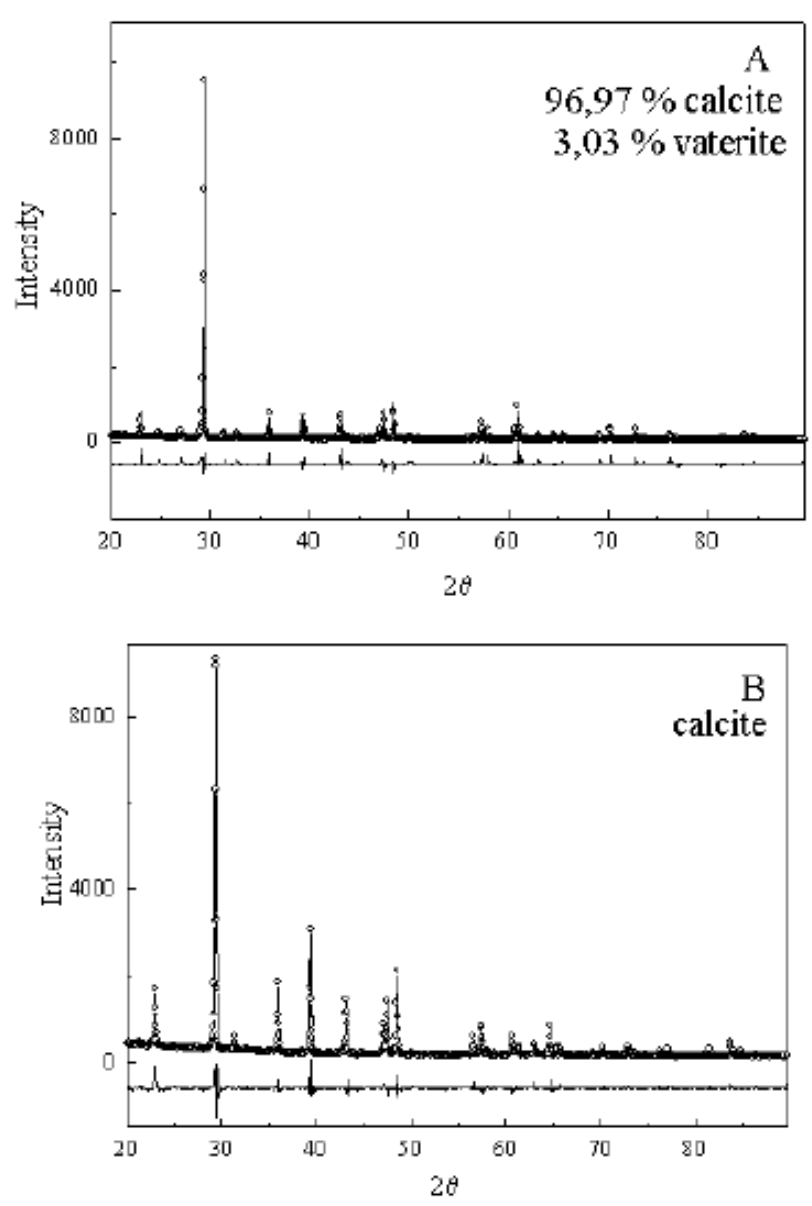

Figures 2A, B - Rietveld refinement demonstrating the effects of organic matrix addition upon polymorphism of $\mathrm{CaCO}_{3}$ crystals. The circle graphics are experimental data; straight graph, the simulated pattern and the straight lower graph, the difference pattern (experimental minus calculated).

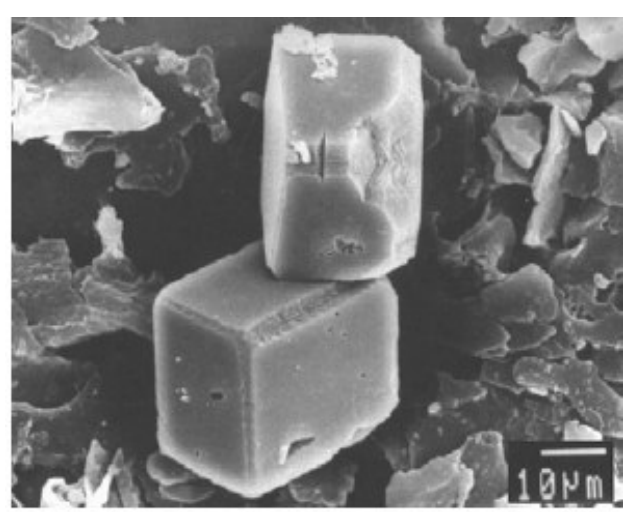

Figure 5- Rhombohedral calcite crystallized In presence of the organic matrix. X 900 
Developments in Science and Technology - Applied Mineralogy, v.1, p. 183-186, 2004

International Council for Applied Mineralogy do Brasil, ICAM-BR, 2004

\author{
Calcium carbonate polymorphism in shells of the mollusc Physa sp. \\ S. M. de Paula \& M. Silveira \\ Electron Microscopy Laboratory, Physics Institute, University of Sao Paulo, Sao Paulo, Brazil
}

\begin{abstract}
The complex process of biomineralization is being studied with increasing interest recently, regarding the possibility of devising new materials for technological applications. Nature provides many mineralizing organisms, that produce inorganic deposits with hard and complex structures (Addadi \& Weiner 1997). Mollusc shells have a complex microstructure as a result of an organized arrangement of crystals, grown upon an organic matrix. Different crystals of $\mathrm{CaCO}_{3}$ are deposited along different sites on the inner surface during growth of the shell. They occur mostly as calcite and/or aragonite (Watabe 1984), and to a lesser extent as vaterite polymorphs (Kato 2000, Lowenstam 1981). In this work we have investigated by scanning electron microscopy the calcium carbonate polymorphism in shells of the freshwater mollusc Physa sp. (Gasteropoda) ranging in size from $0,5 \mathrm{~mm}$ to $10 \mathrm{~mm}$. Crystals with different habits occur in the several sites examined: rhombohedra, hexagonal plates and prisms, in addition to spherulitic and disk-shaped crystals. All these different crystal habits were found in regions near the apex; spherulites occur in the inner surface of the apex itself, whereas in the juvenile Physa sp. $(0,5 \mathrm{~mm})$ only the circular units were observed so far on their outer surface. The mineral phases were analysed by X-Ray diffraction and the data refined with the Rietveld method, and by Fourier transform infrared spectroscopy (FTIR), demonstrating the presence of only aragonite.
\end{abstract}

\section{INTRODUCTION}

Biomineralization is a common process in nature, through which the organisms convert ions in solution into solid minerals (Simkiss \& Wilbur 1989). Mineralizing organisms are able to synthesize a variety of biominerals with different habits, the calcium carbonate being the most abundant one (Sikes \& Wheeler 1988): it occurs as calcite, aragonite and vaterite (Falini et al. 1996).

In this work we have investigated some aspects of the biomineralization process in shells of the mollusc Physa sp. This organism provides an interesting system for such studies for it is able to build arrangements of calcium carbonate crystals that grow quite rapidly.

The crystal regularity, orientation and mechanical properties of mollusc shells bear an intimate relation to organic matrix (Addadi \& Weiner 1997), known to contain aminoacids, proteins and polysaccharides (Weiner 1979).

\section{MATERIALS AND METHODS}

The pulmonate freshwater Physa sp. is a mollusc of the Class Gasteropoda. The shell has the shape of a cone (Rhoads \& Lutz 1980) about 10-15 mm wide.

Animals raised in small aquaria at about $26^{\circ} \mathrm{C}$ were used throughout the present work.

To investigate the mineral phase, shell fragments were ground in a mortar, the resulting powder was passed through a 200 mesh sieve and analyzed by X-Ray (powder method) using an X-pert MPD Philips diffractometer. The data were collected in

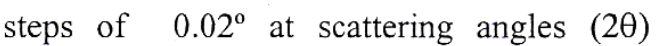
ranging from 20 to $90^{\circ}$. The FTIR analyses were performed with a Nicolet 560 FTIR spectrometer and were recorded at $4 \mathrm{~cm}^{-1}$ resolution. The powder was included in $\mathrm{KBr}$ pellets for these essays.

For scanning electron microscopy (SEM), shells between $0,5-10 \mathrm{~mm}$ in height were carefully removed from the mollusc and washed in distilled water for 12 hours; shells larger than $2 \mathrm{~mm}$ in length were cleaned with 
$40 \% \mathrm{NaClO}$ (sodium hypochloride) solution for $24 \mathrm{~h}$ to removed the organic matter.

Partly decalcified samples were prepared by use of either 2\% EDTA (ethhylenediamine tetraacetic acid) or 1 mol. $\mathrm{L}^{-1} \mathrm{HCl}$.

All samples were dried at room temperature for $12 \mathrm{~h}$, mounted on the stub with silver paste and gold-sputtered for morphological studies with the Jeol JSM 840A electron microscope, operated at 12,15 or $25 \mathrm{kV}$.

\section{RESULTS}

Our X-ray diffraction results indicate high crystallinity for the calcium carbonate; the Rietveld refinement showed the presence of only aragonite (Figure 1). Infrared spectra also confirm peaks characteristic for aragonite (Figure 2).

Scanning electron microscope studies presented interesting structures in the shells.

Shells in the initial stages of development showed an arrangement of circular units, about 1,6 $\mu \mathrm{m}$ in diameter (Figure 3) all along their external surface.

Shells ranging between $5-9 \mathrm{~mm}$ in height showed in the apex many spheres about $1 \mu \mathrm{m}$ or less (Figure 4).

Crystals exhibiting a greater variety of forms and habits occur along the columella (Figure 5) and near the apex (Figures 6,7).

Another regular, characteristic array crystals occurs in the inner surface near the aperture of the shell (Figure 8).

\section{DISCUSSION}

Mollusc shells are an excellent system to study the biomineralization process once these organisms provide crystals of calcium carbonate with interesting organization and great variations in their crystalline habits .

Different types of crystals are deposited at the same time in diverse parts of the shell. Crystals near the shell edge may be elongate, whereas in central regions of the shell tabular forms are found (Simkiss \& Wilbur 1989). mineral phase of the shell of Physa sp. was followed from its initial stages, when the shells were about $0,5 \mathrm{~mm}$. Only plates of aragonite were present, but no other crystalline
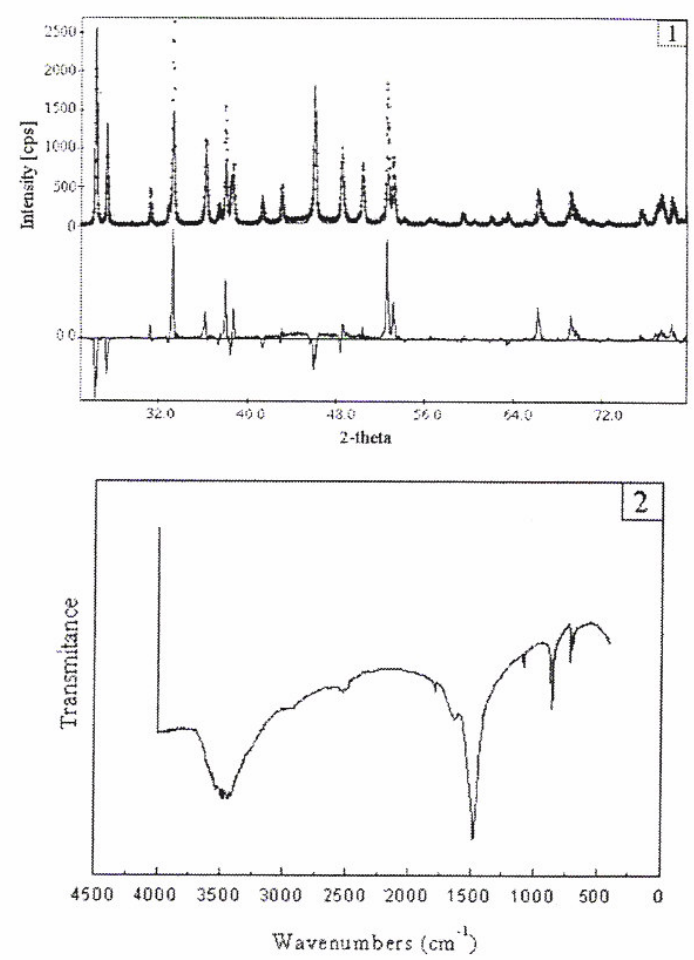

Fig.1 - Rietveld refinement of diffraction pattern of the shell of Physa sp., demonstring the typical spectrum of aragonite.

Fig.2- Infrared spectrum showing peaks characteristics of aragonite.

polymorphs.

Spheres of calcium carbonate, probably vaterite, were found only in the apex; our

$\mathrm{X}$-ray diffraction and the infrared spectra data could not yet confirm this identification, because they occur in very small amount. This crystalline form was found in the apex of mollusc shells for several other authors in which small amounts of vaterite were detectable with

synchrotron X-ray diffraction (Hasse et al. 2000 ).

In some other molluscs prisms originate in spherulites that develop on the inner surface of the newly formed sheet of periostracum (Taylor \& Kennedy 1969). 

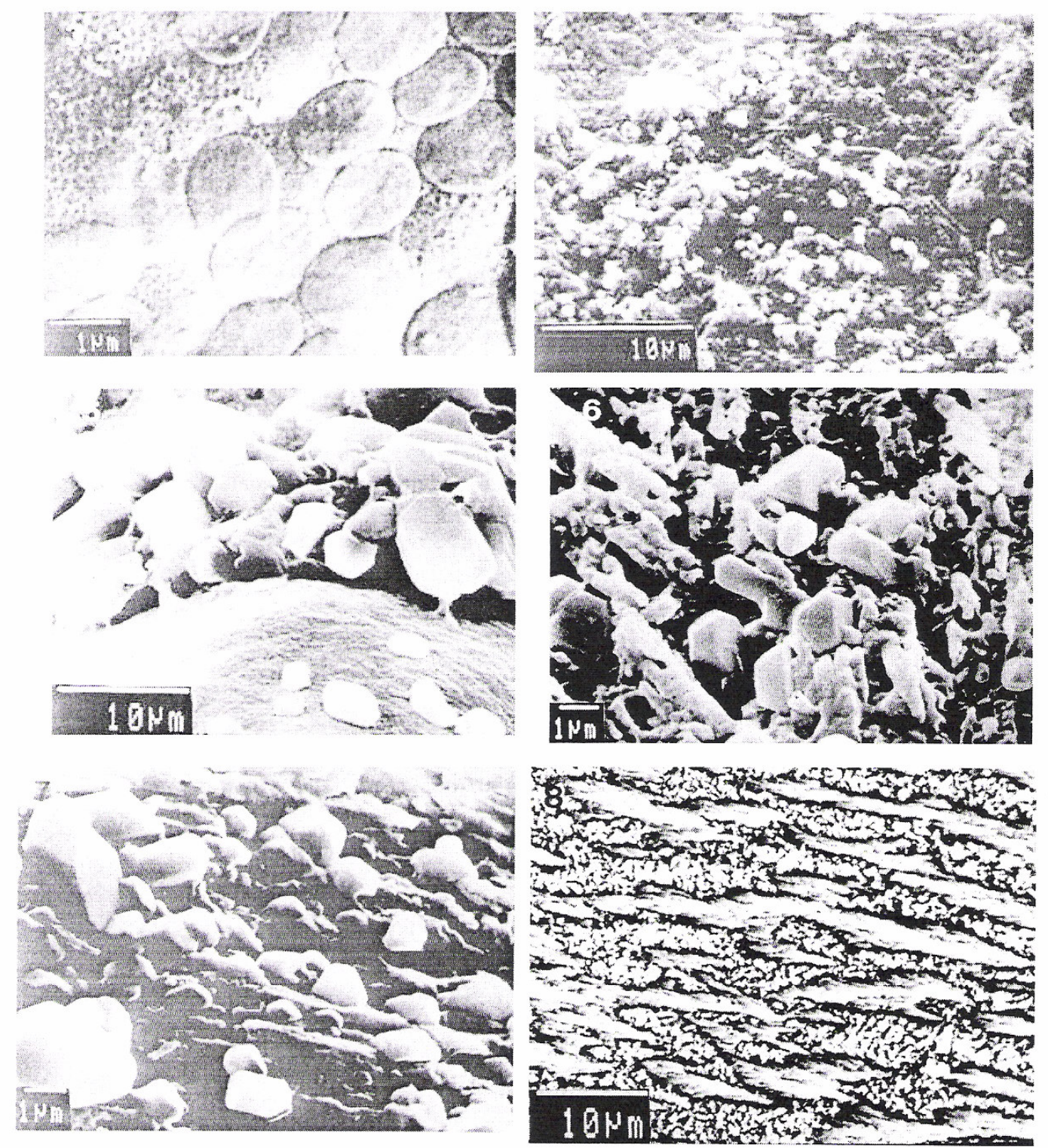

Fig.3 - Arrangement of the circular units covering the external surface of a shell, washed in distilled water. $\times 15,000$

Fig.4 - Spheres of calcium carbonate. Shell eroded with 2\% EDTA for $1.5 \mathrm{~min}$. x 2800

Fig. 5- Aragonite crystals found in the columella. x 1800

Fig. 6 and 7 - Crystals with the most different habits. Shell cleaned in $\mathrm{NaOCl}$ for 24 h. $\times 7500$

Fig. 8 - Bundles of prisms oriented into two axes cover the inner surface of the shell, near its opening. Etched with 1 mol. $\mathrm{L}^{-1} \mathrm{HCl}$ for $5 \mathrm{~min}$. $\mathrm{x} 1600$ 
We found prismatic aggregates with a relatively uniform orientation in the inner surface of the Physa sp. The orientation of the prisms is relatively constant for every shell of a same species, and characteristic for the species (Boggild in Watabe 1984).

In our material, both X-ray diffraction and the infrared spectra demonstrate that aragonite is the main inorganic phase. So far, we have no information about the organic composition of this shell.

We could demonstrate here, several polymorphs in different sites of the shells. The mechanisms by which crystal polymorphism occurs are not well understood, but the crystal growth is known to keep an intimate linkage with the organic matrix. Factors as temperature and salinity also influence crystalline habits.

Many aspects of the biomineralization process are still needed, including in vitro and in vivo studies for clarifying the formation mechanism of mineralized materials.

\section{ACKONOWLEDGEMENTS}

CNPq fellowship (process 140929/2001-0).

We would like to express our thank to Valquíria de Fátima Justo Kozievitch (Escola Politécnica - USP) for the XRD and Astrogildo de Carvalho Junqueira (Instituto de Pesquisas Energéticas e Nucleares- IPEN) for discussion about Rietveld Method.

\section{REFERENCES}

Addadi, L \& Weiner, S 1997. A pavement of pearl. Nature

389: 912-915.

Falini et al. 1996. Control of aragonite or calcite polymorphism by mollusk shell macromolecules. Science 271: 67-69.

Hasse B. et al. 2000. Calcium carbonate modifications in the mineralized shell of the freshwater snail Biomphalaria glabrata. Chem. Eur. J. 6: 3679-3685.

Kato, T. 2000. Polymer/calcium carbonate layered thin-film composites. Advanced Materials 12: 1543-1546.

Lowenstam, H A 1981. Minerals formed by organisms. Science 211: 1126-1131.

Rhoads, D.C. \& Lutz, R. A. 1980. Skeletal Growth of Aquatic Organisms. New York Plenum Press

Sikes, C.S. \& Wheeler, P. 1988. Regulators of biomineralization. Chem Tech. 18 (ISS 10): 620-626.

Simkiss, K \& Wilbur, K.M. 1989. Biomineralization - Cell Biology and Mineral Deposition. City:Publisher San Diego, Academic Press, Inc.

Taylor, J. \& Kennedy, W.J. 1969. The influence of the periostracum in shell structure of bivalve molluscs. Calc. Tissue Res. 3 : 274283

Watabe, N ( Bereiter-Hahn J. ; Matoltsy A. G. and Richards, K. S. eds) 1984. Biology of the integument - I Invertebrates . SpringerVerlag Berlin.

Weiner, S. 1979. Aspartic Acid-Rich Proteins: Major Components of the soluble Organic Matrix of Mollusk Shells. Calc. Tissue Int. 29: 163-167. 


\title{
XII Brazilian Meeting on Inorganic Chemistry and Joint Brazilian/Italian Meeting on Inorganic, 2004.
}

\section{GROWTH OF CALCIUM CARBONATE IN THE PRESENCE OF ASPARTIC ACID}

\author{
S.M. de Paula and M. Silveira. \\ Universidade de São Paulo - Instituto de Física - LME \\ R. do Matão, travessa R, 187, São Paulo \\ sipaula@if.usp.br and msilveira@if.usp
}

In Nature many organisms synthesize calcium carbonate with a high variety of crystalline habits. The growth and polymorphism of the $\mathrm{CaCO} 3$ is affected by several macromolecules including acidic proteins present in their organic matrix [1].

The aim of the present work is to investigate in vitro the growth of calcium carbonate crystals in the presence of aspartic acid at different concentration.

The calcium carbonate solution was prepared by mixing equal volumes of $\mathrm{CaCl} 2(20 \mathrm{mM})$, $\mathrm{NaHCO} 3(20 \mathrm{mM})$ and $\mathrm{MgCl} 2.6 \mathrm{H} 2 \mathrm{O}(40 \mathrm{mM})$. The experiments were performed in a thermostate controlled bath at $27 \pm 0,5^{\circ} \mathrm{C}$ for 7 days. Aspartic acid (Aldrich), in different concentration (10-3, 10$2,10-1 \mathrm{mg} / \mathrm{ml}$ ), was added to the workimg solution. At the end of the experiments the crystals were examined by scanning microscopy (SEM), their polymorphism being investigated by infrared spectroscopy (FTIR).

Fig.1 exhibits the absorption characteristic for aragonite. The SEM results (Fig.2) show the effect of the additive on the crystallization of aragonite: the amount of formed crystals decreases for increasing concentration of aspartic acid (Figs.2 B,C, D) in relation to the control preparation (Fig.2A), therefore demonstrating its inhibitory effect. Spherulitic aggregates of aragonite are frequently obtained (Fig.3).
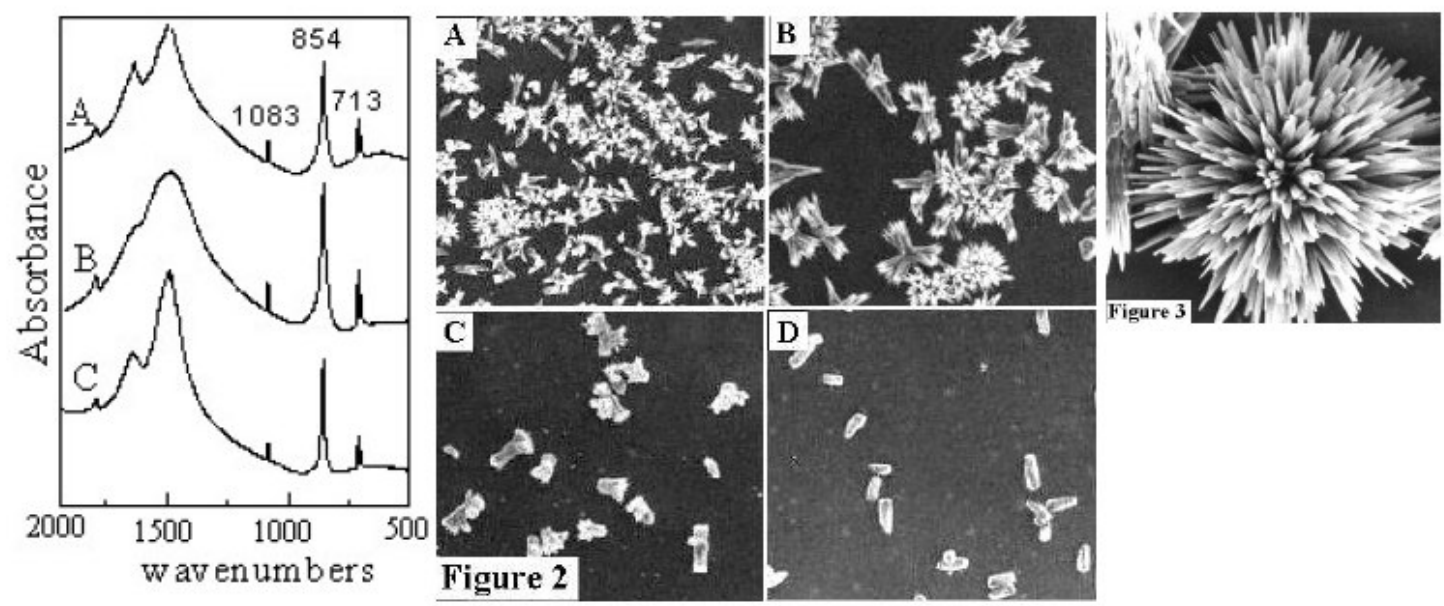

\section{References}

[1] L. Addadi, S. Weiner and M.Geva. Z. Kardiol 90: Suppl 3 (2001) , III92-98.

\section{Acknowledgements}

CNPq fellowship, process 140929/2001-0. 
Acta Microscopica, Volume 12, Supplement B, September 2003

XIX Congress of the Brazilian Society for Microscopy and Microanalysis

\title{
CORRELATION BETWEEN MOLLUSC SHELL LENGTH AND CALCIUM CARBONATE POLYMORPHISM
}

\author{
de Paula, S.M.; Silveira, M. \\ Laboratório de Microscopia Eletrônica - Departamento de Física Geral, Instituto de Física da USP, \\ C.P.66318 - 005315-970, São Paulo, SP, Brasil \\ sipaula@if.usp.br \\ msilveir@if.usp.br
}

Calcium carbonate is the most abundant mineral formed by Nature and it occurs in more than 40 different types of living systems [1]. Mollusc calcareous shells (calcareous) have a complex microstructure as a result of an intimate linkage of crystals grown upon an organic matrix. This matrix assumes an important role in the mineralization process [2]. In mollusc shells, different types of $\mathrm{CaCO}_{3}$ crystals are deposited along different sites on its inner surface during growth. Calcium carbonate polymorphs occur mostly as calcite and / or aragonite, and to a lesser extent as vaterite [3] .

The present work attempts to correlate the mineral deposits found in the shells of the freshwater mollusk Physa sp. (grown in the laboratory) both with their developmental stages ranging in size between 0,5 - $10 \mathrm{~mm}$ and also with their location within the shell. Adult Physa shells reach $10 \mathrm{~mm}$ in length. The shells were carefully isolated from the molluscs and washed in water for $24 \mathrm{~h}$. The organic matter was

removed in $40 \% \mathrm{NaClO}$ (sodium hypochloride) for $12 \mathrm{~h}$, followed by distilled water washings for $12 \mathrm{~h}$. The samples were dehydrated in $97 \%$ ethanol and allowed to dry on to filter paper for $24 \mathrm{~h}$. Some shells were chemically etched with $0,1 \mathrm{~N} \mathrm{HCl}$ for $10 \mathrm{~min}$. Others were dried and eroded in a Oxygen plasma for $30 \mathrm{~min}$. (Plasmaprep II). All the samples were gold-sputtered and studied in the Jeol JSM 840-A electron microscope, operated at 12 or $25 \mathrm{kV}$.

For identification of the mineral phases, shells were mechanically ground in a mortar, passed through a 200 mesh sieve and analyzed by X-Ray (powder method) using an X-pert MPD Philips diffractometer. The data were collected in steps of $0.02^{\circ}$ at scattering angles (20) ranging from 20 to $90^{\circ}$. The XRD curve refined with the Rietveld method showed the presence of only aragonite (Fig. 5). Qualitative elemental analysis was performed on carbon coated samples, using a Jeol JSM 840-A at $25 \mathrm{kV}$, equipped with a EDS system (fig. 4). We have found that young mollusc shells up to $0,5-3,0 \mathrm{~mm}$ in length are covered on their external surface by an aragonite layer [4]. It shows a plate-like arrangement of circular units, about 1,6 $\mu \mathrm{m}$ in diameter (Fig. 1). Crystals having different crystallographic habits were observed in shells ranging from 3-8 mm (Fig. 2). In the oldest part (apex) of shells ranging between 5-9 mm in length, many spherulitic deposits about $1 \mu \mathrm{m}$ in diameter were found, that very likely correspond to vaterite [5-6] (Fig.3).

\section{Acknowledgements:}

CNPq fellowship (process 140929/2001-0).

We thank Valquíria de Fátima Justo Kozievitch (Escola Politécnica - USP) for the XRD, Astrogildo de Carvalho Junqueira (Instituto de Pesquisas Energéticas e Nucleares - IPEN) and Prof. Dr Artur Wilson Carbonari (Instituto de Pesquisas Energéticas e Nucleares - IPEN) for discussions about de Rietveld method.

\section{References:}

[1] C. S. Sikes and A.P. Wheeler, Chem Tech (1988) 620-626

[2] N. Watabe in Biology of the Integument - 1 Invertebrates (Bereiter-Hahn, J.; Matoltsy, A.G. and Richards, S., eds), 1984 - Chapter 25

[3] T. Kato, Advanced Materials 12 (2000) 1543-1546

[4] N. Watabe and H.K. Erben, Nature 248 (1974) 128-130.

[5] K. Naka And Y.Chujo, Chem. Mater. 13 (2001) 3245-3259.

[6] B. Hasse, H. Ehrenberg, J.C. Marxen, W. Becker and M. Epple, Chem. Eur. 20 (2000) 3679-3685. 
Acta Microscopica, Volume 12, Supplement B, September 2003 $X I X$ Congress of the Brazilian Society for Microscopy and Microanalysis

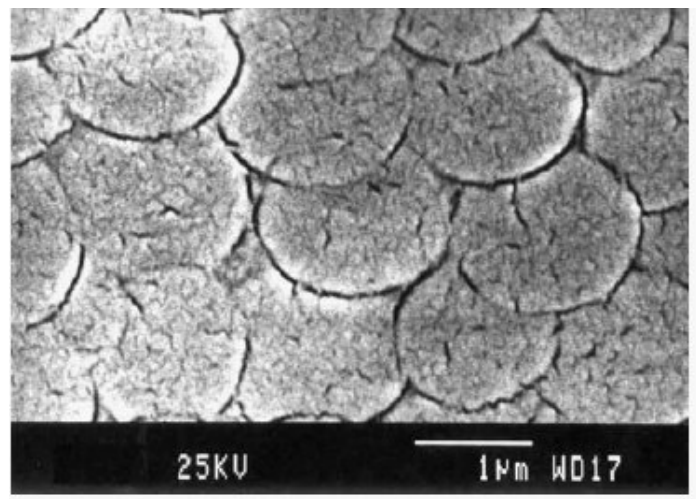

Figure 1- Aragonite lamina covering the external surface of a shell with $2 \mathrm{~mm}$ length. Washed in distilled water for $24 \mathrm{~h}$ and dried on the filter paper at room temperature. X 20000

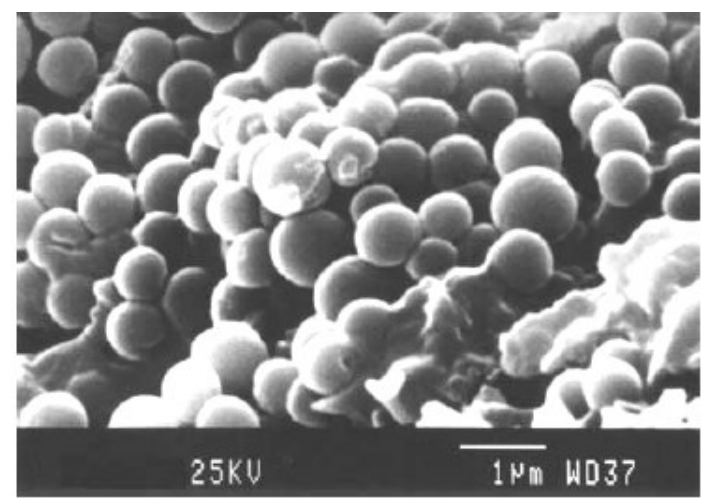

Figure 3 - Sphers of $\mathrm{CaCO}_{3}$, identified as vaterite, present in the inner surface of the apex. Oxygen etching (30 min). X 15000

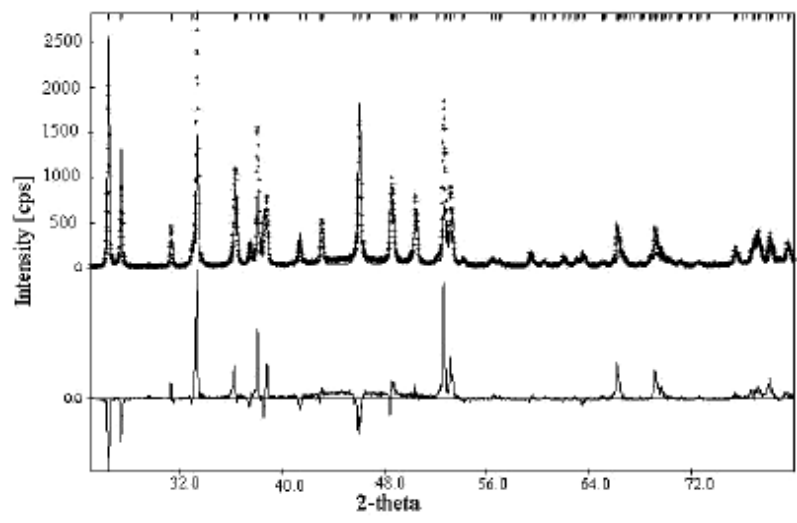

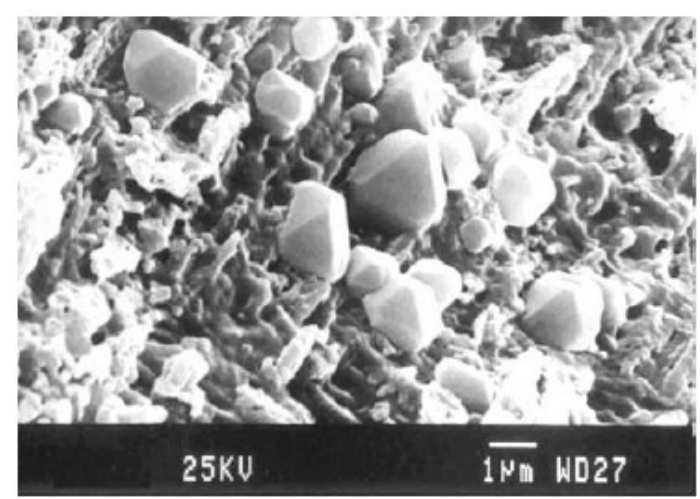

Figure 2 - Aragonite crystals with different habits, present in many sites at the inner surface of shells ranging from 3-8 $\mathrm{mm}$ length. Etched with $0,1 \mathrm{~N} \mathrm{HCl}$ for $10 \min$ X 8000

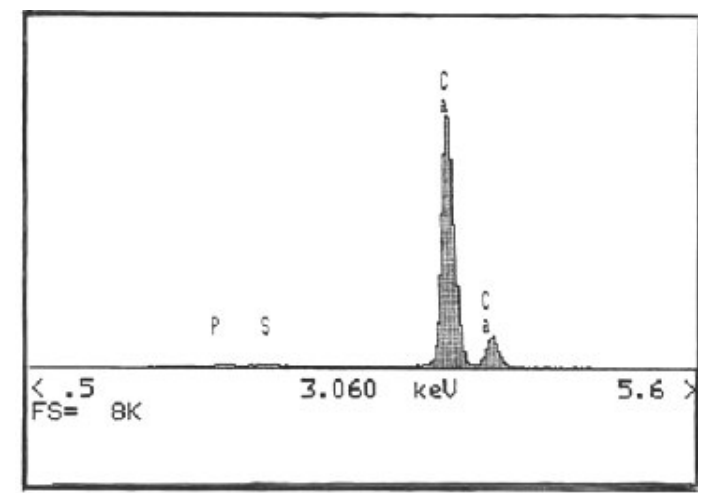

Figure 4 - EDS spectrum of shells washed only in distilled water for $24 \mathrm{~h}$. Note the high peaks of calcium $(\mathrm{K} \alpha$ and $\mathrm{K} \beta$ )

Figure 5 - X-Ray powder diffraction spectrum of aragonite, from Physa shells. Data refined with the Rietveld method. 


\title{
BIOMINERALIZATION IN MOLLUSCS
}

\author{
de Paula, S.M,; Silveira, M. \\ ${ }^{(1)}$ Laboratório de Microscopia Eletrônica - Departamento de Física Geral, Instituto de Física da \\ USP, C.P.66318 - 005315-970, São Paulo, SP, Brasil
}

Biomineralization refers to the process through which living organisms control the nucleation of minerals within or outside their bodies. Examples of such materials are bones, teeth, shells and many others. Biomineralizing organisms can produce inorganic deposits, usually having high resistance and a complex organization, as is the case of some Molluscan shells. Mollusc shells have at least seven grossly different types of complex architecture [1], being mainly composed of calcium carbonate crystals in the form of calcite and/or aragonite [2]. The source of the inorganic ions involved, the remarkable regularity of the final product and the involvement of an organic matrix are points of the process still incompletely solved.

We have chosen the freshwater gastropod, Physa sp., that can be reared in small aquaria in the laboratory, as a model for investigating the biomineralization process. For the present experiments, shells ranging from 1-9 mm in length were selected for a initial characterization, using scanning electron microscopy. After cleaning in distilled water, the organisms were narcotized overnight with $\mathrm{MgCl}_{2}$ solution, then freed from the shells; the empty shells were further cleaned in $40 \%$ sodium hypochloride solution, washed again in distilled water, dehydrated in ethanol and allowed to dry at room temperature for $12 \mathrm{~h}$. or longer. Whole shells or small fragments of them, cut with a scalpel, were gold-sputtered and studied in the Jeol JSM 840-A electron microscope, operated at 10, 12 or $25 \mathrm{kV}$.

Shells of Physa (Fig.1) have an overall smooth outer surface, with a thickened oral aperture; the first gyres of the shell (columella) are covered with hexagonal, plate-like crystals of calcium carbonate, grown in a single layer (Fig.2 ); prismatic crystals were observed along fractured surfaces, in which case they are oriented at $30^{\circ}$ along consecutive layers (Fig.3 ). In specimens etched with 2\% EDTA for two minutes, many parallel growth lines were observed in the columella, spaced at about 13,6 $\mu \mathrm{m}$ intervals (Fig.4).

AKNOWLEDGEMENTS:

CNPq supported this work, process 140929/2001-0 


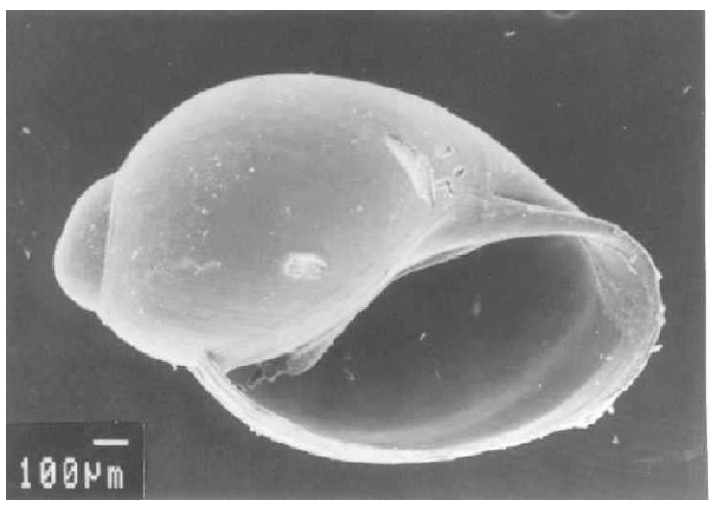

Fig. 1 Whole, empty shell of Physa, exhibiting a smooth surface. X 50

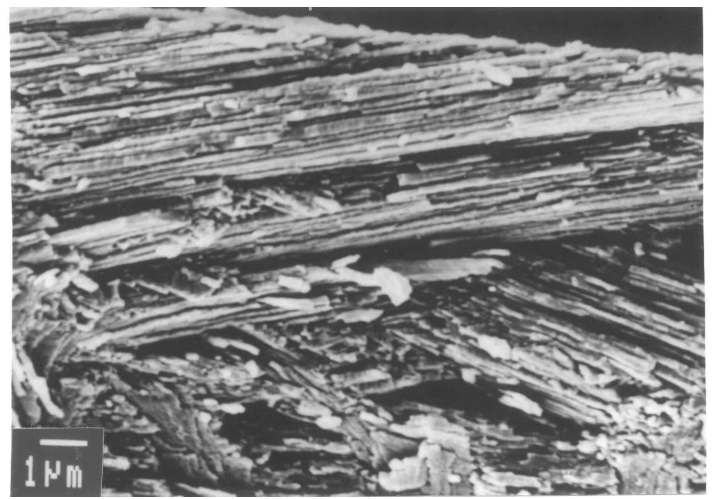

Fig. 3 Fracture surface through the shell, showing the prismatic layers next to the apical border. X 5000

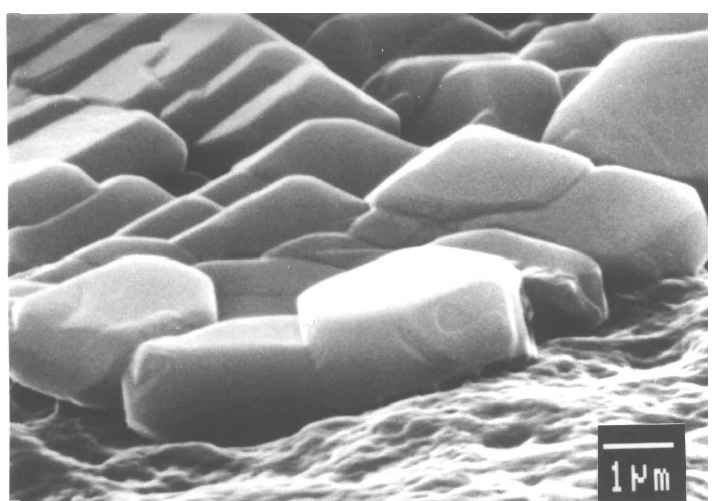

Fig.2 Plates of the $\mathrm{CaCO}_{3}$ present in the inner surface, next to the apex. X 10000

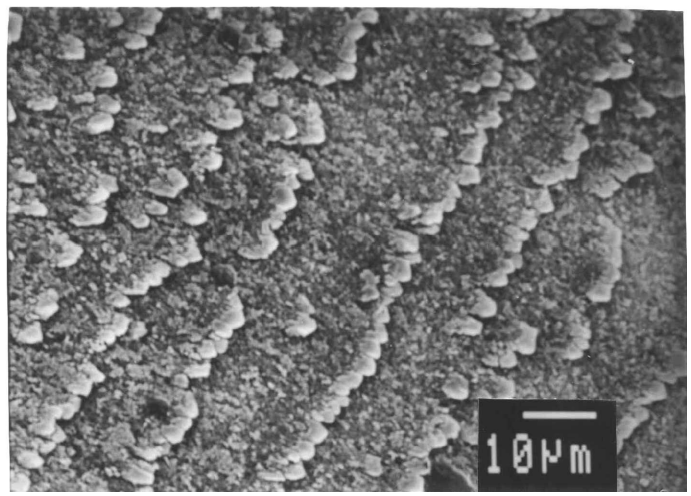

Fig. 4 Growth lines showing a good parallelism at the outer surface of the columela. Preparation etched with $2 \%$ EDTA following cleaning. X 800 